Prepared in cooperation with Los Alamos National Laboratory and the City of Santa Fe, New Mexico

\title{
Ground-Water Temperature, Noble Gas, and Carbon Isotope Data from the Española Basin, New Mexico
}

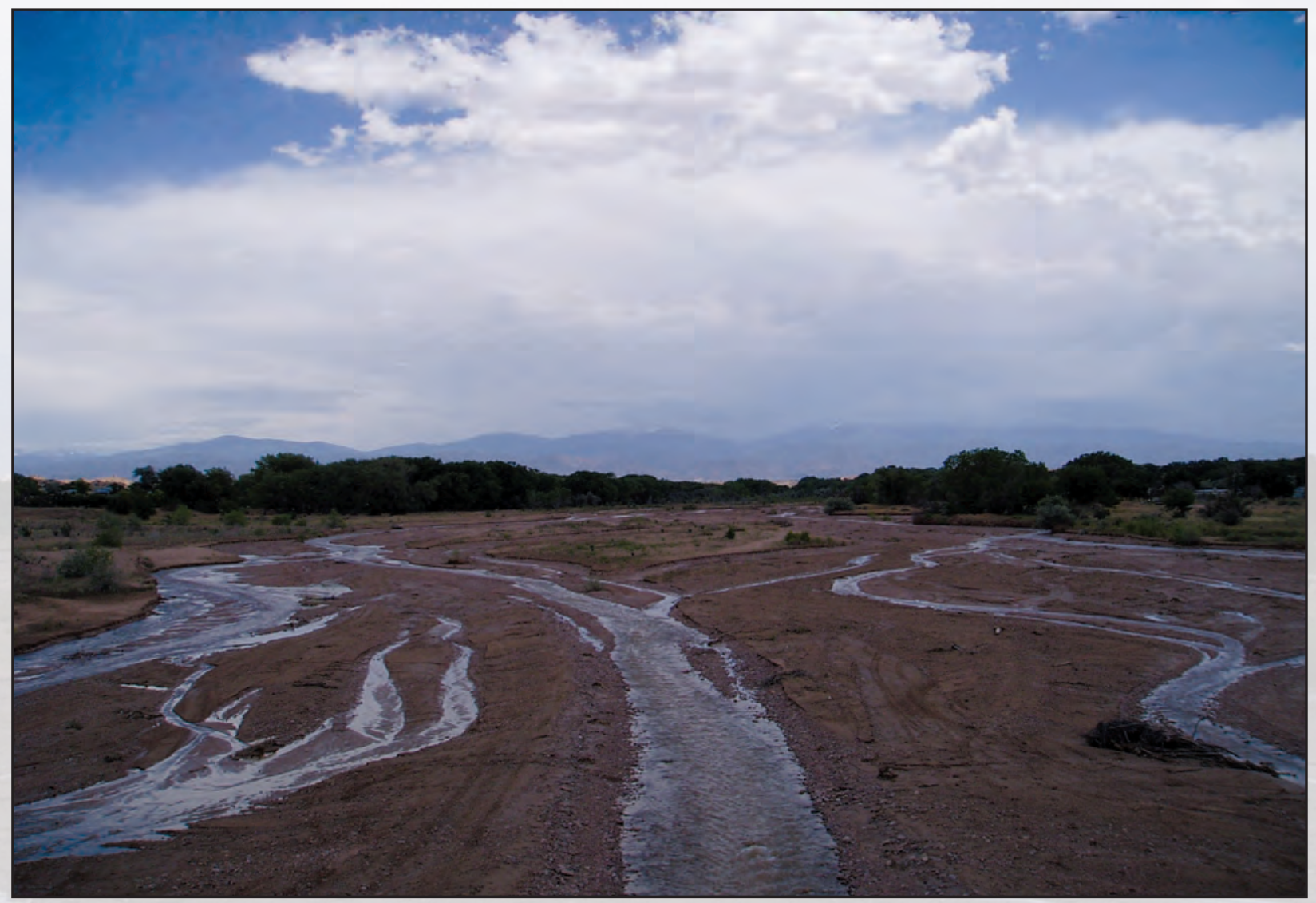

Scientific Investigations Report 2008-5200 
COVER: View of the Pojoaque River looking east with the Sangre de Cristo Mountains in the background. Photograph by Andrew H. Manning. 


\section{Ground-Water Temperature, Noble Gas, and Carbon Isotope Data from the Española Basin, New Mexico}

By Andrew H. Manning

Prepared in cooperation with Los Alamos National Laboratory and the City of Santa Fe, New Mexico

Scientific Investigations Report 2008-5200 


\section{U.S. Department of the Interior \\ KEN SALAZAR, Secretary}

\section{U.S. Geological Survey \\ Suzette M. Kimball, Acting Director}

\section{U.S. Geological Survey, Reston, Virginia: 2009}

For product and ordering information:

World Wide Web: http://www.usgs.gov/pubprod

Telephone: 1-888-ASK-USGS

For more information on the USGS - the Federal source for science about the Earth, its natural and living resources, natural hazards, and the environment:

World Wide Web: http://www.usgs.gov

Telephone: 1-888-ASK-USGS

Any use of trade, product, or firm names is for descriptive purposes only and does not imply endorsement by the U.S. Government.

Although this report is in the public domain, permission must be secured from the individual copyright owners to reproduce any copyrighted materials contained within this report.

Suggested citation:

Manning, A.H., 2009, Ground-water temperature, noble gas, and carbon isotope data from the Española Basin, New Mexico: U.S. Geological Survey Scientific Investigations Report 2008-5200, 69 p. 


\section{Contents}

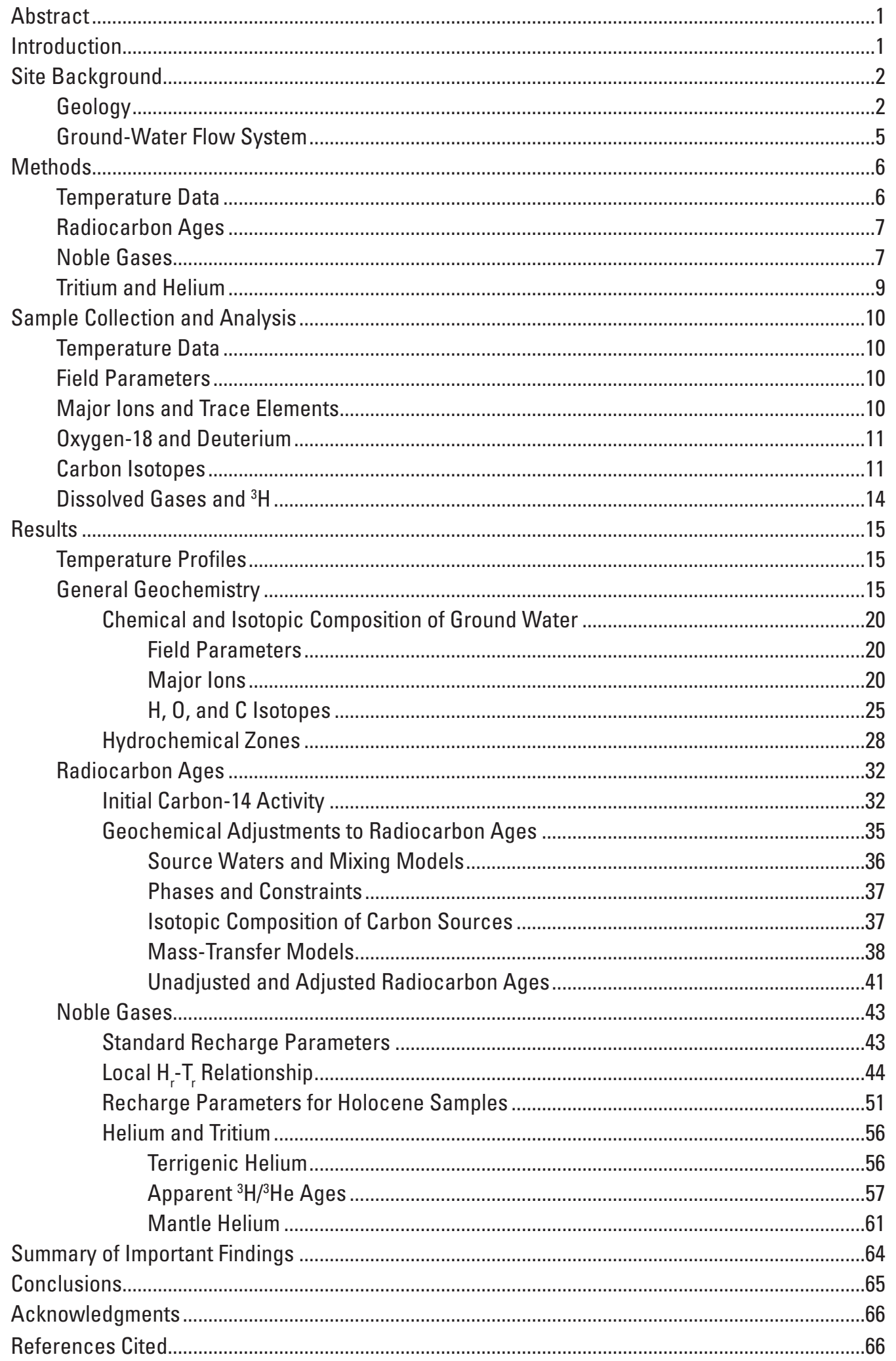




\section{Figures}

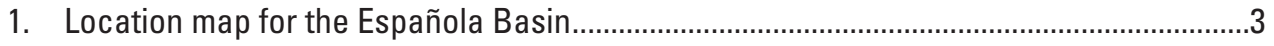

2. Generalized geologic map of the Española Basin area .....................................................

3. Ground-water-table elevation contours in the Española Basin.........................................6

4. Illustration of approach used in this study to constrain recharge temperature $\left(\mathrm{T}_{\mathrm{r}}\right)$ and recharge elevation $\left(\mathrm{H}_{\mathrm{r}}\right)$ for a sample.........................................

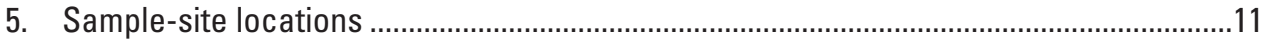

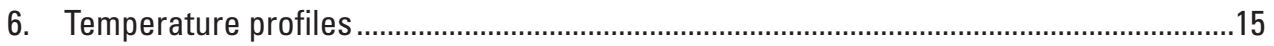

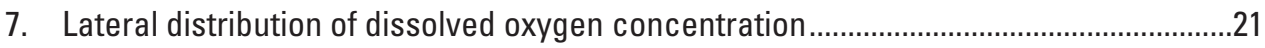

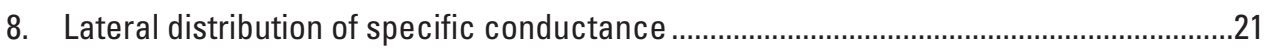

9. Vertical distribution of specific conductance in nested piezometers ............................22

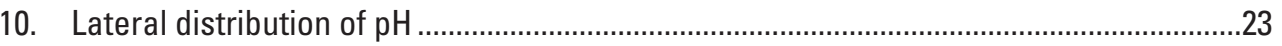

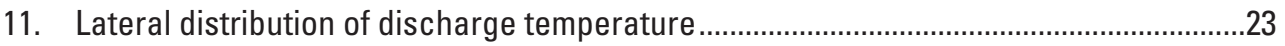

12. $\mathrm{pH}$ versus ${ }^{14} \mathrm{C}$ activity of dissolved inorganic carbon ..................................................24

13. Discharge temperature versus ${ }^{14} \mathrm{C}$ activity of dissolved inorganic carbon..............................

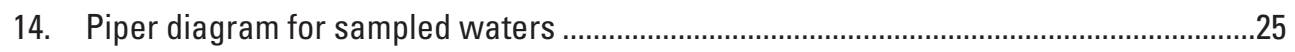

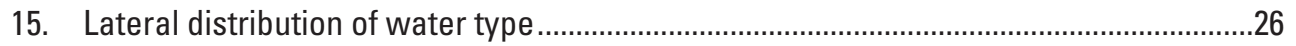

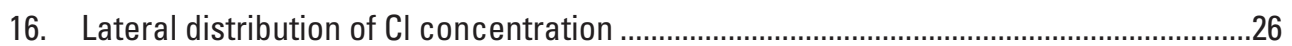

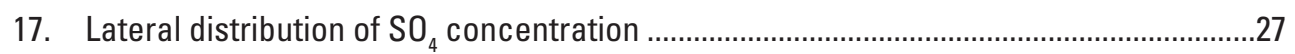

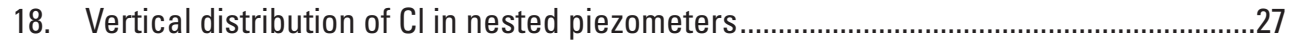

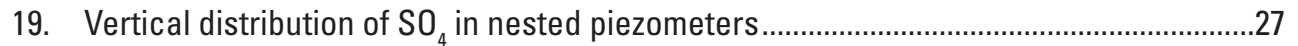

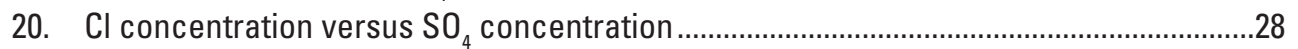

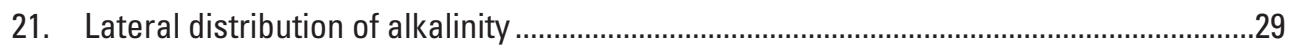

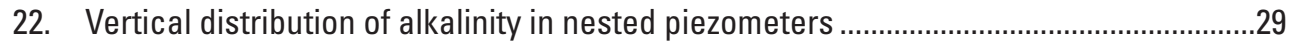

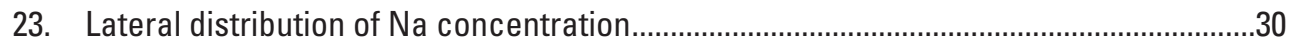

24. Vertical distribution of $\mathrm{Na}$ concentration in nested piezometers...................................30

25. Na concentration versus ${ }^{14} \mathrm{C}$ activity of dissolved inorganic carbon...............................30

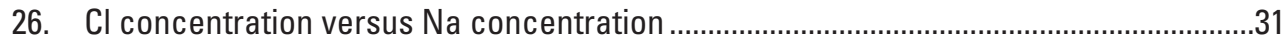

27. $(\mathrm{Na}+\mathrm{K}) / \mathrm{Ca}$ mass ratio versus ${ }^{14} \mathrm{C}$ activity of dissolved inorganic carbon ..............................31

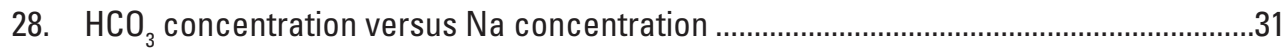

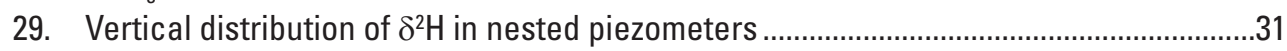

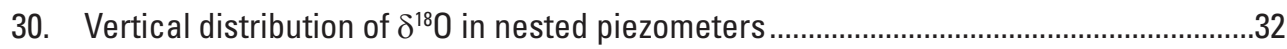

31. $\delta^{2} \mathrm{H}$ versus ${ }^{14} \mathrm{C}$ activity of dissolved inorganic carbon .................................................32

32. $\delta^{18} \mathrm{O}$ versus ${ }^{14} \mathrm{C}$ activity of dissolved inorganic carbon ................................................32

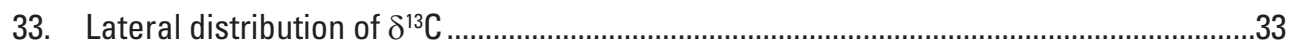

34. Lateral distribution of ${ }^{14} \mathrm{C}$ activity of dissolved inorganic carbon ....................................33

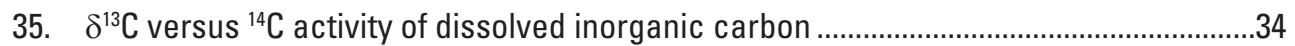

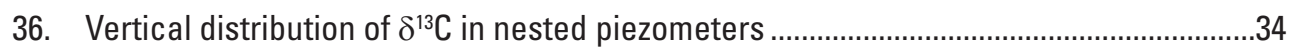

37. Vertical distribution of ${ }^{14} \mathrm{C}$ activity of dissolved inorganic carbon in nested piezometers ...................................................................................................

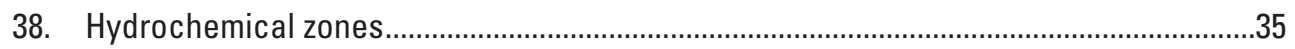

39. ${ }^{3} \mathrm{H}$ concentration versus ${ }^{14} \mathrm{C}$ activity of dissolved inorganic carbon ................................36

40. Lateral distribution of mixing model type.................................................................

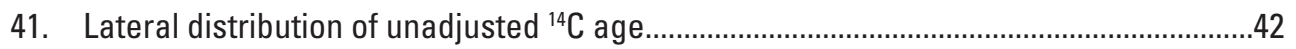

42. Vertical distribution of unadjusted ${ }^{14} \mathrm{C}$ age in nested piezometers.................................43 


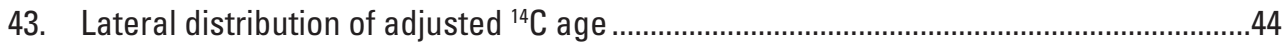

44. Vertical distribution of adjusted ${ }^{14} \mathrm{C}$ age in nested piezometers ...................................45

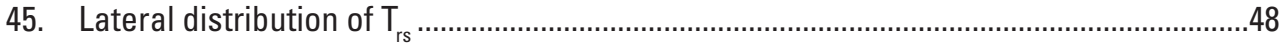

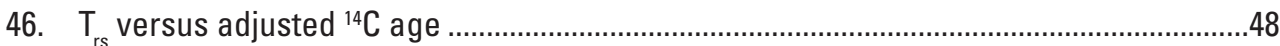

47. Vertical distribution of $\mathrm{T}_{\mathrm{rs}}$ in nested piezometers ......................................................4 48

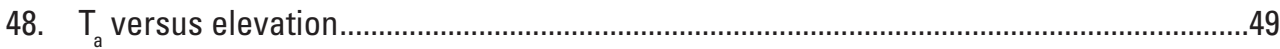

49. Derivation of $\mathrm{H}_{r}-\mathrm{T}_{\mathrm{r}}$ relationships for the east and west sides of the Española Basin.

50. Example of how recharge parameters were derived for Holocene samples using the local $\mathrm{H}_{\mathrm{r}}-\mathrm{T}_{\mathrm{r}}$ relationship ................................................................53

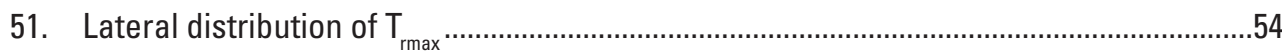

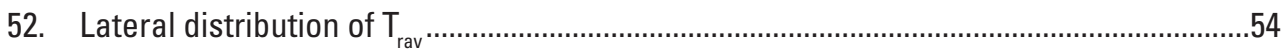

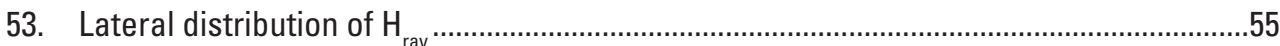

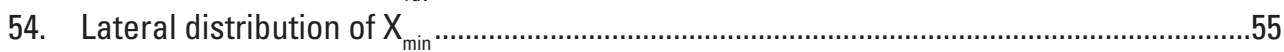

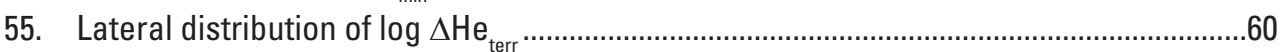

56. Vertical distribution of $\log \Delta \mathrm{He}_{\text {terr }}$ in nested piezometers .............................................60

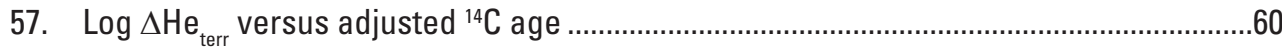

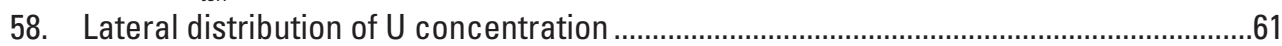

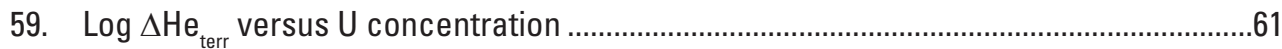

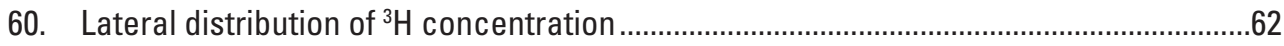

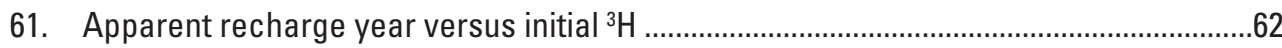

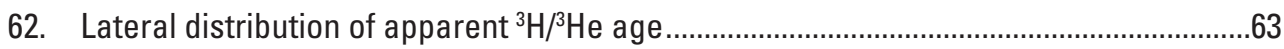

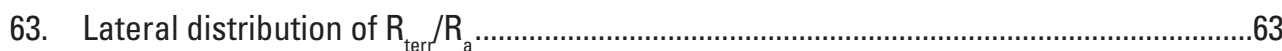

64. Vertical distribution of $R_{\text {terr }} / R_{a}$ in nested piezometers .................................................64

\section{Tables}

1. Definition of recharge and helium terms ………….......................................................

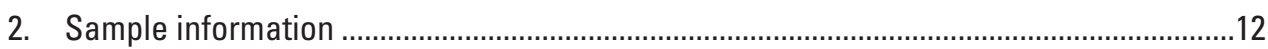

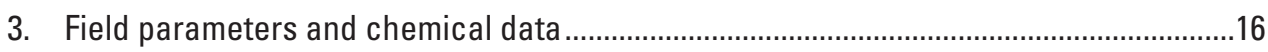

4. Hydrogen and oxygen isotopic data for water, and carbon isotopic

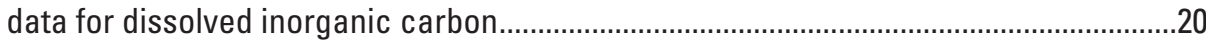

5. Samples apparently impacted by anthropogenic sources..............................................28

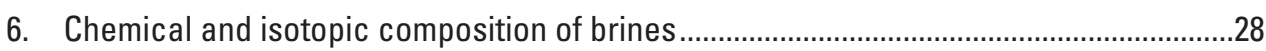

7. Median values of selected chemical and isotopic parameters by

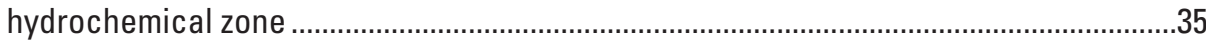

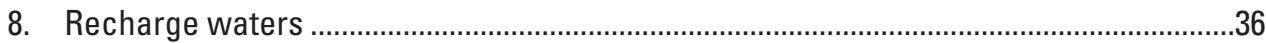

9. Unadjusted radiocarbon ages, preferred geochemical mass-transfer

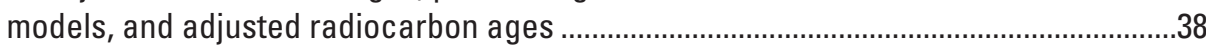

10. Mixing models used in geochemical modeling ................................................................

11. Dissolved gas concentrations and modeled recharge parameters.................................46

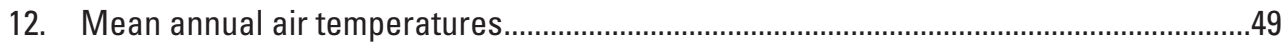

13. Water table temperature and mountain ground-water-discharge temperature measurements .....................................................................................50

14. He and ${ }^{3} \mathrm{H}$ data, modeled $\mathrm{He}$ components, and ${ }^{3} \mathrm{H} /{ }^{3} \mathrm{He}$ ages .........................................58 


\section{Conversion Factors}

SI to Inch/Pound

\begin{tabular}{lcl}
\hline Multiply & By & To obtain \\
\hline centimeter $(\mathrm{cm})$ & Length & \\
meter $(\mathrm{m})$ & 0.3937 & inch (in.) \\
kilometer $(\mathrm{km})$ & 3.281 & foot (ft) \\
& 0.6214 & mile (mi) \\
\hline liter $(\mathrm{L})$ & Volume & \\
cubic centimeter $\left(\mathrm{cm}^{3}\right)$ & 33.82 & ounce, fluid $(\mathrm{fl} . \mathrm{oz})$ \\
\hline & 0.06102 & cubic inch $\left(\mathrm{in}^{3}\right)$ \\
\hline cubic meter per second $\left(\mathrm{m}^{3} / \mathrm{s}\right)$ & Flow rate & \\
cubic meter per year $\left(\mathrm{m}^{3} / \mathrm{yr}\right)$ & 70.07 & acre-foot per day $(\mathrm{acre}-\mathrm{ft} / \mathrm{d})$ \\
\hline & 0.000811 & acre-foot per year $(\mathrm{acre}-\mathrm{ft} / \mathrm{yr})$ \\
\hline gram $(\mathrm{g})$ & Mass & \\
\hline
\end{tabular}

Temperature in degrees Celsius $\left({ }^{\circ} \mathrm{C}\right)$ may be converted to degrees Fahrenheit $\left({ }^{\circ} \mathrm{F}\right)$ as follows:

$$
{ }^{\circ} \mathrm{F}=\left(1.8 \times{ }^{\circ} \mathrm{C}\right)+32
$$

Vertical coordinate information is referenced to the North American Vertical Datum of 1988 (NAVD 88).

Horizontal coordinate information is referenced to the North American Datum of 1927 (NAD 27).

Altitude, as used in this report, refers to distance above the vertical datum.

Specific conductance is given in microsiemens per centimeter at 25 degrees Celsius $(\mu \mathrm{S} / \mathrm{cm}$ at $\left.25^{\circ} \mathrm{C}\right)$.

Concentrations of chemical constituents in water are given either in milligrams per liter (mg/L) or micrograms per liter $(\mu \mathrm{g} / \mathrm{L})$. 


\title{
Ground-Water Temperature, Noble Gas, and Carbon Isotope Data from the Española Basin, New Mexico
}

\author{
By Andrew H. Manning
}

\section{Abstract}

Ground-water samples were collected from 56 locations throughout the Española Basin and analyzed for general chemistry (major ions and trace elements), carbon isotopes $\left(\delta^{13} \mathrm{C}\right.$ and ${ }^{14} \mathrm{C}$ activity) in dissolved inorganic carbon, noble gases ( $\mathrm{He}, \mathrm{Ne}, \mathrm{Ar}, \mathrm{Kr}, \mathrm{Xe}$, and ${ }^{3} \mathrm{He} /{ }^{4} \mathrm{He}$ ratio), and tritium. Temperature profiles were measured at six locations in the southeastern part of the basin. Temperature profiles suggest that ground water generally becomes warmer with distance from the mountains and that most ground-water flow occurs at depths $<250 \mathrm{~m}$ below ground surface. The two dominant water types in the basin are $\mathrm{Ca} / \mathrm{CO}_{3}+\mathrm{HCO}_{3}$ and $\mathrm{Na} / \mathrm{CO}_{3}+\mathrm{HCO}_{3}$, followed by mixed-cation $/ \mathrm{CO}_{3}+\mathrm{HCO}_{3}$. Waters generally evolve from $\mathrm{Ca} / \mathrm{CO}_{3}+\mathrm{HCO}_{3}$ to $\mathrm{Na} / \mathrm{CO}_{3}+\mathrm{HCO}_{3}$ with increasing residence time through $\mathrm{Ca}-\mathrm{Na}$ cation exchange with clay minerals. Basin ground water can be divided into four hydrochemical zones based on chemical and isotopic composition: West, Southeast, Northeast, and Central Deep. Hydrochemical zone boundaries are roughly correlated with contacts between geologic units or lithosome transitions within the Tesuque Formation.

Geochemical mass-transfer modeling was performed using NETPATH and ${ }^{14} \mathrm{C}$ ages were adjusted accordingly. Isotopic input parameters were varied within reasonable limits to assess uncertainty in the adjusted ${ }^{14} \mathrm{C}$ ages. For each sample, a preferred adjusted age was selected from multiple possible adjusted ages based primarily on the fit between measured and modeled $\delta^{13} \mathrm{C}$ values. The range of possible age adjustments for most samples is about 6,000 years or less, indicating that the preferred adjusted age for most samples has a total range of uncertainty of $<6,000$ years. Preferred adjusted ages range from 0 to 35,400 years. First-order trends in the age distribution include older ages generally occurring farther from rivers on the east side of the basin and farther from the mountains, consistent with both mountain-front recharge and recharge on the basin floor in the form of stream-loss and arroyo recharge. Ages also increase with depth in the Southeast zone, the only area where discrete-depth samples could be collected.

Recharge temperatures derived from noble gas concentrations were used in conjunction with an empirically derived local relationship between recharge temperature and elevation to constrain recharge elevation and to estimate fractions of mountain-block recharge (MBR) in sampled waters of Holocene age. Noble gas recharge temperatures indicate that ground water in the Southeast zone contains a significant fraction of MBR, commonly 20-50 percent or more. The same is apparently true for the Northeast zone, though only two data points could be used to evaluate the MBR fraction in this area. Recharge temperatures indicate that the upper $30 \mathrm{~m}$ of the regional aquifer on the Pajarito Plateau typically contain little or no MBR.

Tritium concentrations and apparent ${ }^{3} \mathrm{H} /{ }^{3} \mathrm{He}$ ages indicate that water in the mountain block is dominantly $<50$ years old, and water in the basin-fill is dominantly $>50$ years old, consistent with the ${ }^{14} \mathrm{C}$ ages. Terrigenic $\mathrm{He}\left(\mathrm{He}_{\text {terr }}\right)$ concentrations in ground water are high $\left(\log \Delta \mathrm{He}_{\text {terr }}\right.$ of 2 to 5$)$ throughout much of the basin. High $\mathrm{He}_{\text {terr }}$ concentrations are probably caused by in situ production in the Tesuque Formation from locally high concentrations of U-bearing minerals (Northeast zone only), or by upward diffusive/advective transport of crustal- and mantle-sourced He possibly enhanced by basement piercing faults, or by both. The ${ }^{3} \mathrm{He} /{ }^{4} \mathrm{He}$ ratio of $\mathrm{He}_{\text {terr }}\left(\mathrm{R}_{\text {terr }}\right)$ is commonly high $\left(\mathrm{R}_{\text {terr }} / \mathrm{R}_{\mathrm{a}}\right.$ of $0.3-2.0$, where $\mathrm{R}_{\mathrm{a}}$ is the ${ }^{3} \mathrm{He} /{ }^{4} \mathrm{He}$ ratio in air) suggesting that Española Basin ground water commonly contains mantle-sourced He. The ${ }^{3} \mathrm{He} /{ }^{4} \mathrm{He}$ ratio of $\mathrm{He}_{\text {terr }}$ is generally the highest in the western and southern parts of the basin, closest to the western border fault system and the Quaternary to Miocene volcanics of the Jemez Mountains and Cerros del Rio.

\section{Introduction}

As with most arid and semiarid intermountain basins, ground-water recharge in the Española Basin in northern New Mexico is poorly understood. An uncertainty analysis performed by Keating and others (2003) suggests that total recharge to the basin is relatively well constrained because total discharge is relatively well constrained; most ground water probably leaves the basin as discharge to the Rio Grande and its tributaries, and thus can be directly measured. However, the distribution of recharge is uncertain, and the relative significance of different recharge components is not clear. Ground-water temperature, noble gas, and carbon isotope data were collected in the Española Basin as part of this study to better understand recharge to the basin, particularly to discern the relative contribution of recharge that occurs in the mountains versus recharge that occurs on the basin floor. 
Los Alamos National Laboratory (LANL) has been conducting an intensive effort to characterize the ground-water system beneath the Pajarito Plateau since 1995, primarily to determine the ultimate fate of contaminants released historically at LANL. Support of this study by LANL stems, first, from a need to better understand recharge to the regional aquifer under the Pajarito Plateau where LANL is located. More specifically, the contribution to the regional aquifer system made by infiltration in the Jemez Mountains west of LANL versus infiltration from ephemeral and perennial streams in the canyons traversing the lab facility is a critical issue for determining the susceptibility of the regional aquifer to contaminants released by LANL. Second, as highlighted by recent studies (for example, Vesselinov and Keating, 2002), understanding the basin-scale ground-water flow system is important in characterizing how the local flow system near LANL might be influenced by increased ground-water extraction from the basin-scale flow system, and vice versa. Support for this study by the City of Santa Fe originates from its growing population and need for additional water resources. An improved understanding of the basin-scale ground-water flow system would assist the city in water resource management and planning. An issue of particular interest to the city is the magnitude of infiltration from the Santa Fe River in comparison to infiltration in the mountains east of the city.

Manning and Solomon $(2003,2005)$ demonstrated that temperature, noble gas, and ground-water age data in combination with numerical modeling can place useful constraints on recharge to intermountain basins. Temperature and age data can constrain rates of ground-water flow in different parts of the basin, reducing uncertainties in both total recharge and the recharge distribution. Recharge temperatures computed from noble gas concentrations can constrain recharge elevation, which can be used to distinguish water recharged in the mountains from water recharged on the basin floor. This report presents down-hole temperature profiles, noble gas recharge temperatures, and radiocarbon ages, along with major and trace element data collected to aid in the interpretation of the radiocarbon ages. These data by themselves reveal fundamental aspects of recharge to the Española Basin, which are discussed in this report. However, the ultimate objective for collecting these data was to provide additional calibration targets for LANL's existing numerical ground-water flow model of the basin. Such a recalibrated model could have considerably lower recharge parameter uncertainties and could provide important new insights into recharge to the basin.

\section{Site Background}

The Española Basin in northern New Mexico is one of a series of ground-water basins within the Rio Grande rift, a major continental rift zone extending from Colorado to Mexico (fig. 1). The Española Basin is an intermountain basin, bound on the west by the Jemez Mountains, rising to 3,200 meters above sea level (masl), and on the east by the Sangre de Cristo Mountains, rising to 3,800 masl. The basin boundary shown in figure 1 corresponds to the boundary of the basin groundwater flow model constructed by Keating and others (2003). It includes the mountain blocks on either side of the basin, extending to the topographic divide at each range crest. This hydrologic definition differs from a more geologic definition used by many previous authors (for example, Wilkins, 1986) in which the basin boundary corresponds to the lateral extent of the basin-fill deposits. Basin-floor elevations are 1,700-2,200 masl. The Rio Grande flows southwestward along the axis of the basin. The climate is semiarid for most elevations, the basin floor receiving $20-40 \mathrm{~cm} / \mathrm{yr}$ of precipitation and the mountains receiving $50-100 \mathrm{~cm} / \mathrm{yr}$.

\section{Geology}

The following overview of the geology of the Española Basin is synthesized from more detailed descriptions of the basin geology presented by Spiegel and Baldwin (1963), Galusha and Blick (1971), Manley (1978, 1979), Wilkins (1986), Purtymun (1995), and the New Mexico Bureau of Geology and Mineral Resources (2003). Dominant rock types and general geologic features in the area are shown in figure 2. Crustal extension that formed the Rio Grande rift began in the late Oligocene and continues into the present. The Sangre de Cristo Mountains on the eastern side of the basin are composed mostly of Proterozoic metasedimentary rocks (schist and quartzite with subordinate amphibolite) and granitic plutonic rocks (variably foliated granites and granitic gneisses). A section of the Sangre de Cristo Mountains in the northeasternmost portion of the study area is composed of Pennsylvanian and Permian sedimentary rocks (primarily limestones). The Jemez Mountains on the western side of the basin are composed of intermediate to silicic volcanic rocks that are Miocene to Quaternary age. Basin-fill sediments and sedimentary rocks between the two mountain ranges are mostly Miocene to Pliocene age and belong to the Santa Fe Group. The Santa Fe Group is an extensive unit that includes basin-fill deposits within multiple basins along the Rio Grande rift. Wilkins (1986, fig. 1, p. 4) presents a chart correlating equivalent units of the Santa Fe Group within these different basins. In the Española Basin, the thickness of the Santa Fe Group ranges from $0 \mathrm{~m}$ at the contact with the Sangre de Cristo Mountains to as much as 2,000 to 3,000 m in the central and western parts of the basin. In the western and southwestern portions of the basin, including the Pajarito Plateau and Cerro del Rio, the Santa Fe Group is overlain by and interbedded with Miocene to Quaternary volcanic and volcaniclastic rocks. Those on the Pajarito Plateau largely originated from the Jemez volcanic field to the west. The western extent of the basin-fill is defined by the Pajarito fault zone. This zone of dominantly down-to-the-east faults is covered to a large extent by volcanics of Jemez Mountains, but exposures north and south of the Jemez Mountains show 100- to 


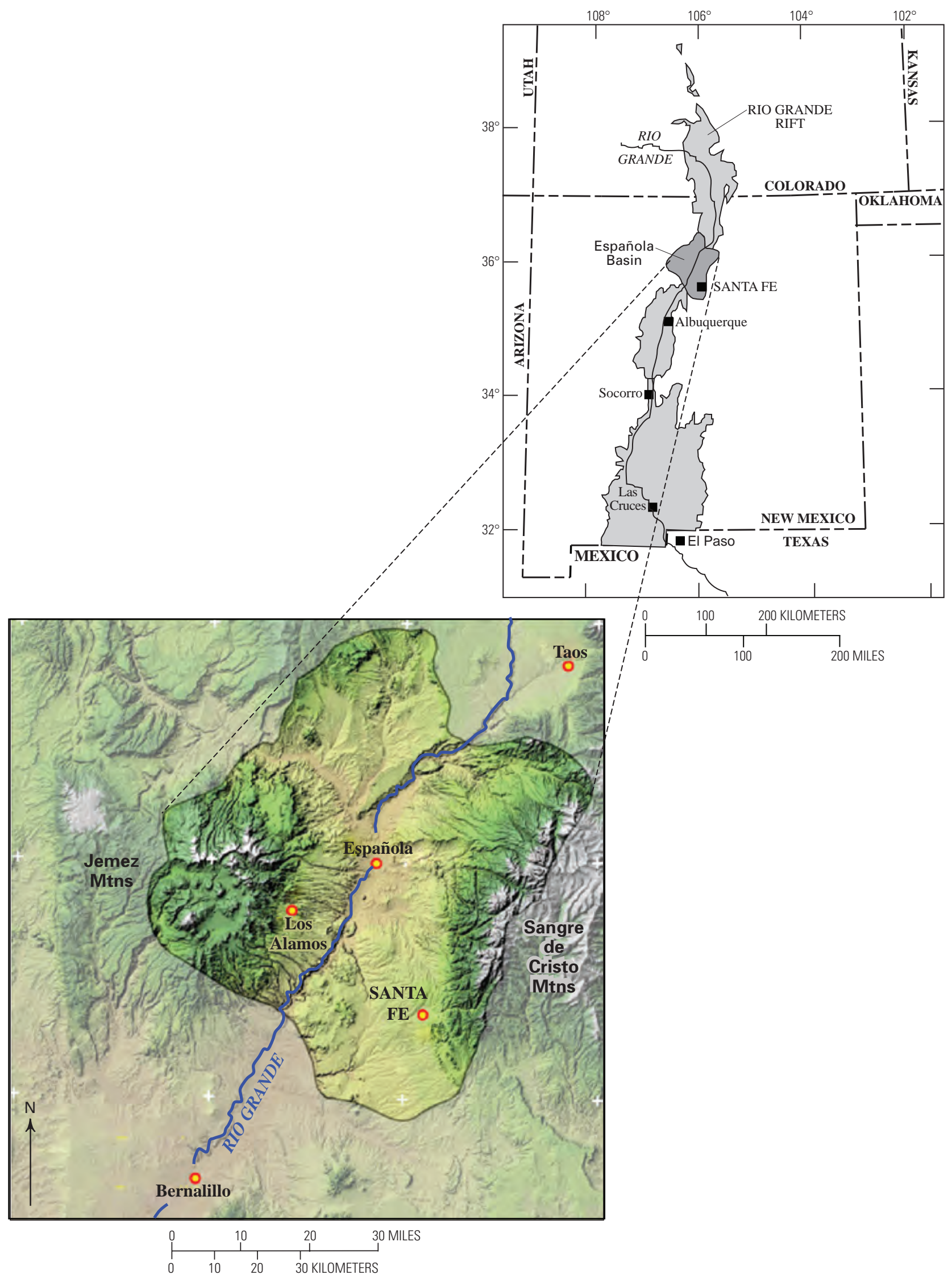

Figure 1. Location map for the Española Basin. Land surface image from satellite data in Sawyer (2004). Illustration courtesy of V.J.S. Grauch. 


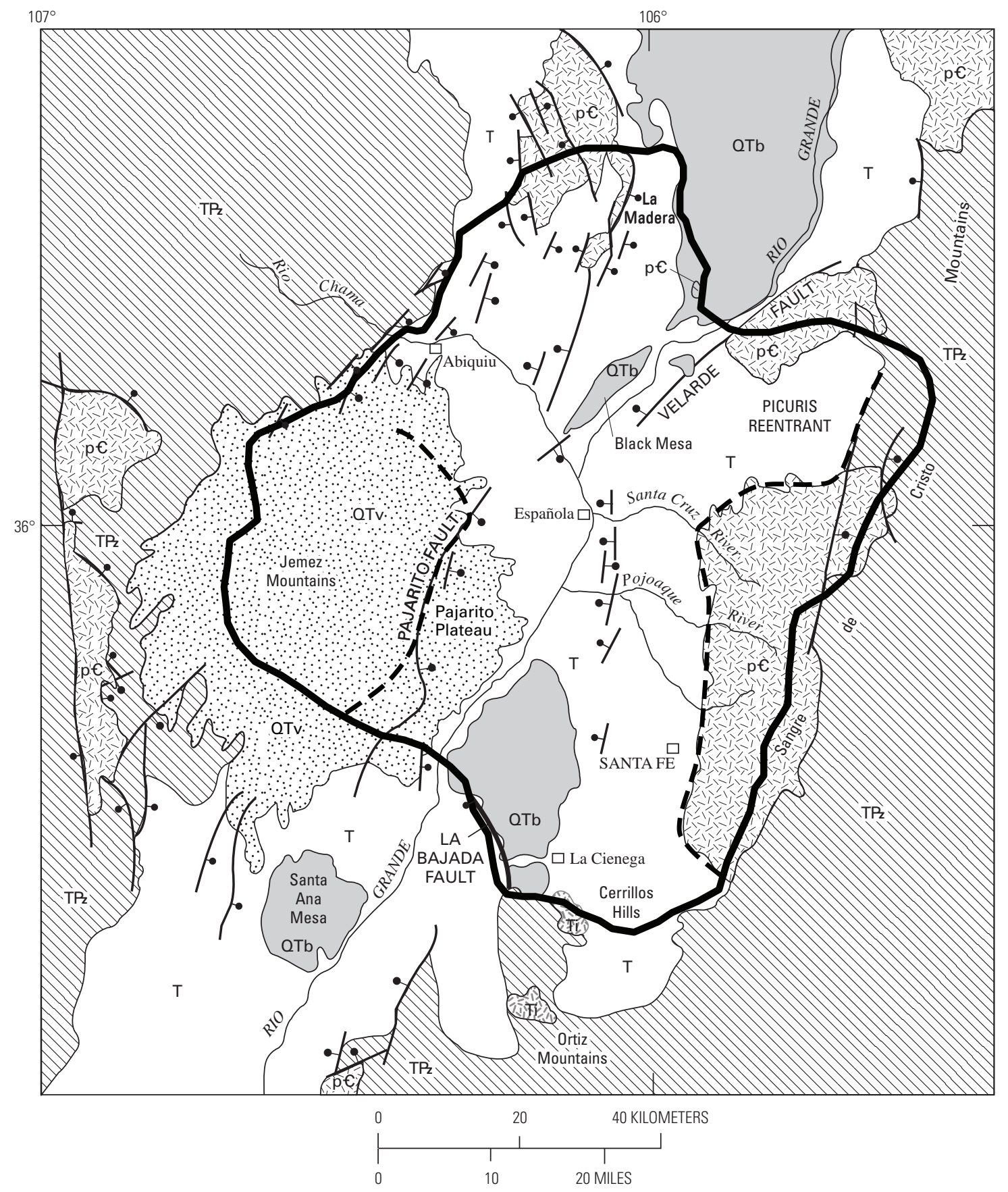

EXPLANATION

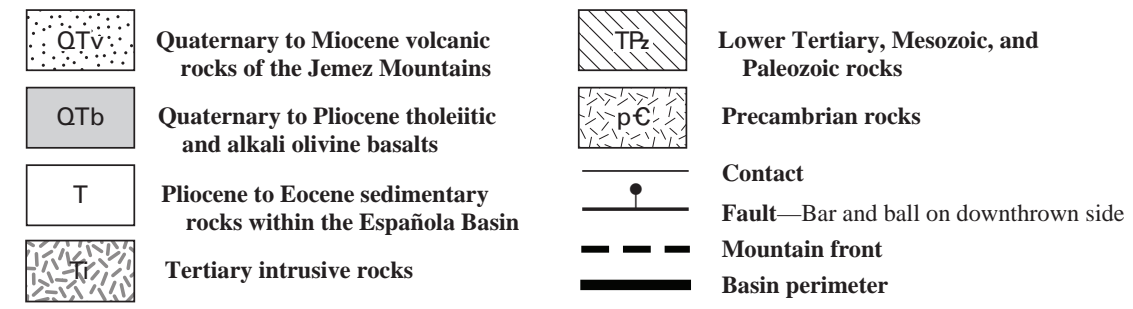

Figure 2. Generalized geologic map of the Española Basin area from Manley (1979). 
1,000-m-scale offsets that place upper Tertiary Santa Fe Group rocks against Mesozoic rocks. The eastern side of the basin lacks a clear range-bounding fault; fault contacts between the basin-fill and metamorphic basement are poorly defined, and in many locations Santa Fe Group rocks appear to be in depositional contact with the basement.

The Miocene Tesuque Formation is the dominant unit of the Santa Fe Group in the Española Basin. The Tesuque Formation is the principal aquifer throughout most of the basin, and nearly all wells sampled in this study located off the Pajarito Plateau are completed in the Tesuque Formation. The formation consists of variably consolidated sandstone, siltstone and claystone, and pebble conglomerate. Source rocks are mostly the Proterozoic metamorphic and granitic rocks of the Sangre de Cristo Mountains, and to a minor degree, the previously overlying Paleozoic sedimentary rocks that now crop out to the north and east of the metamorphic core of the uplift. Sampled wells located on the Pajarito Plateau are screened within Miocene and Pliocene volcaniclastic and volcanic rocks that overlie the Tesuque Formation in this part of the basin.

The dashed line on figure 2 corresponds to the boundary between the mountain block and basin floor, referred to herein as the "mountain front." The mountain front is well defined on the eastern side of the basin, corresponding to the contact between the Proterozoic rocks (or Paleozoic rocks in part of the Picuris reentrant) and the Tertiary basin-fill deposits. The east-side mountain-front elevation is typically about 2,200 $\mathrm{m}$. On the western side of the basin, the mountain front is well defined in the vicinity of the Pajarito Plateau, corresponding to the Pajarito fault zone. The Pajarito Plateau is therefore considered part of the basin floor. To the north and south of the Pajarito Plateau, the mountain front is not well defined geologically, but instead corresponds to a relatively distinct topographic transition between the mountains and flanking plateau. The west-side mountain-front elevation is typically about $2,400 \mathrm{~m}$, which is higher than on the east side.

\section{Ground-Water Flow System}

Detailed descriptions of the hydrologic system in the Española Basin can be found in Speigel and Baldwin (1963), McAda and Wasiolek (1988), and Purtymun and others (1995). Figure 3 shows ground-water-level contours for the Española Basin. Ground water generally flows from the mountains toward the Rio Grande, where most of the ground water discharges. The unsaturated zone is 0 to $60 \mathrm{~m}$ thick throughout most of the basin, but it is much thicker on the Pajarito Plateau (up to $350 \mathrm{~m}$ ) where perched aquifers exist. Total recharge to the Española Basin is about 4,100 kg/s (103,000 acre-ft/yr) according to the only existing ground-water flow model of the entire basin, which was constructed by Keating and others (2003). For the portion of the basin south of the city of Española, where most ground-water extraction occurs, total recharge is about $2,100 \mathrm{~kg} / \mathrm{s}(53,000 \mathrm{acre}-\mathrm{ft} / \mathrm{yr})$ according to ground-water flow models that include this area (McAda and Wasiolek, 1988; Keating and others, 2003). These modeling studies suggest that 80-90 percent of recharge is in the form of mountain-front recharge (MFR); the remaining 10-20 percent recharge is subsurface inflow from adjacent basin areas and possibly distributed infiltration on the basin floor and loss from the Rio Grande. These studies also suggest that most MFR (70-80 percent) occurs on the east side of the basin. Chloride measurements by Anderholm (1994) from the unsaturated zone suggest that nearly all infiltration on the basin floor occurs in stream or arroyo channels.

Complete discussions of MFR to intermountain basins, its components, methods used to estimate it, and uncertainties in these estimates are provided by Wilson and Guan (2004) and Manning and Solomon (2004). Mountain-front recharge has two components: "mountain-block recharge" (MBR) and "stream loss." Mountain-block recharge is water that infiltrates in the mountain block, flows to lower elevations in the mountain-block ground-water system, then enters the basin-fill aquifer in the subsurface. Stream loss is water that exits the mountain block as surface water, then subsequently infiltrates near the mountain front through the beds of perennial and ephemeral streams as they traverse the basin-fill. Stream loss might also occur farther out in the basin, away from the mountain front. Stream loss and distributed recharge on the basin floor will henceforth be referred to as "basin-fill recharge" (BFR).

The distribution between MBR and stream loss in the Española Basin is uncertain. According to existing basin-flow models (McAda and Wasiolek, 1988; Keating and others, 2003), MBR typically composes 30-100 percent of MFR, depending on location. These large MBR estimates are supported by a mountain-water budget analysis performed for drainages in the Sangre de Cristo Mountains by Wasiolek (1995), which yielded MBR estimates for the southeastern part of the basin similar to or greater than those of McAda and Wasiolek (1988) and Keating and others (2003). In contrast, a chloride mass-balance study performed in the southeastern part of the basin by Anderhohm (1994) yielded MFR estimates about 70 percent less than those made by McAda and Wasiolek (1988) and Keating and others (2003). Furthermore, whereas McAda and Wasiolek (1988) and Wasiolek (1995) estimated that MBR is 40-50 percent of MFR near the Santa Fe River, surface-water chloride concentrations in the Santa Fe River reported by Anderholm (1994) suggest that essentially no MBR occurs in this area. Finally, the estimated thickness of aquifers in crystalline rock in mountainous terrain is typically 100-200 m (see Manning and Caine, 2007). This shallow circulation depth means that ground-water flow in the crystalline rocks composing the Sangre de Cristo Mountain block should generally follow local topographic gradients, as opposed to the regional topographic gradient (toward the basin floor), and discharge into mountain streams. The result would be relatively little direct ground-water flow to the basinfill, aside from underflow where mountain streams exit the mountain block. 


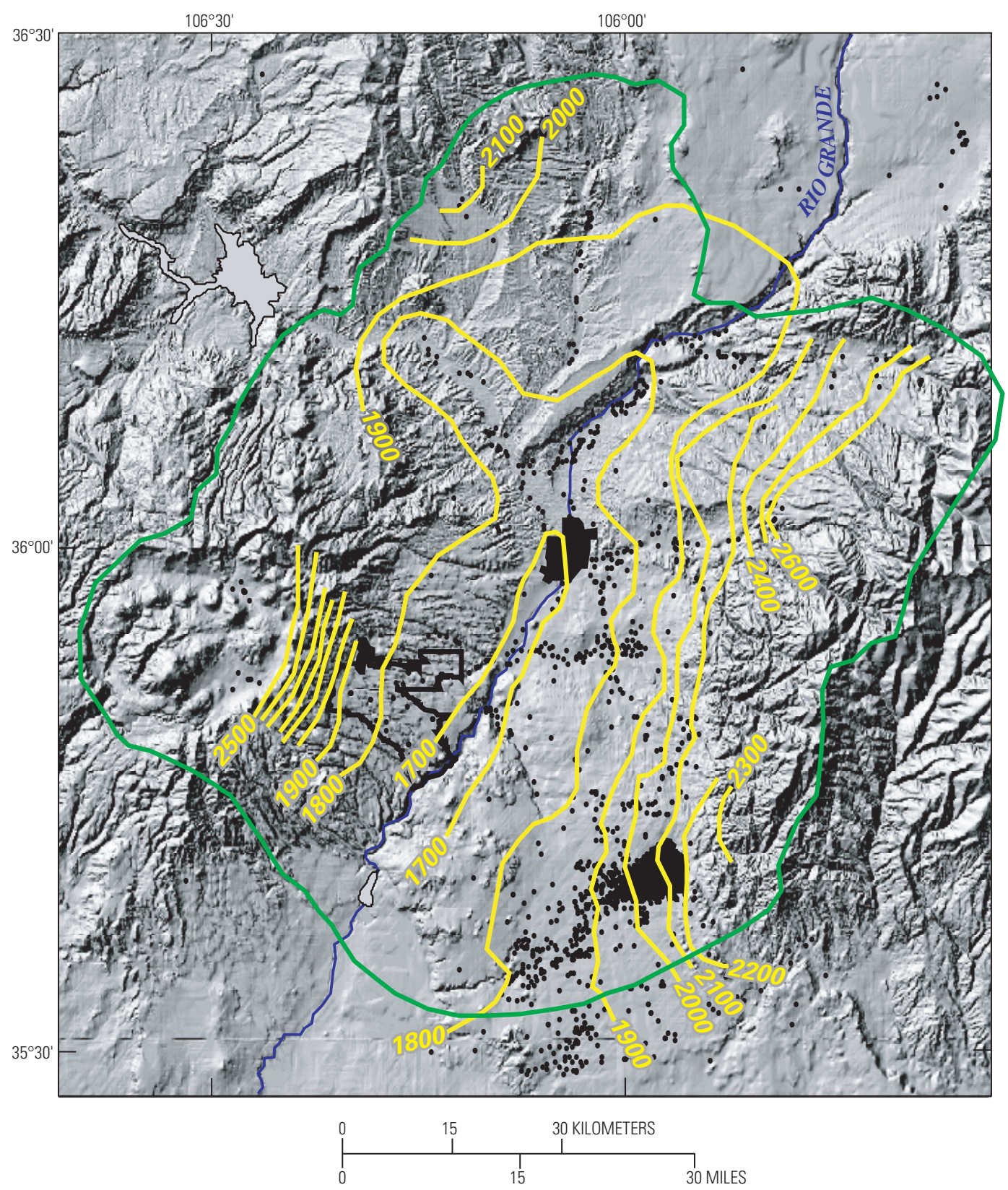

Figure 3. Ground-water-table elevation contours in the Española Basin. Small black dots indicate measurement locations. Green shows basin perimeter. From Keating and others (2003). Contour interval is $100 \mathrm{~m}$.

\section{Methods}

\section{Temperature Data}

Ground-water temperatures are sensitive to ground-water flow rates. Anderson (2005) provides a thorough review of existing methods of using ground-water temperature data in conjunction with numerical coupled heat and fluid transport modeling to constrain ground-water flow rates. In general, ground-water warms along flow paths at a rate that is dependent upon the rate of flow, meaning that the temperature distribution in an aquifer can be used to constrain the recharge rate.
The shape of temperature profiles reveals information about the vertical component of ground-water flow (Bredehoeft and Papadopulos, 1965; Mansure and Reiter, 1979). Linear profiles with a gradient similar to the local geothermal gradient typically indicate vertical ground-water flow rates less than approximately $1 \mathrm{~cm} / \mathrm{yr}$ (Darcy velocity), sufficiently low to result in little or no advective heat transport. Curved profiles result from advective heat transport and typically indicate vertical ground-water flow rates greater than approximately $1 \mathrm{~cm} / \mathrm{yr}$. Concave upward profiles (thermal gradient increasing with depth) indicate downflow and are characteristic of recharge areas. Concave downward profiles (thermal gradient 
decreasing with depth) indicate upflow and are characteristic of discharge areas. Temperature profiles have been used at other locations within the Rio Grande rift to quantify vertical ground-water flow velocities and identify important aspects of the flow system (for example, Reiter, 1999). Temperature profiles were collected in this study primarily to provide sufficient temperature data (in combination with existing profiles) to allow for calibration of LANL's basin ground-water flow with temperature data as well as hydraulic head data, and in so doing improve constraints on recharge parameters.

\section{Radiocarbon Ages}

A comprehensive review of the radiocarbon ground-water dating method is provided by Kalin (2000). The method is based on the radioactive decay of the isotope ${ }^{14} \mathrm{C}$ (half-life of 5,730 $\mathrm{yr}$ ) in the carbon dissolved in ground water-dissolved inorganic carbon (DIC) in this study. ${ }^{14} \mathrm{C}$ is produced in the upper atmosphere by cosmic rays interacting with atmospheric ${ }^{14} \mathrm{~N}$ and mixes into the lower atmosphere in the form of ${ }^{14} \mathrm{CO}_{2}$. By convention, the modern pre-1950 (pre-nuclear testing) activity of atmospheric ${ }^{14} \mathrm{C}$ is 100 parts modern carbon (pmC). ${ }^{14} \mathrm{C}$ enters the ground-water system during recharge as soil $\mathrm{CO}_{2}$ produced by plant root respiration and microbial degradation of organic material dissolves in infiltrating ground water. After entering the saturated zone, interaction with soil $\mathrm{CO}_{2}$ ceases and ${ }^{14} \mathrm{C}$ in the DIC decays with time. In addition to radioactive decay, multiple other factors affect the activity of ${ }^{14} \mathrm{C}$ in ground water, including the following:

1. Chemical reactions in the unsaturated zone involving DIC, which influence the initial ${ }^{14} \mathrm{C}$ activity $\left(\mathrm{A}_{0}\right)$ at the point where the water enters the saturated zone;

2. Chemical reactions in the saturated zone involving DIC, which can introduce $\mathrm{C}$ from mineral phases that have been isolated from the atmosphere considerably longer than the ground water, thus lowering the ${ }^{14} \mathrm{C}$ activity of the DIC;

3. Mixing with ground water of a different age, most notably older ground water from considerable depth containing DIC with a much lower ${ }^{14} \mathrm{C}$ activity; and

4. Historical variations in the atmospheric ${ }^{14} \mathrm{C}$ activity.

All of these factors are considered in this study in modeling ${ }^{14} \mathrm{C}$ ages from measured ${ }^{14} \mathrm{C}$ activities.

As with ground-water temperature, the rate at which ground-water age increases along a flow path is dependent upon the flow rate. Therefore, the ground-water age distribution can be used to constrain flow rates, and thus recharge rates, in different parts of a flow system when coupled with a numerical ground-water flow model and a knowledge of the porosity distribution. Ground-water ages are also useful for identifying recharge areas, which have the youngest ages. The radiocarbon age dating method was applied in this study because existing recharge estimates suggest that the age of most ground water in the basin should be on the order of thousands to tens of thousands of years. Tritium data were also collected from some sample locations to determine the presence or absence of ground water recharged within the past $50 \mathrm{yr}$ (see the following description of method).

\section{Noble Gases}

A comprehensive review of how atmospheric noble gases are used as ground-water tracers is provided by Stute and Schlosser (2000). Atmospheric concentrations of the noble gases $\mathrm{He}, \mathrm{Ne}, \mathrm{Ar}, \mathrm{Kr}$, and $\mathrm{Xe}$ are constant throughout the world. Noble gases are dissolved in water that is in contact with the atmosphere (precipitation and surface water) at concentrations dependent upon the temperature and atmospheric pressure at which gas exchange occurs. As precipitation or stream water infiltrates through the unsaturated zone, gas exchange continues between the infiltrating water and unsaturated-zone air. Gas exchange with the atmosphere ceases when water enters the saturated zone. Concentrations of dissolved noble gases in ground water are therefore dependent upon the temperature and pressure at the water table at the location of recharge, or the "recharge temperature" $\left(\mathrm{T}_{\mathrm{r}}\right)$ and "recharge pressure" $\left(\mathrm{P}_{\mathrm{r}}\right)$, respectively (see table 1 for definition of all recharge parameters). $\mathrm{P}_{\mathrm{r}}$ is very nearly the same as the atmospheric pressure at the land surface above. $\mathrm{P}_{\mathrm{r}}$ is thus a direct function of the land surface elevation at the recharge location, or the "recharge elevation" $\left(\mathrm{H}_{\mathrm{r}}\right)$. $\mathrm{T}_{\mathrm{r}}$ is close to the mean annual air temperature $\left(\mathrm{T}_{\mathrm{a}}\right)$ at the land surface above. $\mathrm{T}_{\mathrm{r}}$ is commonly $1^{\circ}-3^{\circ} \mathrm{C}$ warmer than $\mathrm{T}_{\mathrm{a}}$ for typical water table depths of $<50 \mathrm{~m}$ (Domenico and Schwartz, 1990). Deeper water tables are significantly influenced by the geothermal gradient, resulting in water table temperatures several degrees above $\mathrm{T}_{\mathrm{a}}$. Deeper water tables also require that $\mathrm{H}_{\mathrm{r}}$ and the water table elevation at the recharge location $\left(\mathrm{H}_{\mathrm{rw}}\right)$ be considered separately in the interpretation of noble gas data.

In addition to $\mathrm{H}_{\mathrm{r}}$ and $\mathrm{T}_{\mathrm{r}}$, a third factor controlling groundwater noble gas concentrations is "excess air." Excess air is the component of the dissolved gas phase that exceeds the air-solubility component (described above), and has nearly the same composition as air (Heaton and Vogel, 1981). Excess air is ubiquitous in ground water and is believed to be the result of complete or partial dissolution of air bubbles trapped near the water table when the water table rises. The hydrostatic pressure on the trapped bubbles exceeds the atmospheric pressure at the water table above, allowing additional air dissolution from the bubbles. Multiple models have been proposed for excess air formation (see Kipfer and others, 2002). The most comprehensive model is the closed-system equilibration (CE) model proposed by Aeschbach-Hertig and others (2000) in which excess air concentrations are controlled by two parameters, $A_{e}$ and $F . A_{e}$ is the amount of air trapped when the water table rises, in units of cubic centimeters at standard 
Table 1. Definition of recharge and helium terms.

[NA, not applicable]

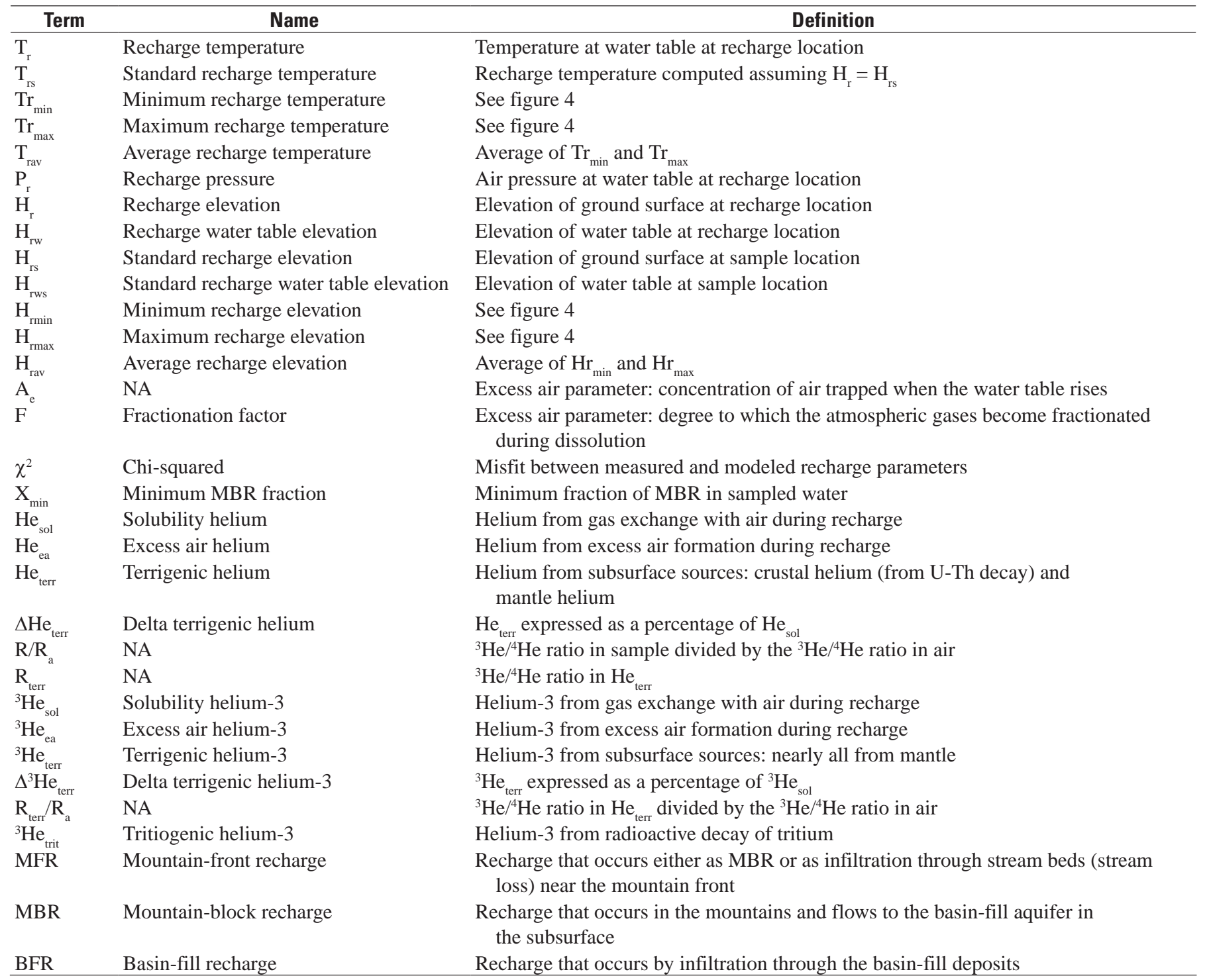

temperature and pressure per gram of water $\left(\mathrm{cm}^{3} \mathrm{STP} / \mathrm{g}\right)$. F is a unitless number between 0 and 1 that describes the degree to which the atmospheric gases become fractionated during dissolution. $\mathrm{F}$ is directly dependent upon the degree to which the trapped bubbles dissolve (more dissolution leads to less fractionation). The $\mathrm{CE}$ model of excess air formation is assumed in this study.

Because noble gases are chemically inert, their concentrations seldom change as ground water flows through the saturated zone (except for He, as in the following discussion). The measurement of dissolved noble gases in a ground-water sample therefore can provide reliable information on the recharge parameters controlling their concentrations: $\mathrm{T}_{\mathrm{r}}$ (thus $\mathrm{T}_{\mathrm{a}}$ ), $\mathrm{H}_{\mathrm{r}}, \mathrm{A}_{\mathrm{e}}$, and $\mathrm{F}$. Recharge parameters are derived from measured noble gas concentrations (typically $\mathrm{Ne}, \mathrm{Ar}, \mathrm{Kr}$, and $\mathrm{Xe}$ ) by simultaneously solving the system of equations relating the concentration of each gas to the recharge parameters. In this study, a computer code employing a chi-squared minimization method like that described by Aeschbach-Hertig and others (1999) and Manning and Solomon (2003) was used to derive recharge parameters from the measured gas concentrations. Chi-squared $\left(\chi^{2}\right)$ is a measure of the misfit between measured and modeled recharge parameters, and its magnitude indicates the probability that the model indeed describes the data.

$\mathrm{T}_{\mathrm{r}}$ and $\mathrm{H}_{\mathrm{r}}$ are highly correlated parameters, meaning that different combinations of $\mathrm{T}_{\mathrm{r}}$ and $\mathrm{H}_{\mathrm{r}}$ can produce nearly the same set of dissolved noble gas concentrations. Solving for all four recharge parameters simultaneously therefore is not possible given current levels of analytical precision; uncertainties in the derived parameters are unacceptably large. This means 
that $\mathrm{H}_{\mathrm{r}}$, of primary interest in this study, cannot be determined directly. Most ground-water studies that have utilized noble gas data are paleoclimate studies in which $\mathrm{T}_{\mathrm{r}}$ is mostly of interest (for example, Stute and others, 1992). These have been performed in aquifers for which the recharge elevation is well constrained, so $\mathrm{H}_{\mathrm{r}}$ is known. This reduces the number of unknown recharge parameters to three, leading to acceptable uncertainties in derived values of $\mathrm{T}_{\mathrm{r}}, \mathrm{A}_{\mathrm{e}}$, and $\mathrm{F}$.

Despite the problem of $\mathrm{H}_{\mathrm{r}}$ and $\mathrm{T}_{\mathrm{r}}$ being highly correlated, noble gases can provide useful constraints on $\mathrm{H}_{\mathrm{r}}$ if the relationship between $\mathrm{H}_{\mathrm{r}}$ and $\mathrm{T}_{\mathrm{r}}$ in the recharge area is known (Manning and Solomon, 2003). This approach takes advantage of the fact that $\mathrm{T}_{\mathrm{r}}$ generally decreases with some regularity as $\mathrm{H}_{\mathrm{r}}$ increases because $\mathrm{T}_{\mathrm{a}}$ generally decreases systematically with increasing elevation. Some studies (for example, Zuber and others, 1995) have assumed a simple relationship between $\mathrm{H}_{\mathrm{r}}$ and $\mathrm{T}_{\mathrm{r}}$ based on a local relationship between $\mathrm{T}_{\mathrm{a}}$ and $\mathrm{H}_{\mathrm{r}}$ (based on meteorological data) and an assumed simple relationship between $\mathrm{T}_{\mathrm{r}}$ and $\mathrm{T}_{\mathrm{a}}$ (for example, $\mathrm{T}_{\mathrm{r}}=\mathrm{T}_{\mathrm{a}}-1^{\circ} \mathrm{C}$ ). However, Manning and Solomon (2003) demonstrated that such simple assumed $\mathrm{H}_{\mathrm{r}}-\mathrm{T}_{\mathrm{r}}$ relationships are dubious for fractured-rock aquifers in mountainous terrain. Water table temperatures may vary considerably at a given elevation in the mountains due to seasonal influxes of snow-melt water and large local-scale climatic variations. A more reliable approach is to derive a local $\mathrm{H}_{\mathrm{r}}-\mathrm{T}_{\mathrm{r}}$ relationship empirically.

Noble gas concentrations are used to constrain $\mathrm{H}_{\mathrm{r}}$ in this study by applying the same methodology as Manning and Solomon (2003) (fig. 4). A "solution zone" is first defined in $\mathrm{H}_{\mathrm{r}}-\mathrm{T}_{\mathrm{r}}$ space (plot of $\mathrm{H}_{\mathrm{r}}$ vs. $\mathrm{T}_{\mathrm{r}}$ ) that includes the observed range

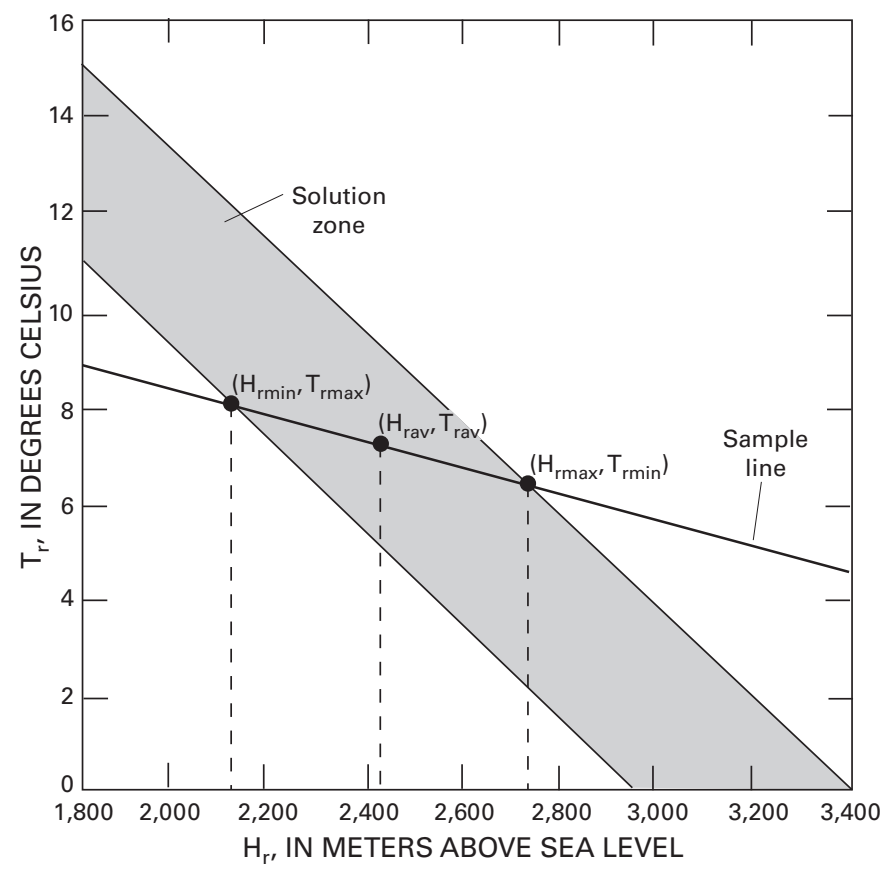

Figure 4. Illustration of approach used in this study to constrain recharge temperature $\left(\mathrm{T}_{\mathrm{r}}\right)$ and recharge elevation $\left(\mathrm{H}_{\mathrm{r}}\right)$ for a sample. See table 1 for explanation of abbreviations. of $T_{r}$ values at each elevation. Shallow ground temperature measurements, ground-water temperature measurements, and/ or noble-gas-derived $\mathrm{T}_{\mathrm{r}}$ determinations at various elevations within the recharge zone can all be employed in defining the solution zone. A series of $\mathrm{H}_{\mathrm{r}}-\mathrm{T}_{\mathrm{r}}$ pairs are then derived for each sample from the measured noble gas concentrations. These $\mathrm{H}_{\mathrm{r}}-\mathrm{T}_{\mathrm{r}}$ pairs define a "sample line" when connected in $\mathrm{H}_{\mathrm{r}}-\mathrm{T}_{\mathrm{r}}$ space. The point where the sample line intersects the solution zone on the left side defines the minimum $\mathrm{H}_{\mathrm{r}}\left(\mathrm{H}_{\mathrm{rmin}}\right)$ and maximum $\mathrm{T}_{\mathrm{r}}\left(\mathrm{T}_{\mathrm{rmax}}\right)$ for the sample, and the point where the sample line intersects the solution zone on the right side defines the maximum $\mathrm{H}_{\mathrm{r}}\left(\mathrm{H}_{\mathrm{rmax}}\right)$ and minimum $\mathrm{T}_{\mathrm{r}}\left(\mathrm{T}_{\mathrm{rmin}}\right)$ for the sample. An average $\mathrm{H}_{\mathrm{r}}\left(\mathrm{H}_{\mathrm{rav}}\right)$ and $\mathrm{T}_{\mathrm{r}}\left(\mathrm{T}_{\mathrm{rav}}\right)$ for the sample can also be derived by averaging the minimum and maximum values. $\mathrm{H}_{\text {rav }}$ and $\mathrm{T}_{\text {rav }}$ constitute a best estimate of the true $\mathrm{H}_{\mathrm{r}}$ and $\mathrm{T}_{\mathrm{r}}$ for the sample. $\mathrm{H}_{\text {rav }}$ and $\mathrm{T}_{\text {rav }}$ are equivalent to $\mathrm{H}_{\mathrm{rprob}}$ and $\mathrm{T}_{\mathrm{rprob}}$ as defined by Manning and Solomon (2003). The terminology is changed here because these values arguably are no more probable than the minimum or maximum values. However, as individual values, they do better represent the range of possible $H_{r}$ and $T_{r}$ values for the sample than the minimum or the maximum value. $\mathrm{H}_{\mathrm{rmin}}$ and $\mathrm{H}_{\mathrm{rmax}}$ can serve as useful constraints on recharge elevation, and thus the relative contribution of MBR to a basin-fill aquifer (Manning and Solomon, 2003).

In the present study, a "standard recharge temperature" $\left(\mathrm{T}_{\mathrm{rs}}\right)$ is computed for each sample assuming $\mathrm{H}_{\mathrm{r}}$ is equal to the land surface elevation at the sample location $\left(\mathrm{H}_{\mathrm{rs}}\right) . \mathrm{T}_{\mathrm{rs}}$ provides a basis for comparing the recharge temperatures of all samples collected in the basin. $\mathrm{T}_{\text {rav }}, \mathrm{T}_{\text {rmin }}$, or $\mathrm{T}_{\text {rmax }}$ cannot be used because they can only be computed for samples with ages $<11,550$ yr. Older samples recharged during the Pleistocene Epoch when the climate regime in the Española Basin, and thus the local $\mathrm{H}_{\mathrm{r}}-\mathrm{T}_{\mathrm{r}}$ relationship, were different from today's (Phillips and others, 1986; Stute and others, 1992).

\section{Tritium and Helium}

Helium is unique from the other noble gases in that its concentration commonly increases along ground-water flow paths due to production of He in the subsurface. Helium-3 $\left({ }^{3} \mathrm{He}\right)$ is produced from the radioactive decay of tritium $\left({ }^{3} \mathrm{H}\right)$, an isotope produced naturally in the upper atmosphere. Atmospheric ${ }^{3} \mathrm{H}$ concentrations increased roughly a thousandfold throughout the northern hemisphere in the 1950s and early 1960s as a result of above-ground nuclear weapons testing. The radioactive decay of ${ }^{3} \mathrm{H}$ to ${ }^{3} \mathrm{He}$ is the basis of the ${ }^{3} \mathrm{H} /{ }^{3} \mathrm{He}$ ground-water dating method, the details of which are presented in Solomon and Cook (2000). ${ }^{3} \mathrm{H}$ has a half-life of 12.32 years. The component of ${ }^{3} \mathrm{He}$ in ground water produced from ${ }^{3} \mathrm{H}$ decay is termed "tritiogenic ${ }^{3} \mathrm{He}$ " $\left({ }^{3} \mathrm{He}_{\text {trit }}\right)$. Apparent ${ }^{3} \mathrm{H} /{ }^{3} \mathrm{He}$ ages are computed by determining the concentration of both ${ }^{3} \mathrm{H}$ and ${ }^{3} \mathrm{He}_{\text {trit }}$ in a sample and applying the known ${ }^{3} \mathrm{H}$ half-life. These ages are referred to as "apparent" because, 
for mixed samples containing water of different ages, they can differ from the true mean age of sampled water. Apparent ${ }^{3} \mathrm{H} /{ }^{3} \mathrm{He}$ ages were computed in this study for samples that were analyzed for ${ }^{3} \mathrm{H}$ and have ${ }^{3} \mathrm{H}$ concentrations $>1$ tritium unit (TU), where $1 \mathrm{TU}=1$ atom of ${ }^{3} \mathrm{H}$ per $10^{18}$ atoms of hydrogen. Such samples contain more than a small fraction of "modern" water, which recharged after the early 1950s. Reliable apparent ${ }^{3} \mathrm{H} /{ }^{3} \mathrm{He}$ ages cannot be determined for water recharged prior to the early 1950s ("pre-bomb" water) given the relatively short half-life of ${ }^{3} \mathrm{H}$. For samples that are mixtures of modern and pre-bomb water, the apparent ${ }^{3} \mathrm{H} /{ }^{3} \mathrm{He}$ age is approximately that of the modern component.

Helium can also accumulate in ground water because it is produced in the radioactive decay of $\mathrm{U}$ and $\mathrm{Th}$ in crustal rocks and aquifer solids ("crustal He"), and from upward diffusion/advection of primordial He from the mantle ("mantle $\mathrm{He}$ "). Together, crustal and mantle $\mathrm{He}$ are termed "terrigenic $\mathrm{He}$ " $\left(\mathrm{He}_{\text {terr }}\right)$. Details regarding $\mathrm{He}_{\text {terr }}$ are presented in Solomon (2000), and definitions of all He terms used in this report are listed in table 1. In general, $\mathrm{He}_{\text {terr }}$ is dominantly composed of crustal $\mathrm{He}$. Because $\mathrm{He}_{\text {terr }}$ concentrations usually increase with increasing residence time, $\mathrm{He}_{\text {terr }}$ has been used as a groundwater dating tool (assuming it is all crustal $\mathrm{He}$ ) for waters with residence times on the scale of $10^{3}-10^{4} \mathrm{yr}$. This method was not used in this study, because $\mathrm{He}_{\text {terr }}$ accumulation rates can vary widely and modeling them with confidence would require additional data. However, $\mathrm{He}_{\text {terr }}$ concentrations can still serve as an approximate relative age indicator. Crustal $\mathrm{He}$ can be distinguished from mantle $\mathrm{He}$ based on ${ }^{3} \mathrm{He} /{ }^{4} \mathrm{He}$ ratios. The ${ }^{3} \mathrm{He} /{ }^{4} \mathrm{He}$ ratio $(\mathrm{R})$ is typically expressed relative to the atmospheric ${ }^{3} \mathrm{He} /{ }^{4} \mathrm{He}$ ratio $\left(\mathrm{R}_{\mathrm{a}}\right)$ in the form $\mathrm{R} / \mathrm{R}_{\mathrm{a}}$. The $\mathrm{R} / \mathrm{R}_{\mathrm{a}}$ of crustal He is approximately 0.02 , whereas mantle He has an $\mathrm{R} / \mathrm{R}_{\mathrm{a}}$ of approximately $10-30$. The $\mathrm{R} / \mathrm{R}_{\mathrm{a}}$ of $\mathrm{He}_{\text {terr }}$ therefore can provide information on the relative amount of crustal versus mantle He accumulating in the ground water, with high levels of mantle He potentially indicating the upward migration of mantle fluids in the area.

\section{Sample Collection and Analysis}

Sample-site locations and information are provided in figure 5 and table 2. Samples were collected from wells and springs located in both the mountain block and basin-fill. Sampled well types include monitoring wells (including piezometers), supply wells (public, community, and commercial), and domestic wells. Samples were collected from wells using a dedicated pump, a submersible sampling pump, or an approximately 2.5 -m-long Kemmerer sampling bottle (a bailer designed to collect discrete-depth samples). The "nested piezometers" referred to throughout the rest of the report include SF2, SF6, SFR, ARCH1, and FAIR. Each nest has three piezometers denoted in the site name with an "A" (deepest), "B" (intermediate), or "C" (shallowest).

\section{Temperature Data}

Temperature profiles were measured in the summer of 2005 using a Mount Sopris model 2WQA-1000 downhole temperature/conductivity logging tool, having a rated precision of $\leq 0.01^{\circ} \mathrm{C}$. The tool was field-calibrated using two standards straddling the range of anticipated temperature measurements. Temperatures of the standards were determined using two hand-held probes, each with rated accuracy of $0.1{ }^{\circ} \mathrm{C}$. Temperatures were recorded at 6-cm-depth intervals. Logging rates were $1.5-3.0 \mathrm{~m} / \mathrm{min}$, and the tool was stopped for several $\mathrm{min}$ utes immediately after submersion at the water table to allow complete thermal equilibration. In addition to these profiles, some discrete down-hole temperature measurements were made at other locations using a YSI Model 85 handheld meter with a 30-m-long probe cable. The probe has a rated accuracy for temperature of $0.1^{\circ} \mathrm{C}$.

\section{Field Parameters}

Discharge temperature, dissolved oxygen concentration, and specific conductance were measured using a YSI Model 85 handheld probe. The probe has a rated accuracy of $0.1^{\circ} \mathrm{C}$ for temperature, $0.2 \mathrm{mg} / \mathrm{L}$ for dissolved oxygen, and 0.5 percent for specific conductance. Field $\mathrm{pH}$ was measured using a YSI model $\mathrm{pH} 100$ handheld probe, with a rated accuracy of 0.1 percent. Both probes were calibrated regularly according to the manufacturer's instructions. Field alkalinity (as $\mathrm{CaCO}_{3}$ ) was measured by titration using a LaMotte model WAT-DR field test kit, with an accuracy of approximately $4 \mathrm{ppm}$. For springs, field parameters were measured in the spring pool. For wells, field parameters were measured in a bucket filled with purge water at the time of sample collection.

\section{Major Ions and Trace Elements}

Samples were collected following stabilization of the field parameters. Purge volumes varied, but were usually 1-3 casing volumes for wells not regularly pumped (monitoring wells). Samples were collected in 125 -mL polyethylene bottles that were triple-rinsed with purge water prior to filling. All samples were stored on ice and in the dark until delivered to the laboratory.

Samples were filtered prior to analysis using a $0.45-\mu \mathrm{m}$ filter. Samples analyzed by LANL were filtered in the field, and samples for metal and major cation analyses were immediately acidified with analytical grade nitric acid to a $\mathrm{pH}$ of 2.0 or less. Samples analyzed by the New Mexico Bureau of Geology and Mineral Resources (NMBGMR) were not filtered and acidified in the field, but were transported to the laboratory for analysis within 24-36 hours of sample collection, then filtered in the laboratory. 


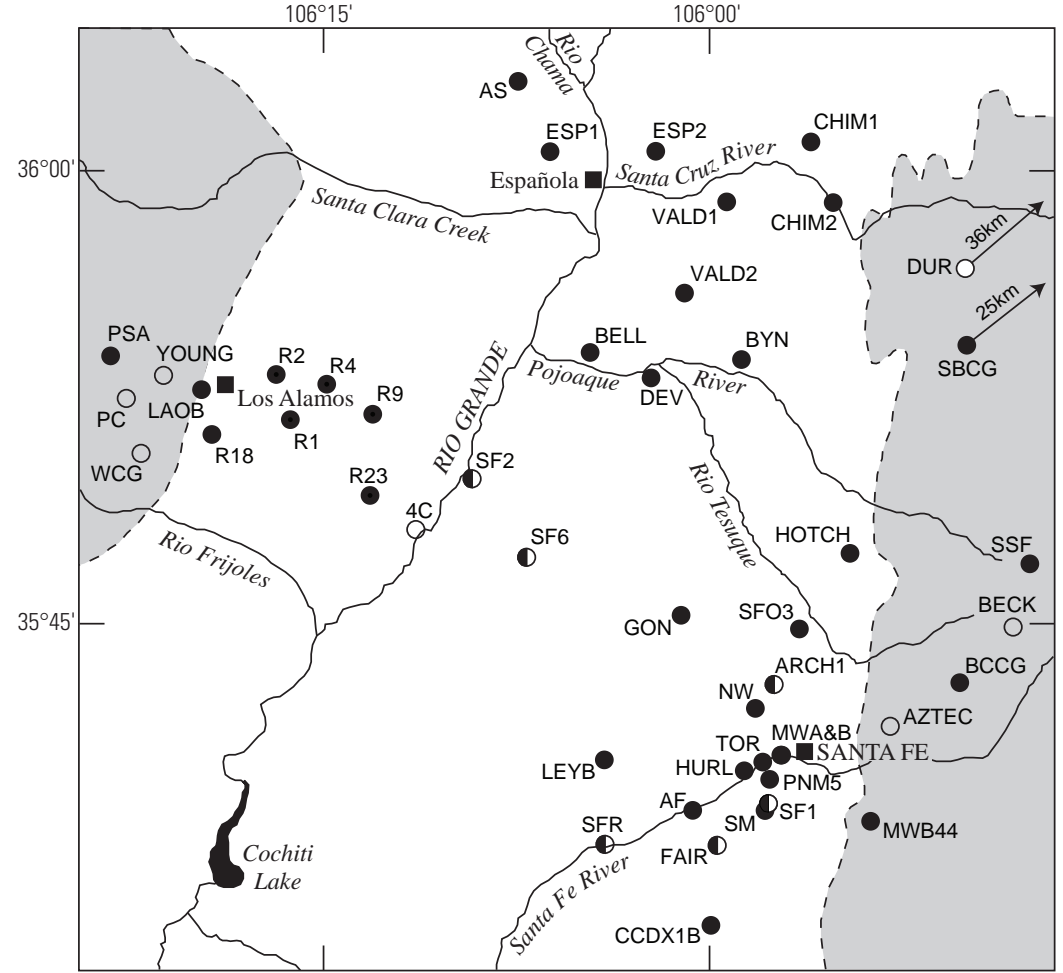

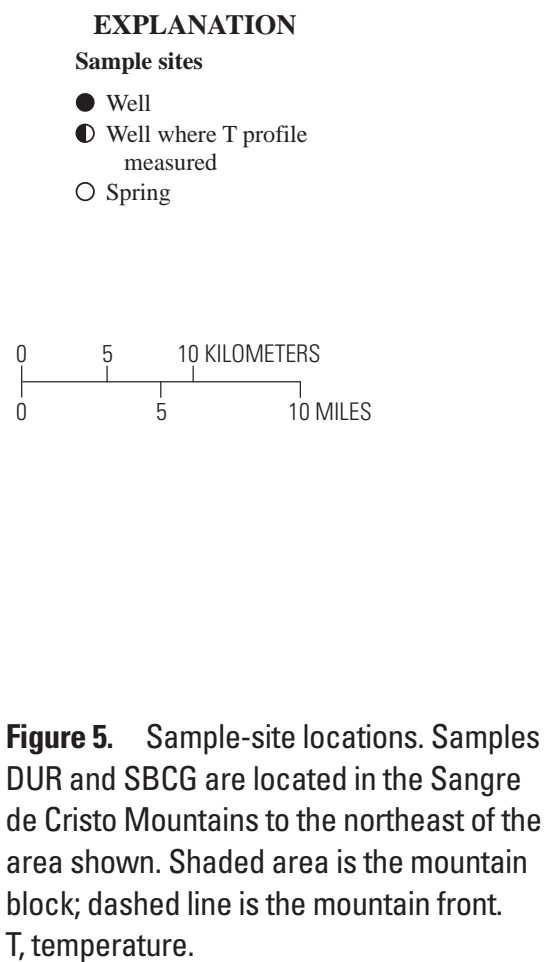

EXPLANATION

Sample sites

measure

Spring

Figure 5. Sample-site locations. Samples DUR and SBCG are located in the Sangre de Cristo Mountains to the northeast of the area shown. Shaded area is the mountain T, temperature.
Samples analyzed by LANL were analyzed at the EES-6 division laboratory using techniques specified in the U.S. Environmental Protection Agency SW-846 manual. Total carbonate alkalinity was determined using standard titration techniques. Ion chromatography (IC) was the analytical method for bromide $(\mathrm{Br})$, chloride $(\mathrm{Cl})$, fluoride $(\mathrm{F})$, nitrate $\left(\mathrm{NO}_{3}\right)$, nitrite $\left(\mathrm{NO}_{2}\right)$, and sulfate $\left(\mathrm{SO}_{4}\right)$. Inductively coupled (argon) plasma-optical emission spectroscopy (ICP-OES) was used for analyses of calcium $(\mathrm{Ca})$, magnesium $(\mathrm{Mg})$, potassium $(\mathrm{K})$, silica $\left(\mathrm{SiO}_{2}\right.$, calculated from silicon), and sodium (Na). Remaining trace elements were analyzed by inductively coupled (argon) plasma-mass spectrometry (ICP-MS). For samples analyzed by NMBGMR, alkalinity was determined by titration within 36 hours of sample collection. Major anion ions were analyzed by IC, major cations by ICP-OES, and trace elements by ICP-MS. Analytical error for major ions and trace elements is generally less than 10 percent using IC, ICP-OES, and ICP-MS.

\section{Oxygen-18 and Deuterium}

Samples for oxygen-18 $\left({ }^{18} \mathrm{O}\right)$ and deuterium $\left({ }^{2} \mathrm{H}\right)$ analyses were collected along with major ion and trace element samples at some sites, but they were not filtered. Samples analyzed by LANL (BECK'S SPRING, WLAOB-01, WR2-01, WR4-01, WR18-01, and WR23-01) were analyzed by the EES-6 division using isotope ratio-mass spectrometry (IR-MS). The remaining samples, collected from the nested piezometers, were analyzed at the New Mexico Institute of Mining and Technology Department of Earth and Environmental Sciences stable isotope laboratory by accelerator mass spectrometry. Analytical uncertainties for $\delta^{18} \mathrm{O}$ and $\delta^{2} \mathrm{H}$ are typically less than 0.1 per mil (\%o) and $1 \%$, respectively.

\section{Carbon Isotopes}

Carbon isotope samples were collected in 1-L safetycoated glass bottles with a silicon-teflon septum in the cap. After being triple-rinsed, the bottles were filled by inserting the discharge end of the sample line to the bottom of the bottle, and the bottle was allowed to overflow continuously until at least $2 \mathrm{~L}$ of water had flowed through the bottle. This method prevented contact between the sampled water and the atmosphere and insured that the bottle was thoroughly purged of air. Samples were filtered using an in-line $0.45-\mu \mathrm{m}$ filter, chilled, and stored in the dark prior to analysis.

$\delta^{13} \mathrm{C}$ and ${ }^{14} \mathrm{C}$ activity of DIC were measured at the University of Waterloo Environmental Isotope Laboratory by IR-MS and at the University of Arizona using accelerator mass spectrometry (AMS), respectively. Dissolved inorganic carbon was extracted from solution in the form of $\mathrm{CO}_{2}$ gas by acidification under vacuum by the University of Waterloo Environmental Isotope Laboratory, and the $\mathrm{CO}_{2}$ gas was sealed in glass breakseals. $\delta^{13} \mathrm{C}$ was determined for the $\mathrm{CO}_{2}$ gas on the Vienna Pee Dee Belemnite (VPDB) scale. One of the breakseals was then sent to the University of Arizona for graphite target preparation and ${ }^{14} \mathrm{C}$ measurement. Details regarding methods used by the University of Arizona AMS facility for ${ }^{14} \mathrm{C}$ determinations can be found in Donahue and others (1990). 
Table 2. Sample information.

[asl, above sea level; bgs, below ground surface; MI, major ions; TE, trace elements; NA, not applicable; U, undetermined; G, grab sample; P, pumped; B, bailed]

\begin{tabular}{|c|c|c|c|c|c|c|c|c|c|c|c|c|c|c|c|c|c|c|c|}
\hline \multirow[b]{2}{*}{$\begin{array}{l}\text { Site } \\
\text { name }\end{array}$} & \multirow{2}{*}{$\begin{array}{c}\text { Site } \\
\text { abbrevia- } \\
\text { tion }\end{array}$} & \multirow[b]{2}{*}{$\begin{array}{l}\text { Site } \\
\text { type }\end{array}$} & \multicolumn{2}{|c|}{$\begin{array}{c}\text { Location } \\
\text { (UTM, NAD 27) }\end{array}$} & \multirow{2}{*}{$\begin{array}{l}\text { Surface } \\
\text { elevation } \\
\text { (m asl) }\end{array}$} & \multirow{2}{*}{$\begin{array}{l}\text { Screen } \\
\text { bottom } \\
\text { (m bgs) }\end{array}$} & \multirow{2}{*}{$\begin{array}{c}\text { Screen } \\
\text { top } \\
\text { (m bgs) }\end{array}$} & \multirow{2}{*}{$\begin{array}{l}\text { Screen } \\
\text { length } \\
\text { (m) }\end{array}$} & \multicolumn{3}{|c|}{ Depth to water } & \multirow[b]{2}{*}{$\begin{array}{c}\text { Sample } \\
\text { name }^{2}\end{array}$} & \multirow{2}{*}{$\begin{array}{l}\text { Sample } \\
\text { date }\end{array}$} & \multirow{2}{*}{$\begin{array}{l}\text { Sample } \\
\text { depth }^{3} \\
\text { (m bgs) }\end{array}$} & \multirow{2}{*}{$\begin{array}{l}\text { Sample- } \\
\text { method }\end{array}$} & \multicolumn{4}{|c|}{$\begin{array}{c}\text { Samples collected } \\
\text { and analyzed }\end{array}$} \\
\hline & & & $\begin{array}{l}\text { Easting } \\
\text { (m) }\end{array}$ & $\begin{array}{l}\text { Northing } \\
\text { (m) }\end{array}$ & & & & & $\begin{array}{c}\text { Measure- } \\
\text { ment } \\
\text { (m bgs) }\end{array}$ & Date & $\begin{array}{l}\text { Source } \\
\text { notes }^{1}\end{array}$ & & & & & $\begin{array}{l}\text { Dis- } \\
\text { solved } \\
\text { gases }\end{array}$ & ${ }^{3} \mathrm{H}$ & $\begin{array}{c}\text { C } \\
\text { iso- } \\
\text { topes }\end{array}$ & $\begin{array}{c}\text { MI } \\
\text { and } \\
\text { TE }\end{array}$ \\
\hline PC Spring & $\mathrm{PC}$ & Spring & 375196 & 3970525 & 2689 & NA & NA & NA & NA & NA & NA & SPC-01 & 06/29/05 & NA & $\mathrm{G}$ & $\mathrm{x}$ & $\mathrm{x}$ & $\mathrm{x}$ & $\mathrm{x}$ \\
\hline WCG Spring & WCG & Spring & 376108 & 3967328 & 2449 & NA & NA & NA & NA & NA & NA & SWCG-01 & $10 / 07 / 04$ & NA & G & $\mathrm{x}$ & $\mathrm{x}$ & & \\
\hline Young's Spring & YOUNG & Spring & 377392 & 3971892 & 2372 & NA & NA & NA & NA & NA & NA & $\begin{array}{l}\text { SYOUNG-01 } \\
\text { SYOUNG-01R }\end{array}$ & $\begin{array}{l}07 / 01 / 05 \\
07 / 01 / 05\end{array}$ & $\begin{array}{l}\text { NA } \\
\text { NA }\end{array}$ & $\begin{array}{l}\text { G } \\
\text { G }\end{array}$ & $\mathrm{x}$ & $\begin{array}{l}\mathrm{x} \\
\mathrm{x}\end{array}$ & & \\
\hline Pajarito Ski Area & PSA & Supply well & 374170 & 3973116 & 2838 & 120 & 101 & 18 & 75 & $6 / 85$ & 2 & WPSA-01 & $10 / 06 / 04$ & 110 & $\mathrm{P}$ & $\mathrm{x}$ & $\mathrm{x}$ & & \\
\hline Beck’s Spring & BECK & Spring & 427222 & 3957104 & 3168 & NA & NA & NA & NA & & & BECK'S SPRING & 09/16/05 & NA & G & & & $\mathrm{x}$ & $\mathrm{x}$ \\
\hline Duran Spring & DUR & Spring & 457256 & 3998574 & 2712 & NA & NA & NA & NA & NA & NA & SDUR-01 & 09/08/05 & NA & G & $\mathrm{x}$ & $\mathrm{x}$ & & \\
\hline Aztec Spring & AZTEC & Spring & 420015 & 3951255 & 2333 & NA & NA & NA & NA & NA & NA & $\begin{array}{l}\text { SAZTEC-01 } \\
\text { SAZTEC-02 }\end{array}$ & $\begin{array}{l}10 / 08 / 04 \\
09 / 09 / 05\end{array}$ & $\begin{array}{l}\text { NA } \\
\text { NA }\end{array}$ & $\begin{array}{l}\text { G } \\
G\end{array}$ & $\begin{array}{l}\mathrm{x} \\
\mathrm{x}\end{array}$ & $\begin{array}{l}\mathrm{x} \\
\mathrm{x}\end{array}$ & & \\
\hline Ski Santa Fe & SSF & Supply well & 428219 & 3960881 & 3240 & 43 & 30 & 12 & 2 & $\mathrm{U}$ & 8 & WSSF-01 & $10 / 08 / 04$ & 37 & $\mathrm{P}$ & $\mathrm{x}$ & $\mathrm{x}$ & & \\
\hline $\begin{array}{l}\text { Santa Barbara } \\
\text { Campground }\end{array}$ & SBCG & Supply well & 445029 & 3993644 & 2732 & 52 & 37 & 15 & 14 & $5 / 96$ & 2 & WSBCG-01 & 09/08/05 & 44 & $\mathrm{P}$ & $\mathrm{x}$ & $\mathrm{x}$ & & \\
\hline $\begin{array}{l}\text { Black Cyn } \\
\text { Campground }\end{array}$ & BCCG & Supply well & 424099 & 3953888 & 2531 & 24 & $\mathrm{U}$ & $\mathrm{U}$ & 2 & $\mathrm{U}$ & 8 & WBCCG-01 & $10 / 06 / 04$ & 13 & $\mathrm{P}$ & $\mathrm{x}$ & $\mathrm{x}$ & & \\
\hline MWB \#44 & MWB44 & Domestic well & 418856 & 3945731 & 2319 & 48 & 32 & 15 & 25 & 1990 & 4 & WMWB44-01 & $06 / 30 / 05$ & 40 & $\mathrm{P}$ & $\mathrm{x}$ & $\mathrm{x}$ & $\mathrm{x}$ & $\mathrm{x}$ \\
\hline Agua Sana \#1 & AS & Supply well & 398130 & 3989271 & 1854 & 375 & 235 & 140 & 144 & $8 / 98$ & 2 & $\begin{array}{l}\text { WAS1-01 } \\
\text { WAS1-01R }\end{array}$ & $\begin{array}{l}06 / 24 / 05 \\
06 / 24 / 05\end{array}$ & $\begin{array}{l}305 \\
305\end{array}$ & $\begin{array}{l}\mathrm{P} \\
\mathrm{P}\end{array}$ & $\begin{array}{l}\mathrm{x} \\
\mathrm{x}\end{array}$ & & $\begin{array}{l}x \\
x\end{array}$ & $\mathrm{x}$ \\
\hline Española West & ESP1 & Supply well & 400008 & 3985133 & 1798 & 229 & 137 & 91 & 109 & 2005 & 2 & WESP1-01 & 06/09/05 & 183 & $\mathrm{P}$ & $\mathrm{x}$ & & $\mathrm{x}$ & $\mathrm{x}$ \\
\hline Española East & ESP2 & Supply well & 406223 & 3985156 & 1743 & 204 & 61 & 143 & -5 & 2005 & 2 & WESP2-01 & 06/09/05 & 133 & $\mathrm{P}$ & $\mathrm{x}$ & & $\mathrm{x}$ & $\mathrm{x}$ \\
\hline Spring 4C & $4 \mathrm{C}$ & Spring & 392241 & 3962800 & 1675 & NA & NA & NA & NA & NA & NA & S4C-01 & $10 / 08 / 04$ & NA & G & $\mathrm{x}$ & $\mathrm{x}$ & & \\
\hline LAOB & LAOB & Monitoring well & 379515 & 3971129 & 2233 & 8 & 4 & 5 & 2 & $8 / 17 / 05$ & 1 & WLAOB-01 & 08/17/05 & 6 & $\mathrm{P}$ & $\mathrm{x}$ & $\mathrm{x}$ & $\mathrm{x}$ & $\mathrm{x}$ \\
\hline R1 & R1 & Monitoring well & 384737 & 3969365 & 2098 & 322 & 314 & 8 & 306 & $9 / 12 / 05$ & 1 & WR1-01 & 09/12/05 & 318 & $\mathrm{P}$ & $\mathrm{x}$ & $\mathrm{x}$ & & \\
\hline R2 & R2 & Monitoring well & 383907 & 3972021 & 2064 & 283 & 276 & 7 & 274 & $8 / 9 / 05$ & 1 & WR2-01 & 08/09/05 & 280 & $\mathrm{P}$ & $\mathrm{x}$ & $\mathrm{x}$ & $\mathrm{x}$ & $\mathrm{x}$ \\
\hline R4 & R4 & Monitoring well & 386877 & 3971449 & 2005 & 249 & 242 & 7 & 227 & $8 / 8 / 05$ & 1 & WR4-01 & 08/08/05 & 245 & $\mathrm{P}$ & $\mathrm{x}$ & $\mathrm{x}$ & $\mathrm{x}$ & $\mathrm{x}$ \\
\hline R9 & R9 & Monitoring well & 389582 & 3969683 & 1946 & 228 & 208 & 20 & 211 & $8 / 16 / 05$ & 1 & WR9-01 & 08/16/05 & 218 & $\mathrm{P}$ & $\mathrm{x}$ & $\mathrm{x}$ & & \\
\hline R18 & R18 & Monitoring well & 380123 & 3968492 & 2258 & 421 & 414 & 7 & 393 & $8 / 25 / 05$ & 1 & WR18-01 & 08/25/05 & 418 & $\mathrm{P}$ & $\mathrm{x}$ & $\mathrm{x}$ & $\mathrm{x}$ & $\mathrm{x}$ \\
\hline R23 & R23 & Monitoring well & 389422 & 3964905 & 1990 & 266 & 249 & 17 & 253 & $8 / 15 / 05$ & 1 & WR23-01 & 08/15/05 & 257 & $\mathrm{P}$ & $\mathrm{x}$ & $\mathrm{x}$ & $\mathrm{x}$ & $\mathrm{x}$ \\
\hline $\begin{array}{l}\text { Chimayo } \\
\text { MDWCA \#1 }\end{array}$ & CHIM1 & Monitoring well & 415346 & 3985706 & 1895 & 122 & 61 & 61 & 38 & $6 / 16 / 05$ & 1 & WCHIM1-01 & $06 / 16 / 05$ & 105 & B & $\mathrm{x}$ & $\mathrm{x}$ & $\mathrm{x}$ & $\mathrm{x}$ \\
\hline $\begin{array}{l}\text { Chimayo } \\
\text { MDWCA \#2 }\end{array}$ & CHIM2 & Monitoring well & 416654 & 3982136 & 1884 & 15 & $\mathrm{U}$ & $\mathrm{U}$ & 3 & $6 / 16 / 05$ & 1 & WCHIM2-01 & 06/16/05 & 9 & $\mathrm{P}$ & $\mathrm{x}$ & $\mathrm{x}$ & $\mathrm{x}$ & $\mathrm{x}$ \\
\hline $\begin{array}{l}\text { Valdez \#1 } \\
\qquad \text { (La Puebla) }\end{array}$ & VALD1 & Domestic well & 410394 & 3982178 & 1802 & 61 & $\mathrm{U}$ & $\mathrm{U}$ & 27 & 1997 & 3 & WVALD1-01 & 06/09/05 & 44 & $\mathrm{P}$ & $\mathrm{x}$ & $\mathrm{x}$ & $\mathrm{x}$ & $\mathrm{x}$ \\
\hline $\begin{array}{l}\text { Valdez \#2 } \\
\text { (Arroyo Seco) }\end{array}$ & VALD2 & Domestic well & 407913 & 3976812 & 1815 & 108 & $\mathrm{U}$ & $\mathrm{U}$ & 37 & 2005 & 5 & WVALD2-01 & 06/09/05 & 73 & $\mathrm{P}$ & $\mathrm{x}$ & $\mathrm{x}$ & $\mathrm{x}$ & $\mathrm{x}$ \\
\hline Devereux & DEV & Domestic well & 405947 & 3971820 & 1760 & 55 & $\mathrm{U}$ & $\mathrm{U}$ & 12 & 2000 & 2 & WDEV-01 & 06/06/05 & 34 & $\mathrm{P}$ & $\mathrm{x}$ & $\mathrm{x}$ & $\mathrm{x}$ & $\mathrm{x}$ \\
\hline Bynum & BYN & Domestic well & 411263 & 3972901 & 1838 & 91 & $\mathrm{U}$ & $\mathrm{U}$ & 10 & 1980 & 7 & WBYN-01 & 06/28/05 & 51 & $\mathrm{P}$ & $\mathrm{x}$ & $\mathrm{x}$ & $\mathrm{x}$ & $\mathrm{x}$ \\
\hline Bell & BELL & Domestic well & 402363 & 3973318 & 1731 & 53 & $\mathrm{U}$ & $\mathrm{U}$ & 27 & 1987 & 7 & WBELL-01 & 06/10/05 & 40 & $\mathrm{P}$ & $\mathrm{x}$ & $\mathrm{x}$ & $\mathrm{x}$ & $\mathrm{x}$ \\
\hline SF2B & SF2B & Monitoring well & 395434 & 3965883 & 1683 & 248 & 245 & 3 & 52 & $3 / 05$ & 6 & WSF2B & 04/05/05 & 246 & $\mathrm{P}$ & $\mathrm{x}$ & & & \\
\hline $\mathrm{SF} 2 \mathrm{C}$ & $2 \mathrm{C}$ & Monit & 395434 & 3965883 & & 102 & 99 & 3 & 58 & $3 / 05$ & 6 & $\begin{array}{l}\text { WSF2B } \\
\text { WSF2C }\end{array}$ & $\begin{array}{l}04 / 06 / 05 \\
04 / 06 / 05\end{array}$ & $\begin{array}{l}246 \\
100\end{array}$ & $\begin{array}{l}\mathrm{P} \\
\mathrm{P}\end{array}$ & $\mathrm{x}$ & $\mathrm{x}$ & $\begin{array}{l}x \\
x\end{array}$ & $\begin{array}{l}x \\
x\end{array}$ \\
\hline SF6A & SF6A & Monitoring well & 398635 & 3961265 & 1819 & 741 & 732 & 9 & 37 & $3 / 05$ & 6 & WSF6A & 03/29/05 & 736 & $\mathrm{P}$ & $\hat{x}$ & & & x \\
\hline
\end{tabular}


Table 2. Sample information.-Continued

[asl, above sea level; bgs, below ground surface; MI, major ions; TE, trace elements; NA, not applicable; U, undetermined; G, grab sample; P, pumped; B, bailed]

\begin{tabular}{|c|c|c|c|c|c|c|c|c|c|c|c|c|c|c|c|c|c|c|c|}
\hline \multirow[b]{2}{*}{$\begin{array}{c}\text { Site } \\
\text { name }\end{array}$} & \multirow{2}{*}{$\begin{array}{c}\text { Site } \\
\text { abbrevia- } \\
\text { tion }\end{array}$} & \multirow[b]{2}{*}{$\begin{array}{l}\text { Site } \\
\text { type }\end{array}$} & \multicolumn{2}{|c|}{$\begin{array}{c}\text { Location } \\
\text { (UTM, NAD 27) }\end{array}$} & \multirow{2}{*}{$\begin{array}{c}\text { Surface } \\
\text { elevation } \\
\text { (m asl) }\end{array}$} & \multirow{2}{*}{$\begin{array}{l}\text { Screen } \\
\text { bottom } \\
\text { (m bgs) }\end{array}$} & \multirow{2}{*}{$\begin{array}{c}\text { Screen } \\
\text { top } \\
\text { (m bgs) }\end{array}$} & \multirow{2}{*}{$\begin{array}{l}\text { Screen } \\
\text { length } \\
\text { (m) }\end{array}$} & \multicolumn{3}{|c|}{ Depth to water } & \multirow[b]{2}{*}{$\begin{array}{c}\text { Sample } \\
\text { name }^{2}\end{array}$} & \multirow{2}{*}{$\begin{array}{c}\text { Sample } \\
\text { date }\end{array}$} & \multirow{2}{*}{$\begin{array}{l}\text { Sample } \\
\text { depth }^{3} \\
\text { (m bgs) }\end{array}$} & \multirow{2}{*}{$\begin{array}{l}\text { Sample } \\
\text { method }\end{array}$} & \multicolumn{4}{|c|}{$\begin{array}{l}\text { Samples collected } \\
\text { and analyzed }\end{array}$} \\
\hline & & & $\begin{array}{l}\text { Easting } \\
\text { (m) }\end{array}$ & $\begin{array}{l}\text { Northing } \\
\text { (m) }\end{array}$ & & & & & $\begin{array}{c}\text { Measure- } \\
\text { ment } \\
\text { (m bgs) }\end{array}$ & Date & $\begin{array}{l}\text { Source } \\
\text { notes }^{1}\end{array}$ & & & & & $\begin{array}{l}\text { Dis- } \\
\text { solved } \\
\text { gases }\end{array}$ & ${ }^{3} \mathrm{H}$ & $\begin{array}{c}\text { C } \\
\text { iso- } \\
\text { topes }\end{array}$ & $\begin{array}{c}\mathrm{MI} \\
\text { and } \\
\mathrm{TE}\end{array}$ \\
\hline & & & & & & & & & & & & WSF6A & 03/30/05 & 736 & $\mathrm{P}$ & & & $\mathrm{x}$ & \\
\hline SF6B & SF6B & Monitoring well & 398635 & 3961265 & 1819 & 405 & 396 & 9 & 56 & $3 / 05$ & 6 & WSF6B & 03/30/05 & 401 & $\mathrm{P}$ & $\mathrm{x}$ & & $\mathrm{x}$ & $\mathrm{x}$ \\
\hline SF6C & SF6C & Monitoring well & 398635 & 3961265 & 1819 & 143 & 85 & 58 & 58 & $3 / 05$ & 6 & WSF6C & 04/06/05 & 114 & $\mathrm{P}$ & $\mathrm{x}$ & $\mathrm{x}$ & $\mathrm{x}$ & $\mathrm{x}$ \\
\hline SF River A & SFRA & Monitoring well & 403248 & 3944370 & 1940 & 579 & 573 & 6 & 64 & $3 / 05$ & 6 & WSFRA & 04/08/05 & 576 & $\mathrm{P}$ & $\mathrm{x}$ & & $\mathrm{x}$ & $\mathrm{x}$ \\
\hline SF River B & SFRB & Monitoring well & 403248 & 3944370 & 1940 & 325 & 319 & 6 & 62 & $3 / 05$ & 6 & WSFRB & 04/08/05 & 322 & $\mathrm{P}$ & $\mathrm{x}$ & & $\mathrm{x}$ & $\mathrm{x}$ \\
\hline SF River C & SFRC & Monitoring well & 403248 & 3944370 & 1940 & 183 & 177 & 6 & 56 & $3 / 05$ & 6 & WSFRC & 04/09/05 & 180 & $\mathrm{P}$ & $\mathrm{x}$ & $\mathrm{x}$ & $\mathrm{x}$ & $\mathrm{x}$ \\
\hline Fairgrounds A & FAIRA & Monitoring well & 409839 & 3944303 & 2028 & 515 & 512 & 3 & 63 & $2 / 05$ & 6 & WFAIRA-01 & 04/07/05 & 514 & $\mathrm{P}$ & $\mathrm{x}$ & & $\mathrm{x}$ & $\mathrm{x}$ \\
\hline Fairgrounds B & FAIRB & Monitoring well & 409839 & 3944303 & 2028 & 418 & 415 & 3 & 58 & $2 / 05$ & 6 & WFAIRB-01 & 04/07/05 & 416 & $\mathrm{P}$ & $\mathrm{x}$ & & $\mathrm{x}$ & $\mathrm{x}$ \\
\hline \multirow[t]{2}{*}{ Fairgrounds C } & FAIRC & Monitoring well & 409839 & 3944303 & 2028 & 162 & 101 & 61 & 48 & $2 / 05$ & 6 & WFAIRC-01 & 03/31/05 & 131 & $\mathrm{P}$ & & & $\mathrm{x}$ & $\mathrm{x}$ \\
\hline & & & & & & & & & & & & WFAIRC-01 & $06 / 14 / 05$ & 131 & $\mathrm{P}$ & $\mathrm{x}$ & $\mathrm{x}$ & & \\
\hline \multirow[t]{2}{*}{ Archery 1A } & ARCH1A & Monitoring well & 413195 & 3953775 & 2194 & 332 & 329 & 3 & 149 & $3 / 05$ & 6 & WARCH1A-01 & 04/04/05 & 331 & $\mathrm{P}$ & & & $\mathrm{x}$ & $\mathrm{x}$ \\
\hline & & & & & & & & & & & & WARCH1A-01 & 06/13/05 & 331 & B & $\mathrm{x}$ & $\mathrm{x}$ & & \\
\hline Archery 1B & ARCH1B & Monitoring well & 413195 & 3953775 & 2194 & 277 & 274 & 3 & 151 & $3 / 05$ & 6 & WARCH1B-01 & $04 / 05 / 05$ & 276 & $\mathrm{P}$ & & & $\mathrm{x}$ & $\mathrm{x}$ \\
\hline Archery 1C & ARCH1C & Monitoring well & 413195 & 3953775 & 2194 & 200 & 154 & 46 & 157 & $3 / 05$ & 6 & WARCH1C-01 & $04 / 04 / 05$ & 177 & $\mathrm{P}$ & & & $\mathrm{x}$ & $\mathrm{x}$ \\
\hline CCDX1B & CCDX1B & Monitoring well & 409466 & 3939609 & 2000 & 271 & 210 & 61 & 75 & 2001 & 2 & WCCDX1B-01 & $06 / 15 / 05$ & 259 & B & $\mathrm{x}$ & $\mathrm{x}$ & $\mathrm{x}$ & $\mathrm{x}$ \\
\hline MWA & MWA & Monitoring well & 413576 & 3949625 & 2100 & 11 & 8 & 3 & 9 & $6 / 14 / 05$ & 1 & WMWA-01 & $06 / 14 / 05$ & 11 & $\mathrm{P}$ & $\mathrm{x}$ & $\mathrm{x}$ & $\mathrm{x}$ & $\mathrm{x}$ \\
\hline \multirow[t]{2}{*}{ MWB } & MWB & Monitoring well & 413626 & 3949626 & 2102 & 9 & 5 & 5 & 5 & $6 / 30 / 05$ & 1 & WMWB-01 & 08/08/05 & 9 & B & $\mathrm{x}$ & $\mathrm{x}$ & & \\
\hline & & & & & & & & & & & & WMWB-02 & 09/07/05 & 9 & $\mathrm{P}$ & & & $\mathrm{x}$ & $\mathrm{x}$ \\
\hline \multirow[t]{4}{*}{ Saint Mike’s } & SM & Supply well & 412648 & 3946363 & 2094 & 238 & 116 & 122 & 66 & 1983 & 2 & WSM-01 & 10/07/04 & 177 & $\mathrm{P}$ & $\mathrm{x}$ & $\mathrm{x}$ & & \\
\hline & & & & & & & & & & & & WSM-02 & 06/08/05 & 177 & $P$ & $\mathrm{x}$ & $\mathrm{x}$ & & \\
\hline & & & & & & & & & & & & WSM-02R & 06/08/05 & 177 & $\mathrm{P}$ & $\mathrm{x}$ & $\mathrm{x}$ & & \\
\hline & & & & & & & & & & & & WSM-03 & 06/23/05 & 177 & $\mathrm{P}$ & $\mathrm{x}$ & & $\mathrm{x}$ & $\mathrm{x}$ \\
\hline \multirow[t]{2}{*}{ Northwest } & NW & Supply well & 412080 & 3952375 & 2170 & 604 & 152 & 451 & 124 & 1998 & 2 & WNW-01 & $10 / 07 / 04$ & 378 & $\mathrm{P}$ & $\mathrm{x}$ & $\mathrm{x}$ & & \\
\hline & & & & & & & & & & & & WNW-02 & 06/30/05 & 378 & $\mathrm{P}$ & & & $\mathrm{x}$ & $\mathrm{x}$ \\
\hline \multirow[t]{2}{*}{ Torreon } & TOR & Supply well & 412513 & 3949216 & 2080 & 366 & 122 & 244 & 64 & 1997 & 2 & WTOR-01 & 06/08/05 & 244 & $\mathrm{P}$ & $\mathrm{x}$ & $\mathrm{x}$ & & \\
\hline & & & & & & & & & & & & WTOR-02 & 06/30/05 & 244 & $\mathrm{P}$ & & & $\mathrm{x}$ & $\mathrm{x}$ \\
\hline PNM5 & PNM5 & Supply well & 412921 & 3948199 & 2097 & 134 & 90 & 44 & 92 & 2004 & 2 & WPNM5-01 & 10/07/04 & 113 & $\mathrm{P}$ & $\mathrm{x}$ & $\mathrm{x}$ & & \\
\hline \multirow[t]{2}{*}{ Agua Fria } & $\mathrm{AF}$ & Supply well & 408396 & 3946375 & 2014 & 85 & 73 & 12 & 30 & 2002 & 2 & WAF-01 & 06/08/05 & 79 & $\mathrm{P}$ & $\mathrm{x}$ & $\mathrm{x}$ & $\mathrm{x}$ & $\mathrm{x}$ \\
\hline & & & & & & & & & & & & WAF-01R & 06/08/05 & 79 & $\mathrm{P}$ & & & $\mathrm{x}$ & \\
\hline $\begin{array}{l}\text { Santa Fe } \\
\quad \text { Opera \#3 }\end{array}$ & SFO3 & Supply well & 414669 & 3957048 & 2110 & 273 & 249 & 24 & 32 & $5 / 29 / 03$ & 4 & WSFO3-01 & 06/07/05 & 261 & $\mathrm{P}$ & $\mathrm{x}$ & $\mathrm{x}$ & $\mathrm{x}$ & $\mathrm{x}$ \\
\hline Hurlocker & HURL & Domestic well & 411425 & 3948702 & 2077 & 107 & $\mathrm{U}$ & $\mathrm{U}$ & 21 & 1980 & 7 & WHURL-01 & 07/01/05 & 64 & $\mathrm{P}$ & $\mathrm{x}$ & $\mathrm{x}$ & $\mathrm{x}$ & $\mathrm{x}$ \\
\hline Hotchkiss & НОТСH & Domestic well & 417644 & 3961498 & 2174 & 213 & 183 & 30 & 91 & 2002 & 4 & WHOTCH-01 & 06/28/05 & 198 & $\mathrm{P}$ & $\mathrm{x}$ & $\mathrm{x}$ & $\mathrm{x}$ & $\mathrm{x}$ \\
\hline Leyba & LEYB & Domestic well & 403198 & 3949345 & 1982 & 260 & 181 & 79 & 124 & $5 / 14 / 03$ & 4 & WLEYB-01 & 06/07/05 & 221 & $\mathrm{P}$ & $\mathrm{x}$ & & $\mathrm{x}$ & $\mathrm{x}$ \\
\hline Gonzales & GON & Domestic well & 407711 & 3957854 & 2014 & 234 & 195 & 39 & 115 & $7 / 30 / 03$ & 4 & WGON-01 & $06 / 10 / 05$ & 214 & $\mathrm{P}$ & $\mathrm{x}$ & & $\mathrm{x}$ & $\mathrm{x}$ \\
\hline
\end{tabular}

${ }^{1}$ Source notes: 1 = measured at time of sampling; $2=$ owner's information (for example, well completion report); $3=$ Office of the State Engineer's database; $4=$ New Mexico Bureau of Geology and Mineral Resources database; 5 = U.S. Geological Survey, New Mexico Water Science Center database; $6=$ measurement by U.S. Geological Survey, New Mexico Water Science Center; $7=$ estimate based on records for nearby wells in Office of the State Engineer's database; $8=$ estimate based on nearby spring.

${ }^{2}$ Sample names ending with "R" are replicate samples.

${ }^{3}$ For pumped samples, sampling depth considered to be depth of screen mid-point; for wells with unknown screen top depth, sampling depth considered to be mid-point between water table and screen bottom. 
Analytical error for $\delta^{13} \mathrm{C}$ is $0.3 \%$ or better. Two replicate samples were collected for C isotopes, WAS1-01R and WAF-01R.

All ${ }^{14} \mathrm{C}$ activity measurements are reported as the ${ }^{14} \mathrm{C}$ activity ratio, ${ }^{14} a$, expressed in percent modern carbon (pmC) at the time of sampling, not normalized for ${ }^{13} \mathrm{C}$ fractionation, and defined as

where

$$
\text { pmC }={ }^{14} \alpha \times 100=\left(\frac{{ }^{14} A_{\text {sample }}}{{ }^{14} A_{\text {reference }}}\right) \times 100
$$

${ }^{14} A_{\text {sample }}$

and

${ }^{14} A_{\text {reference }}$ is the absolute (specific) ${ }^{14} \mathrm{C}$ activity of the sample (in disintegrations per minute per gram of carbon),

is the standard activity defined as 95 percent of the activity of National Bureau of Standards oxalic acid (Ox 1) in the year A.D. 1950.

Further explanation of these reporting units in comparison to other common reporting units for ${ }^{14} \mathrm{C}$ activity measurements is provided by Plummer and others (2004a).

\section{Dissolved Gases and ${ }^{3} \mathrm{H}$}

Tritium samples were collected in 500-mL HDPE bottles (no filtration) that were triple-rinsed prior to filling. Most dissolved gas samples were collected in 3/8-in.-diameter copper tubing, following the guidelines in Stute and Schlosser (2000). Water was sealed in the copper tubing with stainless steel pinch-off clamps. Samples were collected using a flowthrough sampling line that prevented contact between the sampled water and air. Valves in the sample line regulated pressure provided by the pump (or the 2.5-m-high column of water in the Kemmerer bottle for bailed samples) such that back pressure was maintained on the sampled water at all times to prevent degassing. A peristaltic pump was used for spring samples. The sample tube was held in a vertical position and tapped repeatedly upon initiation of flow through the sample line to ensure that all air had been displaced from the tube. The sample line was carefully monitored thereafter to ensure that no bubbles appeared, indicating degassing. Four of the dissolved gas samples were collected in passive diffusion samplers similar to those described by Sanford and others (1996). The diffusion samplers are in situ sampling devices consisting of a 5-cm-long section of $0.5-\mathrm{cm}$-diameter copper tubing sealed at one end and connected to a sealed section of 0.5-cm-diameter silicone tubing at the other. Samplers were placed in the water and left for at least 48 hours, allowing dissolved gases in the water to equilibrate with the sampler headspace by diffusion through the silicone tubing. Samplers were then removed from the water and sealed using a cold-weld tool.
Tritium analyses were performed by the U.S. Geological Survey (USGS) Noble Gas Laboratory in Lakewood, Colo., using the ${ }^{3} \mathrm{He}$ in-growth method (Bayer and others, 1989). Approximately $170 \mathrm{~mL}$ of sample was placed in a tritium extraction flask, degassed for 30 minutes under vacuum while being agitated using a heated ultrasonic bath, then sealed using a cold-welded crimp. The flask was then stored for approximately 100 days, allowing for the accumulation of tritiogenically produced ${ }^{3} \mathrm{He}$. The flask was then attached to an ultra-high-vacuum extraction line, and the accumulated ${ }^{3} \mathrm{He}$ was released and purified prior to being measured using a magnetic sector mass spectrometer (Mass Analyzer Products 215-50). The ${ }^{3} \mathrm{He}$ concentration was determined by calibration to a known air standard run in conjunction with the sample set. The original ${ }^{3} \mathrm{H}$ concentration at the time of sampling was calculated from the measured ${ }^{3} \mathrm{He}$ concentration using the known decay constant $\left(0.05621 \mathrm{yr}^{-1}\right.$; Lucas and Unterweger, 2000) and the amount of time the extracted flask was stored.

Dissolved gas samples were analyzed by either the USGS Noble Gas Laboratory or the University of Utah Noble Gas Laboratory. For samples analyzed by the USGS, gases were extracted from the copper tube samples on an ultra-highvacuum extraction line. Gas extraction was not necessary for the diffusion samplers, for which gas extraction is essentially performed in situ. Major component gases (including $\mathrm{N}_{2}$ ) were measured on a quadrupole mass spectrometer in dynamic operation mode. Major component gases were then removed by chemical reaction with a heated titanium/ zirconium sponge, and remaining noble gases were separated cryogenically. Noble gas concentrations and isotopic compositions $\left(\mathrm{He},{ }^{3} \mathrm{He} /{ }^{4} \mathrm{He}\right.$ ratio, $\mathrm{Ne}, \mathrm{Ar}, \mathrm{Kr}$, and $\mathrm{Xe}$ ) were measured using separate aliquots on a magnetic sector mass spectrometer (Mass Analyzer Products 215-50) run in static operation mode. Gas concentrations were determined by calibration to a known air standard. Analytical procedures used by the University of Utah Noble Gas Laboratory were the same as those used by the USGS laboratory, except that Ne, Ar, Kr, and Xe were measured on the quadrupole mass spectrometer in static operation mode, and $\mathrm{Ar}, \mathrm{Kr}$, and $\mathrm{Xe}$ were measured by isotope dilution.

The detection limit for ${ }^{3} \mathrm{H}$ is approximately $0.05 \mathrm{TU}$. Analytical uncertainty $(1 \sigma)$ ranges from 0.05 TU at low concentrations ( $\leq 1 \mathrm{TU})$ to $0.2 \mathrm{TU}$ at higher concentrations ( $\geq 5 \mathrm{TU})$. For dissolved gases measured at the USGS laboratory, analytical uncertainties $(1 \sigma)$ are 2 percent for nitrogen, 1 percent for $\mathrm{He}, 1$ percent for the ${ }^{3} \mathrm{He} /{ }^{4} \mathrm{He}$ ratio, 3 percent for $\mathrm{Ne}, 2$ percent for $\mathrm{Ar}, 3$ percent for $\mathrm{Kr}$, and 3 percent for Xe. For dissolved gases measured at the University of Utah Laboratory, analytical uncertainties $(1 \sigma)$ are 3 percent for nitrogen, 2 percent for $\mathrm{He}, 1$ percent for the ${ }^{3} \mathrm{He} /{ }^{4} \mathrm{He}$ ratio, 3 percent for $\mathrm{Ne}, 3$ percent for Ar, 5 percent for $\mathrm{Kr}$, and 5 percent for Xe. Two replicate samples were collected, WAS1-01R and WSM-02R. 


\section{Results}

Figures in this section showing lateral distributions of data and computed values exclude samples from the deeper piezometers (SF2B, SF6A and B, SFRA and B, FAIRA and $\mathrm{B}, \mathrm{ARCH} 1 \mathrm{~A}$ and $\mathrm{B}$ ), which generally have mid-screen depths $>180 \mathrm{~m}$ below the water table (table 2). Samples shown in these figures are from wells with mid-screen depths generally $<180 \mathrm{~m}$ below the water table (table 2), and therefore illustrate lateral variations in the upper portion of the saturated zone only. It should be recognized, however, that the considerable majority of water utilized in the Española Basin is produced from this upper portion of the saturated zone. Vertical distributions can only be evaluated in the southeastern part of the basin where the nested piezometers are located because these are the only wells sampled with short, deep screened intervals (table 2). Given the limited data coverage, the following description of results focuses mostly on well-defined, firstorder spatial patterns and correlations between measurements.

\section{Temperature Profiles}

Temperature profiles were measured in the deepest piezometer in each of the sampled piezometer nests in the southeastern part of the basin (fig. 6). A scarcity of open wells (free of dedicated pumps) prevented the collection of more temperature profiles. The profiles step to the right on figure 6 with increasing distance from the mountain front, suggesting that ground water generally becomes warmer with distance from the mountain front. This warming probably is due to the ground elevation decreasing (thus $\mathrm{T}_{\mathrm{a}}$ increasing) with distance from the mountain front. It may also be due in part to ground water warming as it flows laterally from the mountain front to the Rio Grande.

Four of the six profiles (SF1A, FAIRA, SFRA, and SF2B) are clearly nonlinear, consistent with vertical groundwater flow rates greater than about $1 \mathrm{~cm} / \mathrm{yr}$ in the vicinity of these wells. Of these nonlinear profiles, the two closest to the mountain front (SF1A and FAIRA) are concave upward indicating downflow, and the two farther from the mountain front (SFRA and SF2B) are concave downward indicating upflow. The profiles also become generally less steep (temperatures warm more rapidly with depth) at great distances from the mountain front. The curvature patterns and gradient trends displayed by the profiles are thus consistent with ground water recharging near the mountain front and flowing westward to the Rio Grande. Profiles from ARCH1A and SF6A are relatively linear, suggesting little vertical ground-water flow in these locations. All profiles are relatively linear below a depth of about $250 \mathrm{~m}$, indicating relatively little vertical flow below this depth. The profiles are therefore consistent with ground-water flow in the southeastern part of the basin mostly occurring at depths $<250 \mathrm{~m}$.

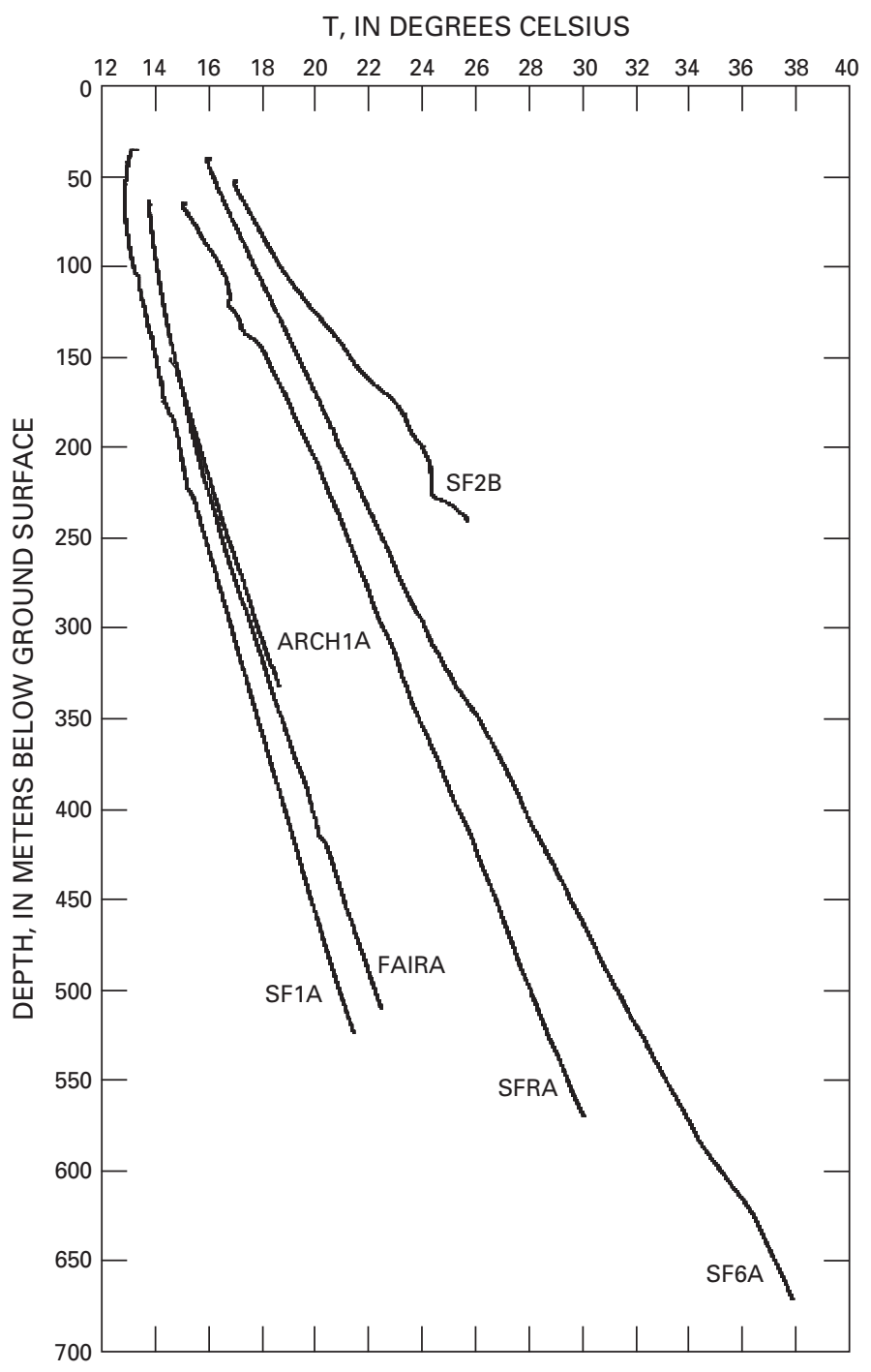

Figure 6. Temperature (T) profiles. Name of sample site where profile was measured shown next to the bottom of each profile. Location of these sample sites shown in figure 5.

\section{General Geochemistry}

The general chemical characteristics of ground water in the Española Basin are discussed in this section, along with spatial patterns in measured chemical properties and major geochemical processes that might be influencing DIC in Española Basin ground waters. Field parameters and major ion and trace element data are presented in table 3. Isotopic data $(\mathrm{H}, \mathrm{O}$, and $\mathrm{C})$ are presented in table 4.

Field parameters and major ions were compared to the ${ }^{14} \mathrm{C}$ activity of DIC to evaluate possible correlations with residence time in the saturated zone. Although factors other than age can influence the ${ }^{14} \mathrm{C}$ activity, it should still approximate reasonably well the relative age of sampled waters. If clear correlations were observed $\left(r^{2}>0.2\right)$, they are included in the following discussion. 
Table 3. Field parameters and chemical data.

[HC zone, hydrochemical zone; DO, dissolved oxygen; SC, specific conductance; TDS, total dissolved solids; $\mathrm{NO}_{2}-\mathrm{N}_{\text {and }} \mathrm{NO}^{3}-\mathrm{N}$, nitrogen as $\mathrm{NO}_{2}$ and $\mathrm{NO}_{3}$ (respectively); mS, microsiemens; eq/L, equivalents per liter; calc, calculated; W, west; NE, northeast; SE, southeast; CD, central deep; U, undetermined; LANL, Los Alamos National Lab; NMBGMR, New Mexico Bureau of Geology and Mineral Resources; field alkalinity values in italics were estimated from lab alkalinity values]

\begin{tabular}{|c|c|c|c|c|c|c|c|c|c|c|c|c|c|}
\hline \multirow[b]{2}{*}{$\begin{array}{l}\text { Sample } \\
\text { name }\end{array}$} & \multirow[b]{2}{*}{$\begin{array}{c}\text { HC } \\
\text { zone }\end{array}$} & \multicolumn{5}{|c|}{ Field parameters } & \multirow[b]{2}{*}{ Lab } & \multicolumn{6}{|c|}{ General chemistry } \\
\hline & & $\begin{array}{c}\mathrm{T} \\
\left({ }^{\circ} \mathrm{C}\right)\end{array}$ & $\begin{array}{c}\text { DO } \\
\text { (mg/L) }\end{array}$ & $\begin{array}{c}\text { SC } \\
(\mu \mathrm{S} / \mathrm{cm})\end{array}$ & $\begin{array}{c}\text { Field } \\
\text { akalinity } \\
\left(\mathrm{mg} / \mathrm{L} \mathrm{CaCO}_{3}\right)\end{array}$ & pH & & $\begin{array}{c}\text { Lab } \\
\text { alkalinity } \\
\left(\mathrm{mg} / \mathrm{CaCO}_{3}\right)\end{array}$ & $\begin{array}{l}\text { Lab } \\
\mathrm{pH}\end{array}$ & $\begin{array}{c}\text { TDS } \\
\text { (mg/L) }\end{array}$ & $\begin{array}{c}\text { Total } \\
\text { anions } \\
\text { (eq/L) }\end{array}$ & $\begin{array}{c}\text { Total } \\
\text { cations } \\
\text { (eq/L) }\end{array}$ & $\begin{array}{c}\text { Charge } \\
\text { balance } \\
(\%)\end{array}$ \\
\hline BECK'S SPRING & SE & 3.2 & 7.49 & 37 & $\mathrm{U}$ & 6.09 & LANL & 11.4 & $\mathrm{U}$ & 37 & 0.0003 & 0.0003 & 0.3 \\
\hline WMWB44-01 & SE & 13.4 & 5.35 & 799 & 287 & 7.18 & LANL & 283.6 & 7.42 & 639 & 0.0085 & 0.0084 & 1.0 \\
\hline WAS1-01 & $\mathrm{NE}$ & 25.0 & 6.50 & 367 & 156 & 9.08 & LANL & 149.9 & 9.06 & 332 & 0.0041 & 0.0034 & 10.1 \\
\hline WLAOB-01 & $\mathrm{W}$ & 11.5 & 13.10 & 211 & 87 & 6.82 & LANL & 67.9 & 7.29 & 184 & 0.0020 & 0.0020 & -1.2 \\
\hline WR2-01 & W & 24.6 & 4.80 & 148 & 80 & 7.39 & LANL & 60.5 & $\mathrm{U}$ & 210 & 0.0015 & 0.0013 & 7.3 \\
\hline WR4-01 & W & 25.4 & 3.57 & 173 & 84 & 7.95 & LANL & 65.3 & $\mathrm{U}$ & 208 & 0.0017 & 0.0015 & 7.3 \\
\hline WR18-01 & W & 17.1 & 4.60 & 110 & 72 & 7.63 & LANL & 51.6 & 7.56 & 149 & 0.0011 & 0.0011 & -1.5 \\
\hline WR23-01 & $\mathrm{W}$ & 21.9 & $\mathrm{U}$ & 172 & 89 & 7.23 & LANL & 70.2 & 8.06 & 199 & 0.0016 & 0.0017 & -1.2 \\
\hline WCHIM1-01 & $\mathrm{NE}$ & 21.8 & 1.98 & 754 & 342 & 6.90 & LANL & 348.8 & 7.54 & 720 & 0.0083 & 0.0091 & -4.7 \\
\hline WBYN-01 & $\mathrm{NE}$ & 15.4 & 3.58 & 669 & 228 & 7.77 & LANL & 207.5 & 7.80 & 601 & 0.0072 & 0.0066 & 4.7 \\
\hline WBELL-01 & $\mathrm{NE}$ & 15.6 & 4.52 & 628 & 250 & 7.13 & LANL & 236.9 & 7.31 & 525 & 0.0059 & 0.0066 & -5.5 \\
\hline WSF2B-01 & $\mathrm{CD}$ & 18.6 & $\mathrm{U}$ & 1029 & $\mathrm{U}$ & 6.81 & NMBGMR & 466 & 7.50 & 570 & 0.0096 & 0.0101 & -2.3 \\
\hline WSF2C-01 & SE & 19.3 & $\mathrm{U}$ & 417 & 176 & 7.97 & NMBGMR & 164 & 8.30 & 263 & 0.0042 & 0.0041 & 0.8 \\
\hline WSF6A-01 & $\mathrm{CD}$ & 20.7 & 0.21 & 1354 & $\mathrm{U}$ & 6.91 & NMBGMR & 708 & 7.80 & 863 & 0.0150 & 0.0154 & -1.3 \\
\hline WSF6B-01 & $\mathrm{CD}$ & 20.8 & 0.13 & 836 & $\mathrm{U}$ & 7.24 & NMBGMR & 405 & 8.10 & 516 & 0.0089 & 0.0091 & -1.2 \\
\hline WSF6C-01 & SE & 18.1 & $\mathrm{U}$ & 363 & 157 & 7.34 & NMBGMR & 143 & 8.10 & 233 & 0.0037 & 0.0035 & 2.3 \\
\hline WSFRA-01 & SE & 19.6 & 0.58 & 551 & 251 & 8.45 & NMBGMR & 245 & 8.50 & 316 & 0.0056 & 0.0052 & 4.2 \\
\hline WSFRB-01 & SE & 18.0 & 7.30 & 288 & 138 & 8.08 & NMBGMR & 123 & 8.20 & 191 & 0.0030 & 0.0030 & 0.8 \\
\hline WSFRC-01 & SE & 16.3 & $\mathrm{U}$ & 159 & 96 & 8.03 & NMBGMR & 78 & 8.00 & 108 & 0.0016 & 0.0017 & -1.2 \\
\hline WFAIRA-01 & SE & 16.8 & 3.72 & 222 & 118 & 7.69 & NMBGMR & 102 & 7.90 & 147 & 0.0023 & 0.0019 & 8.1 \\
\hline WFAIRB-01 & SE & 15.5 & $\mathrm{U}$ & 228 & 118 & 7.51 & NMBGMR & 102 & 8.00 & 151 & 0.0023 & 0.0023 & -0.3 \\
\hline WARCH1A-01 & SE & 16.3 & 6.28 & 276 & 149 & 7.45 & NMBGMR & 135 & 7.90 & 180 & 0.0029 & 0.0030 & -1.9 \\
\hline WARCH1B-01 & SE & 12.9 & $\mathrm{U}$ & 320 & 138 & 7.37 & NMBGMR & 123 & 7.90 & 210 & 0.0032 & 0.0030 & 4.0 \\
\hline WARCH1C-01 & SE & 14.2 & $\mathrm{U}$ & 396 & 157 & 7.49 & NMBGMR & 143 & 8.20 & 245 & 0.0039 & 0.0038 & 1.8 \\
\hline WCCDX1B-01 & SE & 23.1 & 6.01 & 234 & 132 & 7.60 & LANL & 122.0 & 7.79 & 231 & 0.0024 & 0.0027 & -5.0 \\
\hline WMWA-01 & SE & 13.5 & 1.31 & 486 & 192 & 7.30 & LANL & 172.5 & 7.54 & 373 & 0.0044 & 0.0049 & -5.4 \\
\hline WMWB-02 & SE & 13.7 & 5.58 & 982 & 290 & 7.11 & LANL & 295.9 & 7.22 & 782 & 0.0105 & 0.0095 & 5.3 \\
\hline WSM-03 & SE & 15.0 & 7.12 & 369 & 118 & 7.71 & LANL & 101.6 & 7.76 & 293 & 0.0037 & 0.0036 & 2.2 \\
\hline WNW-02 & SE & 19.8 & 7.95 & 220 & 116 & 7.96 & LANL & 99.2 & 7.97 & 206 & 0.0023 & 0.0022 & 2.3 \\
\hline WTOR-02 & SE & 13.8 & 7.32 & 334 & 142 & 7.44 & LANL & 125.4 & 7.67 & 272 & 0.0033 & 0.0029 & 7.3 \\
\hline WAF-01 & SE & 13.7 & 4.44 & 281 & 140 & 7.37 & LANL & 120.5 & 7.58 & 251 & 0.0026 & 0.0028 & -4.1 \\
\hline WSFO3-01 & SE & 18.0 & 2.76 & 326 & 169 & 7.43 & LANL & 154.9 & 7.68 & 306 & 0.0031 & 0.0036 & -7.7 \\
\hline WHURL-01 & SE & 16.0 & 6.45 & 256 & 120 & 7.57 & LANL & 110.7 & 7.83 & 221 & 0.0026 & 0.0025 & 3.0 \\
\hline WHOTCH-01 & SE & 15.3 & 0.14 & 572 & 240 & 7.73 & LANL & 221.3 & 7.80 & 505 & 0.0061 & 0.0061 & 0.7 \\
\hline WLEYB-01 & SE & 20.9 & 6.70 & 284 & 140 & 7.87 & LANL & 126.2 & 8.03 & 261 & 0.0027 & 0.0030 & -5.6 \\
\hline WGON-01 & SE & 17.0 & 4.04 & 286 & 135 & 8.06 & LANL & 118.4 & 7.95 & 252 & 0.0026 & 0.0029 & -5.3 \\
\hline
\end{tabular}


Table 3. Field parameters and chemical data.-Continued

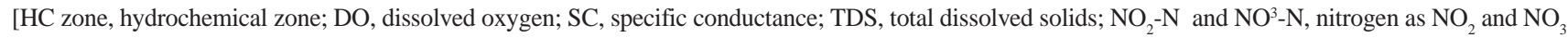
(respectively); mS, microsiemens; eq/L, equivalents per liter; calc, calculated; W, west; NE, northeast; SE, southeast; CD, central deep; U, undetermined; LANL, Los Alamos National Lab; NMBGMR, New Mexico Bureau of Geology and Mineral Resources; field alkalinity values in italics were estimated from lab alkalinity values]

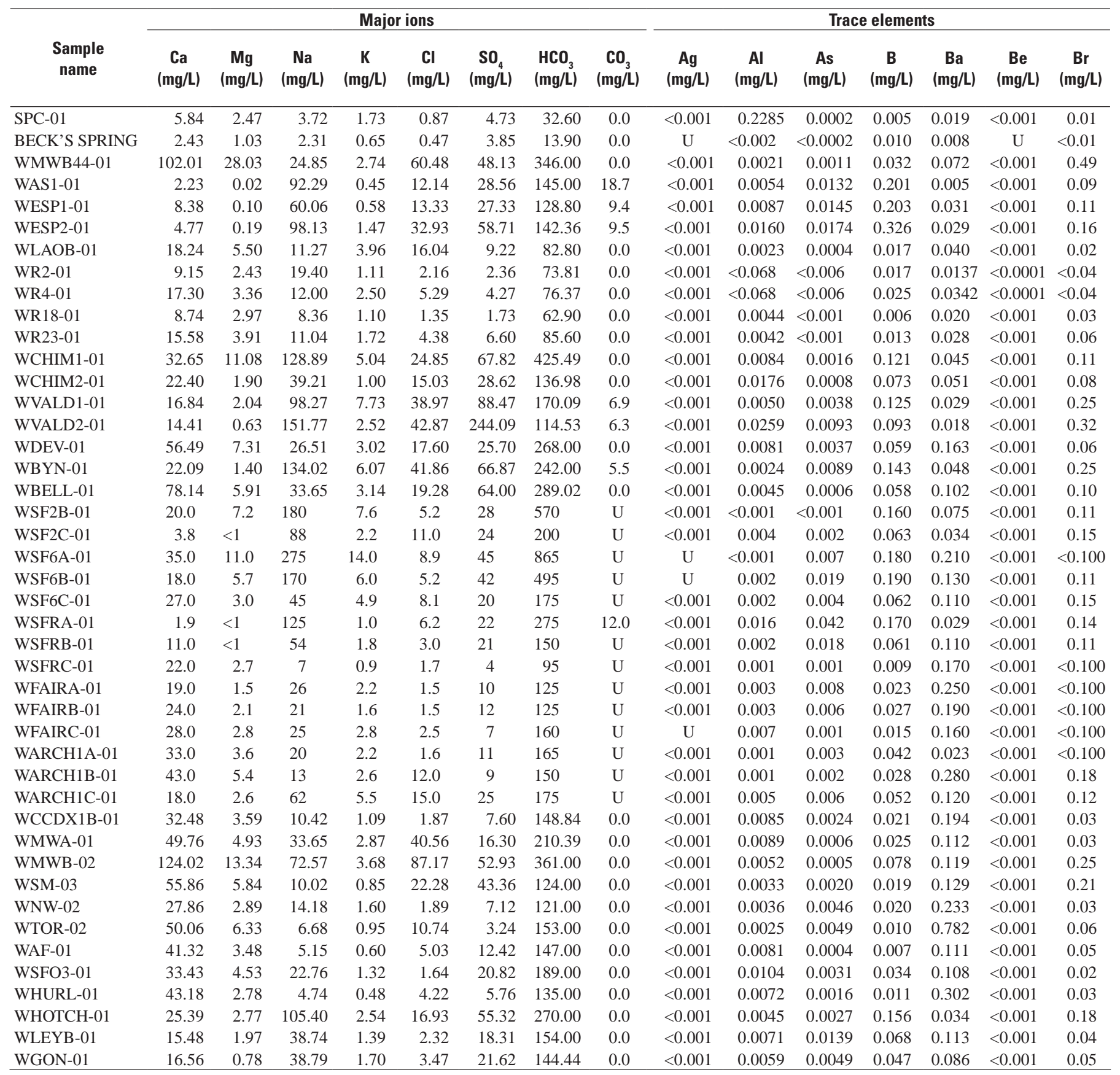


Table 3. Field parameters and chemical data._-Continued

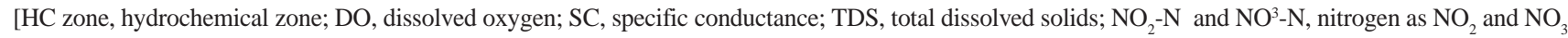
(respectively); mS, microsiemens; eq/L, equivalents per liter; calc, calculated; W, west; NE, northeast; SE, southeast; CD, central deep; U, undetermined; LANL, Los Alamos National Lab; NMBGMR, New Mexico Bureau of Geology and Mineral Resources; field alkalinity values in italics were estimated from lab alkalinity values]

\begin{tabular}{|c|c|c|c|c|c|c|c|c|c|c|c|c|c|c|}
\hline \multirow[b]{2}{*}{$\begin{array}{c}\text { Sample } \\
\text { name }\end{array}$} & \multicolumn{14}{|c|}{ Trace elements } \\
\hline & $\begin{array}{c}\text { Cd } \\
\text { (mg/L) }\end{array}$ & $\begin{array}{c}\text { Co } \\
\text { (mg/L) }\end{array}$ & $\begin{array}{c}\mathrm{Cr} \\
(\mathrm{mg} / \mathrm{L})\end{array}$ & $\begin{array}{c}\text { Cs } \\
\text { (mg/L) }\end{array}$ & $\underset{(\mathrm{mg} / \mathrm{L})}{\mathrm{Cu}}$ & $\underset{(m g / L)}{F}$ & $\begin{array}{c}\mathrm{Fe} \\
(\mathrm{mg} / \mathrm{L})\end{array}$ & $\underset{(\mathrm{mg} / \mathrm{L})}{\mathrm{Hg}}$ & $\underset{(\mathrm{mg} / \mathrm{L})}{\mathrm{Li}}$ & $\underset{(\mathrm{mg} / \mathrm{L})}{\mathrm{Mn}}$ & $\underset{(\mathrm{mg} / \mathrm{L})}{\mathrm{Mo}}$ & $\underset{(\mathrm{mg} / \mathrm{L})}{\mathrm{Ni}}$ & $\begin{array}{c}\mathrm{NO}_{2} \\
(\mathrm{mg} / \mathrm{L})\end{array}$ & $\begin{array}{c}\mathrm{NO}_{3} \\
\text { (mg/L) }\end{array}$ \\
\hline BECK'S SPRING & $\mathrm{U}$ & U & $<0.001$ & $\mathrm{U}$ & U & 0.04 & $<0.01$ & U & 0.002 & $\mathrm{U}$ & $\mathrm{U}$ & $\mathrm{U}$ & $\mathrm{U}$ & 0.27 \\
\hline WMWB44-01 & $<0.001$ & $<0.001$ & 0.0028 & 0.003 & 0.0020 & 0.44 & $<0.01$ & $<0.00005$ & 0.032 & 0.0010 & $<0.001$ & $<0.001$ & $<0.01$ & 9.41 \\
\hline WAS1-01 & $<0.001$ & $<0.001$ & 0.0056 & $<0.001$ & 0.0019 & 0.63 & $<0.01$ & 0.00007 & 0.132 & $<0.001$ & 0.0016 & $<0.001$ & $<0.01$ & 3.68 \\
\hline WLAOB-01 & $<0.001$ & $<0.001$ & $<0.001$ & $<0.001$ & $<0.001$ & 0.08 & $<0.01$ & $<0.00005$ & 0.005 & $<0.001$ & $<0.001$ & $<0.001$ & $<0.01$ & 0.46 \\
\hline WR2-01 & $<0.0001$ & $<0.001$ & 0.0037 & $<0.001$ & $<0.003$ & 0.20 & $<0.018$ & $<0.00005$ & 0.025 & 0.0229 & 0.0027 & 0.0027 & U & $\mathrm{U}$ \\
\hline WR4-01 & $<0.0001$ & $<0.001$ & 0.0045 & $<0.001$ & $<0.003$ & 0.55 & $<0.018$ & $<0.00005$ & 0.026 & $<0.001$ & 0.0022 & 0.0041 & $\mathrm{U}$ & $\mathrm{U}$ \\
\hline WR18-01 & $<0.001$ & $<0.001$ & 0.0014 & $<0.001$ & 0.0013 & 0.06 & $<0.01$ & $<0.00005$ & 0.014 & $<0.001$ & $<0.001$ & $<0.001$ & $<0.01$ & 2.37 \\
\hline WR23-01 & $<0.001$ & $<0.001$ & 0.0023 & $<0.001$ & $<0.001$ & 0.40 & $<0.01$ & $<0.00005$ & 0.023 & 0.0028 & 0.0017 & $<0.001$ & $<0.01$ & 5.71 \\
\hline WCHIM1-01 & $<0.001$ & $<0.001$ & 0.0019 & $<0.001$ & 0.0025 & 4.09 & 1.16 & $<0.00005$ & 0.167 & 0.1016 & 0.0238 & 0.0019 & $<0.01$ & 0.04 \\
\hline WBYN-01 & $<0.001$ & $<0.001$ & 0.0033 & $<0.001$ & 0.0034 & 0.68 & $<0.01$ & $<0.00005$ & 0.122 & $<0.001$ & 0.0025 & $<0.001$ & $<0.01$ & 14.76 \\
\hline WBELL-01 & $<0.001$ & $<0.001$ & 0.0020 & $<0.001$ & 0.0042 & 0.33 & $<0.01$ & $<0.00005$ & 0.046 & $<0.001$ & $<0.001$ & 0.0025 & $<0.01$ & 6.28 \\
\hline WSF2B-01 & $<0.001$ & $<0.001$ & $<0.001$ & $\mathrm{U}$ & 0.006 & 0.14 & 0.23 & U & 0.200 & 0.220 & 0.002 & 0.002 & $<0.100$ & 3.7 \\
\hline WSF2C-01 & $<0.001$ & $<0.001$ & $<0.001$ & $\mathrm{U}$ & 0.004 & 0.21 & 0.05 & $\mathrm{U}$ & 0.070 & 0.031 & $<0.001$ & $<0.001$ & $<0.100$ & 8.5 \\
\hline WSF6A-01 & $<0.001$ & $<0.001$ & 0.0010 & $\mathrm{U}$ & 0.008 & 0.72 & 0.25 & $\mathrm{U}$ & 0.240 & 0.063 & 0.013 & 0.002 & $<0.100$ & $<0.100$ \\
\hline WSF6B-01 & $<0.001$ & $<0.001$ & 0.0010 & $\mathrm{U}$ & 0.005 & 0.79 & 0.08 & $\mathrm{U}$ & 0.190 & 0.029 & 0.018 & 0.012 & $<0.100$ & $<0.100$ \\
\hline WSF6C-01 & $<0.001$ & $<0.001$ & $<0.001$ & $\mathrm{U}$ & 0.002 & 0.29 & 0.12 & $\mathrm{U}$ & 0.026 & 0.024 & 0.005 & 0.001 & $<0.100$ & 12.0 \\
\hline WSFRA-01 & $<0.001$ & $<0.001$ & 0.0060 & $\mathrm{U}$ & 0.005 & 1.60 & 0.02 & $\mathrm{U}$ & 0.069 & 0.009 & 0.002 & $<0.001$ & $<0.100$ & 1.3 \\
\hline WSFRB-01 & $<0.001$ & $<0.001$ & 0.0050 & $\mathrm{U}$ & 0.003 & 0.40 & 0.04 & $\mathrm{U}$ & 0.030 & 0.002 & 0.002 & $<0.001$ & $<0.100$ & 3.8 \\
\hline WSFRC-01 & $<0.001$ & $<0.001$ & $<0.001$ & $\mathrm{U}$ & 0.001 & 0.29 & 0.10 & $\mathrm{U}$ & 0.004 & $<0.001$ & $<0.001$ & $<0.001$ & $<0.100$ & 1.4 \\
\hline WFAIRA-01 & $<0.001$ & $<0.001$ & $<0.001$ & U & 0.001 & 0.27 & 0.09 & $\mathrm{U}$ & 0.016 & 0.090 & 0.011 & 0.001 & $<0.100$ & 0.4 \\
\hline WFAIRB-01 & $<0.001$ & $<0.001$ & 0.0010 & $\mathrm{U}$ & 0.001 & 0.28 & 0.10 & $\mathrm{U}$ & 0.014 & 0.002 & 0.002 & $<0.001$ & $<0.100$ & 1.1 \\
\hline WNW-02 & $<0.001$ & $<0.001$ & $<0.001$ & $<0.001$ & 0.0077 & 0.30 & $<0.01$ & $<0.00005$ & 0.009 & $<0.001$ & 0.0017 & $<0.001$ & $<0.01$ & 3.29 \\
\hline WTOR-02 & $<0.001$ & $<0.001$ & $<0.001$ & $<0.001$ & 0.0028 & 0.13 & $<0.01$ & $<0.00005$ & 0.006 & $<0.001$ & $<0.001$ & $<0.001$ & $<0.01$ & 22.00 \\
\hline WAF-01 & $<0.001$ & $<0.001$ & $<0.001$ & $<0.001$ & 0.0022 & 0.17 & $<0.01$ & $<0.00005$ & 0.003 & $<0.001$ & $<0.001$ & 0.0011 & $<0.01$ & 9.74 \\
\hline WSFO3-01 & $<0.001$ & $<0.001$ & 0.0010 & $<0.001$ & 0.0062 & 0.23 & 0.01 & $<0.00005$ & 0.018 & $<0.001$ & 0.0011 & 0.0015 & $<0.01$ & 1.33 \\
\hline WHURL-01 & $<0.001$ & $<0.001$ & $<0.001$ & $<0.001$ & 0.0019 & 0.16 & $<0.01$ & $<0.00005$ & 0.004 & $<0.001$ & $<0.001$ & $<0.001$ & $<0.01$ & 7.83 \\
\hline WHOTCH-01 & $<0.001$ & $<0.001$ & 0.0011 & $<0.001$ & 0.0030 & 0.14 & 0.03 & $<0.00005$ & 0.097 & 0.0094 & 0.0018 & 0.0010 & $<0.01$ & 9.07 \\
\hline WLEYB-01 & $<0.001$ & $<0.001$ & 0.0020 & $<0.001$ & 0.0033 & 0.63 & $<0.01$ & $<0.00005$ & 0.032 & $<0.001$ & 0.0027 & $<0.001$ & $<0.01$ & 5.39 \\
\hline WGON-01 & $<0.001$ & $<0.001$ & 0.0015 & $<0.001$ & 0.0025 & 0.44 & 0.02 & $<0.00005$ & 0.043 & $<0.001$ & 0.0030 & $<0.001$ & $<0.01$ & 4.05 \\
\hline
\end{tabular}


Table 3. Field parameters and chemical data.-Continued

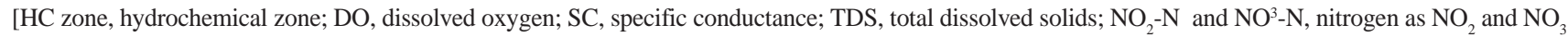
(respectively); mS, microsiemens; eq/L, equivalents per liter; calc, calculated; W, west; NE, northeast; SE, southeast; CD, central deep; U, undetermined; LANL, Los Alamos National Lab; NMBGMR, New Mexico Bureau of Geology and Mineral Resources; field alkalinity values in italics were estimated from lab alkalinity values]

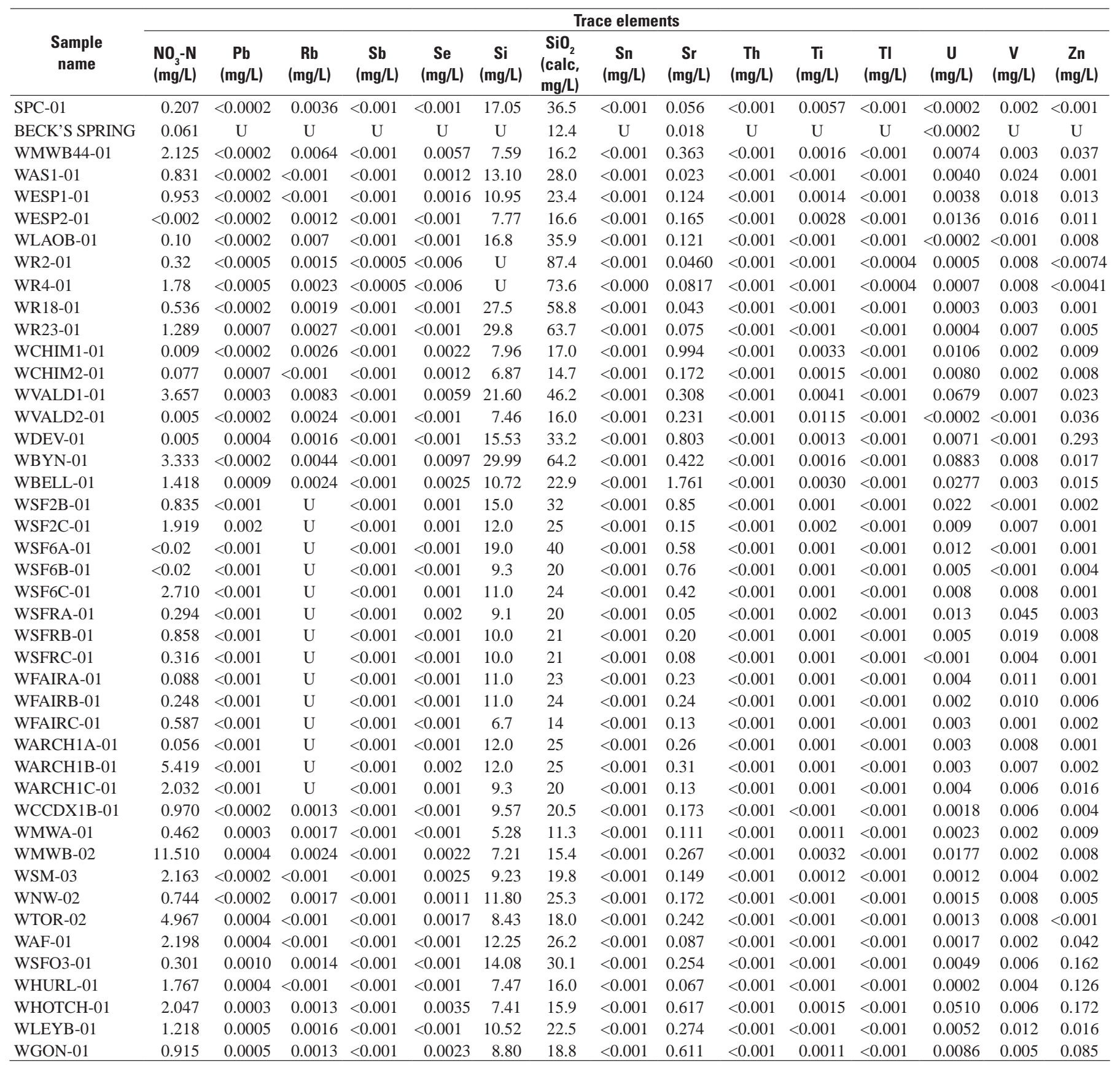


Table 4. Hydrogen and oxygen isotopic data for water, and carbon isotopic data for dissolved inorganic carbon.

[pmC, percent modern carbon; $\mathrm{U}$, undetermined; sample names ending with $\mathrm{R}$ are replicates of the sample immediately above]

\begin{tabular}{|c|c|c|c|c|c|}
\hline $\begin{array}{c}\text { Sample } \\
\text { name }\end{array}$ & $\begin{array}{c}\delta^{2} \mathrm{H} \\
\text { (per mil) }\end{array}$ & $\begin{array}{c}\delta^{180} 0 \\
\text { (per mil }\end{array}$ & $\begin{array}{c}\delta^{13} \mathbf{C} \\
\text { (per mil) }\end{array}$ & $\begin{array}{l}{ }^{14} \mathrm{C} \\
\text { activity } \\
\text { (pmC) }\end{array}$ & $\begin{array}{l}1 \sigma^{14} \mathrm{C} \\
\text { error } \\
(\mathrm{pmC})\end{array}$ \\
\hline SPC-01 & & & -14.70 & 110.53 & 0.47 \\
\hline BECK'S SPRING & -90.42 & -13.43 & -19.10 & 104.34 & 0.43 \\
\hline WMWB44-01 & $\mathrm{U}$ & $\mathrm{U}$ & -13.30 & 97.60 & 0.50 \\
\hline WAS1-01 & $\mathrm{U}$ & $\mathrm{U}$ & -9.89 & 3.13 & 0.10 \\
\hline WAS1-01R & $\mathrm{U}$ & $\mathrm{U}$ & -9.95 & 3.33 & 0.11 \\
\hline WESP1-01 & $\mathrm{U}$ & $\mathrm{U}$ & -9.76 & 9.82 & 0.15 \\
\hline WESP2-01 & $\mathrm{U}$ & $\mathrm{U}$ & -9.14 & 4.92 & 0.14 \\
\hline WLAOB-01 & -80.08 & -11.84 & -15.82 & 107.90 & 0.50 \\
\hline WR2-01 & -74.76 & -10.84 & -14.30 & 58.17 & 0.31 \\
\hline WR4-01 & -72.31 & -10.54 & -11.10 & 37.75 & 0.21 \\
\hline WR18-01 & -84.39 & -11.95 & -14.20 & 91.27 & 0.41 \\
\hline WR23-01 & -77.05 & -10.71 & -9.90 & 60.86 & 0.33 \\
\hline WCHIM1-01 & $\mathrm{U}$ & $\mathrm{U}$ & -6.17 & 25.96 & 0.23 \\
\hline WCHIM2-01 & $\mathrm{U}$ & $\mathrm{U}$ & -14.42 & 82.46 & 0.41 \\
\hline WVALD1-01 & $\mathrm{U}$ & $\mathrm{U}$ & -8.33 & 12.17 & 0.15 \\
\hline WVALD2-01 & $\mathrm{U}$ & $\mathrm{U}$ & -9.82 & 2.71 & 0.12 \\
\hline WDEV-01 & $\mathrm{U}$ & $\mathrm{U}$ & -10.90 & 91.94 & 0.45 \\
\hline WBYN-01 & $\mathrm{U}$ & $\mathrm{U}$ & -11.20 & 51.09 & 0.50 \\
\hline WBELL-01 & $\mathrm{U}$ & $\mathrm{U}$ & -11.22 & 94.44 & 0.44 \\
\hline WSF2B-01 & -116.59 & -15.78 & -2.81 & 0.73 & 0.11 \\
\hline WSF2C-01 & -92.38 & -12.78 & -7.73 & 36.63 & 0.23 \\
\hline WSF6A-01 & -104.20 & -14.71 & -3.46 & 0.86 & 0.10 \\
\hline WSF6B-01 & -110.08 & -15.02 & -5.31 & 1.30 & 0.11 \\
\hline WSF6C-01 & -84.65 & -12.02 & -7.38 & 30.90 & 0.22 \\
\hline WSFRA-01 & -103.58 & -14.27 & -5.53 & 1.27 & 0.11 \\
\hline WSFRB-01 & -113.33 & -15.65 & -8.16 & 1.04 & 0.11 \\
\hline WSFRC-01 & -83.23 & -12.34 & -11.60 & 56.00 & 0.31 \\
\hline WFAIRA-01 & -80.30 & -12.09 & -10.96 & 12.89 & 0.18 \\
\hline WFAIRB-01 & -77.89 & -11.71 & -9.74 & 7.59 & 0.14 \\
\hline WFAIRC-01 & -82.44 & -12.26 & -12.30 & 65.27 & 0.45 \\
\hline WARCH1A-01 & -79.22 & -12.06 & -9.92 & 35.66 & 0.23 \\
\hline WARCH1B-01 & -83.35 & -12.37 & -9.19 & 40.80 & 0.25 \\
\hline WARCH1C-01 & -84.77 & -12.40 & -10.00 & 46.26 & 0.29 \\
\hline WCCDX1B-01 & $\mathrm{U}$ & U & -9.60 & 47.32 & 0.29 \\
\hline WMWA-01 & $\mathrm{U}$ & $\mathrm{U}$ & -13.76 & 75.91 & 0.38 \\
\hline WMWB-02 & $\mathrm{U}$ & $\mathrm{U}$ & -14.10 & 66.73 & 0.40 \\
\hline WSM-03 & $\mathrm{U}$ & $\mathrm{U}$ & -11.50 & 61.59 & 0.40 \\
\hline WNW-02 & $\mathrm{U}$ & $\mathrm{U}$ & -10.30 & 38.60 & 0.30 \\
\hline WTOR-02 & $\mathrm{U}$ & $\mathrm{U}$ & -11.10 & 77.40 & 0.40 \\
\hline WAF-01 & $\mathrm{U}$ & $\mathrm{U}$ & -10.55 & 84.52 & 0.37 \\
\hline WAF-01R & $\mathrm{U}$ & $\mathrm{U}$ & -10.48 & 83.60 & 0.42 \\
\hline WSFO3-01 & $\mathrm{U}$ & $\mathrm{U}$ & -10.10 & 8.80 & 0.20 \\
\hline WHURL-01 & $\mathrm{U}$ & $\mathrm{U}$ & -10.50 & 80.09 & 0.37 \\
\hline WHOTCH-01 & $\mathrm{U}$ & -13.83 & -12.30 & 13.11 & 0.20 \\
\hline WLEYB-01 & $\mathrm{U}$ & $\mathrm{U}$ & -8.87 & 8.07 & 0.14 \\
\hline WGON-01 & $\mathrm{U}$ & $\mathrm{U}$ & -8.51 & 2.05 & 0.11 \\
\hline
\end{tabular}

\section{Chemical and Isotopic Composition of Ground Water}

\section{Field Parameters}

Dissolved oxygen (DO) concentrations range from 0.13 to $9.33 \mathrm{mg} / \mathrm{L}$, with a mean of $4.17 \mathrm{mg} / \mathrm{L}$. DO measurements are unavailable for some of the piezometers due to malfunction of the field probe during sampling in April 2005. Ground water in the study area is generally oxygenated; only five samples have DO levels $<0.5 \mathrm{mg} / \mathrm{L}$. DO concentrations in the northeastern part of the basin (from the vicinity of the Pojoaque River northward) are generally lower than the rest of the basin (fig. 7). DO concentrations do not display well-defined variations with depth, though deeper samples are more likely to have lower DO concentrations.

Specific conductance ranges from 37 to $1,354 \mu \mathrm{S} / \mathrm{cm}$, with a mean of $425 \mu \mathrm{S} / \mathrm{cm}$. Specific conductance is highly correlated with the laboratory-measured total dissolved solids concentration $\left(r^{2}=0.90\right)$, as expected, so both parameters have essentially the same spatial distribution. Specific conductance is generally the lowest on the Pajarito Plateau (vicinity of Los Alamos), and generally the highest in the northeastern part of the basin (fig. 8). Intermediate values are generally observed in the southeastern part of the basin (vicinity of Santa Fe) (fig. 8). In the southeastern part of the basin, specific conductance decreases slightly with depth in piezometer nests closer to the mountain front (FAIR and ARCH1), and increases with depth in piezometer nests farther from the mountain front (SF2, SF6, and SFR) (fig. 9).

Field $\mathrm{pH}$ values range from 6.09 to 9.08 , with a mean of 7.55 , indicating that ground water in most of the basin is slightly alkaline. Temperatures range from $3.2^{\circ} \mathrm{C}$ to $25.4^{\circ} \mathrm{C}$, with a mean of $16.9^{\circ} \mathrm{C}$. Horizontal temperature and $\mathrm{pH}$ distributions do not display any broad, well-defined trends (figs. 10 and 11). However, higher temperatures and $\mathrm{pH}$ values are more commonly found farther from the mountain fronts and farther from the rivers traversing the east side of the basin. Because these are probable recharge areas, this pattern suggests that both temperature and $\mathrm{pH}$ generally increase with residence time in the saturated zone (as expected for temperature). A positive correlation between $\mathrm{pH}$ and ${ }^{14} \mathrm{C}$ activity $\left(\mathrm{r}^{2}=0.34\right.$, fig. 12$)$ and between temperature and ${ }^{14} \mathrm{C}$ activity $\left(r^{2}=0.35\right.$, fig. 13$)$ further supports this relationship. Note that temperatures measured while sampling can be substantially different from in situ aquifer temperatures due to multiple factors. It is therefore likely that the correlation between age and in situ aquifer temperature is stronger than indicated by figure 13 .

\section{Major lons}

The charge imbalance (in percent) was computed using the equation:

where

$$
\text { charge imbalance }=\frac{100 \times(\text { cations }- \text { anions })}{(\text { cations }+ \text { anions })}
$$

cations is the sum of the cations in milliequivalents per liter and

anions is the sum of the anions in milliequivalents per liter. 


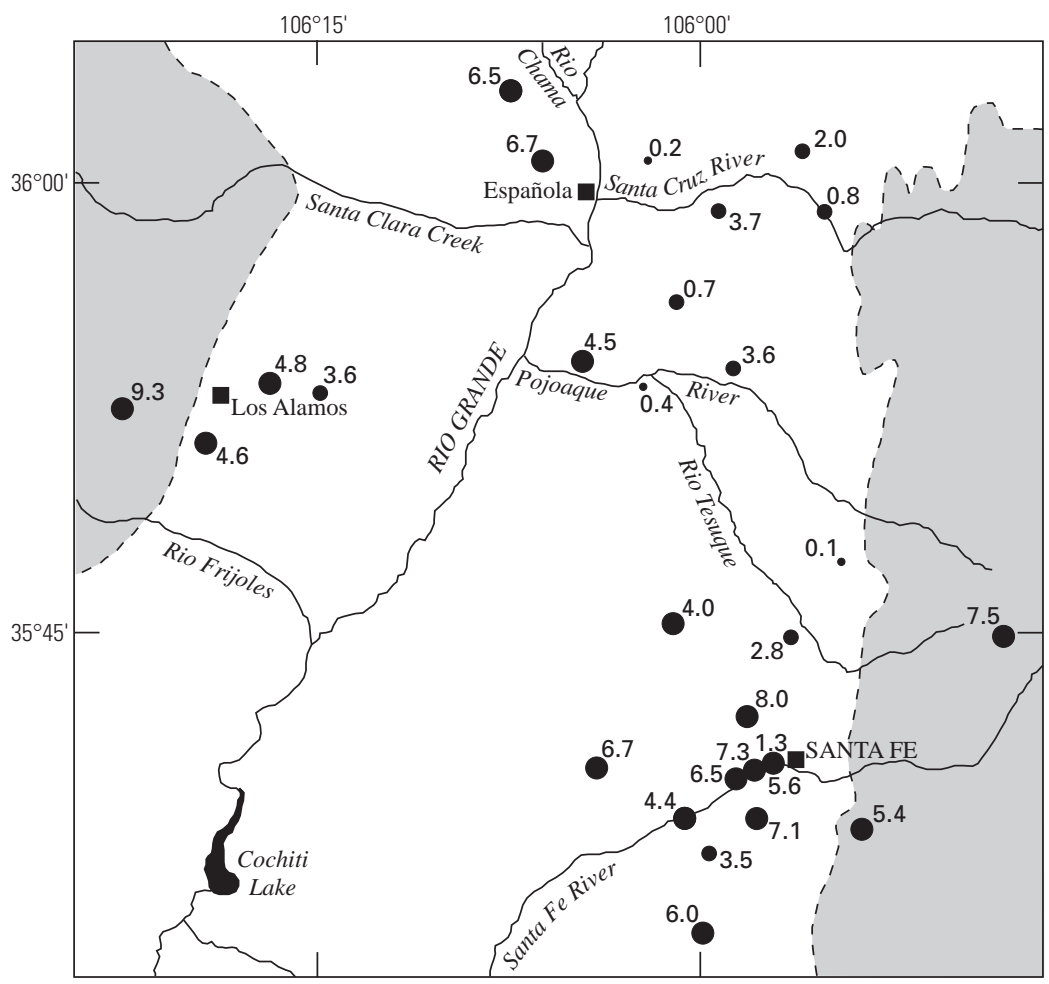

EXPLANATION

Dissolved oxygen concentration,

in milligrams per liter

$>4$

- $0.5-4$

- $<0.5$

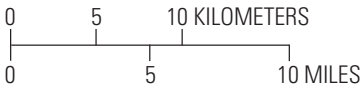

Figure 7. Lateral distribution of dissolved oxygen concentration. Shaded area is the mountain block; dashed line is the mountain front.

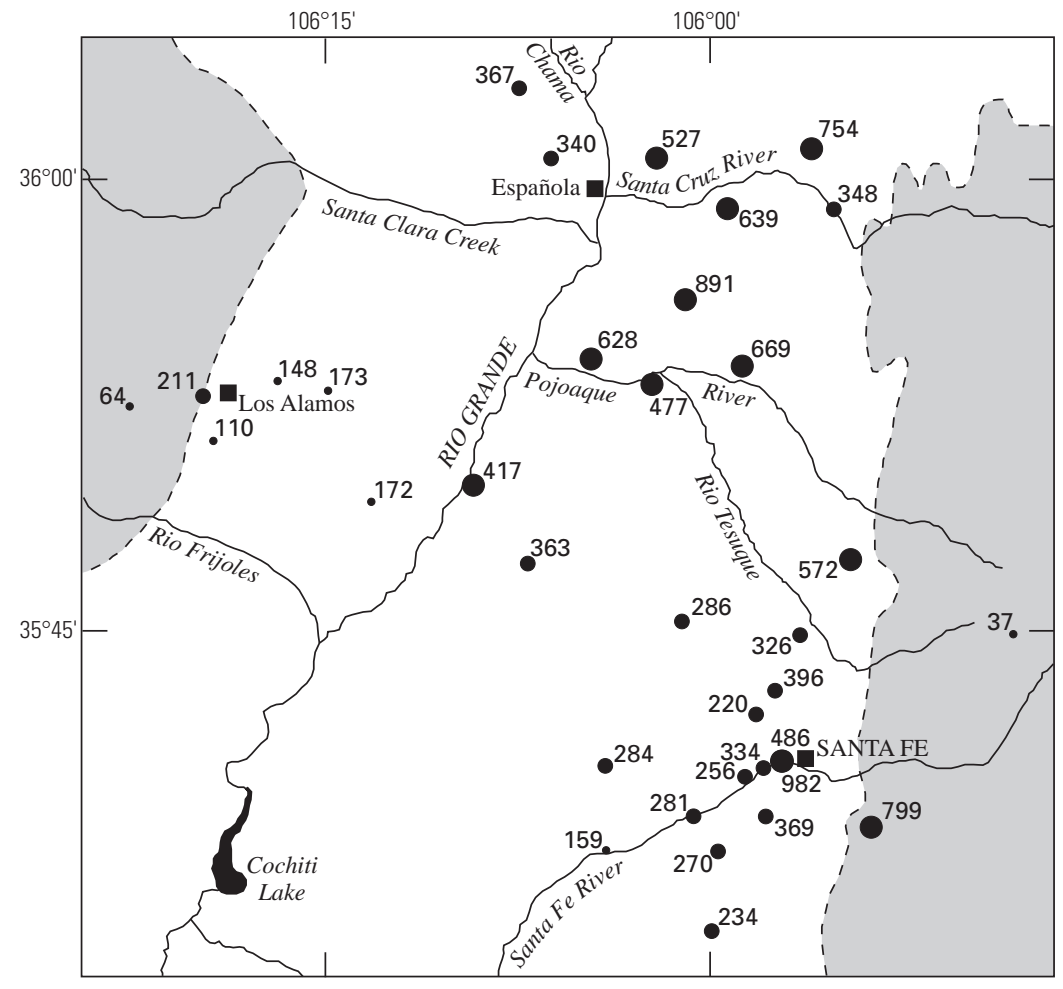

EXPLANATION

Field specific conductance, in microsiemens per centimeter

- $>400$

- 200-400

- $<200$

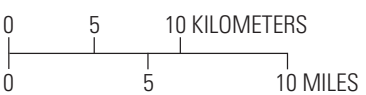

Figure 8. Lateral distribution of specific conductance. Shaded area is the mountain block; dashed line is the mountain front. 


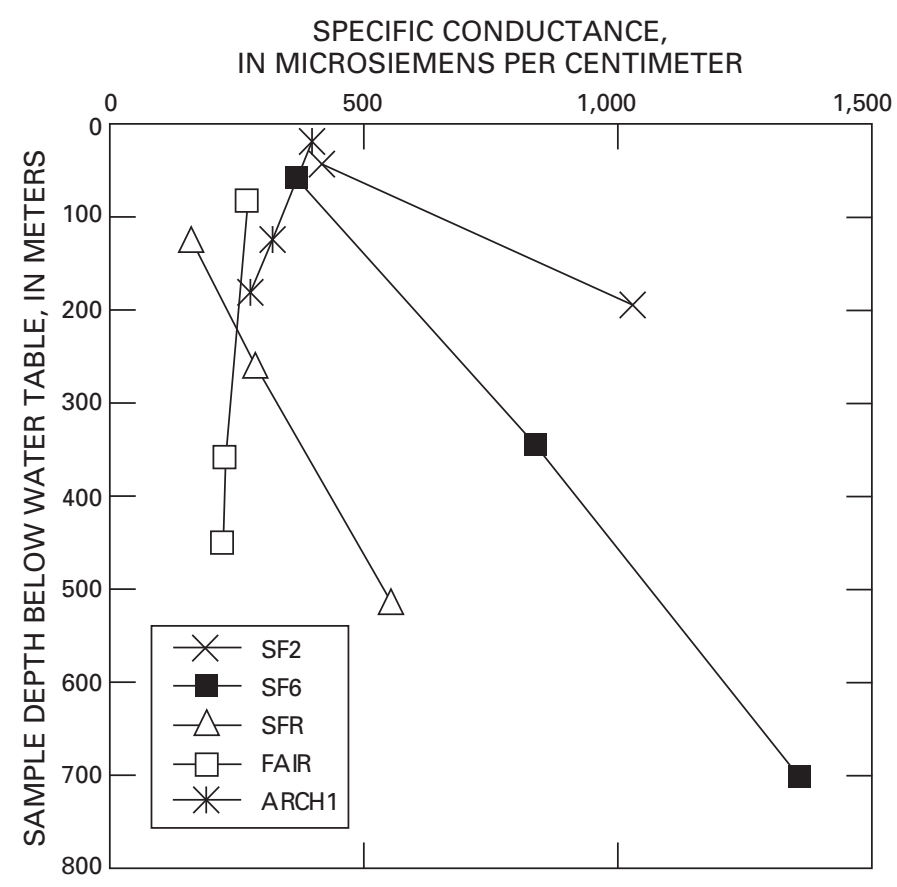

Figure 9. Vertical distribution of specific conductance in nested piezometers.

The charge imbalance reflects how well the major anions and cations balance and usually is an independent measure of the accuracy of the analytical techniques. The charge balance is acceptably low (absolute value $\leq 10$ percent) for all samples (table 3).

Samples were plotted on a Piper diagram (fig. 14) to determine the relative proportions of different major ions and to identify water types. The two dominant water types are $\mathrm{Ca} / \mathrm{CO}_{3}+\mathrm{HCO}_{3}$ and $\mathrm{Na} / \mathrm{CO}_{3}+\mathrm{HCO}_{3}$, followed by mixed-cation/ $\mathrm{CO}_{3}+\mathrm{HCO}_{3} . \mathrm{Ca}$ and $\mathrm{Na}$ are the dominant cations in sampled waters ( $\mathrm{K}$ concentrations are far lower than Na concentrations), and $\mathrm{HCO}_{3}$ is the dominant anion $\left(\mathrm{CO}_{3}\right.$ concentrations are far lower than $\mathrm{HCO}_{3}$ concentrations). Only two samples were of a different water type, $\mathrm{Na}+\mathrm{K} /$ mixed-anion and $\mathrm{Na}+\mathrm{K} / \mathrm{SO}_{4}$. Samples from the southeastern part of the basin are dominantly $\mathrm{Ca} / \mathrm{CO}_{3}+\mathrm{HCO}_{3}$ type, samples from the Pajarito Plateau are dominantly mixed-cation $/ \mathrm{CO}_{3}+\mathrm{HCO}_{3}$ type, and samples from the northeastern part of the basin are dominantly $\mathrm{Na} / \mathrm{CO}_{3}+\mathrm{HCO}_{3}$ type (fig. 15). This is consistent with findings in previous studies performed in the Chimayo area (Cumming, 1997), the Pajarito Plateau area (for example, Blake and others, 1995), and the Santa Fe area (Spiegel and Baldwin, 1963; Longmire, 1985). Plummer and others (2004a) found the same dominant water types in ground waters in the Santa Fe Group in the Middle Rio Grande Basin (MRGB), the next major basin to the south of the study area (fig. 1).

Chloride concentrations range from 0.47 to $87.17 \mathrm{mg} / \mathrm{L}$, with a mean of $14.35 \mathrm{mg} / \mathrm{L}$. Sulfate concentrations range from 1.73 to $244.09 \mathrm{mg} / \mathrm{L}$, with a mean of $30.12 \mathrm{mg} / \mathrm{L}$. Chloride and sulfate concentrations have similar spatial distributions (figs. 16 and 17). Both are generally highest in the northeastern part of the basin, lowest on the Pajarito Plateau, and most variable in the southeastern part of the basin. In the southeast, samples with the highest $\mathrm{Cl}$ and $\mathrm{SO}_{4}$ concentrations occur near Santa Fe. The nested piezometer samples show a general trend of decreasing $\mathrm{Cl}$ concentration with depth above $200 \mathrm{~m}$, then increasing concentration with depth below $200 \mathrm{~m}$ (fig. 18). $\mathrm{SO}_{4}$ concentrations generally increase with depth, but samples from ARCH1 suggest that they may locally decrease with depth in the uppermost $50 \mathrm{~m}$ of the aquifer (fig. 19). Neither $\mathrm{Cl}$ nor $\mathrm{SO}_{4}$ concentrations are well correlated with the ${ }^{14} \mathrm{C}$ activity.

Chloride typically is a conservative constituent in ground water, controlled mostly by evapotranspiration (ET). In oxygenated ground water, like that observed throughout most of the Española Basin (fig. 7), $\mathrm{SO}_{4}$ commonly is also conservative with concentrations reflecting ET. Neither $\mathrm{Cl}$ nor $\mathrm{SO}_{4}$ are conservative in aquifers containing evaporite minerals (halite and gypsum). The Tesuque Formation has a continental depositional origin, and it contains minor ( $<6$ percent) sedimentary lithic grains (Cavazza, 1986; Koning and others, 2004). It therefore probably contains few evaporites. The granitic and metamorphic rocks of the Sangre de Cristo Mountains on the east side of the basin and the volcanic and volcaniclastic rocks of the Pajarito Plateau and Jemez Mountains on the west side of the basin should contain negligible evaporite minerals. Anderholm (1994) assumed an absence of evaporite minerals in the Sangre de Cristo Mountains and the Tesuque Formation in the southeastern part of the basin in his application of $\mathrm{Cl}$ concentrations to estimate mountain-front recharge rates. $\mathrm{Cl}$ concentration is plotted versus $\mathrm{SO}_{4}$ concentration in figure 20 , and the ET trend line for bulk atmospheric deposition collected at the Sevilleta National Wildlife Refuge at the southern end of the MRGB (Plummer and others, 2004a) is also shown for comparison. About half of the samples plot near the ET trend line, consistent with $\mathrm{Cl}$ and $\mathrm{SO}_{4}$ concentrations controlled mostly by ET. However, the other half of the samples plot well to the right of the ET trend line, meaning they are either enriched in $\mathrm{Cl}$ relative to $\mathrm{SO}_{4}$ or depleted in $\mathrm{SO}_{4}$ relative to $\mathrm{Cl}$ for waters having undergone evaporation alone. It is unlikely that $\mathrm{SO}_{4}$ is depleted relative to $\mathrm{Cl}$ in many of these samples, because $\mathrm{SO}_{4}$ reduction (breakdown of $\mathrm{SO}_{4}$ by anaerobic bacteria) occurs under anoxic conditions, and few have DO concentrations $<0.5 \mathrm{mg} / \mathrm{L}$. Furthermore, invoking $\mathrm{SO}_{4}$ reduction requires that several of these samples have ET factors of 100 or greater, which seems unlikely.

Samples plotting to the right of the ET trend line in figure 20 therefore are probably enriched in $\mathrm{Cl}$. Two likely causes of $\mathrm{Cl}$ enrichment include mixing with ground water impacted by human activities and mixing with a brine from depth. Sewage discharge, septic effluent, and road salt are potential anthropogenic sources of $\mathrm{Cl}$. Ground water containing elevated $\mathrm{Cl}$ concentrations from these sources is also likely to have ${ }^{3} \mathrm{H}$ concentrations characteristic of water that is largely $<50 \mathrm{yr}$ old and/or $\mathrm{NO}_{3}$ concentrations above background levels. Table 5 lists 14 samples apparently impacted by anthropogenic sources because they meet at least two of the three following criteria: (1) Cl concentration >10 mg/L (Anderholm, 1994); (2) $\mathrm{NO}_{3}$ (as N) concentration > $2 \mathrm{mg} / \mathrm{L}$ (Mueller and Helsel, 1996); (3) ${ }^{3} \mathrm{H}$ concentration $>1 \mathrm{TU}$, indicating a nontrivial fraction of the sampled water 

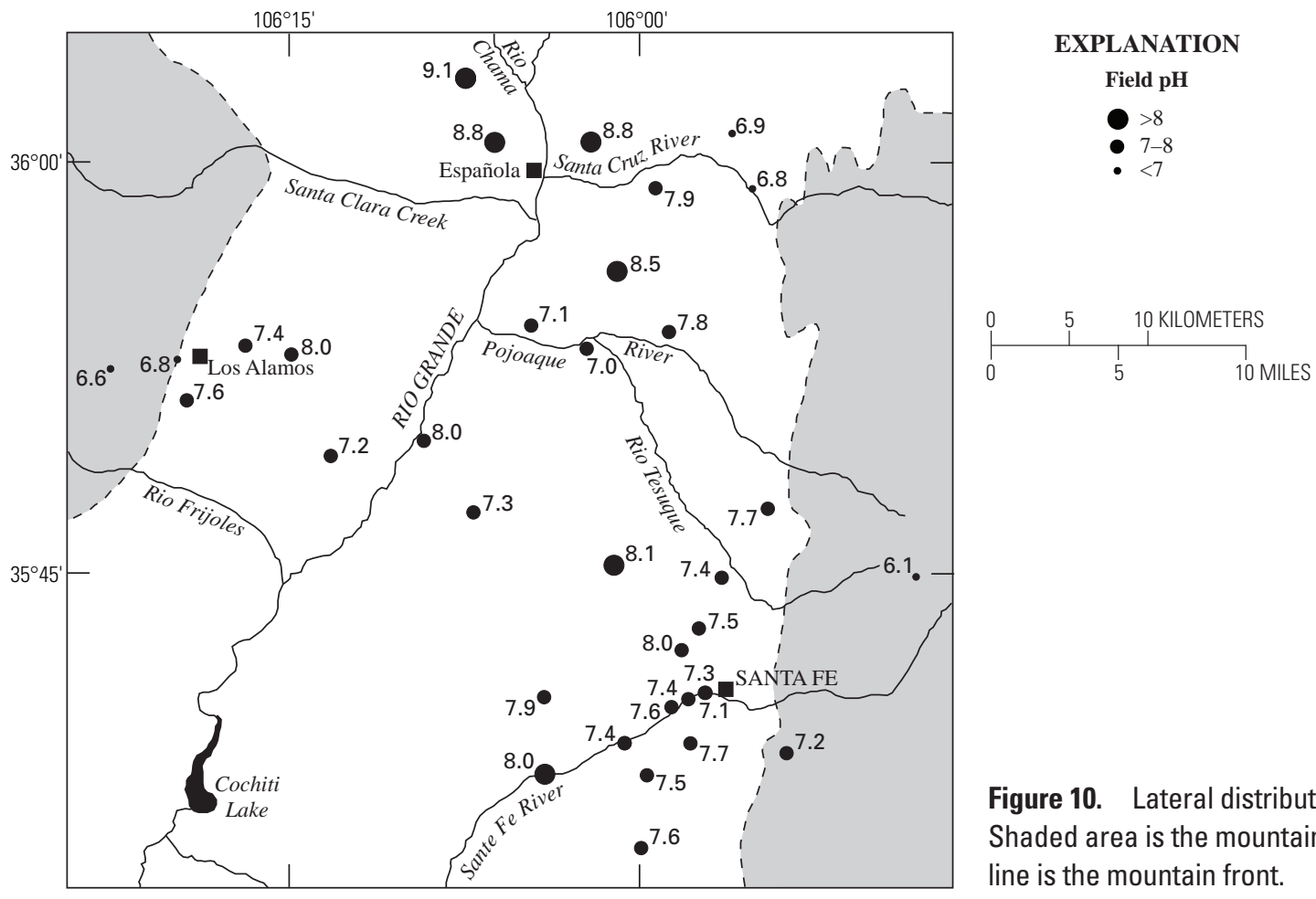

Figure 10. Lateral distribution of $\mathrm{pH}$. Shaded area is the mountain block; dashed line is the mountain front.
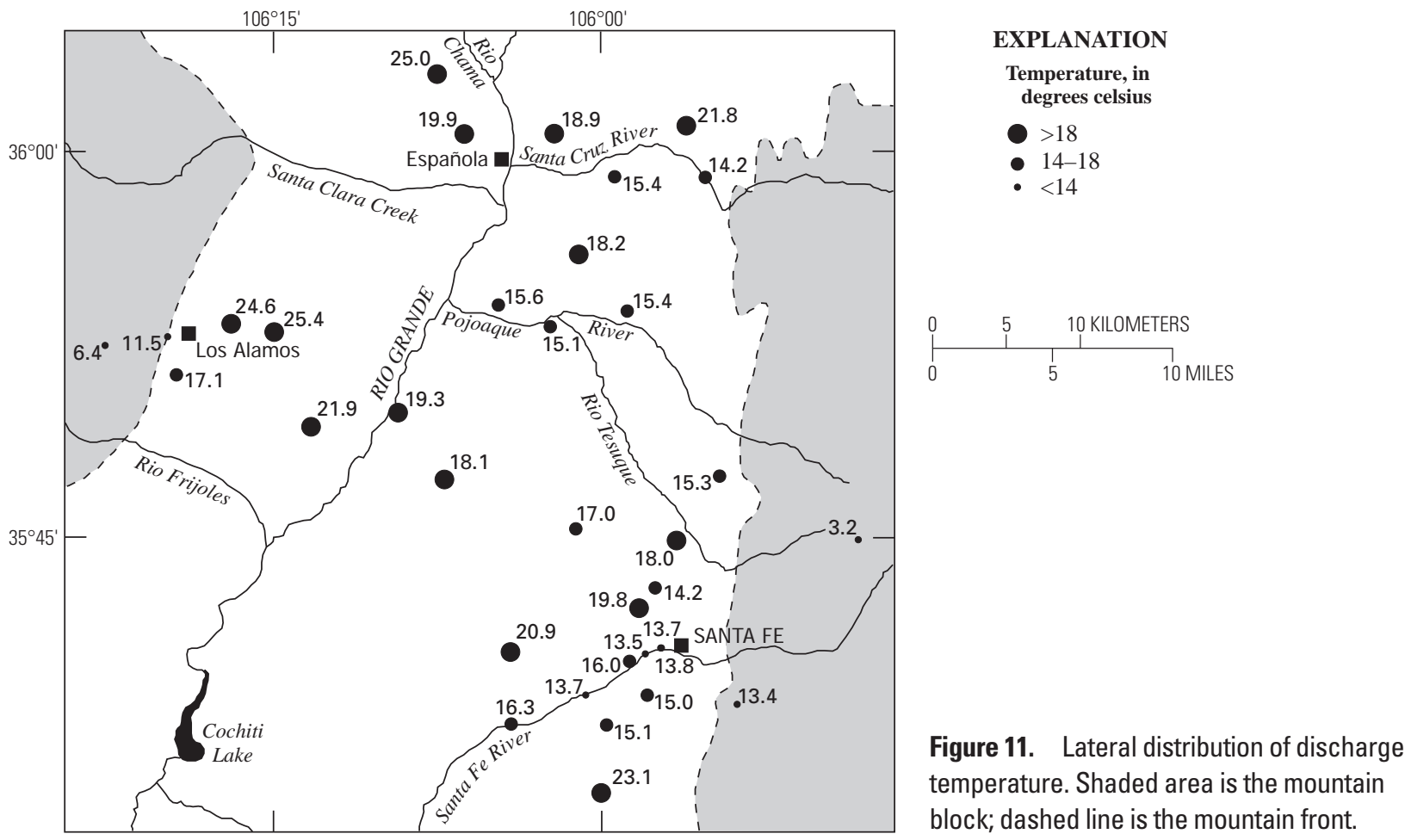


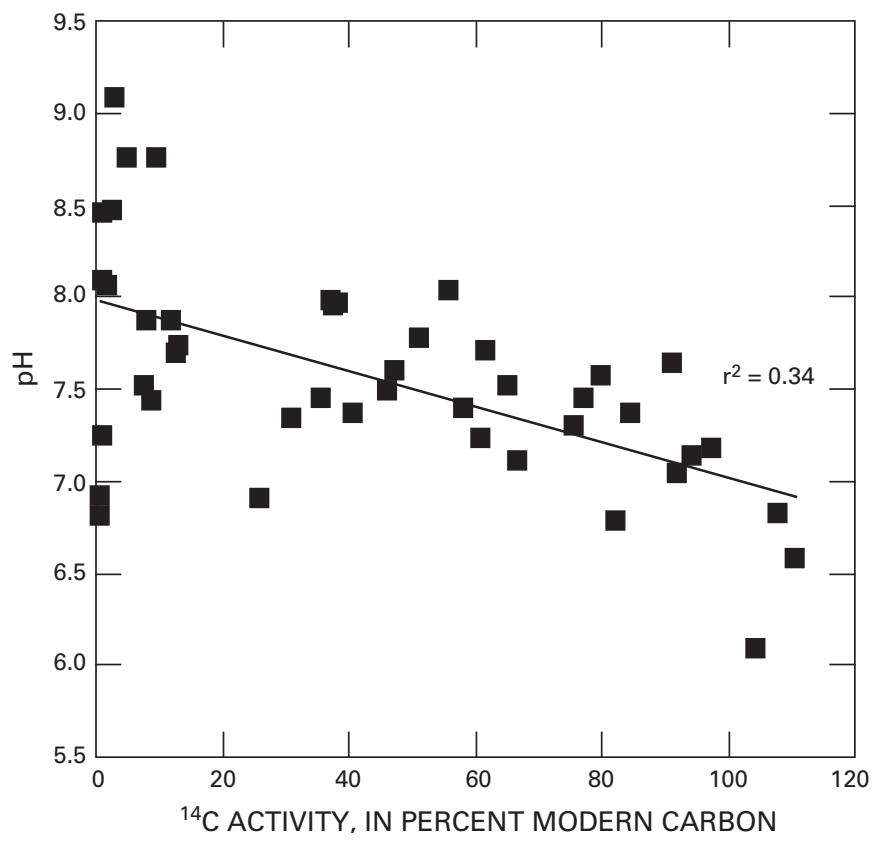

Figure 12. $\mathrm{pH}$ versus ${ }^{14} \mathrm{C}$ activity of dissolved inorganic carbon.

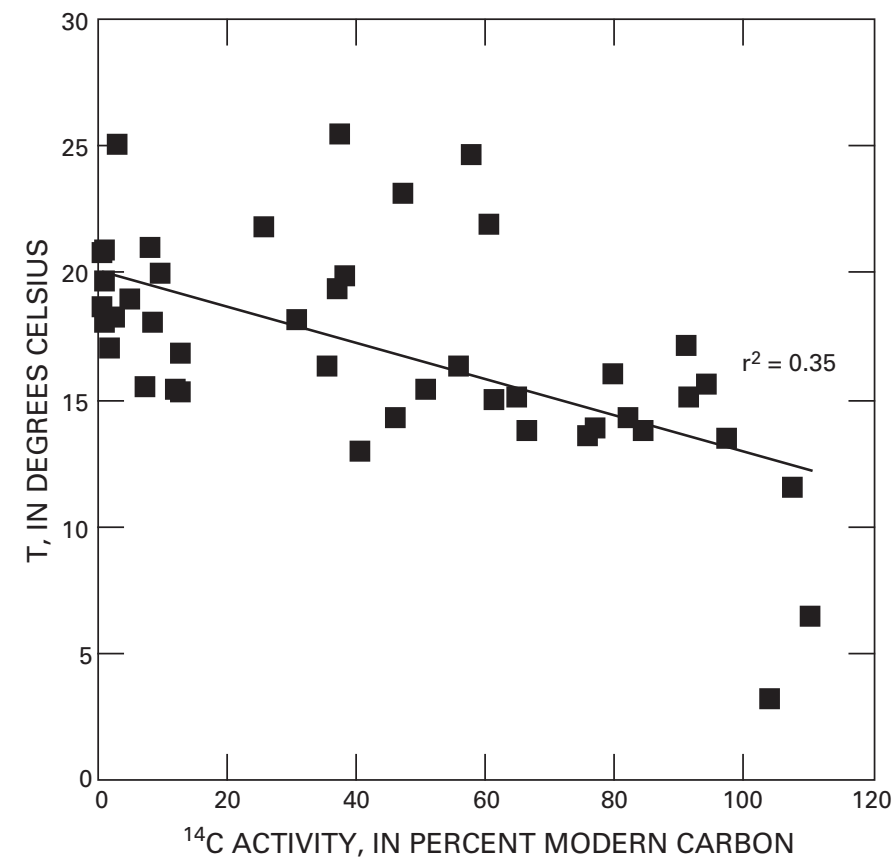

Figure 13. Discharge temperature $(\mathrm{T})$ versus ${ }^{14} \mathrm{C}$ activity of dissolved inorganic carbon.

recharged during or after the 1950s. Human-impacted waters in the Santa Fe vicinity were previously identified by Anderholm (1994) based on elevated $\mathrm{Cl}$ and $\mathrm{NO}_{3}$ concentrations. Most of the samples plotting well to the right of the ET trend line in figure 20 are human impacted.

Brines that have acquired very high dissolved mineral and $\mathrm{CO}_{2}$ concentrations through extended interaction with Mesozoic and Paleozoic sedimentary rocks underlying the Tesuque Formation (Read and others, 2000; Koning, 2002) may occur at depth throughout the basin. A brine discharges from a well near Chimayo in the northeastern part of the basin, periodically erupting as a cold $\mathrm{CO}_{2}$ geyser (Roberts Geyser). Details on Roberts Geyser can be found in Cumming (1997). Several workers familiar with Española Basin ground water were interviewed, and none were aware of any other brine-type ground water discharging at the surface in the basin. Plummer and others (2004a) observed brines discharging locally in the MRGB and suspected that several ground-water samples contained a fraction of brine water based on their low $\mathrm{SO}_{4} / \mathrm{Cl}$ ratios. Table 6 lists the major ion and isotopic composition of the brine from the Roberts Geyser (from Cumming, 1997) and from a representative brine in the MRGB, Saline 2 (from Plummer and others, 2004a). These brine samples provide the best available approximation of the chemical and isotopic composition of brines potentially occurring at depth throughout the Española Basin. Cl concentrations are $500-600 \mathrm{mg} / \mathrm{L}$, and $\mathrm{Cl}$ is highly enriched relative to $\mathrm{SO}_{4} ; \mathrm{SO}_{4} / \mathrm{Cl}$ mass ratios are $0.2-0.4$ compared to approximately 6 along the ET trend line in figure 20. Mixing with upward-leaking brines is therefore another possible explanation for samples plotting to the right of the ET trend line in figure 20, particularly those that are not human-impacted. The vertical $\mathrm{Cl}$ distribution shown in figure 18 is consistent with both a shallow source of $\mathrm{Cl}$ (human impacted waters) and a deep source of $\mathrm{Cl}$ (brine).

Alkalinity (as $\mathrm{CaCO}_{3}$ ) ranges from 11.4 to $708.0 \mathrm{mg} / \mathrm{L}$, with a mean of $164.9 \mathrm{mg} / \mathrm{L}$. Alkalinity is generally the highest in the northeast, lowest on the Pajarito Plateau, and variable in the southeast (fig. 21). As with the specific conductance, alkalinity decreases slightly with depth in piezometer nests closer to the mountain front (FAIR and ARCH1), and increases with depth in piezometer nests farther from the mountain front (SF2, SF6, and SFR) (fig. 22). Alkalinity is not well correlated with the ${ }^{14} \mathrm{C}$ activity. However, the highest alkalinities ( $>400 \mathrm{mg} / \mathrm{L}$ ) are observed in the deepest intervals of the two nested piezometers closest to the Rio Grande (SF2B, SF6A, and SF6B), where ${ }^{14} \mathrm{C}$ activities are $<2 \mathrm{pmC}$ and the oldest waters are expected to occur. High alkalinities are potentially indicative of extensive carbonate-mineral dissolution, which might lead to large adjustments to radiocarbon ages if occurring after recharge.

Ca concentrations range from 1.90 to $124.02 \mathrm{mg} / \mathrm{L}$, with a mean of $28.56 \mathrm{mg} / \mathrm{L}$. The spatial distribution of Ca displays no clear patterns, and $\mathrm{Ca}$ is not well correlated with ${ }^{14} \mathrm{C}$ activity.

Na concentrations range from 2.31 to $275.00 \mathrm{mg} / \mathrm{L}$, with a mean of $55.22 \mathrm{mg} / \mathrm{L}$. Na concentrations are generally highest in the northeast, lowest on the Pajarito Plateau, and intermediate in the southeast (fig. 23). Na concentrations increase with depth in the nested piezometers with the exception of the shallowest intervals in FAIR and ARCH1 (fig. 24). Na concentration is clearly correlated with ${ }^{14} \mathrm{C}$ activity (fig. $25, \mathrm{r}^{2}=0.47$ ), suggesting that $\mathrm{Na}$ increases with residence time in the saturated zone. $\mathrm{Na}$ is enriched relative to $\mathrm{Cl}$ in nearly all samples (fig. 26), so the addition of $\mathrm{Na}$ is not due to ET or halite dissolution, as expected. The addition of $\mathrm{Na}$ must instead be due to either dissolution of plagioclase or $\mathrm{Ca}-\mathrm{Na}$ cation exchange. The $(\mathrm{Na}+\mathrm{K}) / \mathrm{Ca}$ mass ratio is negatively correlated with the ${ }^{14} \mathrm{C}$ activity (fig. $27, \mathrm{r}^{2}=0.44$ ), consistent with waters in the basin generally evolving from $\mathrm{Ca} / \mathrm{CO}_{3}+\mathrm{HCO}_{3}$ to $\mathrm{Na} / \mathrm{CO}_{3}+\mathrm{HCO}_{3}$ with increasing residence time. $\mathrm{Na}$ is well correlated with $\mathrm{HCO}_{3}$ (fig. $28, \mathrm{r}^{2}=0.64$ ), and the $\mathrm{Na} / \mathrm{HCO}_{3}$ mole 


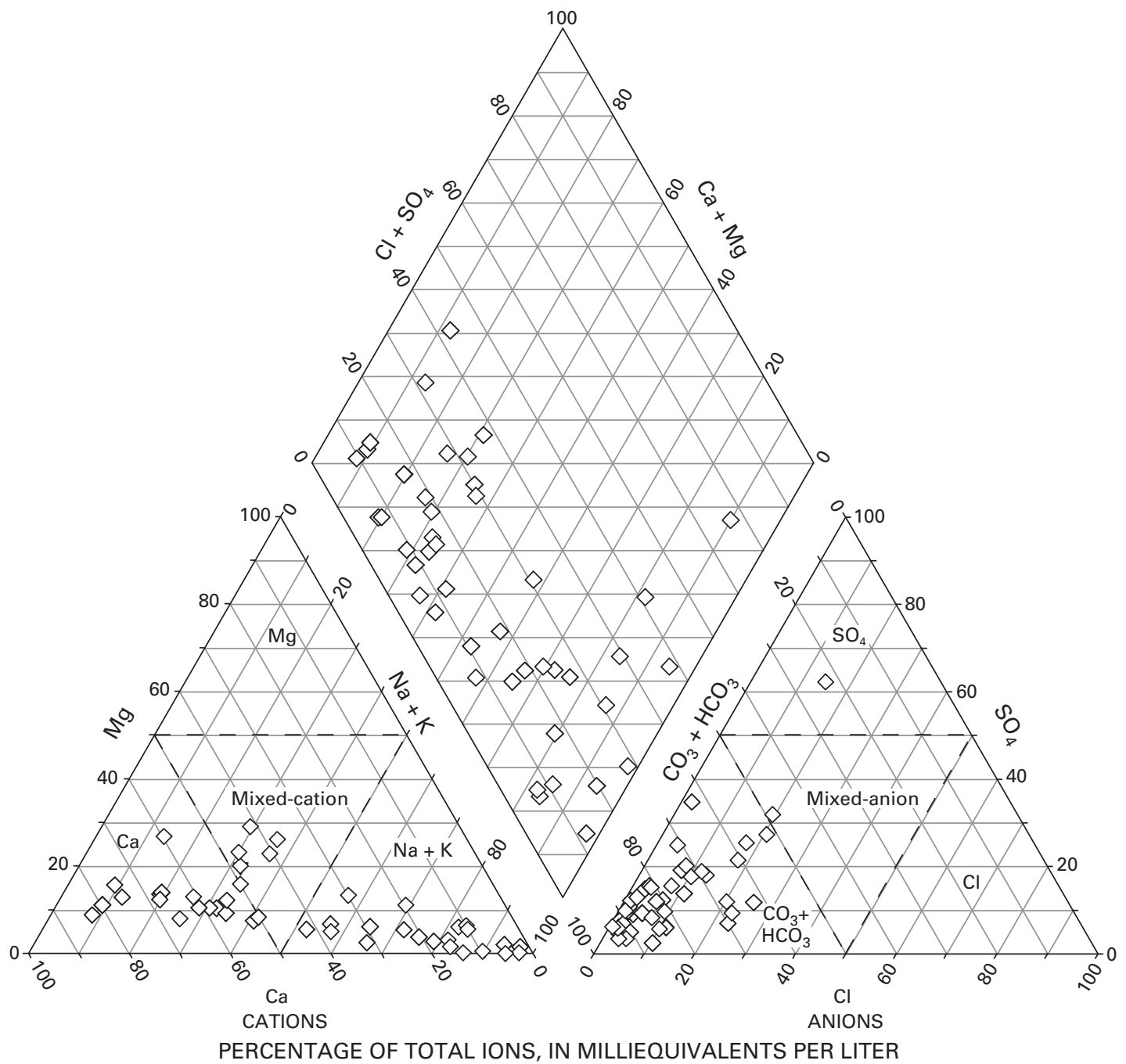

Figure 14. Piper diagram for sampled waters.

ratio is on average close to unity. These relationships suggest that the addition of $\mathrm{Na}$ is primarily due to $\mathrm{Ca}-\mathrm{Na}$ cation exchange, although plagioclase dissolution may also be locally significant. Cation exchange is an important reaction to consider in the interpretation of radiocarbon ages because removal of $\mathrm{Ca}$ allows for additional dissolution of calcite (typically with a very low ${ }^{14} \mathrm{C}$ activity), if available. The Tesuque Formation in the Española Basin contains 34 percent clay and siltstone, overall (Cavazza, 1986), meaning that clays with high ion-exchange capacities are likely present in much of the basin.

Mean concentrations of $\mathrm{Mg}, \mathrm{K}$, and $\mathrm{CO}_{3}(<5 \mathrm{mg} / \mathrm{L})$ are well below those of the other major ions discussed above. Reactions involving these ions probably have only a minor influence on DIC, and are therefore not discussed here.

\section{$\mathrm{H}, \mathrm{O}$, and $\mathrm{C}$ Isotopes}

$\delta^{2} \mathrm{H}$ and $\delta^{18} \mathrm{O}$ data were only collected for the nested piezometer samples, samples from the Pajarito Plateau, BECK'S SPRING, and WHOTCH-01. Measured $\delta^{2} \mathrm{H}$ values range from -72.31 to $-116.59 \%$, with a mean of $-88.75 \%$. Measured $\delta^{18} \mathrm{O}$ values range from -10.54 to $-15.78 \%$, with a mean of $-12.79 \%$. Data coverage is too limited to identify horizontal spatial patterns. Vertical trends are apparent in the nested piezometer samples, however, with $\delta^{2} \mathrm{H}$ and $\delta^{18} \mathrm{O}$ values generally decreasing with depth in piezometers farther from the mountain front (SF2, SF6, and SFR) and remaining constant or slightly increasing with depth in piezometers closer to the mountain front (FAIR and ARCH1) (figs. 29 and 30). Samples with the lowest ${ }^{14} \mathrm{C}$ activities $(<5 \mathrm{pmC})$ have $\delta^{2} \mathrm{H}$ and $\delta^{18} \mathrm{O}$ values from -104 to $-117 \%$ and from -14.3 to $-15.8 \%$, respectively (figs. 31 and 32 ). These $\delta^{2} \mathrm{H}$ and $\delta^{18} \mathrm{O}$ values are distinctly lighter than those for the rest of the samples, which range mostly from -75 to $-85 \%$ and from -11 to $-13 \%$, respectively. These relationships suggest that the oldest waters deeper in the aquifer and farther from the mountain front have distinctly lighter $\delta^{2} \mathrm{H}$ and $\delta^{18} \mathrm{O}$ values. This could result from these waters recharging at higher elevations than younger shallower waters, or from these waters recharging >11,550 yr ago during the Pleistocene Epoch when the climate was cooler. In the MRGB to the south of the Española Basin, similar isotopically depleted water was found with radiocarbon ages $\geq 20,000$ yr (Plummer and others, 2004a,b). 


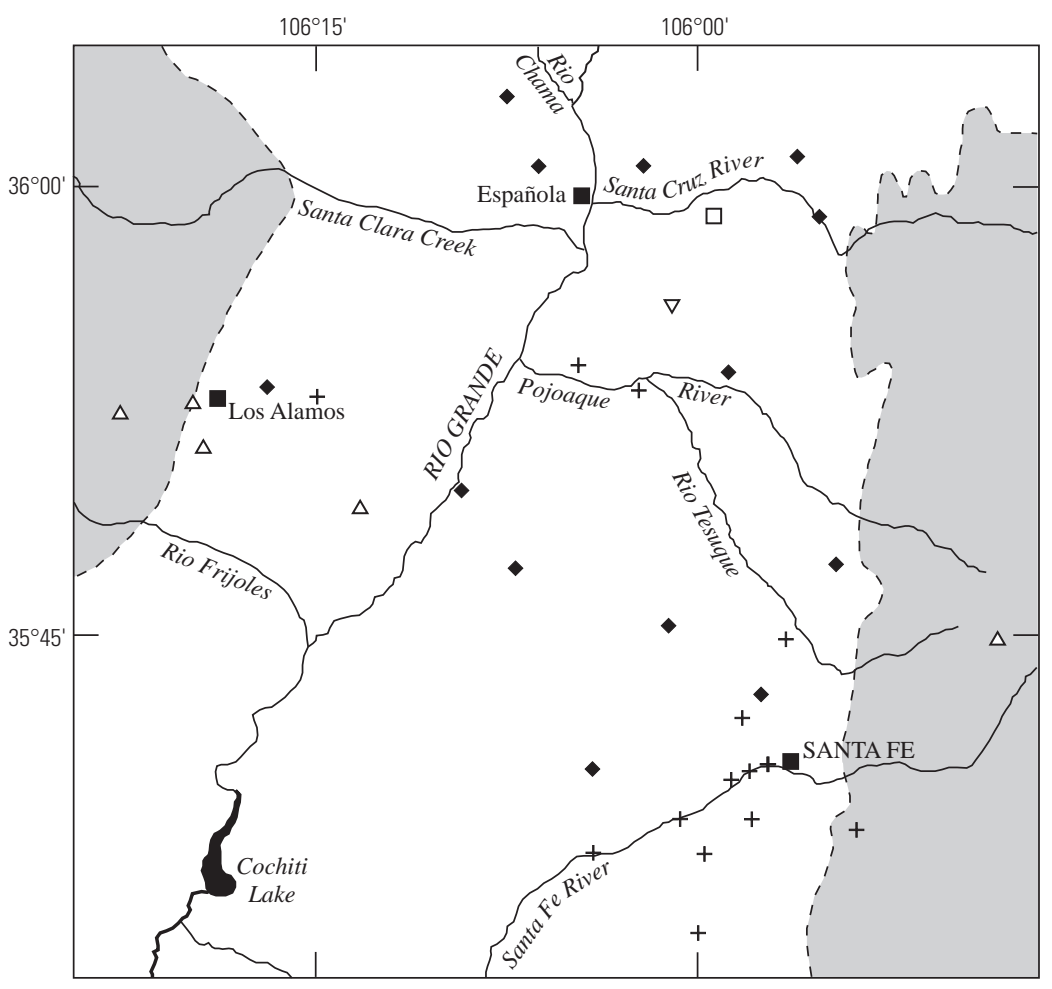

\section{EXPLANATION}

Water type

$+\mathrm{Ca} / \mathrm{CO}_{3}+\mathrm{HCO}_{3}$

$\Delta$ Mixed-cation $/ \mathrm{CO}_{3}+\mathrm{HCO}_{3}$

- $\mathrm{Na}+\mathrm{K} / \mathrm{CO}_{3}+\mathrm{HCO}_{3}$

$\square \mathrm{Na}+\mathrm{K} /$ mixed-anion

$\nabla \mathrm{Na}+\mathrm{K} / \mathrm{SO}_{4}$

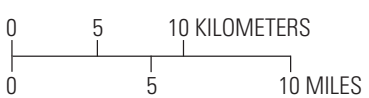

Figure 15. Lateral distribution of water type. Shaded area is the mountain block; dashed line is the mountain front.

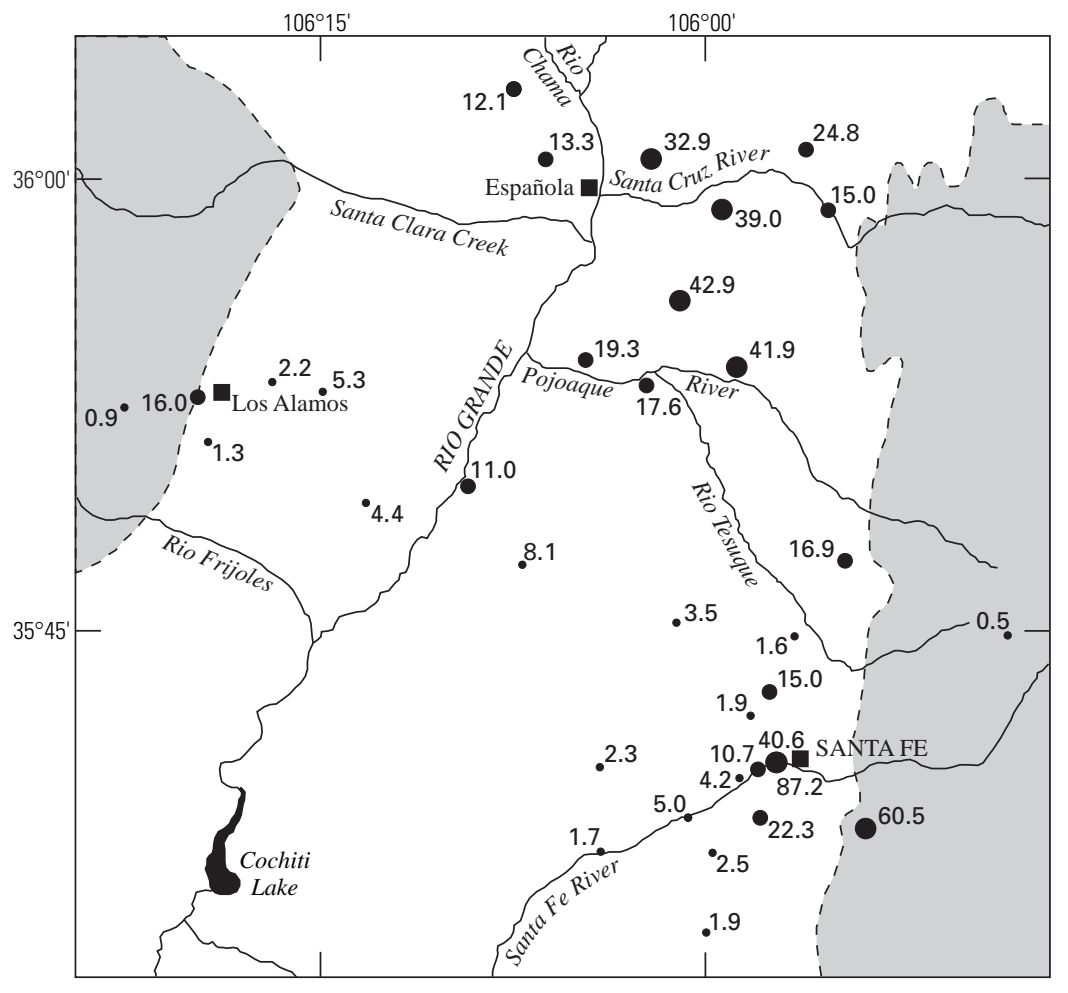

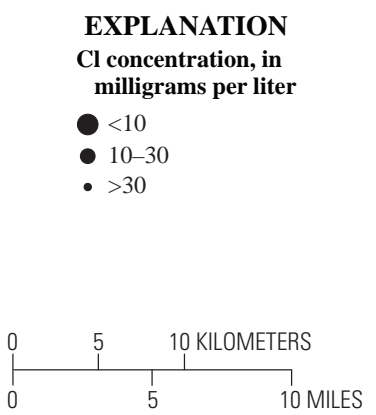

Figure 16. Lateral distribution of $\mathrm{Cl}$ concentration. Shaded area is the mountain block; dashed line is the mountain front. 

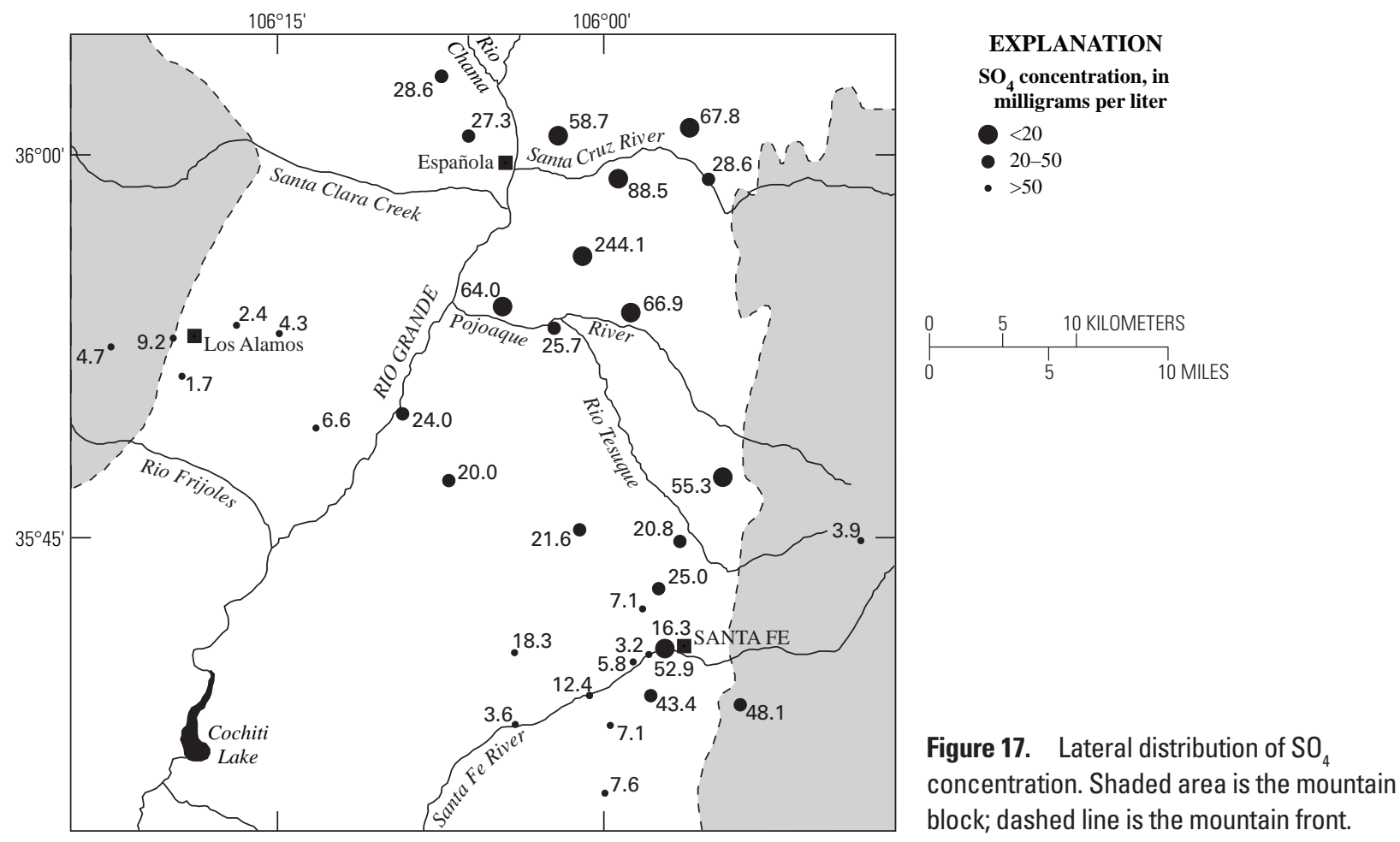
block; dashed line is the mountain front.

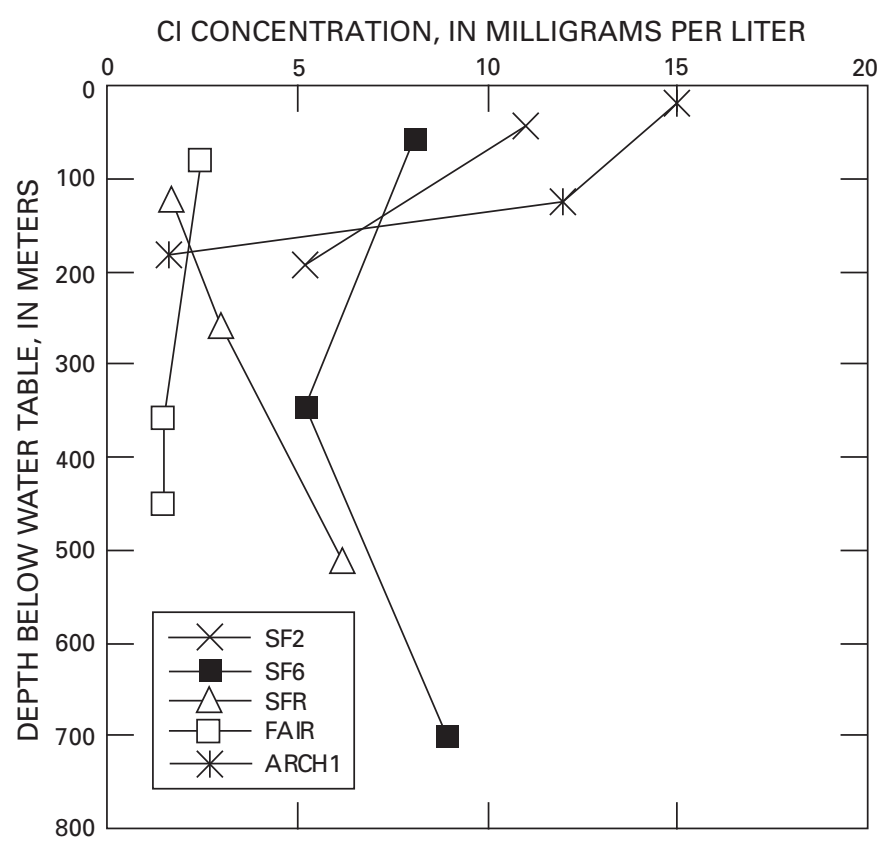

Figure 18. Vertical distribution of $\mathrm{Cl}$ in nested piezometers.

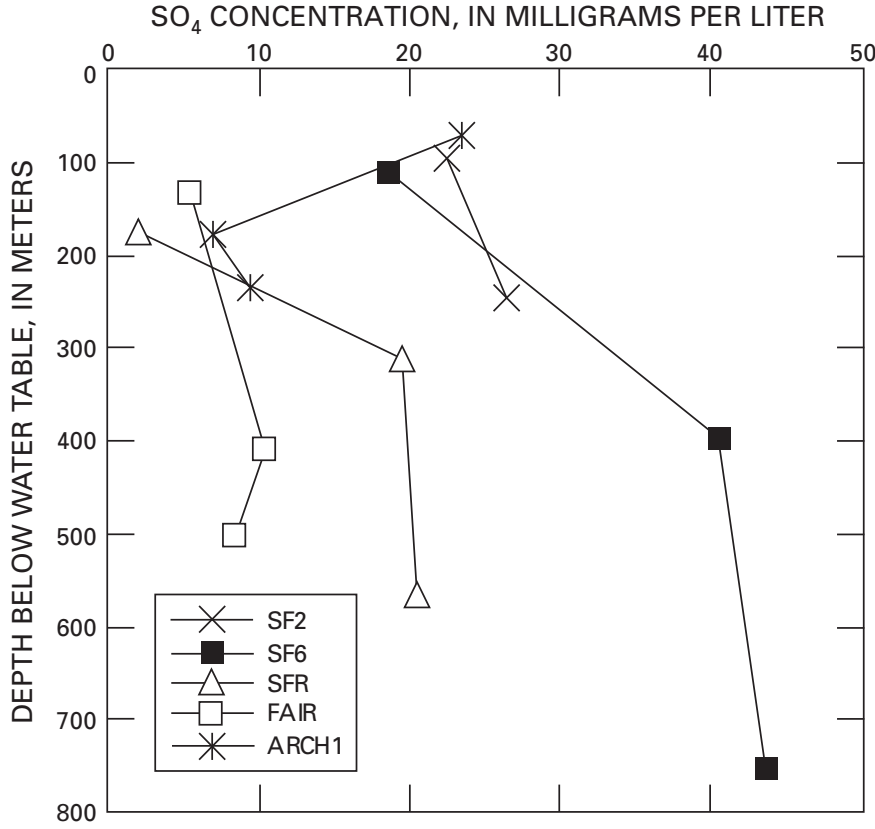

Figure 19. Vertical distribution of $\mathrm{SO}_{4}$ in nested piezometers. 


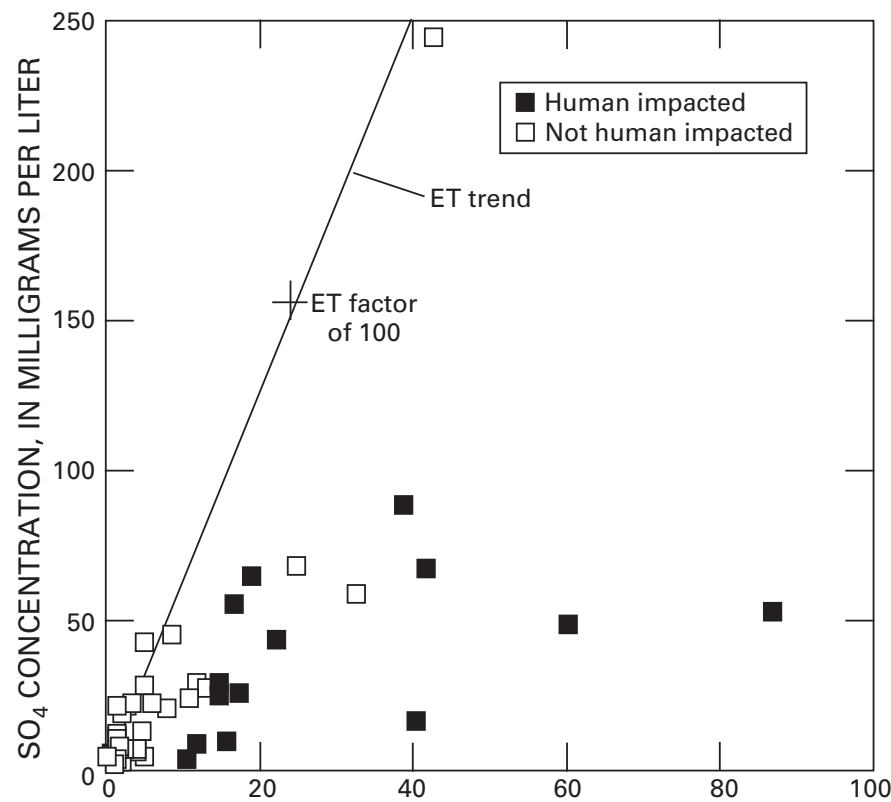

CI CONCENTRATION, IN MILLGRAMS PER LITER

Figure 20. $\mathrm{Cl}$ concentration versus $\mathrm{SO}_{4}$ concentration. Evapotranspiration (ET) trend line for bulk atmospheric deposition collected at the Sevilleta National Wildlife Refuge at the southern end of the Middle Rio Grande Basin (Plummer and others, 2004a).

Table 5. Samples apparently impacted by anthropogenic sources.

[TU, tritium units; $\mathrm{U}$, undetermined]

\begin{tabular}{lccc}
\hline \multicolumn{1}{c}{ Sample name } & $\begin{array}{c}\mathbf{C l} \\
(\mathbf{m g} / \mathbf{L})\end{array}$ & $\begin{array}{c}\mathbf{N O}_{\mathbf{3}} \text { as N } \\
(\mathbf{m g} / \mathbf{L})\end{array}$ & $\begin{array}{c}{ }^{3} \mathbf{H} \\
\text { (TU) }\end{array}$ \\
\hline WMWB44-01 & 60.48 & 2.125 & 3.88 \\
WLAOB-01 & 16.04 & 0.10 & 17.37 \\
WCHIM2-01 & 15.03 & 0.077 & 5.78 \\
WVALD1-01 & 38.97 & 3.657 & $<0.02$ \\
WDEV-01 & 17.60 & 0.005 & 7.92 \\
WBYN-01 & 41.86 & 3.333 & 1.84 \\
WBELL-01 & 19.28 & 1.418 & 3.89 \\
WARCH1B-01 & 12.0 & 5.419 & $\mathrm{U}$ \\
WARCH1C-01 & 15.0 & 2.032 & $\mathrm{U}$ \\
WMWA-01 & 40.56 & 0.462 & 5.98 \\
WMWB-02 & 87.17 & 11.510 & 4.24 \\
WSM-03 & 22.28 & 2.163 & 0.53 \\
WTOR-02 & 10.74 & 4.967 & 0.46 \\
WHOTCH-01 & 16.93 & 2.047 & 0.12 \\
\hline
\end{tabular}

The ${ }^{14} \mathrm{C}$ activities for DIC for replicate sample pairs WAS1-01/WAS1-01R and WAF-01/WAF-01R do not differ by more than about twice the reported 1- $\sigma$ error (table 4 ), as expected. $\delta^{13} \mathrm{C}$ values for DIC for these same replicate sample pairs do not differ by more than about $0.3 \%$, as expected.

$\delta^{13} \mathrm{C}$ values for DIC range from -2.81 to $-19.10 \%$, with a mean of $-10.42 \% .{ }^{14} \mathrm{C}$ activities for DIC range from 0.73 to $110.53 \mathrm{pmC}$, with a mean of $44.30 \mathrm{pmC} . \delta^{13} \mathrm{C}$ values are generally larger (heavier) farther from the mountain front and farther from rivers traversing the east side of the basin, suggesting a positive correlation with ground-water age (fig. 33). ${ }^{14} \mathrm{C}$ activities show a similar spatial pattern, but inverted, suggesting that age does indeed increase with distance from the mountain front and from rivers other than the Rio Grande (fig. 34). A correlation between $\delta^{13} \mathrm{C}$ and age is further supported by the clear correlation $\left(\mathrm{r}^{2}=0.46\right)$ between $\delta^{13} \mathrm{C}$ and ${ }^{14} \mathrm{C}$ activity (fig. 35). This correlation is consistent with progressive dissolution of carbonate minerals (with $\delta^{13} \mathrm{C}$ values $>-6 \%$ ) in the saturated zone, and suggests that radiocarbon age adjustments may be required for many of the samples. Note that plotting samples from different parts of the basin separately reveals the same general relationship between $\delta^{13} \mathrm{C}$ and ${ }^{14} \mathrm{C}$ activity, confirming that the distribution on figure 35 is probably not due simply to isotopic variations between ground waters occurring in different parts of the basin. Both $\delta^{13} \mathrm{C}$ and ${ }^{14} \mathrm{C}$ activity are clearly correlated with depth in the nested piezometer samples (figs. 36 and 37). $\delta^{13} \mathrm{C}$ values generally increase with depth, whereas ${ }^{14} \mathrm{C}$ activity generally decreases with depth, suggesting that ground-water ages generally increase with depth as expected.

\section{Hydrochemical Zones}

Ground water in the Española Basin was divided into four hydrochemical zones based on differences in the chemical and isotopic characteristics discussed above: West, Southeast, Northeast, and Central Deep (table 3, fig. 38). Hydrochemical zones were defined because differences in the chemical and isotopic composition of ground water in different parts of the basin probably reflect differences in aquifer materials and associated water-rock interactions. Such differences are potentially important in the process of developing geochemical models with NETPATH (Plummer and others, 1994).

Table 6. Chemical and isotopic composition of brines.

[Carbon isotopes measured on dissolved inorganic carbon; pmC, parts modern carbon; MRGB, Middle Rio Grande Basin; U, undetermined; Saline2 (Coyote Spring) data from Plummer and others (2004a); Robert's Geyser data from Cumming (1997)]

\begin{tabular}{|c|c|c|c|c|c|c|c|c|c|c|c|}
\hline \multicolumn{2}{|c|}{ Sample information } & \multirow[b]{2}{*}{$\mathrm{pH}$} & \multicolumn{7}{|c|}{ Major ions } & \multicolumn{2}{|c|}{ Carbon isotopes } \\
\hline Name & Location & & $\begin{array}{c}\text { Ca } \\
(\mathrm{mg} / \mathrm{L})\end{array}$ & $\begin{array}{c}\mathrm{Mg} \\
(\mathrm{mg} / \mathrm{L})\end{array}$ & $\begin{array}{c}\mathrm{Na} \\
(\mathrm{mg} / \mathrm{L})\end{array}$ & $\begin{array}{c}\mathrm{K} \\
(\mathrm{mg} / \mathrm{L})\end{array}$ & $\begin{array}{c}\mathrm{Cl} \\
(\mathrm{mg} / \mathrm{L})\end{array}$ & $\begin{array}{c}\mathrm{SO}_{4} \\
\text { (mg/L) }\end{array}$ & $\begin{array}{c}\text { Alkalinity } \\
\text { as } \mathrm{HCO}_{3} \\
(\mathrm{mg} / \mathrm{L})\end{array}$ & $\begin{array}{c}\delta^{13} \mathbf{C} \\
\text { (per mil) }\end{array}$ & $\begin{array}{c}{ }^{14} \mathrm{C} \text { activity } \\
\text { (pmC) }\end{array}$ \\
\hline Robert's Geyser & Española Basin & 6.51 & 483 & 203 & 1,110 & 35.1 & 506 & 182 & 3,910 & -0.55 & $\mathrm{U}$ \\
\hline
\end{tabular}

*Estimated value. 


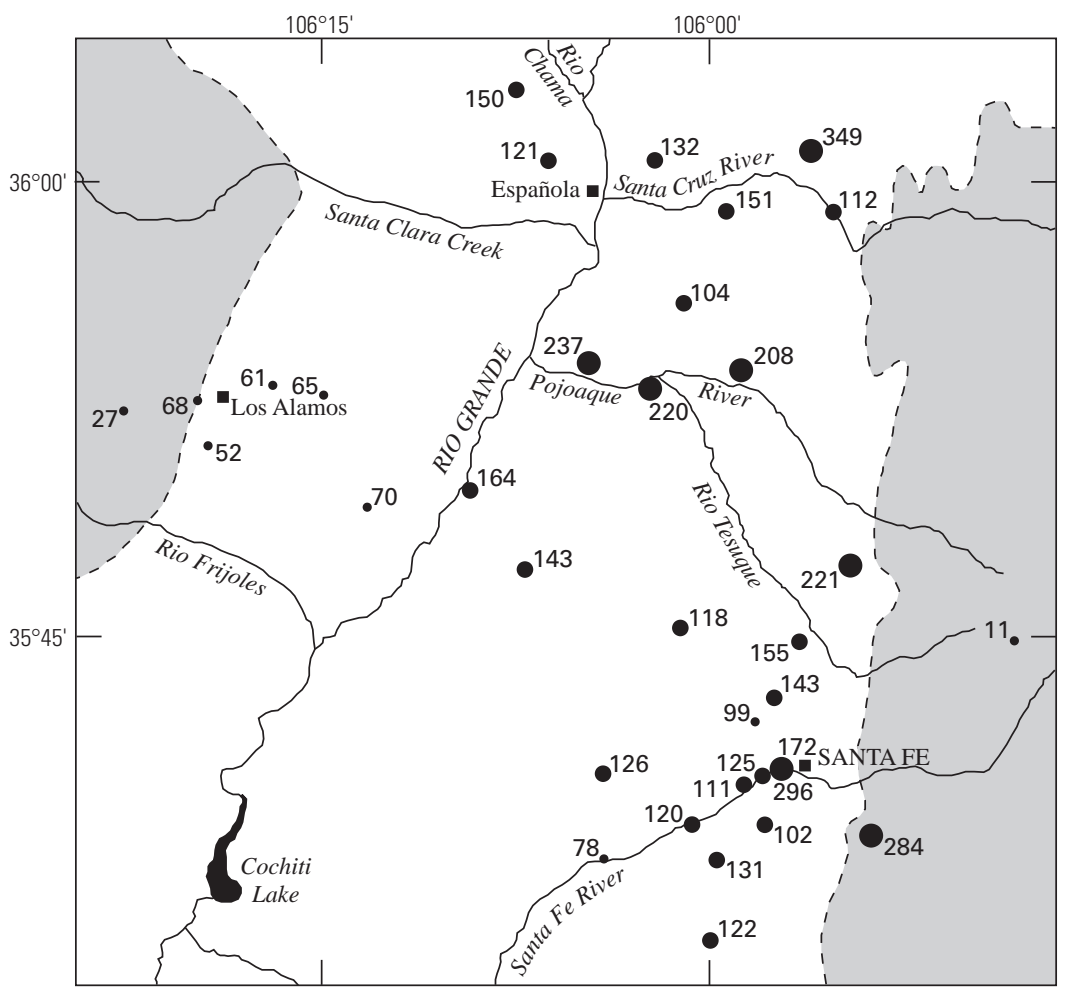

\section{EXPLANATION}

Lab alkalinity, in milligrams

per liters $\mathrm{CaCO}_{3}$

$>100$

- $100-200$

- $<200$

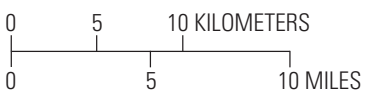

Figure 21. Lateral distribution of alkalinity. Shaded area is the mountain block; dashed line is the mountain front.

Lateral boundaries between hydrochemical zones are only approximate, given the limited data coverage; zone boundaries in reality may be broad and gradational. The lateral extent of the Central Deep zone is unknown, though it cannot extend farther to the southeast than the SFR piezometer nest. The Central Deep zone underlies the southeast zone (and perhaps portions of the Northeast and West zones) in the vicinity of the SF2 and SF6 piezometer nests; its upper limit is 100-200 m below the water table. Outside of this vicinity, the vertical extent of the hydrochemical zones is unknown.

Median values for selected chemical and isotopic parameters (table 7) illustrate distinguishing features of the different hydrochemical zones (see also figs. 7, 8, 15, 16, 17, 21, 23, and 33). Alkalinity and Na concentrations in the Central Deep zone are considerably higher than the other zones, suggesting that more $\mathrm{Ca}-\mathrm{Na}$ cation exchange and calcite dissolution have occurred in these waters. $\delta^{13} \mathrm{C}$ values are distinctly lower than in the other zones. This is consistent with significant dissolution of carbonate minerals of marine origin in the saturated zone, and implies that samples from the Central Deep zone probably require large radiocarbon age adjustments. In the West zone, alkalinity is lower and $\delta^{13} \mathrm{C}$ values are more negative than in the other zones, suggesting relatively little carbonate mineral dissolution. West zone samples generally have the lowest concentrations of all major ions (and TDS), consistent with relatively little mineral dissolution. In the Northeast zone, $\mathrm{Cl}$ and $\mathrm{SO}_{4}$ concentrations are higher than in the other zones. This may indicate that many Northeast zone waters have mixed with a brine or human-impacted water. Mixing with a brine is consistent with the presence of Roberts Geyser (brine-discharging well) in the Northeast zone. Na and TDS concentrations are higher than in the West and Southeast zones. This could be due to either more extensive Ca-Na cation exchange, or, again, mixing with a brine. Concentrations of dissolved constituents in the Southeast zone are generally intermediate between the West and Northeast zones, indicating moderate amounts of mineral dissolution and $\mathrm{Ca}-\mathrm{Na}$ cation exchange. $\mathrm{Cl}$ and TDS concentrations are locally elevated (particularly in the vicinity of Santa Fe), probably due to mixing with human-impacted waters.

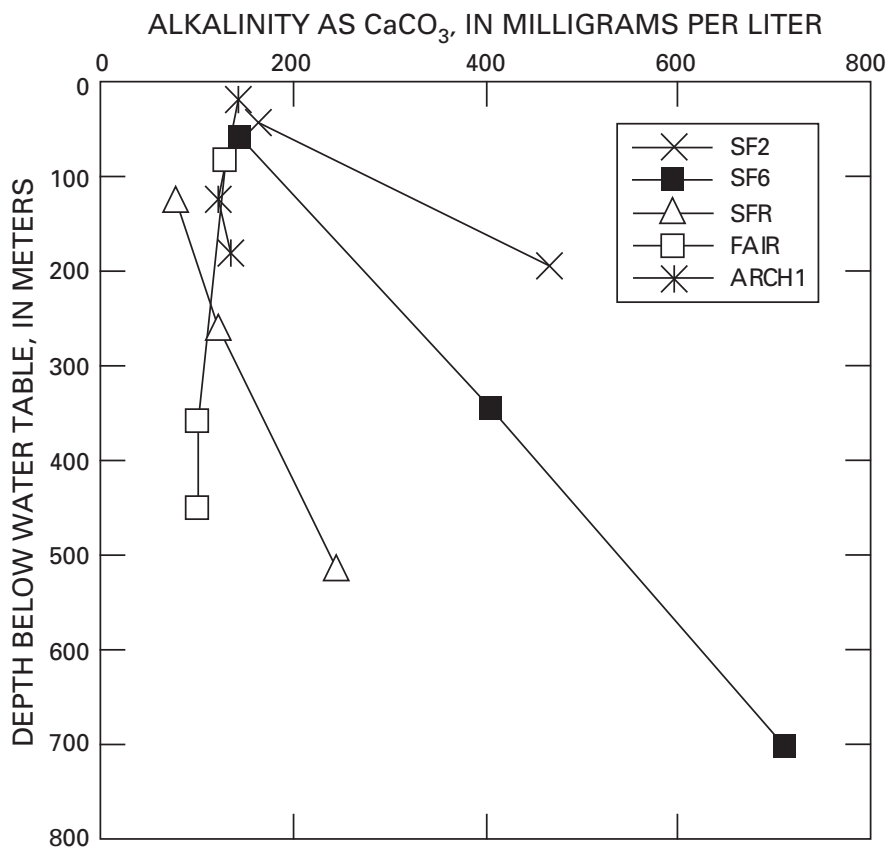

Figure 22. Vertical distribution of alkalinity in nested piezometers. 

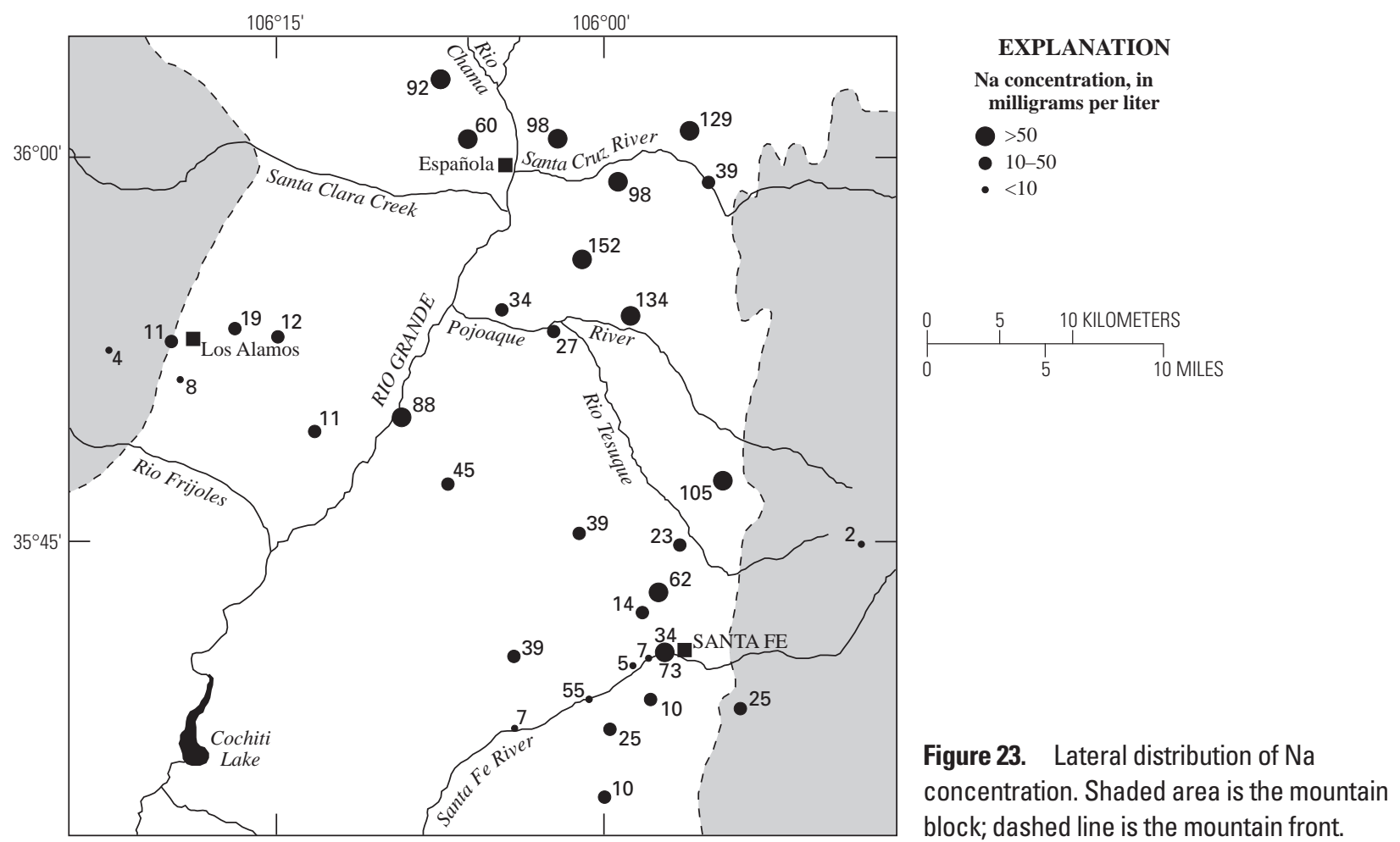

block; dashed line is the mountain front.

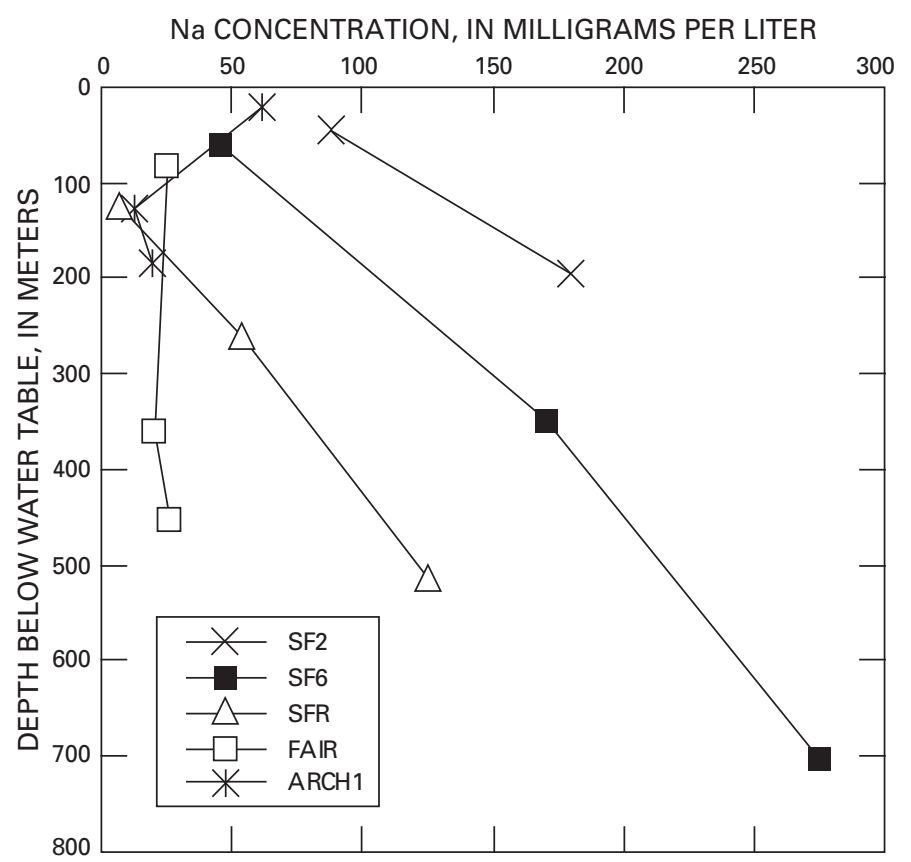

Figure 24. Vertical distribution of $\mathrm{Na}$ concentration in nested piezometers.

The hydrochemical zone divisions are consistent with the geology. The eastern extent of the West zone roughly corresponds with the eastern extent of the volcanic and volcaniclastic rocks of the Jemez Mountains and Pajarito Plateau. These rocks contain very little calcite and clay, probably explaining the generally low

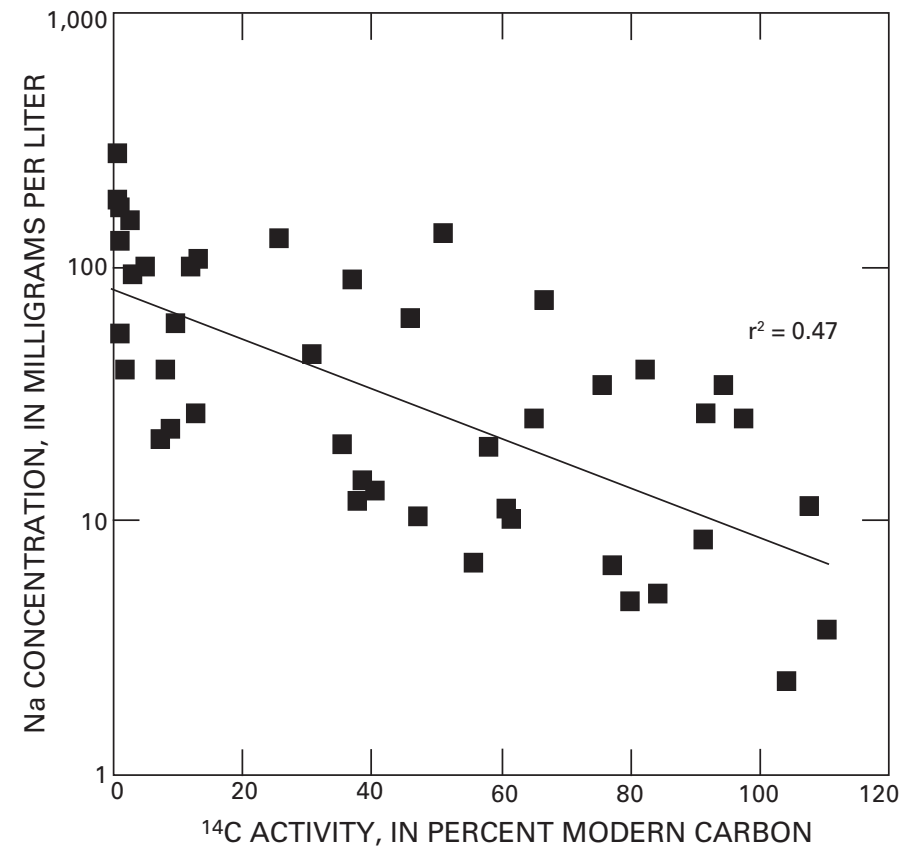

Figure 25. Na concentration versus ${ }^{14} \mathrm{C}$ activity of dissolved inorganic carbon.

concentrations of $\mathrm{HCO}_{3}$ and other ions, along with more negative $\delta^{13} \mathrm{C}$ values, in West-zone samples. Ground-water flow within the Northeast and Southeast zones mostly occurs within the Tesuque Formation, consisting of variably consolidated sandstone (45 percent), siltstone/claystone (34 percent), and pebble conglomerate 


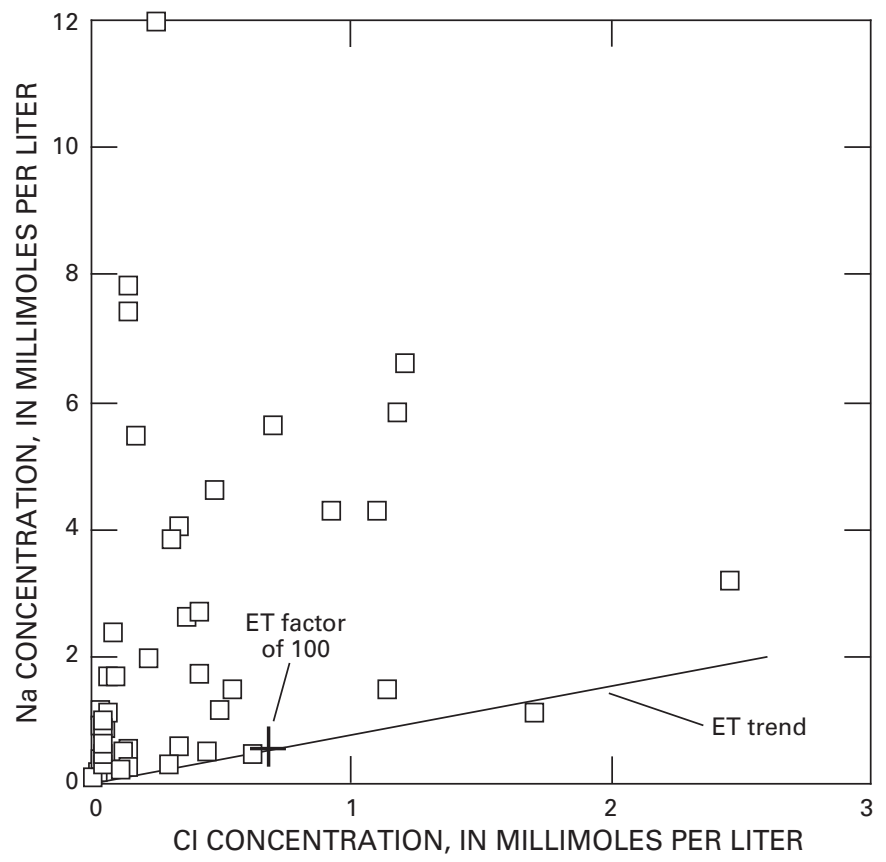

Figure 26. $\mathrm{Cl}$ concentration versus $\mathrm{Na}$ concentration. Evapotranspiration (ET) trend line for bulk atmospheric deposition collected at the Sevilleta National Wildlife Refuge at the southern end of the Middle Rio Grande Basin (Plummer and others, 2004a).

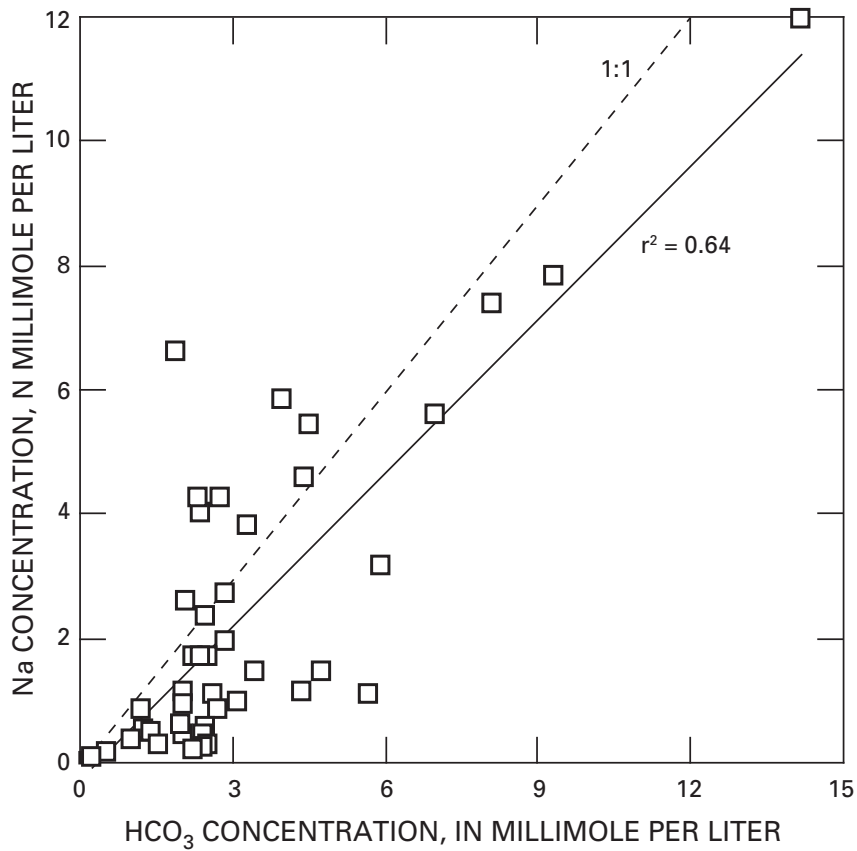

Figure 28. $\mathrm{HCO}_{3}$ concentration versus $\mathrm{Na}$ concentration.

(20 percent), with minor volcanic ash and carbonate (1 percent) (Cavazza, 1986). In the Española Basin, the Tesuque Formation is arkosic to subarkosic, generally composed of $>85$ percent quartz and feldspar and $<6$ percent sedimentary lithic grains (Cavazza, 1986; Koning and others, 2004). The Tesuque Formation has been subdivided into multiple lithosomes based on composition

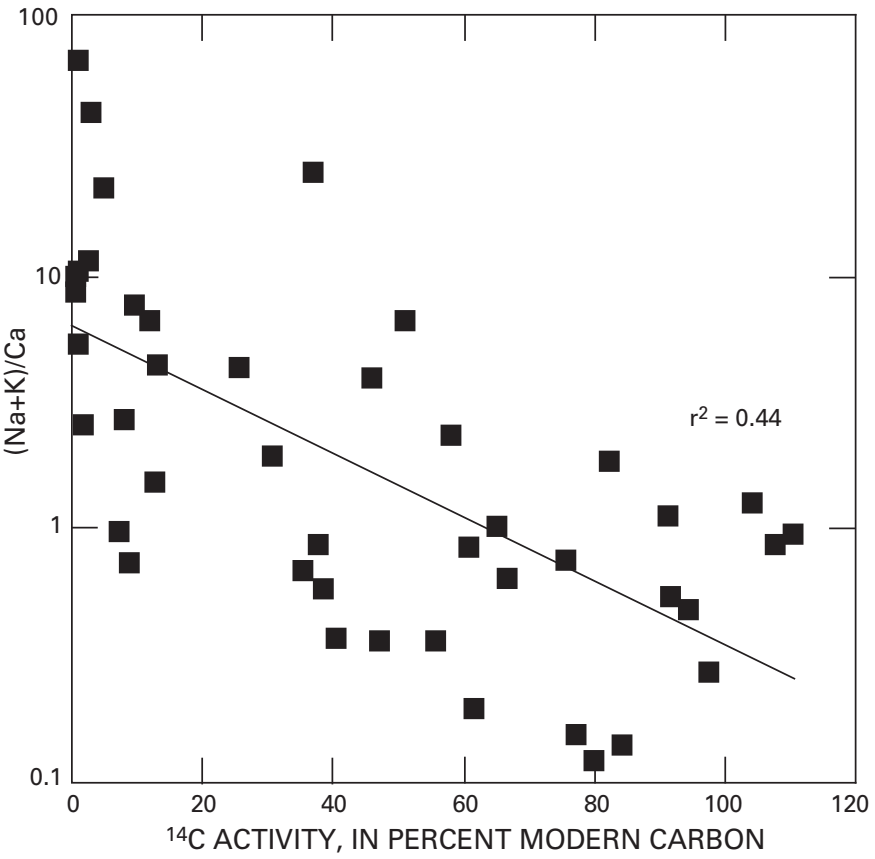

Figure 27. $(\mathrm{Na}+\mathrm{K}) / \mathrm{Ca}$ mass ratio versus ${ }^{14} \mathrm{C}$ activity of dissolved inorganic carbon.

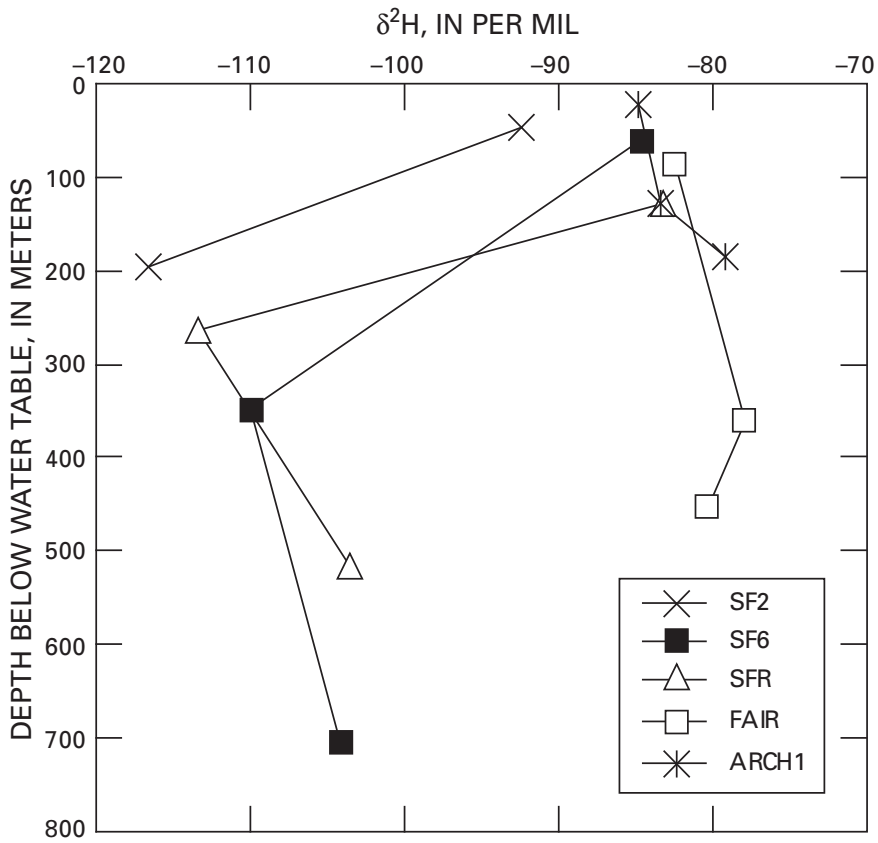

Figure 29. Vertical distribution of $\delta^{2} \mathrm{H}$ in nested piezometers.

and origin (Cavazza, 1986; Koning, 2002; Koning and others, 2004). Lithosome A occurs along the eastern edge of the basin, at the foot of the Sangre de Cristo Mountains. Lithosome A consists of arkosic sandstone (on average 97 percent quartz and feldspar) and pebbly conglomerate (on average 84 percent quartz, feldspar, and granitic clasts) with few claystones and lithic sedimentary 


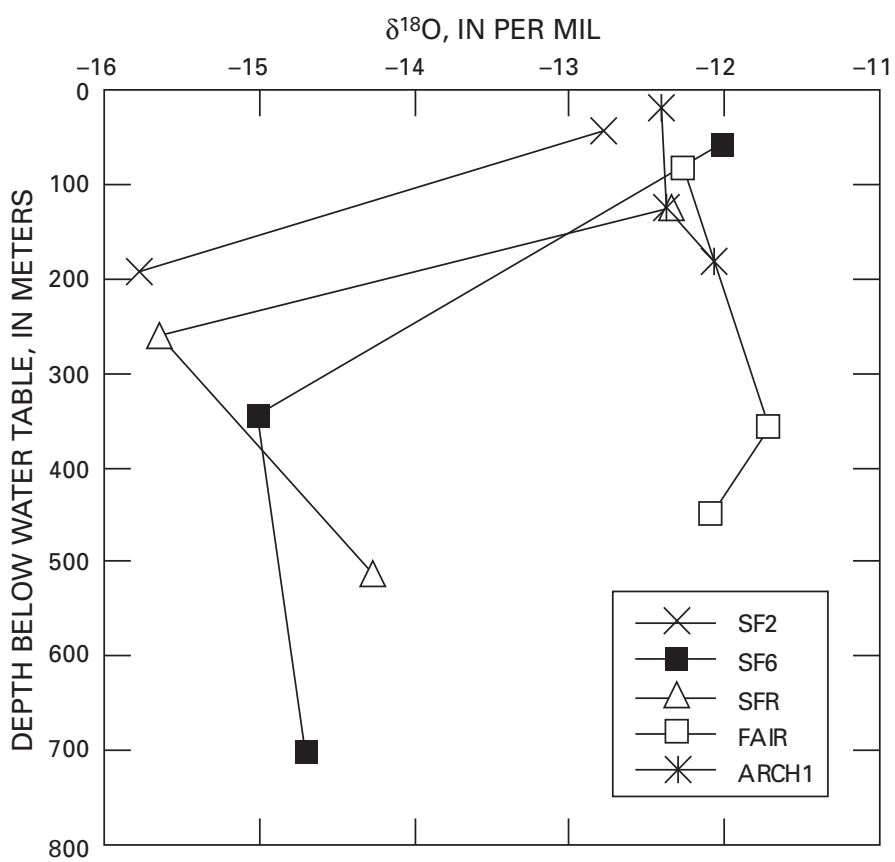

Figure 30. Vertical distribution of $\delta^{18} 0$ in nested piezometers.

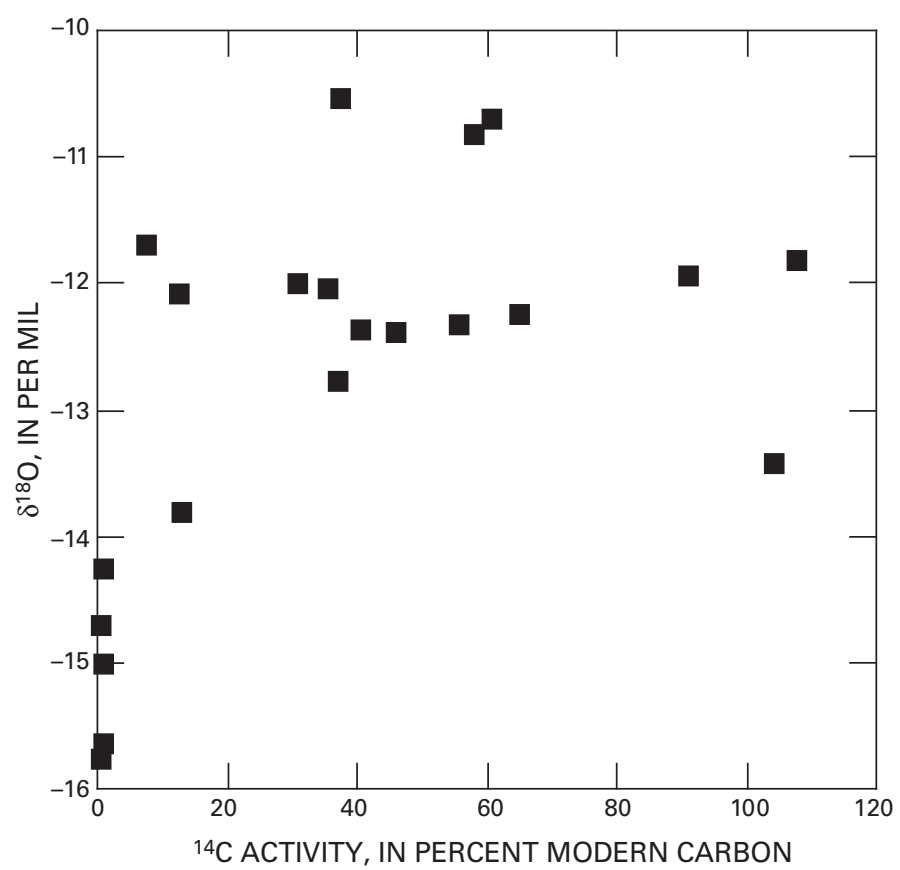

Figure 32. $\quad \delta^{18} \mathrm{O}$ versus ${ }^{14} \mathrm{C}$ activity of dissolved inorganic carbon.

clasts (on average $<2$ percent). In the Northeast zone, lithosome A grades laterally westward into lithosome B, and in the Southeast zone, lithosome A grades laterally westward and southward into lithosome $\mathrm{S}$. Therefore, in addition to mixing with a brine, differences in ground-water chemistry between the Northeast and Southeast zones may be related to differences between lithosomes B and S. Important compositional differences include (1) lithosome B was deposited in a lower energy environment than lithosome $\mathrm{S}$, and therefore contains less gravel and more

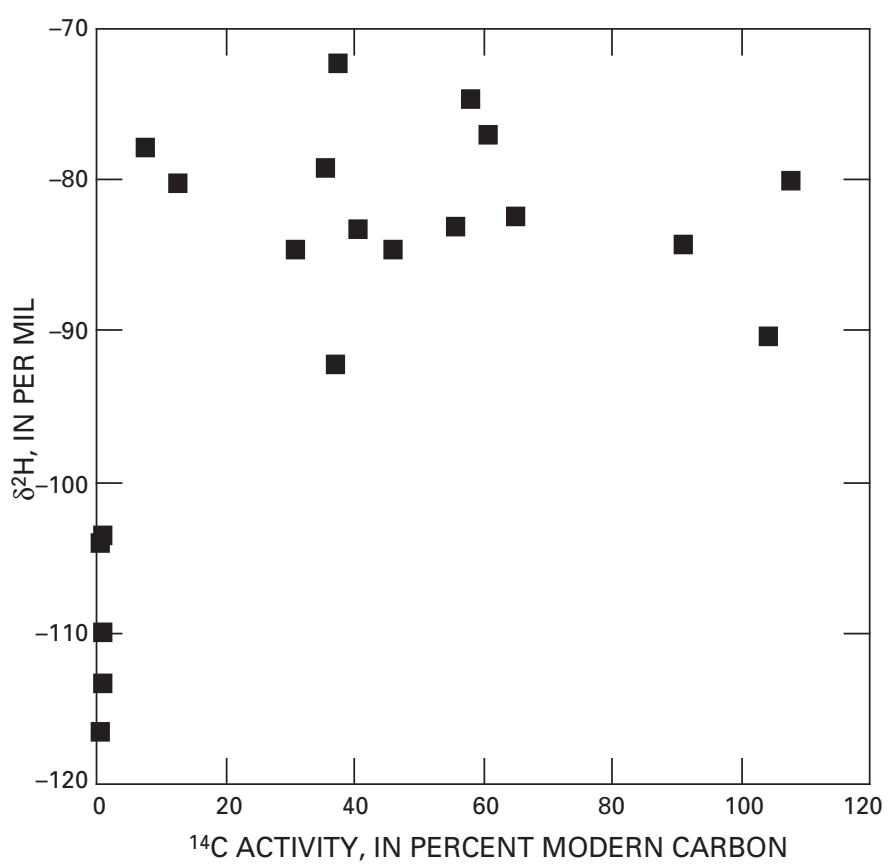

Figure 31. $\delta^{2} \mathrm{H}$ versus ${ }^{14} \mathrm{C}$ activity of dissolved inorganic carbon.

claystone and siltstone; (2) lithosome B typically contains more sedimentary lithic grains than lithosome $S$ (up to 6 percent versus up to 3 percent), and therefore is more likely to contain Paleozoic limestone fragments. The greater abundance of clays in lithosome B potentially explains $\mathrm{Na}$ concentrations being higher in the Northeast zone than the Southeast zone, with more clays allowing more $\mathrm{Ca}-\mathrm{Na}$ cation exchange. More fines might also contribute to the higher TDS concentrations in the Northeast zone. The greater abundance of sedimentary lithic fragments (including limestone) in lithosome B potentially contributes to higher $\mathrm{SO}_{4}$ concentrations in the Northeast zone than the Southeast zone; these fragments possibly containing gypsum.

\section{Radiocarbon Ages}

\section{Initial Carbon-14 Activity}

The dating clock in the ${ }^{14} \mathrm{C}$ dating method begins at the moment ground water enters the saturated zone and becomes isolated from the atmosphere and soil gas. At this moment, the ${ }^{14} \mathrm{C}$ activity of the DIC in the ground water is referred to as the initial ${ }^{14} \mathrm{C}$ activity, or $\mathrm{A}_{0}$. $\mathrm{A}_{0}$ must be known or estimated in order to calculate a ${ }^{14} \mathrm{C}$ age. The unadjusted ${ }^{14} \mathrm{C}$ age is calculated assuming $\mathrm{A}_{0}$ is $100 \mathrm{pmC}$, but reactions in the soil zone between DIC and soil carbonate and silicate minerals can result in $\mathrm{A}_{0}$ values substantially different (usually lower) than $100 \mathrm{pmC}$.

An apparently sensible approach to estimating $\mathrm{A}_{0}$ is to examine the ${ }^{14} \mathrm{C}$ activity of DIC in ground water that has resided in the saturated zone for a relatively short period of time (hundreds of years or less). Such waters are referred to 

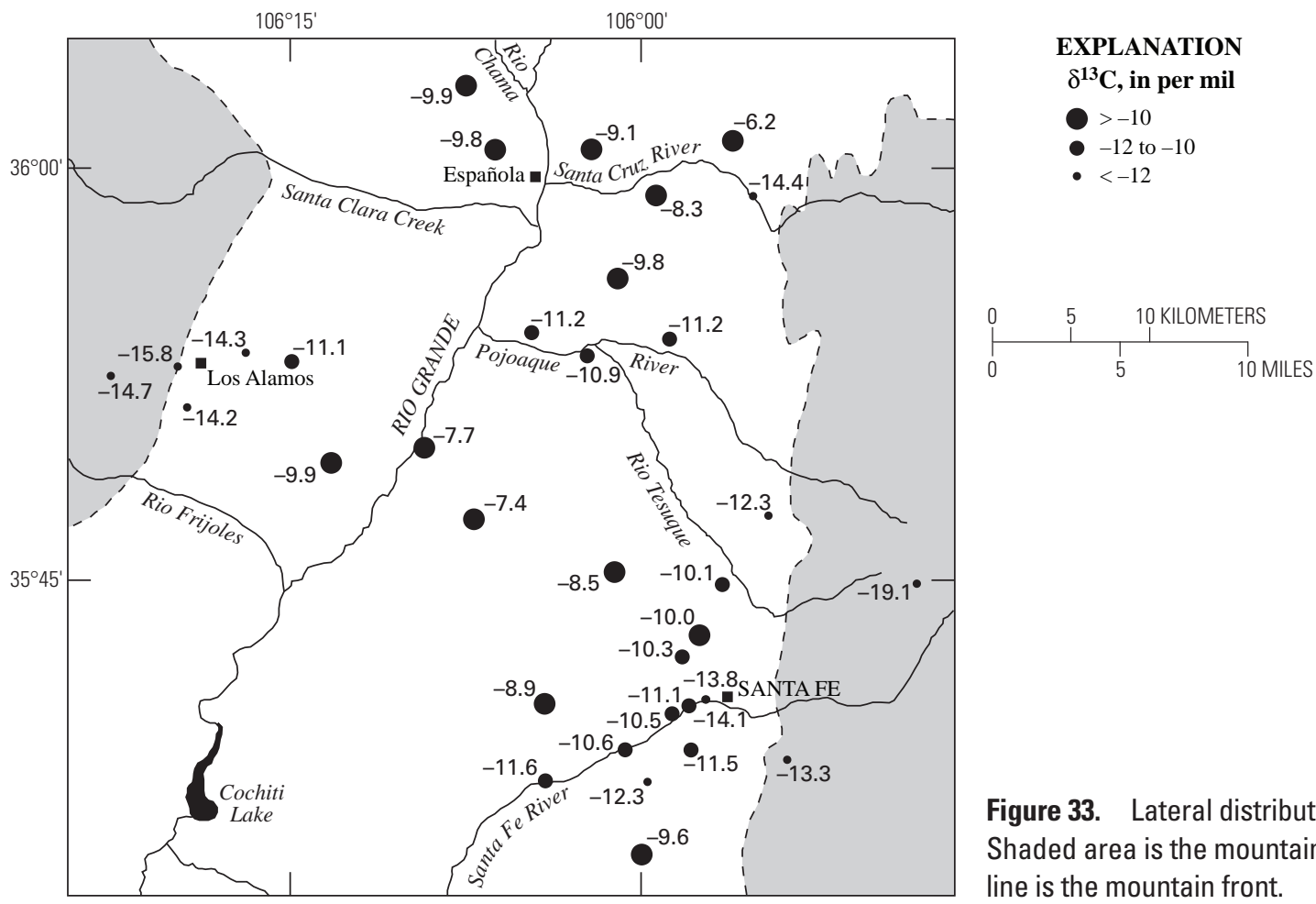

Figure 33. Lateral distribution of $\delta^{13} \mathrm{C}$.

Shaded area is the mountain block; dashed line is the mountain front.
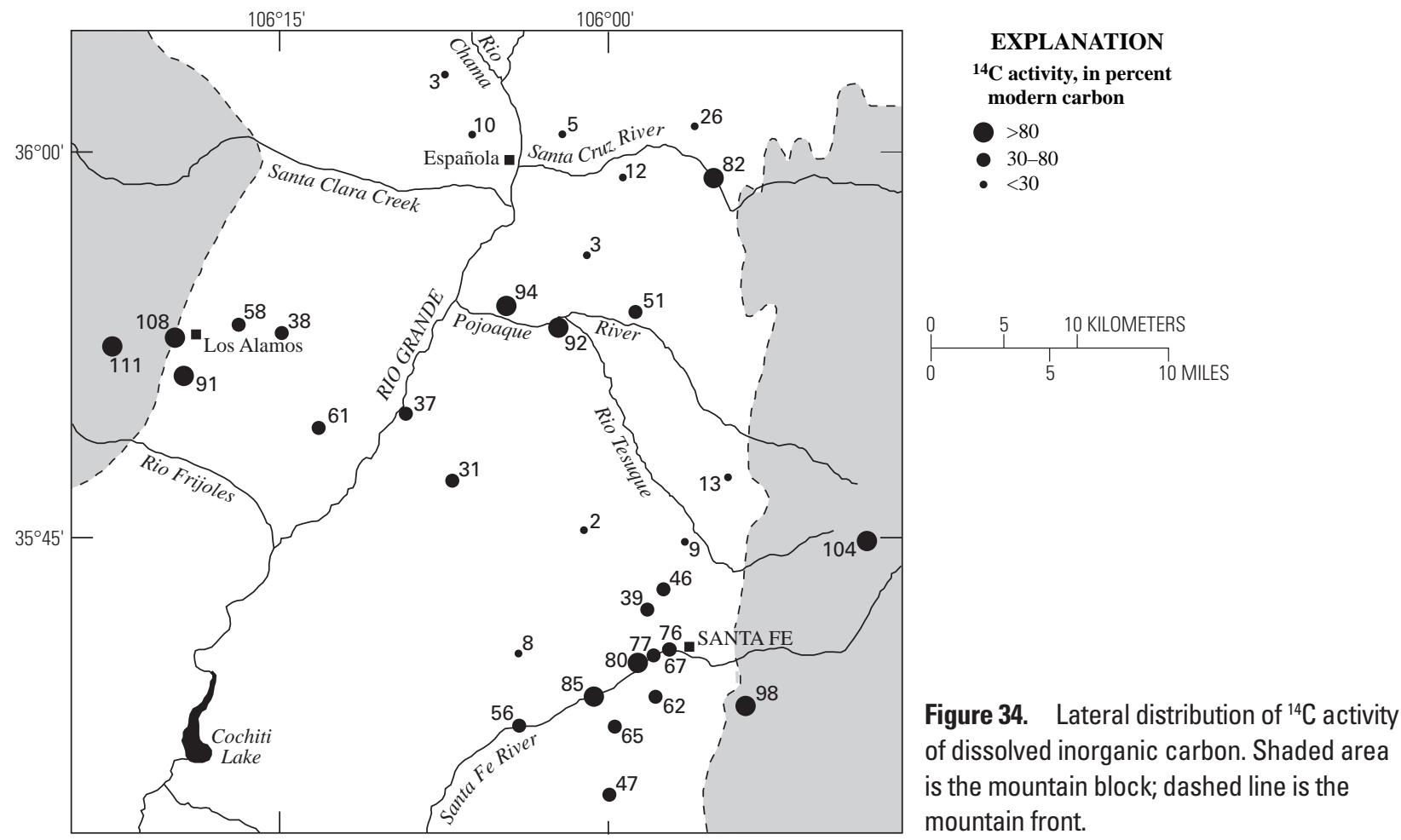
herein as "recharge waters" (table 8). Samples were considered recharge waters if they had a ${ }^{3} \mathrm{H}$ concentration $>1$ TU. These samples must contain a substantial fraction of "modern" water recharged after the early 1950s when open-air testing of nuclear bombs began and atmospheric ${ }^{3} \mathrm{H}$ concentrations increased dramatically. Sample WR4-01 is not considered a recharge water, despite having a ${ }^{3} \mathrm{H}$ concentration of $18.96 \mathrm{TU}$, because releases of wastewater containing very high ${ }^{3} \mathrm{H}$ concentrations (>10,000 TU) are known to have occurred at LANL (Longmire and others, 2007). This means that ${ }^{3} \mathrm{H}$ concentration $>1 \mathrm{TU}$ in

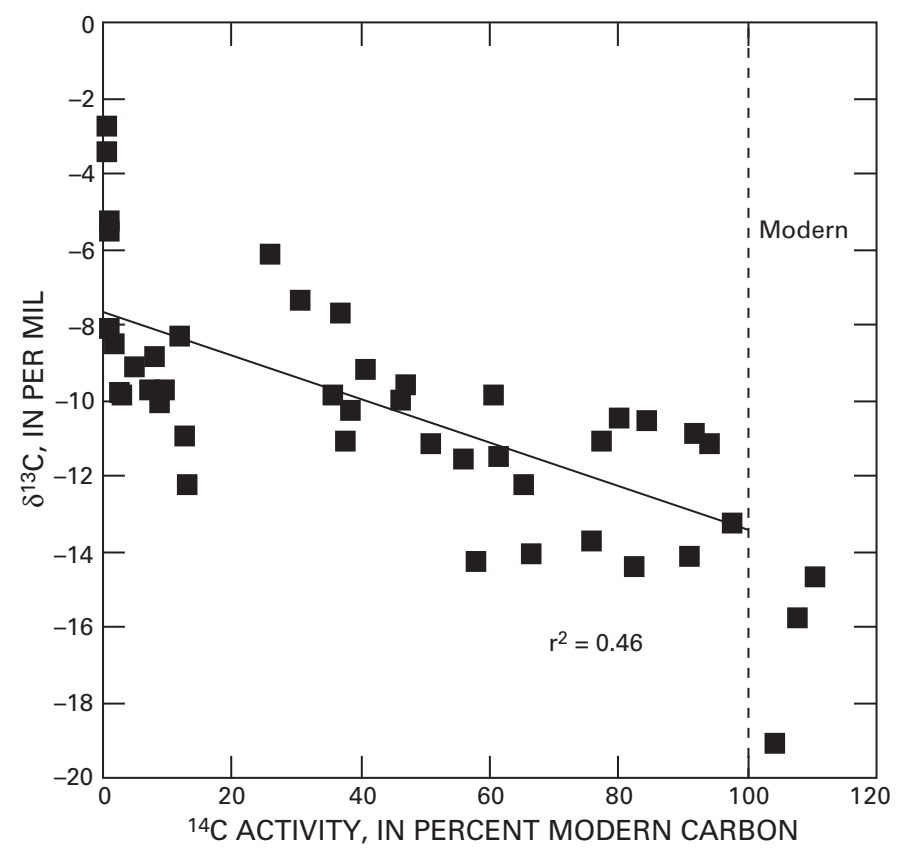

Figure 35. $\quad \delta^{13} \mathrm{C}$ versus ${ }^{14} \mathrm{C}$ activity of dissolved inorganic carbon.

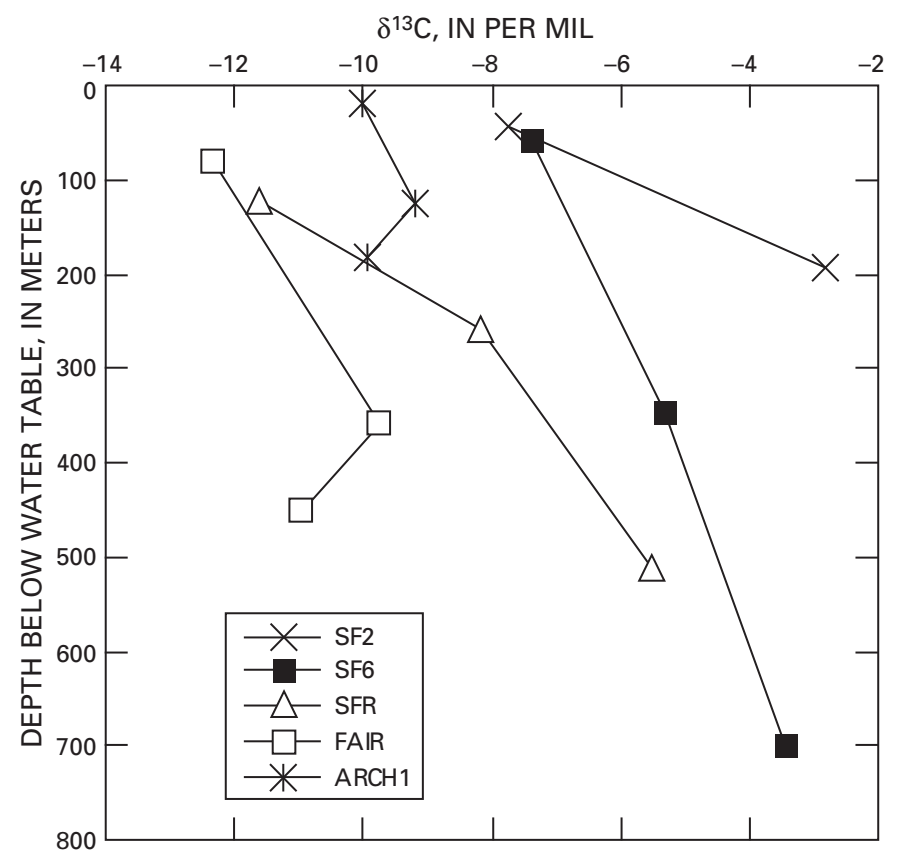

Figure 36. Vertical distribution of $\delta^{13} \mathrm{C}$ in nested piezometers. ground water below LANL could result from even very small fractions of modern water. Samples in table 8 were also collected from locations where young ground water is expected, including perched zones and shallow intervals in the regional aquifer in probable recharge areas (in the mountains, near the mountain front, and adjacent to rivers/streams that flow from the mountains to the Rio Grande). However, ${ }^{14} \mathrm{C}$ activities are also elevated in modern water due to open-air nuclear testing; the ${ }^{14} \mathrm{C}$ activity of atmospheric $\mathrm{CO}_{2}$ has averaged $120 \pm 10 \mathrm{pmC}$ for the past $20 \mathrm{yr}$ in the northern hemisphere. Consequently, the ${ }^{14} \mathrm{C}$ activity of DIC in recharge waters may not directly represent $\mathrm{A}_{0}$, because the DIC may have originated from atmospheric $\mathrm{CO}_{2}$ with a ${ }^{14} \mathrm{C}$ activity much greater than $100 \mathrm{pmC}$. A better approach, taken by Plummer and others (2004a), is to examine the range of ${ }^{14} \mathrm{C}$ activities of DIC in waters apparently containing very little modern water based on their low ${ }^{3} \mathrm{H}$ concentrations. The maximum end of this range should be equivalent to $\mathrm{A}_{0}$. Samples from the Española Basin with ${ }^{3} \mathrm{H}$ concentrations $<1 \mathrm{TU}$ (thus containing little modern water) have DIC ${ }^{14} \mathrm{C}$ activities ranging up to $91 \mathrm{pmC}$ (fig. 39). An $\mathrm{A}_{0}$ value of $90 \mathrm{pmC}$ is therefore considered to be the most likely for Española Basin waters.

Several models have been proposed for calculating $\mathrm{A}_{0}$ (for example, Mook, 1972; Fontes and Garnier, 1979). Applying these models requires knowing the ${ }^{13} \mathrm{C}$ and ${ }^{14} \mathrm{C}$ isotopic composition of the soil gas $\mathrm{CO}_{2}$ and carbonate minerals dissolving in the unsaturated zone. Insufficient carbon isotopic data are available for the Española Basin to allow for the reliable application of these models on a sample-by-sample basis. However, if reasonable ranges for unsaturated-zone carbon isotopic values are assumed, these models can be used to establish a range of expected $\mathrm{A}_{0}$ values, given the chemical and carbon isotopic

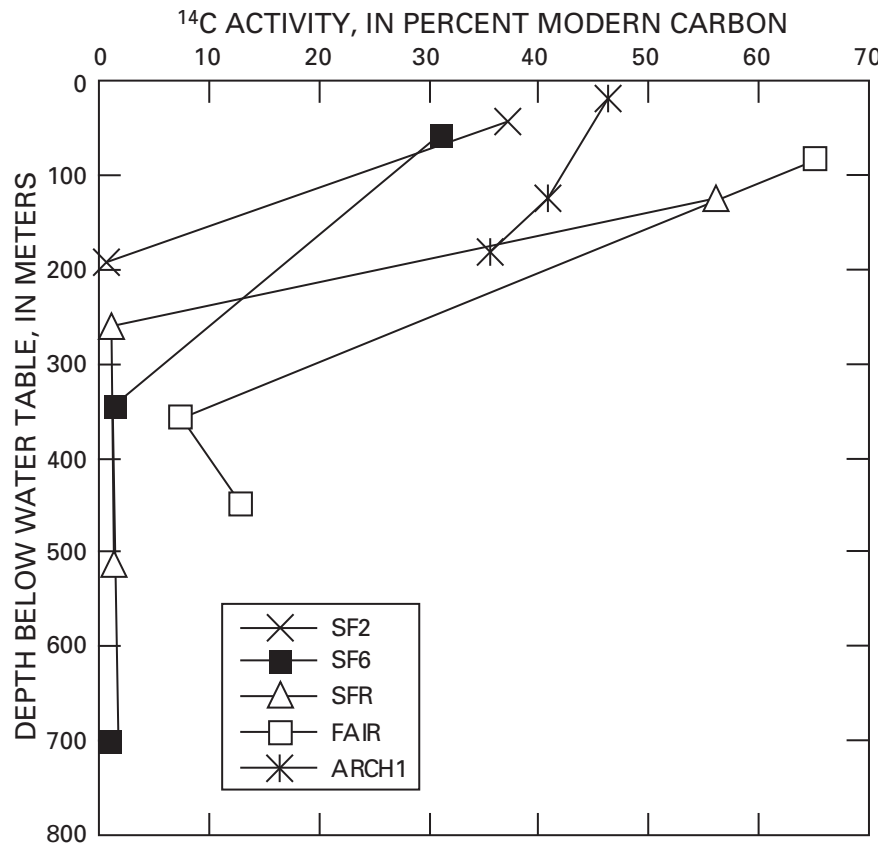

Figure 37. Vertical distribution of ${ }^{14} \mathrm{C}$ activity of dissolved inorganic carbon in nested piezometers. 


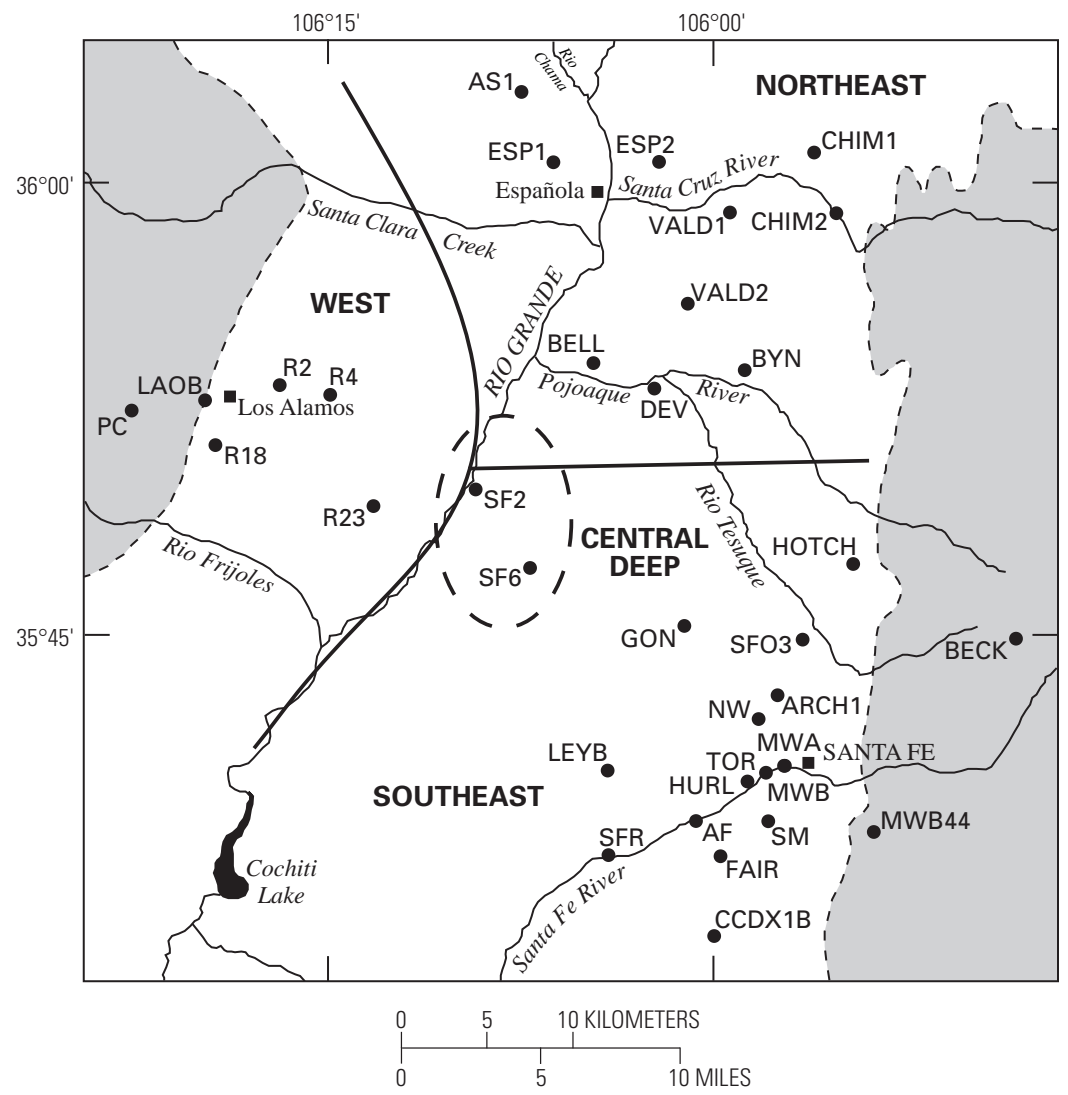

Figure 38. Hydrochemical zones.

Table 7. Median values of selected chemical and isotopic parameters by hydrochemical zone.

[DO, dissolved oxygen; SC, specific conductance; TDS, total dissolved solids; mS, microsiemens; pmC, parts modern carbon; U, undetermined; carbon isotopic values measured on dissolved inorganic carbon]

\begin{tabular}{|c|c|c|c|c|c|c|c|c|c|c|c|c|c|c|c|c|}
\hline $\begin{array}{l}\text { Hydro- } \\
\text { chemical } \\
\text { zone }\end{array}$ & \multicolumn{4}{|c|}{ Field parameters } & \multicolumn{2}{|c|}{ General chemistry } & \multicolumn{8}{|c|}{ Major ions } & \multicolumn{2}{|c|}{ Carbon isotopes } \\
\hline Southeast & 16.0 & 5.6 & 288.0 & 7.5 & 125.4 & 245.0 & 27.9 & 2.8 & 24.8 & 1.7 & 4.2 & 16.3 & 153.0 & 0.0 & -10.3 & 40.8 \\
\hline Northeast & 16.9 & 2.8 & 577.5 & 7.8 & 150.4 & 466.8 & 19.5 & 1.7 & 95.2 & 2.8 & 22.1 & 61.4 & 157.5 & 5.9 & -9.9 & 19.1 \\
\hline Central Deep & 20.7 & 0.2 & 1029.0 & 6.9 & 466.0 & 570.0 & 20.0 & 7.2 & 180.0 & 7.6 & 5.2 & 42.0 & 570.0 & $\mathrm{U}$ & -3.5 & 0.9 \\
\hline
\end{tabular}

composition of representative recharge waters. $\mathrm{A}_{0}$ values were computed using this approach for the recharge waters in table 8 applying the models of Vogel (1967), Tamers (1975), Ingerson and Pearson (1964), Mook (1972), Fontes and Garnier (1979), and Eichinger (1983). The following carbon isotopic values were assumed: $0-50 \mathrm{pmC}$ and -4 to $-6 \%$ for the ${ }^{14} \mathrm{C}$ activity and $\delta^{13} \mathrm{C}$, respectively, of unsaturated-zone carbonate minerals; $100 \mathrm{pmC}$ and -13 to $-22 \%$ for the ${ }^{14} \mathrm{C}$ activity and $\delta^{13} \mathrm{C}$, respectively, of the soil gas $\mathrm{CO}_{2}$. Assumed values are based on information in Kalin (2000), data from the MRGB in Plummer and others (2004a), and from unpublished data from the Española Basin collected by Edward Kwicklis and Brent Newman (Edward Kwicklis, Los Alamos National Laboratory, written commun., November 2006). The considerable majority of modeled $\mathrm{A}_{0}$ values were greater than approximately $70 \mathrm{pmC}$.
A minimum $\mathrm{A}_{0}$ of $70 \mathrm{pmC}$ was therefore assumed in this study. Observed DIC ${ }^{14} \mathrm{C}$ activities in recharge waters also generally exceed $70 \mathrm{pmC}$ (table 8), consistent with an assumed minimum $\mathrm{A}_{0}$ of $70 \mathrm{pmC}$.

\section{Geochemical Adjustments to Radiocarbon Ages}

Based on the chemical characteristics of ground water in the Española Basin discussed above, the ${ }^{14} \mathrm{C}$ activity of DIC in the samples collected for this study may have been affected by the following processes: (a) dissolution of calcite (in primary and secondary cement, caliche, and lithic fragments containing limestone); (b) precipitation of calcite; (c) carbon isotopic exchange with calcite; (d) Ca-Na cation exchange, which lowers the concentration of $\mathrm{Ca}$, allowing more calcite dissolution; 
Table 8. Recharge waters'1.

[zone, hydrochemical zone; TU, tritium units; pmC, percent modern carbon; $\mathrm{W}$, west; NE, northeast; SE, southeast]

\begin{tabular}{lcccr}
\hline $\begin{array}{c}\text { Sample } \\
\text { name }\end{array}$ & Zone & $\begin{array}{c}{ }^{3} \mathbf{H} \\
\text { (TU) }\end{array}$ & $\begin{array}{c}\delta^{\mathbf{1 3} \mathbf{C}} \text { (per mil) } \\
{ }^{14} \mathbf{C} \text { activity } \\
\text { (pmC) }\end{array}$ \\
\hline WPC-01 & $\mathrm{W}$ & 11.13 & -14.70 & 110.53 \\
WCAOB-01 & $\mathrm{W}$ & 17.37 & -15.82 & 107.90 \\
WDEV-01 & $\mathrm{NE}$ & 5.78 & -14.42 & 82.46 \\
WBYN-01 & $\mathrm{NE}$ & 7.92 & -10.90 & 91.94 \\
WBELL-01 & $\mathrm{NE}$ & 1.84 & -11.20 & 51.09 \\
BECK'S SPRING & $\mathrm{NE}$ & 3.89 & -11.22 & 94.44 \\
WMWB44-01 & $\mathrm{SE}$ & 8.83 & -19.10 & 104.34 \\
WMWA-01 & $\mathrm{SE}$ & 3.88 & -13.30 & 97.60 \\
WMWB-01 & $\mathrm{SE}$ & 5.98 & -13.76 & 75.91 \\
\hline
\end{tabular}

${ }^{1}$ Refers to ground water that has resided in the saturated zone for a relatively short time (hundreds of years or less).

(e) weathering of plagioclase feldspar, which increases the concentration of $\mathrm{Ca}$ and the $\mathrm{pH}$, both of which can inhibit calcite dissolution and/or cause calcite precipitation; (f) dissolution of gypsum, which increases the Ca concentration, having the same affect as weathering of plagioclase; (g) evapotranspiration, which also would inhibit calcite dissolution and/or cause calcite precipitation; and (h) mixing with a brine because the ${ }^{14} \mathrm{C}$ activity of DIC in a brine is probably near zero due to long residence times and extended interaction with marine carbonates at depth. Oxidation of dissolved organic carbon can also cause calcite dissolution by the addition of $\mathrm{CO}_{2}$. However, this process probably has little effect on DIC in the Española Basin because ground waters are generally aerobic, indicating low organic carbon content.

To account for these processes, geochemical mass-transfer models were constructed using the code NETPATH (Plummer and others, 1994). NETPATH determines all possible net geochemical reactions and associated mass transfer occurring along a flowpath between an initial and a final water composition, employing the equations of chemical mass balance, electron balance, and isotope mass balance. Carbon isotopic data were entered in NETPATH, allowing the code to compute a $\delta^{13} \mathrm{C}$ value and an "adjusted" radiocarbon age for the final water taking into account all mass tansfer and isotopic exchange involving C. Inputs to NETPATH and assumptions made in the development of the mass-transfer models are in the following discussion. The geochemical modeling was performed to investigate geochemical processes that potentially influence DIC (thus the radiocarbon age), and not to completely characterize all geochemical processes occurring in the aquifer. The central objectives of the geochemical modeling were to derive (1) a "preferred" (most likely) mass-transfer model and associated adjusted radiocarbon age, and (2) the range of possible radiocarbon age adjustments for each sample, and thereby determine the uncertainty of the radiocarbon age. Results of the geochemical modeling are presented in table 9.

\section{Source Waters and Mixing Models}

NETPATH requires the designation of an initial (source) water, or waters, that chemically evolve to become the final water (the sample of interest). For the Northeast and Southeast zones, two samples were selected that should represent the great majority of recharge to these zones: BECK'S SPRING and WCHIM2-01 (fig. 5, table 3). BECK'S SPRING is from a spring located in the Sangre de Cristo Mountains at an elevation of 3,168 masl. This sample should represent recharge high in the eastern mountain block that either becomes MBR or discharges to mountain streams, subsequently flowing to a lower elevation and infiltrating on the basin floor as stream loss. Sample WCHIM2-01 is from a shallow well adjacent to the Santa Cruz River at the mountain front and should represent recharge low in the eastern mountain block or at the eastern mountain front in the form of either MBR or stream loss. For the West zone, samples SPC-01 and WLAOB-01 were selected as source waters to represent most of the recharge (fig. 5, table 3). Sample SPC-01 is located at an elevation of 2,689 masl in the Jemez Mountains, and sample WLAOB-01 is located at the mountain front next to the stream bed in Los Alamos Canyon, which hosts seasonal stream flow. Samples SPC-01 and WLAOB-01 therefore should represent the same recharge components as BECK'S SPRING and WCHIM2-01, respectively, but for the west side of the basin.

Apparent $\mathrm{Cl}$ enrichment (fig. 20) suggests that many of the samples contain a small component of brine and/or human-impacted water, so samples were selected to represent these source waters as well. Saline2 and Robert's Geyser were selected to represent a brine (table 6), there being no

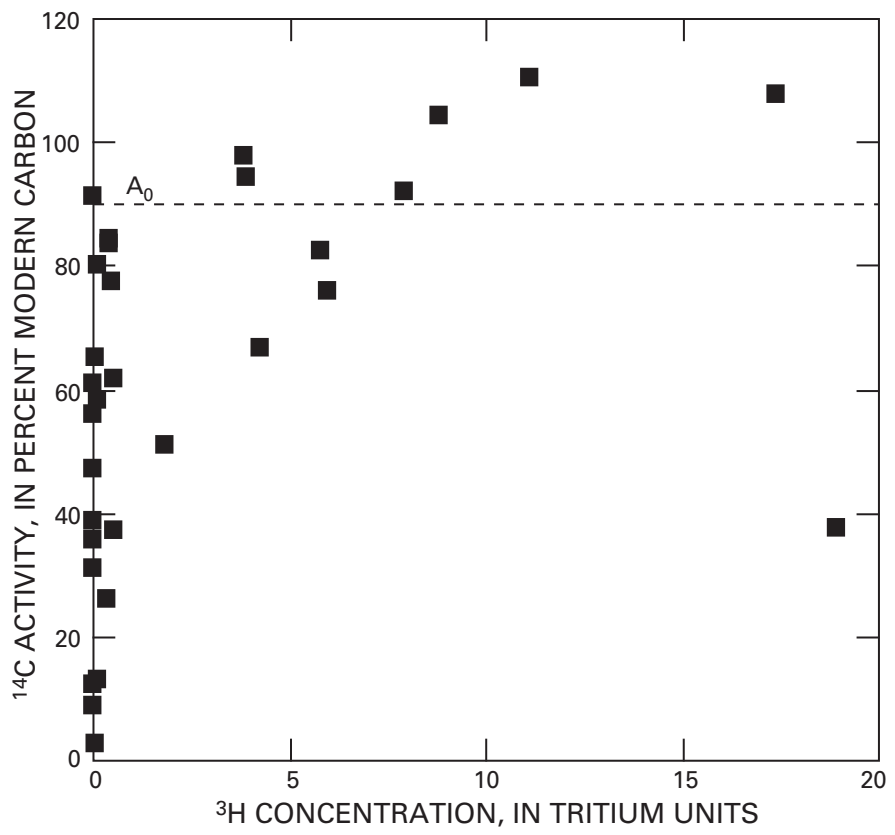

Figure $39 .{ }^{3} \mathrm{H}$ concentration versus ${ }^{14} \mathrm{C}$ activity of dissolved inorganic carbon. $A_{0^{\prime}}$ initial ${ }^{14} \mathrm{C}$ activity. 
solid justification for selecting one over the other. Sample WMWB-02 was selected to represent a human-impacted water (fig. 5, table 3). This sample has the highest concentrations of $\mathrm{Cl}$ and $\mathrm{NO}_{3}$ as $\mathrm{N}$ of the apparently human-impacted waters (by about a factor of 2, table 5), and it is screened in a perched aquifer near the Santa Fe River within the City of Santa Fe. Therefore, it probably contains the largest component of wastewater and/or surface runoff impacted by road salt.

Multiple source-water mixing models were considered in the geochemical modeling (table 10) representing all reasonable recharge pathways and mixing scenarios. NETPATH calculates mixing ratios and ET factors based on the $\mathrm{Cl}$ concentration of the source water(s) and final water. A sample's $\mathrm{Cl}$ concentration therefore determined which models were simulated for that sample. Mixing models 1-4 were simulated for Northeast, Southeast, and Central Deep zone samples with $\mathrm{Cl}$ concentrations $<15.0 \mathrm{mg} / \mathrm{L}$ (that of WCHIM2-01) and West zone samples with $\mathrm{Cl}$ concentrations $<16.0$ (that of WLAOB-01). Mixing models 5 and 6 were not simulated for these samples, because they can only produce final waters with $\mathrm{Cl}$ concentrations exceeding the sample concentration. Mixing models 3-6 were simulated for the remaining samples with higher $\mathrm{Cl}$ concentrations. Mixing model 1 was excluded for these higher $\mathrm{Cl}$ samples because nearly all have $\mathrm{Cl} / \mathrm{SO}_{4}$ ratios inconsistent with ET alone accounting for their $\mathrm{Cl}$ concentration (fig. 20). Mixing model 2 was excluded for these samples because it can only produce final waters with $\mathrm{Cl}$ concentrations below the sample concentration. Exceptions to the above rules include the following: (1) mixing models 4 and 6 were not simulated for samples collected from observation wells (short well screens and not pumped) screened at depths $>180 \mathrm{~m}$ below the water table because the likelihood of human-impacted water reaching these wells is very low; (2) mixing models $3 \mathrm{a}, 3 \mathrm{~b}, 5 \mathrm{a}$, and $5 \mathrm{~b}$ were not simulated for samples from observation wells screened at depths $<30 \mathrm{~m}$ below the water table, because the likelihood of a deep brine reaching these wells is very low; (3) West zone mixing models were simulated for samples WAS1-01 and WESP1-01 despite them belonging to the Northeast zone because wells AS1 and ESP1 are located on the west side of the Rio Grande, and are most likely recharged by the same source waters as samples in the West zone. Arguments perhaps could be made for reducing the number of simulated mixing models for more of the samples, based on the apparently low probability of a given model's applicability. However, this was not done in the interest of maintaining the robustness of the uncertainties in the adjusted ages derived in the geochemical modeling process.

\section{Phases and Constraints}

For Northeast, Southeast, and Central Deep zone samples, 7 phases were used including calcite, $\mathrm{CO}_{2}$ gas, $\mathrm{Ca}-\mathrm{Na}$ cation exchange, plagioclase $\left(\mathrm{An}_{38}\right.$, dissolution only), kaolinite (precipitation only), silica, and gypsum (dissolution only).
These phases were included because they are involved in the dominant geochemical processes controlling DIC. These are the same phases Plummer and others (2004a,b) included in their geochemical mass-transfer models computed with NETPATH to determine radiocarbon age adjustments for samples from the Santa Fe Group in the MRGB. The only difference was their inclusion of organic carbon; several of their samples (mostly from near the Rio Grande) had DO concentrations $<0.5 \mathrm{mg} / \mathrm{L}$. Phases used for the West zone samples were the same, except that gypsum was not included given the low likelihood of it occurring in the volcanic and volcaniclastic rocks of the West zone. For all the zones, 7 constraints were used, including $\mathrm{C}, \mathrm{Ca}, \mathrm{Na}, \mathrm{Cl}, \mathrm{S}, \mathrm{SiO}_{2}$, and $\mathrm{Al}$.

\section{Isotopic Composition of Carbon Sources}

For recharge source waters (represented by BECK'S SPRING, WCHIM2-01, SPC-01, and WLAOB-01), the ${ }^{14} \mathrm{C}$ activity $\left(\mathrm{A}_{0}\right)$ was assumed to be between 70 and $100 \mathrm{pmC}$, based on the above discussion regarding $\mathrm{A}_{0}$. Recharge source waters for Northeast, Southeast, and Central Deep zone samples were assumed to have a $\delta^{13} \mathrm{C}$ value of $-13 \%$, the mean for the recharge waters listed in table 8 located on the east side of the basin. Recharge source waters for West zone samples were assumed to have a $\delta^{13} \mathrm{C}$ value of $-15 \%$, the mean for the recharge waters in table 8 located on the west side of the basin. Measured ${ }^{14} \mathrm{C}$ activity and $\delta^{13} \mathrm{C}$ values in Saline 2 and Robert's Geyser were assumed for the brine source waters (table 6). Because the ${ }^{14} \mathrm{C}$ activity was not measured for Robert's Geyser, a value of 5 pmC was assumed, the same as Saline2. Measured ${ }^{14} \mathrm{C}$ activity and $\delta^{13} \mathrm{C}$ values in sample WMWB-02 were assumed for the human-impacted source water.

For Northeast, Southeast, and Central Deep zone samples, the ${ }^{14} \mathrm{C}$ activity and $\delta^{13} \mathrm{C}$ value of calcite was assumed to be $0 \mathrm{pmC}$ and $0 \%$, respectively, that of calcite in a marine carbonate. It is of course possible that the calcite has a higher ${ }^{14} \mathrm{C}$ activity and more negative $\delta^{13} \mathrm{C}$ value (if it were in calcite cement or caliche). However, a marine carbonate was assumed because it results in the largest age adjustments, maintaining the robustness of derived radiocarbon age uncertainties. If the modeled $\delta^{13} \mathrm{C}$ value was $>2 \%$ o heavier than the measured $\delta^{13} \mathrm{C}$ value (see following discussion of acceptance criteria for mass-transfer models), the ${ }^{14} \mathrm{C}$ activity and $\delta^{13} \mathrm{C}$ value of calcite was changed to $50 \mathrm{pmC}$ and $-5 \%$, respectively, that of calcite in the unsaturated zone (Kalin, 2000; Plummer and others, 2004a). This allowed the maximum number of mass-transfer models to be accepted, preventing the unjustified rejection of models potentially having large age adjustments. Note that this applies only to mixing models $1-4$, which could involve calcite dissolution in the unsaturated zone. For West zone samples, the $\delta^{13} \mathrm{C}$ value of calcite was assumed to be $-5 \%$. This lighter value is based on the low likelihood of lithic fragments that contain limestone occurring in the West zone, and on unpublished $\delta^{13} \mathrm{C}$ data from calcite cement and vein samples collected in the West zone 
Table 9. Unadjusted radiocarbon ages, preferred geochemical mass-transfer models, and adjusted radiocarbon ages.

[pmC, parts modern carbon]

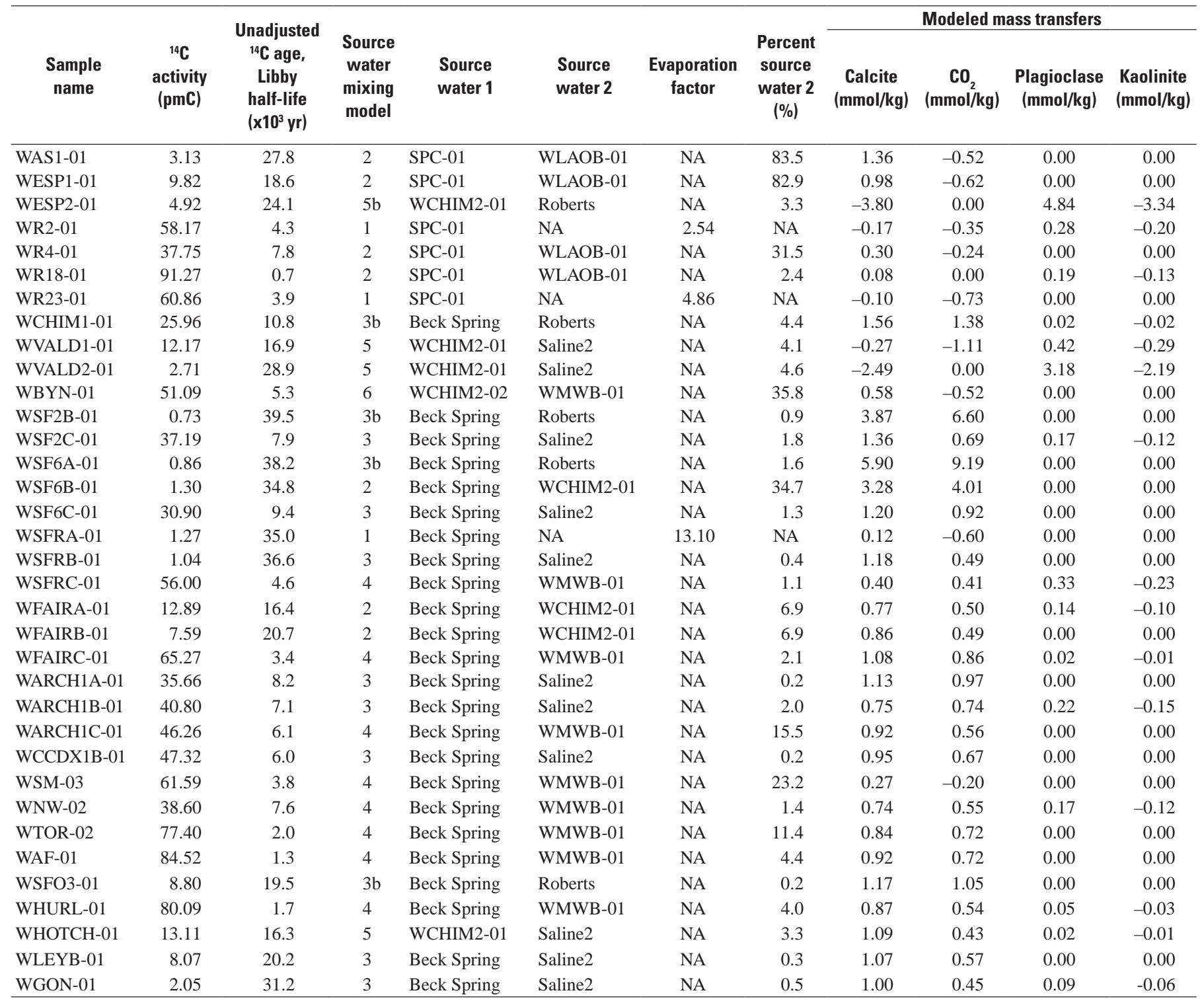

${ }^{1}$ Unadjusted ${ }^{14} \mathrm{C}$ age (Libby half-life) minus preferred adjusted ${ }^{14} \mathrm{C}$ age (Libby half-life).

(Edward Kwicklis, Los Alamos National Laboratory, written commun., November 2006). The ${ }^{14} \mathrm{C}$ activity for calcite for West zone samples was assumed to be $0 \mathrm{pmC}$ in the absence of any available data.

For all samples, a ${ }^{14} \mathrm{C}$ activity and $\delta^{13} \mathrm{C}$ value of $100 \mathrm{pmC}$ and $-20 \%$, respectively, were assumed for $\mathrm{CO}_{2}$ gas. This is near the low end of the range of $\delta^{13} \mathrm{C}$ values measured on soil-gas samples in the MRGB by Plummer and others (2004a). A minimum (light) $\delta^{13} \mathrm{C}$ value was assumed because assuming a heavier value results in heavier modeled $\delta^{13} \mathrm{C}$ values, leading to the rejection of more mass-transfer models (see following discussion of acceptance criteria for mass-transfer models). This can lead to the unjustified rejection of models potentially having large age adjustments.

\section{Mass-Transfer Models}

Multiple mixing models were simulated for each sample and NETPATH-generated multiple mass-transfer models for each mixing model, resulting in a total of approximately 800 mass-transfer models. These mass-transfer models were accepted or rejected based on the modeled $\delta^{13} \mathrm{C}$ value, using the following criteria. Models computing $\delta^{13} \mathrm{C}$ values $>2 \%$ o heavier (more positive) than the measured $\delta^{13} \mathrm{C}$ value were rejected. Aside from improbable mass transfers, potential reasons for an overly heavy modeled $\delta^{13} \mathrm{C}$ value include an erroneously heavy assumed $\delta^{13} \mathrm{C}$ value for $\mathrm{CO}_{2}$ gas, calcite, or source water(s). The first scenario can be ruled out because a low-end $\delta^{13} \mathrm{C}$ value for $\mathrm{CO}_{2}$ gas $(-20 \%$ ) was assumed. The second scenario was addressed by changing the calcite $\delta^{13} \mathrm{C}$ value to a low-end value 
Table 9. Unadjusted radiocarbon ages, preferred geochemical mass-transfer models, and adjusted radiocarbon ages. - Continued

[pmC, parts modern carbon]

\begin{tabular}{|c|c|c|c|c|c|c|c|c|c|c|c|c|c|}
\hline \multirow[b]{2}{*}{$\begin{array}{c}\text { Sample } \\
\text { name }\end{array}$} & \multicolumn{3}{|c|}{ Modeled mass transfers } & \multirow[b]{2}{*}{$\begin{array}{c}\text { Modeled } \\
\delta^{13} \mathrm{C} \\
\text { (per mil) }\end{array}$} & \multirow[b]{2}{*}{$\begin{array}{c}\text { Measured } \\
\delta^{13} \mathrm{C} \\
\text { (per mil) }\end{array}$} & \multirow{2}{*}{$\begin{array}{c}\text { Preferred } \\
\text { adjusted } \\
{ }^{14} \mathrm{C} \text { age, } \\
\text { Libby } \\
\text { half-life } \\
\left(\mathbf{x} 10^{3} \mathrm{yr}\right) \\
\end{array}$} & \multirow{2}{*}{$\begin{array}{c}\text { Minimum } \\
\text { adjusted } \\
{ }^{14} \mathrm{C} \text { age, } \\
\text { Libby } \\
\text { half-life } \\
\left(\mathbf{x} 10^{3} \mathrm{yr}\right)\end{array}$} & \multirow{2}{*}{$\begin{array}{c}\text { Maximum } \\
\text { adjusted } \\
{ }^{14} \mathrm{C} \text { age, } \\
\text { Libby } \\
\text { half-life } \\
\left(\mathrm{x} 10^{3} \mathrm{yr}\right)\end{array}$} & \multirow[b]{2}{*}{$\begin{array}{l}{ }^{14} \mathrm{C} \text { age } \\
\text { adjust- } \\
\text { ment }{ }^{1} \\
\left(\times 10^{3} \mathrm{yr}\right)\end{array}$} & \multirow[b]{2}{*}{$\begin{array}{l}\text { Unadjusted } \\
{ }^{14} \mathrm{C} \text { age, } \\
\text { calendar } \\
\text { years } \\
\left(\mathrm{x} 10^{3} \mathrm{yr}\right)\end{array}$} & \multirow{2}{*}{$\begin{array}{l}\text { Preferred } \\
\text { adjusted } \\
{ }^{14} \mathrm{C} \text { age, } \\
\text { calendar } \\
\text { years } \\
\left(\times 10^{3} \mathrm{yr}\right)\end{array}$} & \multirow{2}{*}{$\begin{array}{c}\text { Min } \\
\text { adjusted } \\
{ }^{14} \mathrm{C} \text { age, } \\
\text { calendar } \\
\text { years } \\
\left(\mathrm{x} 10^{3} \mathrm{yr}\right)\end{array}$} & \multirow{2}{*}{$\begin{array}{c}\text { Max } \\
\text { adjusted } \\
{ }^{14} \mathrm{C} \text { age, } \\
\text { calendar } \\
\text { years } \\
\left(\times 10^{3} \mathrm{yr}\right)\end{array}$} \\
\hline & $\begin{array}{c}\mathrm{SiO}_{2} \\
(\mathrm{mmol} / \mathrm{kg})\end{array}$ & $\begin{array}{c}\text { Ca-Na } \\
\text { cation } \\
\text { exchange } \\
\text { (mmol/kg) }\end{array}$ & $\begin{array}{c}\text { Gypsum } \\
\text { (mmol/kg) }\end{array}$ & & & & & & & & & & \\
\hline WAS1-01 & -0.13 & 1.75 & NA & -9.44 & -9.95 & 24.0 & 21.3 & 27.8 & 3.7 & 30.0 & 27.2 & 24.6 & 30.5 \\
\hline WESP1-01 & -0.21 & 1.19 & NA & -9.59 & -9.76 & 15.5 & 13.0 & 17.8 & 3.0 & 22.1 & 18.8 & 15.3 & 21.1 \\
\hline WESP2-01 & -6.00 & -0.88 & 0.24 & -7.99 & -9.14 & 18.4 & 18.4 & 23.6 & 5.7 & 27.3 & 21.9 & 21.9 & 26.9 \\
\hline WR4-01 & 0.62 & -0.12 & NA & -12.11 & -11.10 & 7.3 & 5.2 & 8.0 & 0.5 & 8.6 & 8.1 & 6.0 & 8.8 \\
\hline WR18-01 & 0.13 & 0.06 & NA & -14.35 & -14.20 & 0.2 & 0.0 & 0.8 & 0.5 & 0.7 & 0.2 & 0.0 & 0.7 \\
\hline WR23-01 & -0.39 & -0.03 & NA & -8.30 & -9.90 & 4.2 & 0.2 & 4.2 & -0.3 & 4.4 & 4.7 & 0.2 & 4.7 \\
\hline WCHIM1-01 & 0.00 & 1.84 & 0.55 & -4.91 & -6.17 & 0.7 & 0.6 & 9.2 & 10.1 & 12.8 & 0.7 & 0.6 & 10.4 \\
\hline WVALD1-01 & 0.00 & 0.90 & 0.55 & -6.93 & -8.33 & 13.8 & 9.7 & 17.0 & 3.1 & 20.0 & 16.4 & 11.0 & 20.1 \\
\hline WVALD2-01 & -3.92 & 1.31 & 2.03 & -10.11 & -9.82 & 25.8 & 25.8 & 28.6 & 3.1 & 31.4 & 28.8 & 28.8 & 31.1 \\
\hline WSF6C-01 & 0.19 & 0.83 & 0.15 & -8.71 & -7.38 & 4.0 & 2.8 & 9.2 & 5.4 & 10.6 & 4.4 & 2.9 & 10.4 \\
\hline WSFRA-01 & -0.18 & 0.16 & -0.02 & -5.72 & -5.53 & 33.6 & 27.2 & 35.5 & 1.4 & 36.8 & 35.4 & 29.9 & 37.3 \\
\hline WSFRB-01 & 0.14 & 1.15 & 0.16 & -7.87 & -8.16 & 31.6 & 30.6 & 37.2 & 5.0 & 38.4 & 33.7 & 32.8 & 39.0 \\
\hline WSFRC-01 & -0.27 & 0.00 & -0.01 & -11.70 & -11.60 & 1.9 & 0.4 & 4.2 & 2.7 & 5.3 & 1.8 & 0.4 & 4.7 \\
\hline WFAIRA-01 & 0.00 & 0.45 & 0.04 & -10.14 & -10.96 & 13.0 & 11.0 & 16.3 & 3.4 & 19.6 & 15.3 & 13.0 & 19.5 \\
\hline WFAIRB-01 & 0.19 & 0.38 & 0.06 & -9.73 & -9.74 & 17.0 & 15.7 & 20.7 & 3.6 & 24.0 & 20.1 & 19.0 & 24.1 \\
\hline WFAIRC-01 & 0.00 & 0.49 & 0.02 & -12.16 & -12.30 & 1.4 & 0.0 & 2.9 & 2.0 & 3.6 & 1.3 & 0.0 & 3.1 \\
\hline WARCH1A-01 & 0.21 & 0.40 & 0.06 & -10.13 & -9.92 & 4.0 & 3.5 & 7.1 & 4.2 & 9.2 & 4.5 & 3.8 & 7.9 \\
\hline WARCH1B-01 & -0.07 & 0.00 & 0.02 & -8.70 & -9.19 & 1.8 & 1.0 & 6.2 & 5.3 & 8.0 & 1.8 & 0.9 & 7.2 \\
\hline WARCH1C-01 & 0.12 & 1.10 & 0.13 & -10.95 & -10.00 & 2.0 & 1.4 & 3.8 & 4.1 & 7.0 & 2.0 & 1.3 & 4.1 \\
\hline WCCDX1B-01 & 0.13 & 0.18 & 0.03 & -9.63 & -9.60 & 1.5 & 0.8 & 5.6 & 4.5 & 6.8 & 1.4 & 0.7 & 6.4 \\
\hline WGON-01 & 0.00 & 0.82 & 0.16 & -8.20 & -8.51 & 26.4 & 26.0 & 31.6 & 4.8 & 33.3 & 29.3 & 28.9 & 33.7 \\
\hline
\end{tabular}

of $-5 \%$ o (if not already) and recomputing the sample $\delta^{13} \mathrm{C}$ value. If the new modeled $\delta^{13} \mathrm{C}$ value was $<2 \%$ heavier than the measured value, the mass-transfer model was accepted. The third scenario is unlikely given that only one of the recharge waters listed in table 8 has a $\delta^{13} \mathrm{C}$ value $>2 \%$ lighter than the mean value for recharge waters on the same side of the basin $(-15 \%$ o on the west side and $-13 \%$ on the east side). Further, brine source waters are unlikely to have $\delta^{13} \mathrm{C}$ values $>2 \%$ lighter than Saline2 and Robert's Geyser (both about $-0.5 \%$ ) because of their likely prolonged contact with Paleozoic carbonates having $\delta^{13} \mathrm{C}$ values near $0 \%$.

Mass-transfer models computing $\delta^{13} \mathrm{C}$ values lighter (more negative) than the assumed recharge source water $(-13 \%$ or $-15 \%$ o) were rejected. However, if the sample $\delta^{13} \mathrm{C}$ value was within $2 \%$ of the assumed recharge source water, only models with computed $\delta^{13} \mathrm{C}$ values $>2 \%$ lighter than the sample were rejected. These criteria for the rejection of models with overly light $\delta^{13} \mathrm{C}$ values are more liberal than the criteria for the rejection of models with overly heavy $\delta^{13} \mathrm{C}$ values, often allowing modeled $\delta^{13} \mathrm{C}$ values several per mil lighter than measured values. The reason is that it is possible that $\delta^{13} \mathrm{C}$ values of recharge source waters have decreased in the past several hundred years by perhaps as much as $2-4 \%$ o due to changes in the relative abundance of $\mathrm{C}_{3}$ versus $\mathrm{C}_{4}$ plants in recharge areas (Plummer and others, 2004a). Aside from improbable mass transfers, potential reasons for an overly light modeled $\delta^{13} \mathrm{C}$ value include an erroneously light assumed $\delta^{13} \mathrm{C}$ value for calcite, source water(s), or $\mathrm{CO}_{2}$ gas. The first scenario can be ruled out because calcite $\delta^{13} \mathrm{C}$ values $>2 \%$ for marine carbonates and $>-3 \%$ o for cements and caliche are unlikely. 
Table 10. Mixing models used in geochemical modeling.

[ET, Evapotranspiration; $\mathrm{Y}$, yes; $\mathrm{N}, \mathrm{no}]$

\begin{tabular}{clll}
\hline $\begin{array}{c}\text { Mixing } \\
\text { model } \\
\text { number }\end{array}$ & \multicolumn{1}{c}{$\begin{array}{c}\text { Source } \\
\text { water 1 }\end{array}$} & \multicolumn{1}{c}{$\begin{array}{c}\text { Source } \\
\text { water } 2\end{array}$} & ET \\
\hline \multicolumn{2}{c}{} & Northeast, Southeast, and Central Deep zones & \\
\hline 1 & Beck Spring & NA & Y \\
2 & Beck Spring & WCHIM2-01 & N \\
$3 \mathrm{a}$ & Beck Spring & Saline2 & $\mathrm{N}$ \\
$3 \mathrm{~b}$ & Beck Spring & Roberts & $\mathrm{N}$ \\
4 & Beck Spring & WMWB-02 & $\mathrm{N}$ \\
$5 \mathrm{a}$ & WCHIM2-01 & Saline2 & $\mathrm{N}$ \\
$5 \mathrm{~b}$ & WCHIM2-01 & Roberts & $\mathrm{N}$ \\
6 & WCHIM2-01 & WMWB-01 & $\mathrm{N}$ \\
\hline & & West zone & $\mathrm{Y}$ \\
\hline 1 & SPC-01 & NA & $\mathrm{N}$ \\
2 & SPC-01 & WLAOB-01 & $\mathrm{N}$ \\
$3 \mathrm{a}$ & SPC-01 & Saline2 & $\mathrm{N}$ \\
$3 \mathrm{~b}$ & SPC-01 & Roberts & $\mathrm{N}$ \\
4 & SPC-01 & WMWB-02 & $\mathrm{N}$ \\
$5 \mathrm{a}$ & WLAOB-01 & Saline2 & $\mathrm{N}$ \\
$5 \mathrm{~b}$ & WLAOB-01 & Roberts & $\mathrm{N}$ \\
6 & WLAOB-01 & WMWB-01 & \\
\hline
\end{tabular}

The second scenario is unlikely given that none of the recharge waters listed in table 8 has a $\delta^{13} \mathrm{C}$ value $>2 \%$ heavier than the mean value for recharge waters located on the same side of the basin. The third scenario is a possibility. However, the effort was not expended to re-compute modeled $\delta^{13} \mathrm{C}$ values using a heavier assumed $\delta^{13} \mathrm{C}$ value for $\mathrm{CO}_{2}$ gas, because mass-transfer models rejected using this criterion uniformly had very small age adjustments, meaning that their acceptance/rejection has little influence on the derived range of possible ages.

For each sample, the acceptable mass-transfer model with the computed $\delta^{13} \mathrm{C}$ value closest to the measured $\delta^{13} \mathrm{C}$ value was selected as the "preferred" mass-transfer model, having the "preferred" adjusted radiocarbon age (table 9). In the few cases where two mass-transfer models were nearly equal candidates for the preferred model, other factors were considered, primarily the likelihood of different mixing models given a well's position in the flow system. For each sample, the smallest and largest adjusted ages among the group of acceptable mass-transfer models were selected as the minimum and maximum adjusted ages, respectively (table 9). Unadjusted and adjusted ${ }^{14} \mathrm{C}$ ages were initially calculated using the Libby half-life $(5,568 \mathrm{yr})$ instead of the modern half-life $(5,730 \mathrm{yr})$ to enable the use of radiocarbon calibration scales. These calibration scales take into account variations in the ${ }^{14} \mathrm{C}$ activity of atmospheric $\mathrm{CO}_{2}$ in the past (see Plummer and others, 2004a). The unadjusted and adjusted ${ }^{14} \mathrm{C}$ ages computed with the Libby half-life were converted to calendar years before present (before 1950) using radiocarbon calibration scales presented by Stuiver and others (1998) (table 9). Henceforth, the "unadjusted age" refers to the unadjusted age computed using the Libby half-life, and the "adjusted age" refers to the preferred adjusted age in calendar years. The "minimum age" is considered to be the minimum adjusted age in calendar years. The "maximum age" is considered to be the maximum adjusted age in calendar years or the unadjusted age in calendar years, whichever is larger. Given the broad range of possible geochemical and isotopic scenarios considered in the mass-transfer modeling, the minimum and maximum ages should represent a reliable (and probably overly conservative) expression of the uncertainty in the radiocarbon age. A specific probability cannot be assigned to the limits of the range of possible ages (for example, $1-\sigma$ error), because the error distribution is unknown and a formal error analysis was not performed. However, the probability of the true age falling within the range of uncertainty is probably closer to 90 percent (as with a 2- $\sigma$ error) than 70 percent (as with a 1- $\sigma$ error), given the conservative assumptions made in the mass-transfer modeling. Analytical uncertainty in the ${ }^{14} \mathrm{C}$ activity was not accounted for, but this potential error is relatively small (generally $<10$ percent) in comparison to the potential error associated with uncertainty in the age adjustment.

In most cases, phases with the largest mass transfers are calcite, $\mathrm{CO}_{2}$ gas, and $\mathrm{Ca}-\mathrm{Na}$ cation exchange. Mass transfers generally are about $1 \mathrm{mmol} / \mathrm{kg} \mathrm{H}_{2} \mathrm{O}$ or less. Samples WESP2-01, WVAL1-01, and WVALD2-01 in the Northeast zone are exceptions - these having considerable plagioclase dissolution $(0.4-4.8 \mathrm{mmol} / \mathrm{kg})$. These samples are from neighboring wells east of the Rio Grande and have the oldest unadjusted radiocarbon ages in the Northeast zone.

Many of the samples have $\mathrm{CO}_{2}$ gas mass transfers of $0.4-1.0 \mathrm{mmol} / \mathrm{kg}$, apparently demanding a subsurface source of $\mathrm{CO}_{2}$. All of these samples have preferred source-water mixing model numbers 1-4 (table 9), which include a source water (BECK'S SPRING or SPC-01) that may have reinfiltrated through the unsaturated zone as stream loss. A likely source of $\mathrm{CO}_{2}$ for these samples is therefore $\mathrm{CO}_{2}$ in soil gas in the unsaturated zone. A dissolved concentration of $1 \mathrm{mmol} / \mathrm{kg}$ of $\mathrm{CO}_{2}$ gas would require an unsaturated-zone $\mathrm{CO}_{2}$-gas partial pressure of approximately $0.02 \mathrm{~atm}$. This is within the range, but near the high end, of soil gas $\mathrm{CO}_{2}$ concentrations measured in the MRGB (Plummer and others, 2004a) and commonly observed in other locations (Richardson and McSween, 1989, p. 185-187).

Samples from the Central Deep zone have $\mathrm{CO}_{2}$ gas mass transfers well above $1 \mathrm{mmol} / \mathrm{kg}$ ( $4-9 \mathrm{mmol} / \mathrm{kg}$ ). Anomalously high $\mathrm{CO}_{2}$ gas mass transfers can be due to large charge imbalances (the "charge balance" option was used in NETPATH) or due to the selection of inappropriate source waters. These factors may partly explain why some of the samples have $\mathrm{CO}_{2}$ gas mass transfers near the high end of the expected range (near $1 \mathrm{mmol} / \mathrm{kg}$ ). However, they probably do not explain the very high $\mathrm{CO}_{2}$ gas mass transfers for the Central Deep zone samples because the charge imbalance for these samples is not unusually large (absolute value $<2.3$ percent, table 3 ), and there is little reason to think that the Central Deep zone 
samples originated from substantially different source waters than the rest of the samples in the data set. A more likely explanation is that the Central Deep zone samples interacted with a different subsurface source of $\mathrm{CO}_{2}$. This possibility is supported by the fact that Central Deep zone samples were the only ones having no mass-transfer models with computed $\delta^{13} \mathrm{C}$ values within $2 \%$ of the measured value (all computed values were too light) using the assumed carbon isotopic values described previously. One possible source is mantlederived $\mathrm{CO}_{2}$ that has ascended deep rift-zone faults. At depth under high hydrostatic pressure, ground water that encounters this mantle-derived $\mathrm{CO}_{2}$ could acquire dissolved $\mathrm{CO}_{2}$ concentrations well above $1 \mathrm{mmol} / \mathrm{kg}$. Cumming (1997) measured a $\mathrm{CO}_{2}$ partial pressure of 1.03 atm in Robert's Geyser, with a $\delta^{13} \mathrm{C}$ value of $-7.11 \%$. Cumming (1997) also presents several arguments supporting a mantle origin for this $\mathrm{CO}_{2}$ gas as opposed to a biogenic or marine carbonate origin. The ${ }^{3} \mathrm{He} /{ }^{4} \mathrm{He}$ ratio of the terrigenic $\mathrm{He}$ component in samples from SF2 and SF6 (see following section entitled "Mantle Helium") are also well above 0.3 (1.5 to 2.0), consistent with Central Deep zone samples mixing with a deep mantle-fluid phase. Mass-transfer models were therefore computed for the Central Deep zone samples assuming a ${ }^{14} \mathrm{C}$ activity and $\delta^{13} \mathrm{C}$ value of $0 \mathrm{pmC}$ and $-7 \%$, respectively, for $\mathrm{CO}_{2}$ gas. This adjustment resulted in modeled $\delta^{13} \mathrm{C}$ values considerably closer to measured values.

Only three of the preferred mass-transfer models include ET, these having ET factors of 2.5-13.1. The remainder include mixing between two source waters. In mixtures including a brine, the brine composes up to 5 percent, and in mixtures including a human-impacted water, the human-impacted water composes up to 36 percent. Figure 40 shows the distribution of the type of source-water mixing model associated with the preferred mass-transfer model. For samples collected west of the Rio Grande, preferred mass-transfer models include either ET or mixing between recharge source waters (SPC-01 or WLAOB-01) only. For Northeast zone samples, 4 of 5 preferred mass-transfer models include mixing between a recharge source water (BECK'S SPRING or WCHIM2-01) and a brine, further supporting the widespread influence of upward leaking brines in the Northeast zone. For Southeast zone samples, preferred mass-transfer models primarily include mixing between a recharge source water (BECK'S SPRING or WCHIM2-01) and either a brine or a human-impacted water. Those samples with mass-transfer models including mixing with human-impacted water all were collected in the vicinity of Santa Fe, consistent with ground water in the Santa Fe area being widely impacted by human activity. In general, samples with mass-transfer models including brine mixing have older radiocarbon ages, and samples with mass-transfer models including mixing with a human-impacted water have younger radiocarbon ages, as expected (table 9).

\section{Unadjusted and Adjusted Radiocarbon Ages}

Unadjusted ${ }^{14} \mathrm{C}$ ages range from 0 to $39,500 \mathrm{yr}$. The horizontal distribution of unadjusted ages shows an overall pattern of increasing age with distance from the mountain front and from rivers other than the Rio Grande (fig. 41), consistent

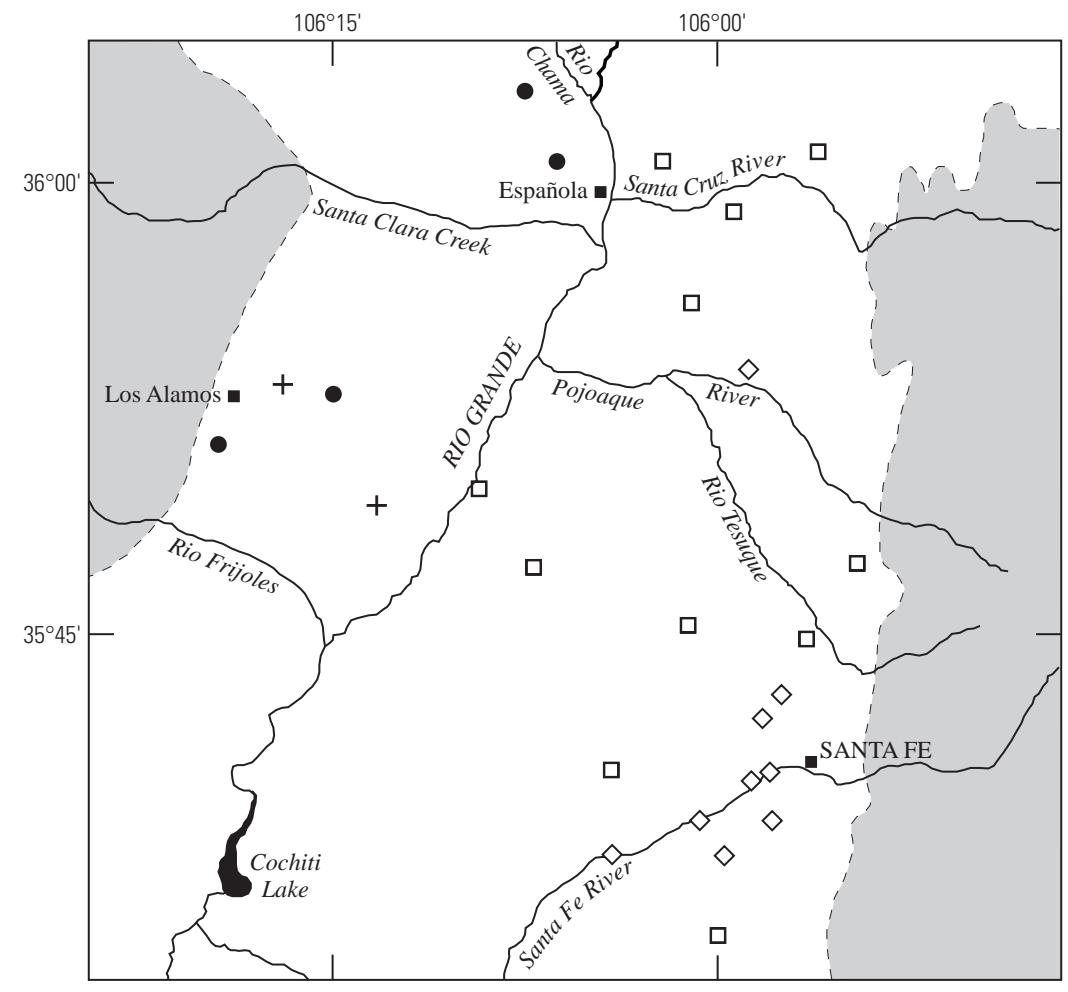

\section{EXPLANATION}

Mixing model type

+ Recharge water and evapotranspiration

Recharge waters only

$\square$ Brine mix

$\diamond$ Human-impacted mix

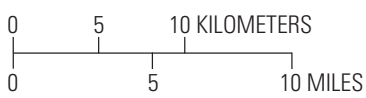

Figure 40. Lateral distribution of mixing model type. Shaded area is the mountain block; dashed line is the mountain front. 
with the occurrence of both MBR and stream loss. However, samples WBELL-01 and WDEV-01 in the lower Pojoaque River drainage, samples WSF6C-01 and WSF2C-01 in the lower Cañada Ancha arroyo, and sample WR23 in the eastern part of the West zone all have unadjusted ages younger than samples collected from up-gradient wells located closer to the mountain front. This pattern suggests that recharge, probably in the form of stream loss and infiltration along arroyos, is not just occurring near the mountain front, but may also occur well out into the basin in some areas. Unadjusted ages of the nested piezometer samples generally increase with depth (fig. 42), as expected. An abrupt transition is apparent at a depth of about $200 \mathrm{~m}$ below the water table; samples above this depth have unadjusted ages $<10,000 \mathrm{yr}$, and samples below this depth have unadjusted ages dominantly $>20,000$. This age transition suggests that ground-water flow rates decrease considerably at a depth of about $200 \mathrm{~m}$ below the water table, perhaps associated with a marked decrease in permeability at this depth. This is consistent with the temperature profiles, which indicate little vertical ground-water flow below about $250 \mathrm{~m}$ below ground surface (bgs) (fig. 6).

The "age adjustment" is the unadjusted age (Libby half-life) minus the preferred adjusted age (Libby half-life) (table 9). Age adjustments are generally $<6,000 \mathrm{yr}$, and they are positive (adjusted ages younger than unadjusted ages) for all samples but two. Samples with larger age adjustments generally have preferred mass-transfer models with larger calcite mass transfers and larger percentages of a brine source water, both sources of carbon with a low ${ }^{14} \mathrm{C}$ activity. Samples from the Central Deep zone have age adjustments considerably larger than samples from the other zones $(13,300-24,000 \mathrm{yr})$. In addition to having the largest calcite mass transfers, more $\mathrm{CO}_{2}$ has dissolved into these samples than the others, and the source of this $\mathrm{CO}_{2}$ is assumed to be mantle $\mathrm{CO}_{2}$ with a ${ }^{14} \mathrm{C}$ activity of $0 \mathrm{pmC}$. West zone samples have the smallest age adjustments $(<500 \mathrm{yr})$ due to their low calcite mass transfers and lack of a brine source water, and the only two samples with negative age adjustments (WR2-01 and WR23-01) are located in the West zone.

Adjusted ages range from 0 to $35,400 \mathrm{yr}$. Because most age adjustments are of a similar magnitude $(1,000-5,000 \mathrm{yr})$, adjusted ages maintain the same general trends in their spatial distribution as the unadjusted ages (figs. 43 and 44). Adjusted ages were not calculated for the recharge waters listed in table 8; the age of these samples clearly being hundreds of years or less. Recharge waters were assigned an adjusted age of $0 \mathrm{yr}$ in figure 43 and subsequent figures that include adjusted ages. All figures that include adjusted ages do not include samples from wells screened in perched zones. The range of uncertainty for the radiocarbon ages (maximum age minus the minimum age) is generally about 7,000 $\mathrm{yr}$ or less. Many adjusted ages are much closer to the minimum age than the maximum age. However, it must be emphasized that the adjusted age is far less robust than the maximum and minimum ages; the probability that the true age lies outside the range of uncertainty is low, but the adjusted age is merely a "best guess" at the true age of the sample.

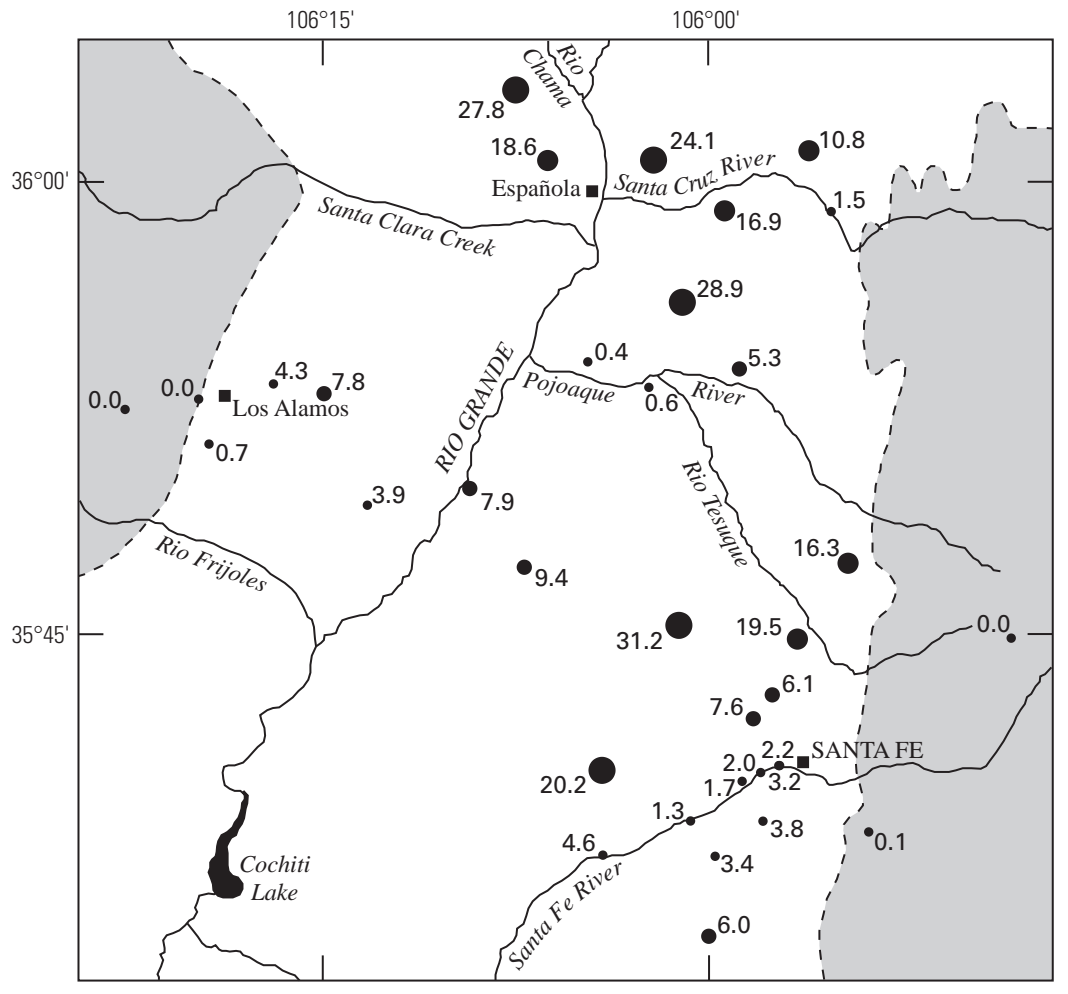

\section{EXPLANATION}

Unadjusted ${ }^{14} \mathrm{C}$ age, in

thousands of years

$>20$

$10-20$
$5-10$

- $<5$

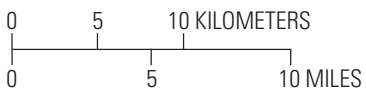

Figure 41. Lateral distribution of unadjusted ${ }^{14} \mathrm{C}$ age. Shaded area is the mountain block; dashed line is the mountain front. 


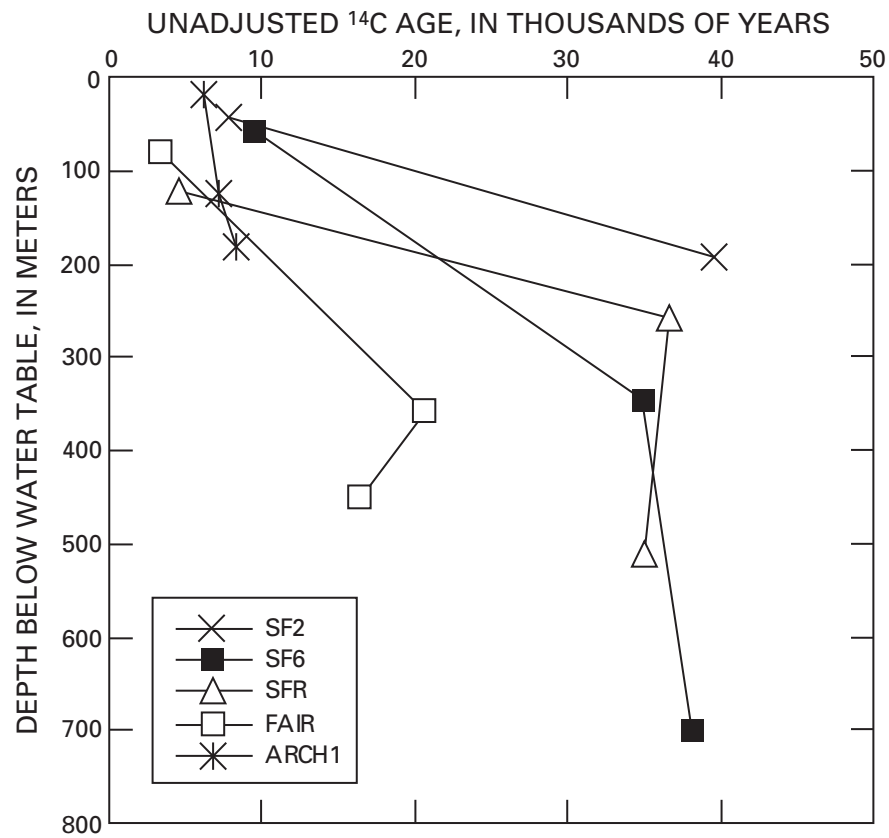

Figure 42. Vertical distribution of unadjusted ${ }^{14} \mathrm{C}$ age in nested piezometers.

\section{Noble Gases}

Dissolved gas concentrations and modeled recharge parameters are presented in table 11. Fifty-eight samples were analyzed for dissolved gases, including $\mathrm{N}_{2}, \mathrm{He}, \mathrm{Ne}, \mathrm{Ar}$, $\mathrm{Kr}$, and Xe. Measured gas concentrations are unreliable in four samples due to either an ice blockage during extraction (WR23-01, WSFRA-01, and WMWA-01) or an air bubble in the sample tube (SYOUNG-01), and neither recharge parameters nor He components were modeled for these samples. Uncertainties in the measured gas concentrations for sample WESP2-01 are larger than those listed in the section entitled "Sample Collection and Analysis" because the sample had to be split multiple times prior to analysis due to its extremely high He concentration. Measured gas concentrations in replicate sample pairs WAS1-01/WAS1-01R and WSM-02/ WSM-02R do not differ by more than twice the $1-\sigma$ analytical uncertainties listed in the section entitled "Sample Collection and Analysis," as expected.

\section{Standard Recharge Parameters}

Standard recharge parameters $\left(\mathrm{T}_{\mathrm{rs}}, \mathrm{A}_{\mathrm{e}}\right.$, and $\left.\mathrm{F}\right)$ were modeled assuming a recharge elevation equal to the elevation of the sample location $\left(\mathrm{H}_{\mathrm{r}}=\mathrm{H}_{\mathrm{rs}}\right.$, see table 1 and section entitled "Methods") and are presented in table 11. The $\mathrm{P}_{\mathrm{r}}$ value assumed in the derivation of $\mathrm{T}_{\mathrm{rs}}, \mathrm{A}_{\mathrm{e}}$, and $\mathrm{F}$ is therefore computed from $\mathrm{H}_{\mathrm{rws}}$ (table 11). $\mathrm{N}_{2}, \mathrm{Ne}, \mathrm{Ar}, \mathrm{Kr}$, and Xe were used in the derivation of recharge parameters; He was excluded because it can have subsurface sources
$\left(\mathrm{He}_{\text {terr }}\right)$. An exception was made in the case of six samples (table 11) for which measured He concentrations were $>1$ percent ( $1-\sigma$ measurement uncertainty) lower than modeled concentrations when He was excluded from the inversion, clearly indicating an absence of $\mathrm{He}_{\text {terr }} . \mathrm{N}_{2}$ was used in the derivation of recharge parameters because basin ground waters are generally oxygenated (table 3 ), meaning that denitrification is generally not occurring. An exception was made in the case of four samples (table 11) for which measured $\mathrm{N}_{2}$ concentrations were $>6$ percent $(2-\sigma$ measurement uncertainty) higher than the modeled concentrations when $\mathrm{N}_{2}$ was excluded from the inversion because this clear $\mathrm{N}_{2}$ excess indicates denitrification.

Model fits $\left(\chi^{2}\right)$ indicate a probability $<0.05$ for only two samples (table 11). Uncertainties in modeled $\mathrm{T}_{\mathrm{rs}}$ values were calculated using a Monte Carlo approach in which 5,000 statistically possible synthetic samples were randomly created for each real sample based on measured gas concentrations and known gas measurement uncertainties. Uncertainties in the recharge parameters for each real sample were then determined from the range of variation in parameters derived from the associated batch of synthetic samples. $\mathrm{T}_{\mathrm{rs}}$ uncertainties are generally $0.5^{\circ}-1.5^{\circ} \mathrm{C}$ for samples collected in 2005 and analyzed at the USGS laboratory (majority of samples). Uncertainties are larger, generally $1.0^{\circ}-2.5^{\circ} \mathrm{C}$, for samples analyzed by the Utah laboratory and samples collected in 2004 and analyzed by the USGS laboratory, the former having larger measurement uncertainties and the latter lacking Xe measurements. The computed $\mathrm{T}_{\mathrm{rs}}$ for sample WLEYB-01 is questionable because the sampled water may have resided in a storage tank for an unknown period prior to sampling, possibly allowing dissolved gases in the sample to re-equilibrate to the shallow ground temperature at the well location.

Figure 45 shows the lateral distribution of $\mathrm{T}_{\mathrm{rs}}$ in the basinfill. Samples collected from perched zones are excluded from figure 45 and all subsequent figures showing the distribution of recharge parameters in the basin-fill. Sample WSM-02 is shown in all recharge parameter figures for well SM because sample WSM-01 was collected about 8 months prior to most of the rest of the samples, and both samples WSM-01 and WSM-03 have higher $\mathrm{T}_{\mathrm{rs}}$ uncertainties. $\mathrm{T}_{\mathrm{rs}}$ values range from $4.4^{\circ} \mathrm{C}$ to $23.2^{\circ} \mathrm{C}$. The warmest $\mathrm{T}_{\mathrm{rs}}$ values are from samples collected in the Pajarito Plateau area. Four of the six samples from the plateau area have $\mathrm{T}_{\mathrm{rs}}$ values $>19^{\circ} \mathrm{C}$, similar to regional water table temperatures on the plateau $\left(18^{\circ}-20^{\circ} \mathrm{C}\right.$; see section entitled "Local $\mathrm{H}_{\mathrm{r}}-\mathrm{T}_{\mathrm{r}}$ Relationship"). These $\mathrm{T}_{\mathrm{rs}}$ values are consistent with all recharge to the regional aquifer occurring on the plateau, or 100 percent BFR. The other two samples from the plateau area, WR18-01 and S4C-01, have $\mathrm{T}_{\mathrm{rs}}$ values of $11.8^{\circ} \mathrm{C}$ and $12.9^{\circ} \mathrm{C}$, respectively. These are well below regional water table temperatures on the plateau. Because the computed $\mathrm{T}_{\mathrm{r}}$ for a sample always decreases when the assumed $\mathrm{H}_{\mathrm{r}}$ is increased, and $\mathrm{T}_{\mathrm{rs}}$ is 


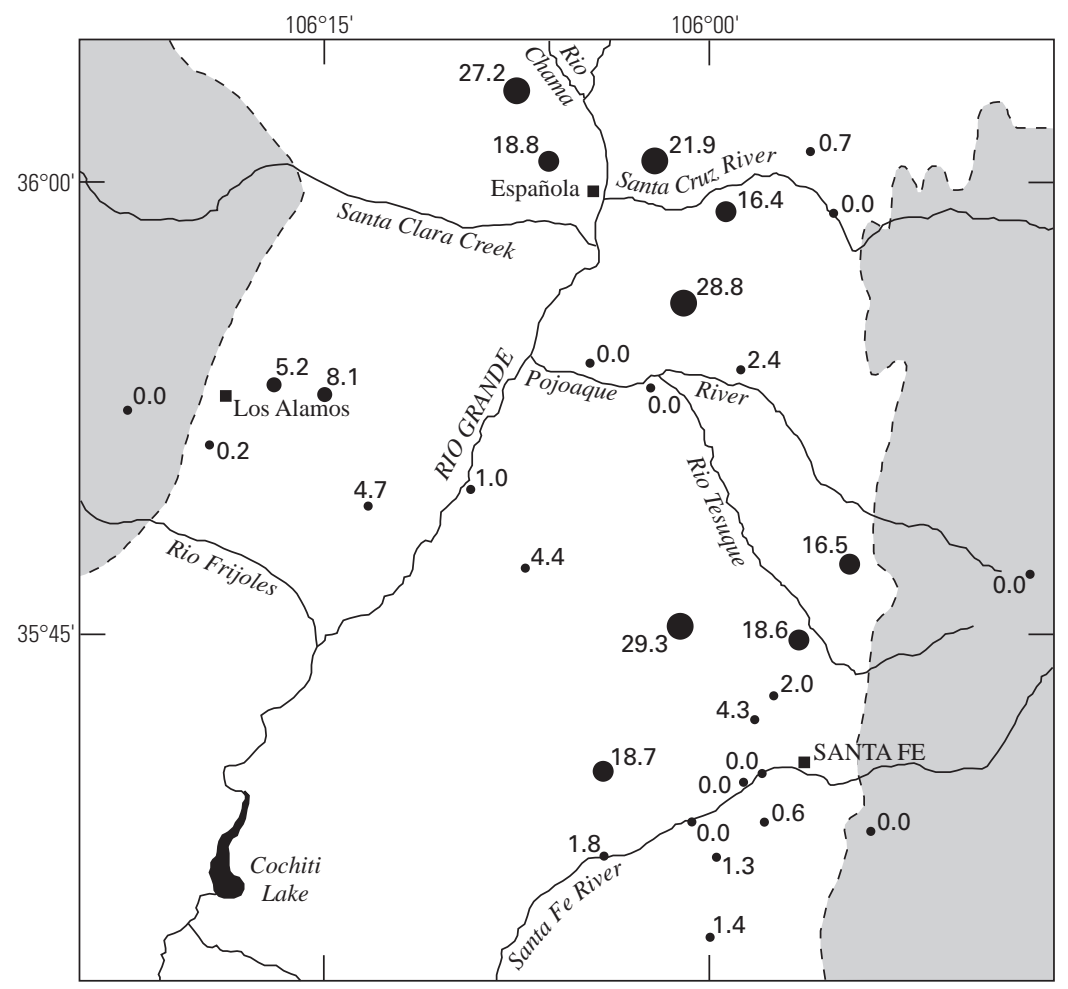

EXPLANATION

Adjusted ${ }^{14} \mathrm{C}$ age, in

thousands of years

- $<5$

- $5-10$

10-20

$>20$

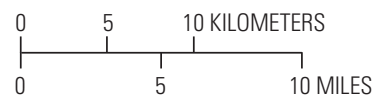

Figure 43. Lateral distribution of adjusted ${ }^{14} \mathrm{C}$ age. Shaded area is the mountain block; dashed line is the mountain front. computed assuming $\mathrm{H}_{\mathrm{r}}=\mathrm{H}_{\mathrm{rs}}$ (lowest possible recharge elevation), the true $\mathrm{T}_{\mathrm{r}}$ for a sample may be colder than $\mathrm{T}_{\mathrm{rs}}$, but not warmer. Therefore, these two samples apparently contain some amount of water recharged either at elevations above the plateau (MBR) or recharged in the Pleistocene Epoch >11,550 yr ago (paleowater) when mean annual air temperatures, and thus water table temperatures, were about $5^{\circ} \mathrm{C}$ cooler than they are now in the southwestern United States (Phillips and others, 1986; Stute and others, 1992). The preferred adjusted radiocarbon age of sample WR18-01 is $162 \mathrm{yr}$ (table 9), and an unadjusted radiocarbon age for Spring 4C in Longmire and others (2007) is $3,531 \mathrm{yr}$, indicating that the two samples probably contain little paleowater, and their lower $\mathrm{T}_{\mathrm{rs}}$ values are a result of MBR. However, it is unclear whether Spring $4 \mathrm{C}$ discharges water from the regional aquifer, a perched aquifer, or a mixture of both based on its location. An alternative hypothesis for S4C-01 is that its low $\mathrm{T}_{\mathrm{rs}}$ is due to the sample containing mostly water from a perched aquifer, not MBR; a perched aquifer would likely have a water table temperature well below that of the regional aquifer, closer to the $\mathrm{T}_{\mathrm{rs}}$ of sample WLAOB-01 $\left(11.1^{\circ} \mathrm{C}\right)$.

Samples from the remainder of the basin have $\mathrm{T}_{\mathrm{rs}}$ values of $4.4^{\circ}-15.7^{\circ} \mathrm{C}$. Several have $\mathrm{T}_{\mathrm{rs}}$ values $<13^{\circ} \mathrm{C}$, the minimum water table temperature in the basin-fill on the east side of the basin (see section entitled "Local $\mathrm{H}_{\mathrm{r}}-\mathrm{T}_{\mathrm{r}}$ Relationship"). These samples must contain MBR or paleowater or both. $\mathrm{T}_{\mathrm{rs}}$ is plotted versus preferred adjusted radiocarbon age (Pajarito Plateau area samples excluded) in figure 46. Samples with $\mathrm{T}_{\mathrm{rs}}$ values $<13^{\circ} \mathrm{C}$ are not limited to those that recharged during the Pleistocene. Samples with adjusted ages $>25,000 \mathrm{yr}$ have the coldest $\mathrm{T}_{\mathrm{rs}}$ values, but there is no obvious correlation between $\mathrm{T}_{\mathrm{rs}}$ and age for samples with adjusted ages $<25,000 \mathrm{yr}$. Therefore, at least some of the samples from the east side of the basin must contain some amount of MBR.

$\mathrm{T}_{\mathrm{rs}}$ values become warmer farther from the mountain front in many parts of the basin, including near the town of Los Alamos, the upper Santa Cruz River corridor, the lower Pojoaque River corridor, along the Santa Fe River west of Santa Fe (downstream of the public supply well TOR with a $\mathrm{T}_{\mathrm{rs}}$ value of $13.1^{\circ} \mathrm{C}$ ), and lower Cañada Ancha. This trend is consistent with samples farther from the mountain front containing larger fractions of BFR in these areas, which is in turn consistent with stream loss occurring well out into the basin, not just near the mountain front. Figure 47 shows the vertical distribution of $\mathrm{T}_{\mathrm{rs}}$ in the nested piezometers in the Southeast zone. $\mathrm{T}_{\mathrm{rs}}$ values clearly decrease with depth, either due to larger fractions of MBR or paleowater or both at depth. The adjusted radiocarbon ages suggest that, for each piezometer nest, only the shallowest sample was recharged during the Holocene Epoch $(<11,550 \mathrm{yr}$ ago $)$ in the current climate regime, meaning that the deeper samples with lower $\mathrm{T}_{\mathrm{rs}}$ values do not necessarily contain larger fractions of MBR.

\section{Local $\mathrm{H}_{\mathrm{r}}-\mathrm{T}_{\mathrm{r}}$ Relationship}

Table 12 lists $\mathrm{T}_{\mathrm{a}}$ values compiled from 20 meteorological stations located at different elevations in the Española Basin and adjacent areas. The regression line through the $\mathrm{T}_{\mathrm{a}}$ data in 
figure 48 indicates that $\mathrm{T}_{\mathrm{a}}$ decreases at an average rate of $6.4^{\circ} \mathrm{C} / \mathrm{km}$ of elevation gain in the Española Basin area, similar to atmospheric lapse rates reported for other parts of the western United States. The cities of Española, Santa Fe, and Los Alamos, located at elevations of about 1,700 masl, 2,100 masl, and 2,200 masl, respectively, have $\mathrm{T}_{\mathrm{a}}$ values of approximately $11^{\circ} \mathrm{C}, 10^{\circ} \mathrm{C}$, and $9^{\circ} \mathrm{C}$, respectively.

Local $\mathrm{H}_{\mathrm{r}}-\mathrm{T}_{\mathrm{r}}$ relationships for the eastern and western sides of the Española Basin were derived using multiple data types. The most direct method of observing $\mathrm{T}_{\mathrm{r}}$ at a given elevation is to determine $\mathrm{T}_{\mathrm{r}}$ for samples known to have recharged at that elevation. However, in practice this is seldom possible because discrete samples from near the water table can rarely be collected, and, even when they can, some question often still remains regarding whether or not the sampled water recharged at the sample location/elevation. The next most direct approach is to measure the water table temperature at different elevations. Table 13 lists water table temperature measurements made in this study, along with the few data that could be obtained from prior studies. These measurements were made with a down-hole temperature probe either in the water at the water table or in the air column immediately above it. Measurement depths were $\geq 8 \mathrm{~m}$ bgs, below the depth of significant seasonal temperature fluctuations. Few water table temperature data are available due to the scarcity of open wells into which temperature probes can be lowered.

On the east side of the basin, water table temperatures form a linear trend and are generally $3^{\circ}-5^{\circ} \mathrm{C}$ above $\mathrm{T}_{\mathrm{a}}$ in the basin-fill (figs. $49 \mathrm{~A}$ and $C$ ). Measurement depths are $8-65 \mathrm{~m}$ bgs. The one exception is Archery 1A, with a water

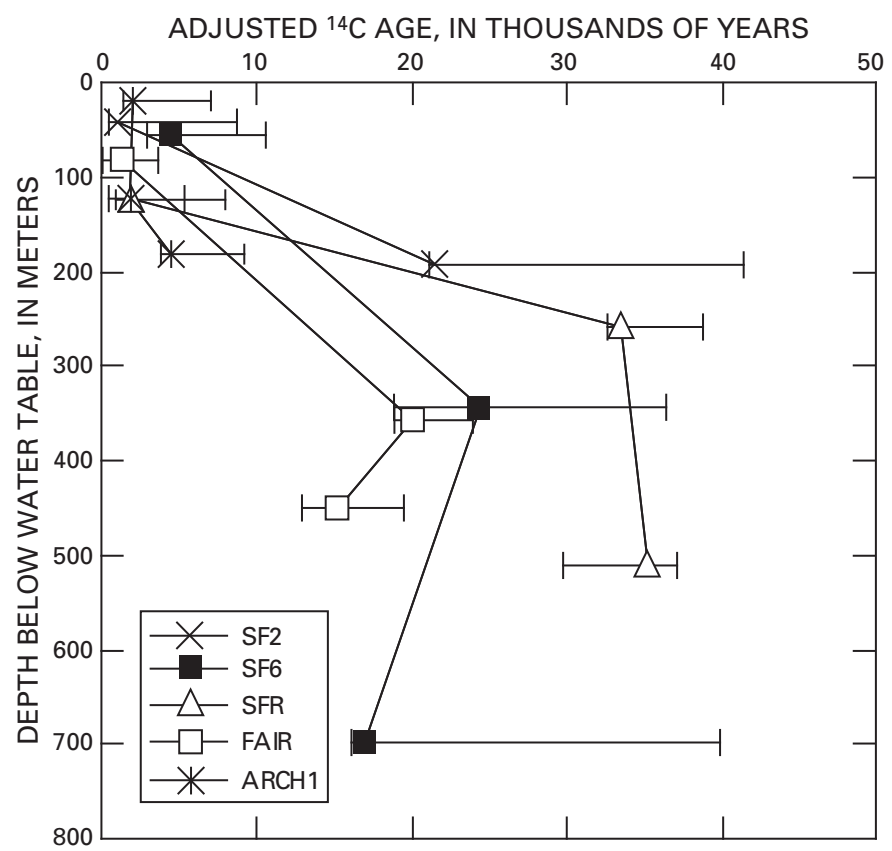

Figure 44. Vertical distribution of adjusted ${ }^{14} \mathrm{C}$ age in nested piezometers. table depth of $152 \mathrm{~m}$ bgs and a water table temperature about $6^{\circ} \mathrm{C}$ above $\mathrm{T}_{\mathrm{a}}$. Water table temperatures in the basin-fill near the mountain front are $13^{\circ}-14^{\circ} \mathrm{C}$ (Archery $1 \mathrm{~A}$ again being the exception). On the west side of the basin, the three water table temperatures were measured in wells located on the Pajarito Plateau (figs. $49 B$ and $D$ ). These points form a roughly linear trend and are generally $8^{\circ}-10^{\circ} \mathrm{C}$ above $\mathrm{T}_{\mathrm{a}}$. Water table temperatures are so much warmer than $\mathrm{T}_{\mathrm{a}}$ because water table depths across most of the plateau are 200-400 m bgs, meaning that water table temperatures are significantly influenced by the geothermal gradient. The water table temperature trendline in figure $49 \mathrm{D}$ suggests that the water table temperature on the plateau near the mountain front is about $18^{\circ} \mathrm{C}$.

Because only one water table temperature measurement could be obtained in the mountains, ground-water-discharge temperature measurements from springs and shallow wells were utilized (table 13). Ground-water-discharge temperatures are not a direct measure of the local water table temperature. However, they should closely approximate the mean annual ground temperature $\left(\mathrm{T}_{\mathrm{g}}\right)$ at depths $<100 \mathrm{~m}$ bgs. $\mathrm{T}_{\mathrm{g}}$ should in turn closely approximate the mean annual water table temperature, assuming the water table is $<100 \mathrm{~m}$ bgs. This assumption is supported by both the depth-to-water measurements in the mountain wells in this study (table 2) and by water-level data from other mountain locations underlain by crystalline rock (Manning and Caine, 2007). Spring and well discharge temperatures will approximate $\mathrm{T}_{\mathrm{g}}$ provided that (a) discharge rates are sufficiently high to prevent thermal re-equilibration during discharge, (b) well screens are not significantly deeper than $100 \mathrm{~m}$ bgs, and (c) the ground water has not circulated significantly deeper than $100 \mathrm{~m}$ bgs. In this study, discharge temperatures were measured for springs and wells with estimated discharge rates of 4 to $>100$ gallons per minute. These flow rates are probably sufficient to prevent significant warming or cooling of the water as it ascends through the shallowest depths ( $<3 \mathrm{~m} \mathrm{bgs}$ ) where ground temperatures undergo large seasonal fluctuations. Temperature measurements were made at the spring orifice, or, in the case of wells, directly at the wellhead. Well discharge temperatures were measured from wells with mid-screen depths of $13-110 \mathrm{~m}$ bgs. Apparent ${ }^{3} \mathrm{H} /{ }^{\beta} \mathrm{He}$ ages $(<20 \mathrm{yr}$, see "Helium and Tritium" section), field parameters, water chemistry (if available), and the local geology did not suggest deep ground-water circulation at any of the measurement locations. If the discharge temperatures differ substantially from $T_{g}$, they should be warmer, not cooler, given the following factors: (a) discharge measurements were made in the summer and early fall when ground temperatures at depths $<3 \mathrm{~m} \mathrm{bgs}$ and wellhead piping are warmer than $\mathrm{T}_{\mathrm{g}}$; (b) if ground water does circulate deeply, it will warm above $\mathrm{T}_{\mathrm{g}}$; and (c) submersible well pumps can warm water slightly as they pump it. Therefore, at the least, the discharge temperatures provide a reliable upper limit on $\mathrm{T}_{\mathrm{g}}$ in the mountains. 
Table 11. Dissolved gas concentrations and modeled recharge parameters.

$\left[\mathrm{cm}^{3} \mathrm{STP} / \mathrm{g}\right.$, cubic $\mathrm{cm}$ at standard temperature and pressure per gram of water; $\mathrm{H}_{\mathrm{rw}}$, standard recharge water table elevation; $\mathrm{T}$, standard recharge temperature; uncert, 1 -sigma uncertainty; $\mathrm{A}_{\mathrm{e}}, \mathrm{F}$, and $\chi^{2}$ defined in text; $\mathrm{T}_{\text {rmax }}, \mathrm{T}_{\text {rmin }}$, and $\mathrm{T}_{\text {rav }}$, maximum, minimum, and average recharge temperature, respectively; $\mathrm{H}_{\mathrm{rmin}}, \mathrm{H}_{\mathrm{rmax}}$, and $\mathrm{H}_{\mathrm{rav}}$, minimum, maximum, and average recharge elevation, respectively; $\mathrm{X}_{\min }$, minimum MBR fraction; $\mathrm{U}$, undetermined; CCT, clamped copper tube; DS, diffusion sampler; USGS, U.S. Geological Survey Noble Gas Laboratory; Utah, University of Utah Noble Gas Laboratory; NC, not computed; NA, not applicable.

Notes: 1 , He included in recharge parameter derivation because $>1 \%$ low if exclude; $2, \mathrm{~N}_{2}$ excluded in recharge parameter derivation because $>6 \%$ excess, probably due to denitrification; $3, \mathrm{~N}_{2}$ excluded because $>6 \%$ depleted; $4, \chi^{2}$ unacceptably high; 5 , Unreliable gas concentrations due to ice blockage during gas extraction; 6, Unreliable gas concentrations due to bubble in sample tube; 7 , Gas concentrations more uncertain because sample was split multiple times due to very high He concentration; 8 , Assumed $\mathrm{H}_{\mathrm{rav}}=\mathrm{H}_{\mathrm{rs}}$ because well screened in shallow perched zone, or local water table elevation similar to nearby major stream/river]

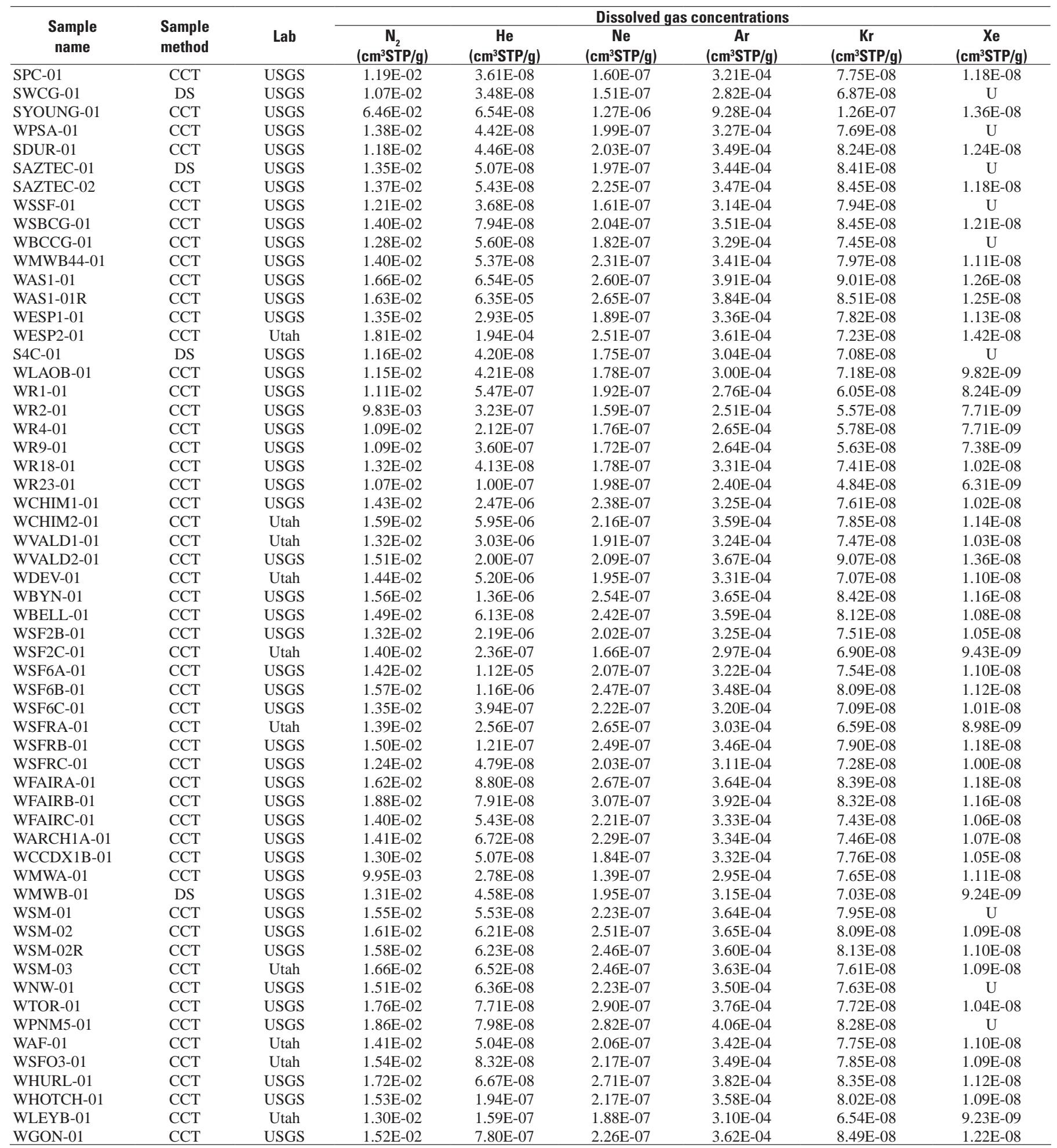


Table 11. Dissolved gas concentrations and modeled recharge parameters.-Continued

$\left[\mathrm{cm}^{3} \mathrm{STP} / \mathrm{g}\right.$, cubic $\mathrm{cm}$ at standard temperature and pressure per gram of water; $\mathrm{H}_{\mathrm{rws}}$, standard recharge water table elevation; $\mathrm{T}_{\mathrm{rs}}$, standard recharge temperature; uncert, 1 -sigma uncertainty; $\mathrm{A}_{\mathrm{e}}, \mathrm{F}$, and $\chi^{2}$ defined in text; $\mathrm{T}_{\text {rmax }}, \mathrm{T}_{\text {rmin }}$, and $\mathrm{T}_{\text {rav }}$, maximum, minimum, and average recharge temperature, respectively; $\mathrm{H}_{\text {rmin }}, \mathrm{H}_{\text {rmax }}$, and $\mathrm{H}_{\text {rav }}$, minimum, maximum, and average recharge elevation, respectively; $\mathrm{X}_{\min }$, minimum MBR fraction; U, undetermined; CCT, clamped copper tube; DS, diffusion sampler; USGS, U.S. Geological Survey Noble Gas Laboratory; Utah, University of Utah Noble Gas Laboratory; NC, not computed; NA, not applicable.

Notes: 1 , He included in recharge parameter derivation because $>1 \%$ low if exclude; $2, \mathrm{~N}_{2}$ excluded in recharge parameter derivation because $>6 \%$ excess, probably due to denitrification; $3, \mathrm{~N}_{2}$ excluded because $>6 \%$ depleted; $4, \chi^{2}$ unacceptably high; 5 , Unreliable gas concentrations due to ice blockage during gas extraction; 6 , Unreliable gas concentrations due to bubble in sample tube; 7 , Gas concentrations more uncertain because sample was split multiple times due to very high He concentration; 8 , Assumed $\mathrm{H}_{\mathrm{rav}}=\mathrm{H}_{\mathrm{rs}}$ because well screened in shallow perched zone, or local water table elevation similar to nearby major stream/river]

\begin{tabular}{|c|c|c|c|c|c|c|c|c|c|c|c|c|c|c|}
\hline $\begin{array}{c}\text { Sample } \\
\text { name }\end{array}$ & \multicolumn{13}{|c|}{ Modeled recharge parameters } & Notes \\
\hline SPC-01 & 2689 & 4.7 & 0.4 & 0.0001 & 0.000 & 0.48 & $\mathrm{NC}$ & $\mathrm{NC}$ & 3.9 & 2689 & 3171 & 2930 & NA & \\
\hline SWCG-01 & 2449 & 11.1 & 0.2 & 0.0000 & 0.000 & 2.45 & $\mathrm{NC}$ & $\mathrm{NC}$ & 10.2 & 2449 & 2744 & 2596 & NA & 1 \\
\hline WPSA-01 & 2764 & 7.3 & 1.0 & 0.0173 & 0.690 & 4.00 & $\mathrm{NC}$ & $\mathrm{NC}$ & 6.7 & 2764 & 3140 & 2952 & NA & 1 \\
\hline SDUR-01 & 2712 & 3.9 & 0.8 & 0.0086 & 0.622 & 2.35 & $\mathrm{NC}$ & $\mathrm{NC}$ & 3.6 & 2712 & 2927 & 2819 & NA & 1,3 \\
\hline SAZTEC-01 & 2333 & 5.1 & 0.8 & 0.0017 & 0.000 & 0.72 & $\mathrm{NC}$ & $\mathrm{NC}$ & 4.2 & 2333 & 2866 & 2599 & NA & \\
\hline WSBCG-01 & 2718 & 3.9 & 1.2 & 0.0033 & 0.196 & 0.56 & $\mathrm{NC}$ & $\mathrm{NC}$ & 3.2 & 2718 & 3171 & 2944 & NA & \\
\hline WBCCG-01 & 2529 & 7.9 & 1.1 & 0.0189 & 0.795 & 1.18 & $\mathrm{NC}$ & $\mathrm{NC}$ & 7.2 & 2529 & 3030 & 2780 & NA & \\
\hline WMWB44-01 & 2294 & 8.0 & 0.6 & 0.0033 & 0.000 & 3.63 & $\mathrm{NC}$ & $\mathrm{NC}$ & 7.2 & 2294 & 2744 & 2519 & NA & 1 \\
\hline WAS1-01 & 1710 & 6.5 & 1.0 & 0.0057 & 0.124 & 0.25 & $\mathrm{NC}$ & $\mathrm{NC}$ & 3.7 & $\mathrm{NC}$ & $\mathrm{NC}$ & 2600 & $\mathrm{NC}$ & \\
\hline WAS1-01R & 1710 & 7.4 & 0.7 & 0.0049 & 0.000 & 1.65 & $\mathrm{NC}$ & $\mathrm{NC}$ & 4.5 & $\mathrm{NC}$ & $\mathrm{NC}$ & 2560 & $\mathrm{NC}$ & \\
\hline WESP1-01 & 1689 & 9.4 & 0.9 & 0.0099 & 0.773 & 1.49 & $\mathrm{NC}$ & $\mathrm{NC}$ & 7.1 & $\mathrm{NC}$ & $\mathrm{NC}$ & 2400 & $\mathrm{NC}$ & \\
\hline WESP2-01 & 1748 & 8.7 & 4.6 & 0.0084 & 0.272 & 36.08 & $\mathrm{NC}$ & $\mathrm{NC}$ & $\mathrm{NC}$ & $\mathrm{NC}$ & $\mathrm{NC}$ & $\mathrm{NC}$ & $\mathrm{NC}$ & 4,7 \\
\hline WR4-01 & 1778 & 21.3 & 1.2 & 0.0054 & 0.647 & 0.65 & 21.3 & 20.1 & 20.7 & 2005 & 2400 & 2203 & 0.00 & \\
\hline WR9-01 & 1735 & 23.2 & 1.3 & 0.0146 & 0.784 & 1.99 & 23.2 & 22.0 & 22.6 & 1946 & 2400 & 2173 & 0.00 & \\
\hline WR18-01 & 1865 & 11.8 & 0.7 & 0.1046 & 0.904 & 2.34 & 10.8 & 10.2 & 10.5 & 2440 & 2820 & 2630 & 0.53 & 1,2 \\
\hline WR23-01 & $\mathrm{NC}$ & $\mathrm{NC}$ & $\mathrm{NC}$ & $\mathrm{NC}$ & $\mathrm{NC}$ & $\mathrm{NC}$ & $\mathrm{NC}$ & $\mathrm{NC}$ & $\mathrm{NC}$ & $\mathrm{NC}$ & $\mathrm{NC}$ & $\mathrm{NC}$ & $\mathrm{NC}$ & 5 \\
\hline WCHIM1-01 & 1857 & 12.4 & 0.7 & 0.0040 & 0.000 & 2.56 & 11.7 & 10.3 & 11.0 & 2050 & 2420 & 2235 & 0.22 & \\
\hline WCHIM2-01 & 1881 & 9.7 & 1.4 & 0.0226 & 0.642 & 5.81 & $\mathrm{NC}$ & $\mathrm{NC}$ & $\mathrm{NC}$ & $\mathrm{NC}$ & $\mathrm{NC}$ & $\mathrm{NC}$ & $\mathrm{NC}$ & \\
\hline WVALD1-01 & 1775 & 11.7 & 1.8 & 0.0165 & 0.776 & 0.63 & $\mathrm{NC}$ & $\mathrm{NC}$ & 11.7 & $\mathrm{NC}$ & $\mathrm{NC}$ & 1775 & $\mathrm{NC}$ & \\
\hline WVALD2-01 & 1778 & 4.4 & 0.6 & 0.0018 & 0.000 & 2.89 & $\mathrm{NC}$ & $\mathrm{NC}$ & 2.0 & $\mathrm{NC}$ & $\mathrm{NC}$ & 2500 & $\mathrm{NC}$ & \\
\hline WDEV-01 & 1748 & 11.0 & 1.5 & 0.0057 & 0.615 & 2.46 & $\mathrm{NC}$ & $\mathrm{NC}$ & 11.0 & $\mathrm{NC}$ & $\mathrm{NC}$ & 1748 & $\mathrm{NC}$ & 2,8 \\
\hline WBYN-01 & 1828 & 8.5 & 1.0 & 0.0046 & 0.000 & 0.54 & 7.0 & 4.2 & 5.6 & 2270 & 3130 & 2700 & 0.76 & \\
\hline WBELL-01 & 1704 & 10.8 & 1.6 & 0.0079 & 0.350 & 1.79 & $\mathrm{NC}$ & $\mathrm{NC}$ & 10.8 & $\mathrm{NC}$ & $\mathrm{NC}$ & 1704 & $\mathrm{NC}$ & 8 \\
\hline WSF2B-01 & 1631 & 11.7 & 1.1 & 0.0019 & 0.000 & 0.05 & $\mathrm{NC}$ & $\mathrm{NC}$ & 11.2 & $\mathrm{NC}$ & $\mathrm{NC}$ & 1760 & $\mathrm{NC}$ & \\
\hline WSF2C-01 & 1625 & 14.3 & 1.4 & 0.1388 & 0.985 & 0.11 & 13.9 & 13.5 & 13.7 & 1860 & 2070 & 1965 & 0.00 & 2 \\
\hline WSF6A-01 & 1782 & 10.6 & 0.6 & 0.0021 & 0.000 & 2.87 & $\mathrm{NC}$ & $\mathrm{NC}$ & 10.3 & $\mathrm{NC}$ & $\mathrm{NC}$ & 1870 & $\mathrm{NC}$ & 2 \\
\hline WCCDX1B-01 & 1925 & 11.1 & 1.4 & 0.0617 & 0.853 & 0.72 & 10.8 & 10.1 & 10.5 & 2130 & 2450 & 2290 & 0.27 & \\
\hline WMWA-01 & $\mathrm{NC}$ & $\mathrm{NC}$ & $\mathrm{NC}$ & $\mathrm{NC}$ & $\mathrm{NC}$ & $\mathrm{NC}$ & $\mathrm{NC}$ & $\mathrm{NC}$ & $\mathrm{NC}$ & $\mathrm{NC}$ & $\mathrm{NC}$ & $\mathrm{NC}$ & $\mathrm{NC}$ & 5 \\
\hline WMWB-01 & 2097 & 14.4 & 1.6 & 0.0303 & 0.741 & 1.31 & $\mathrm{NC}$ & $\mathrm{NC}$ & 14.4 & $\mathrm{NC}$ & $\mathrm{NC}$ & 2097 & $\mathrm{NC}$ & 1,8 \\
\hline WSM-01 & 2028 & 10.8 & 2.1 & 0.0278 & 0.611 & 1.35 & 10.6 & 9.9 & 10.3 & 2190 & 2490 & 2330 & 0.29 & \\
\hline WSM-02 & 2028 & 10.2 & 1.3 & 0.0129 & 0.393 & 0.28 & 9.8 & 8.2 & 9.0 & 2200 & 2680 & 2440 & 0.40 & \\
\hline WSM-02R & 2028 & 9.6 & 1.2 & 0.0100 & 0.352 & 0.38 & 9.2 & 7.4 & 8.3 & 2020 & 2760 & 2390 & 0.48 & \\
\hline WSM-03 & 2028 & 11.4 & 1.7 & 0.0184 & 0.466 & 3.06 & 11.1 & 10.2 & 10.7 & 2170 & 2430 & 2300 & 0.24 & \\
\hline WNW-01 & 2046 & 12.0 & 2.0 & 0.0212 & 0.574 & 1.61 & 11.9 & 11.5 & 11.7 & 2180 & 2300 & 2240 & 0.14 & \\
\hline WTOR-01 & 2016 & 13.1 & 1.3 & 0.0154 & 0.280 & 0.62 & 13.0 & 12.8 & 12.9 & 2100 & 2150 & 2125 & 0.02 & \\
\hline WPNM5-01 & 2005 & 13.0 & 2.5 & 0.0323 & 0.424 & 2.08 & 12.9 & 12.8 & 12.9 & 2110 & 2150 & 2130 & 0.02 & \\
\hline WAF-01 & 1984 & 9.6 & 2.2 & 0.0128 & 0.647 & 0.16 & 9.0 & 7.0 & 8.0 & 2210 & 2810 & 2510 & 0.51 & \\
\hline WSFO3-01 & 2078 & 10.0 & 1.6 & 0.0194 & 0.605 & 2.55 & $\mathrm{NC}$ & $\mathrm{NC}$ & 10.0 & $\mathrm{NC}$ & $\mathrm{NC}$ & 2078 & $\mathrm{NC}$ & \\
\hline WHURL-01 & 2056 & 9.7 & 1.3 & 0.0149 & 0.352 & 0.20 & 9.3 & 7.6 & 8.5 & 2210 & 2740 & 2475 & 0.47 & \\
\hline WHOTCH-01 & 2083 & 10.2 & 1.2 & 0.0252 & 0.622 & 2.44 & $\mathrm{NC}$ & $\mathrm{NC}$ & 10.2 & $\mathrm{NC}$ & $\mathrm{NC}$ & 2083 & $\mathrm{NC}$ & \\
\hline WLEYB-01 & 1858 & 15.7 & 1.6 & 0.0239 & 0.754 & 3.18 & $\mathrm{NC}$ & $\mathrm{NC}$ & 15.7 & $\mathrm{NC}$ & $\mathrm{NC}$ & 1858 & $\mathrm{NC}$ & \\
\hline WGON-01 & 1899 & 6.8 & 0.9 & 0.0041 & 0.174 & 0.34 & $\mathrm{NC}$ & $\mathrm{NC}$ & 5.4 & $\mathrm{NC}$ & $\mathrm{NC}$ & 2310 & $\mathrm{NC}$ & \\
\hline
\end{tabular}




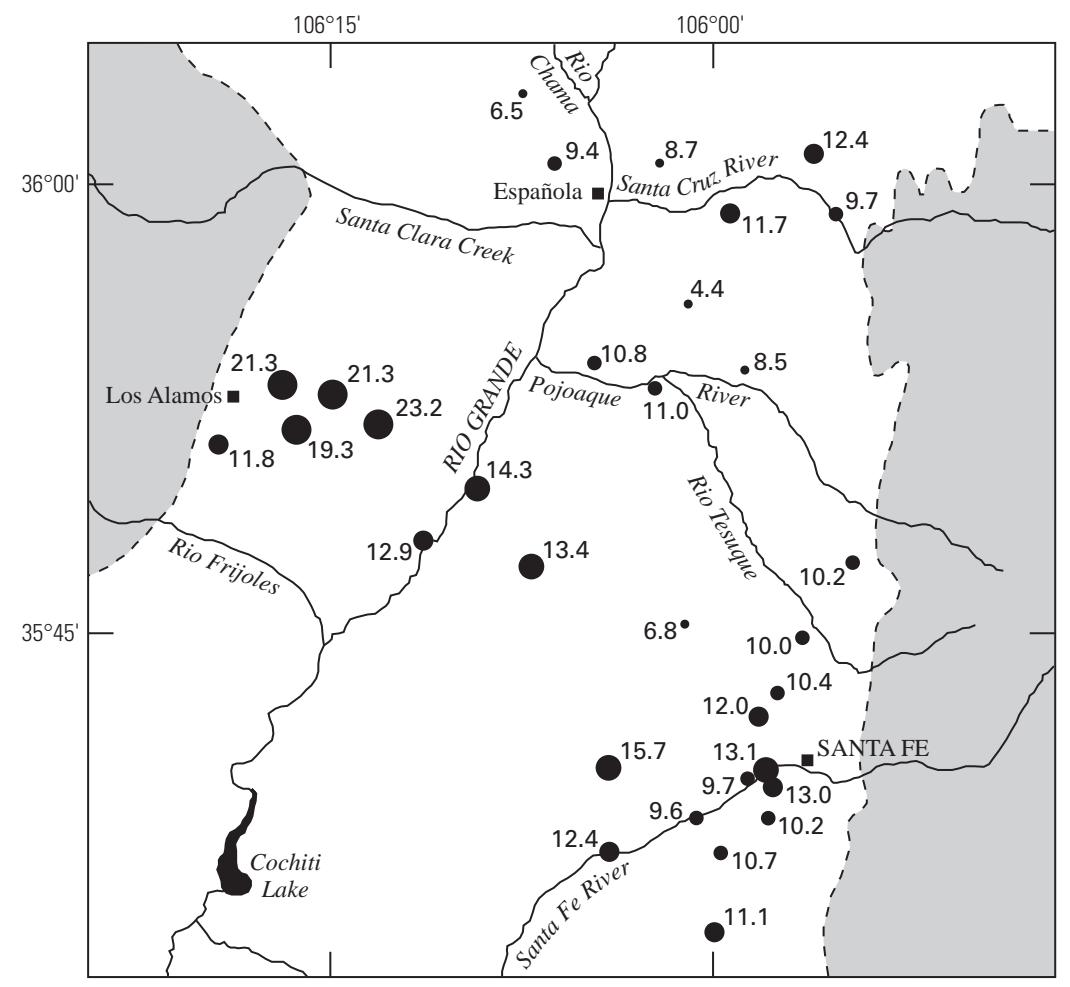

EXPLANATION

$\mathrm{T}_{\mathrm{rs}}$, in degrees celsius

$>16$

13-16

- $11-1$

- 9-11

- $<9$

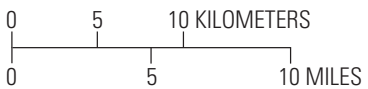

Figure 45. Lateral distribution of $\mathrm{T}_{\mathrm{rs}}$ (standard recharge temperature). Shaded area is the mountain block; dashed line is the mountain front.

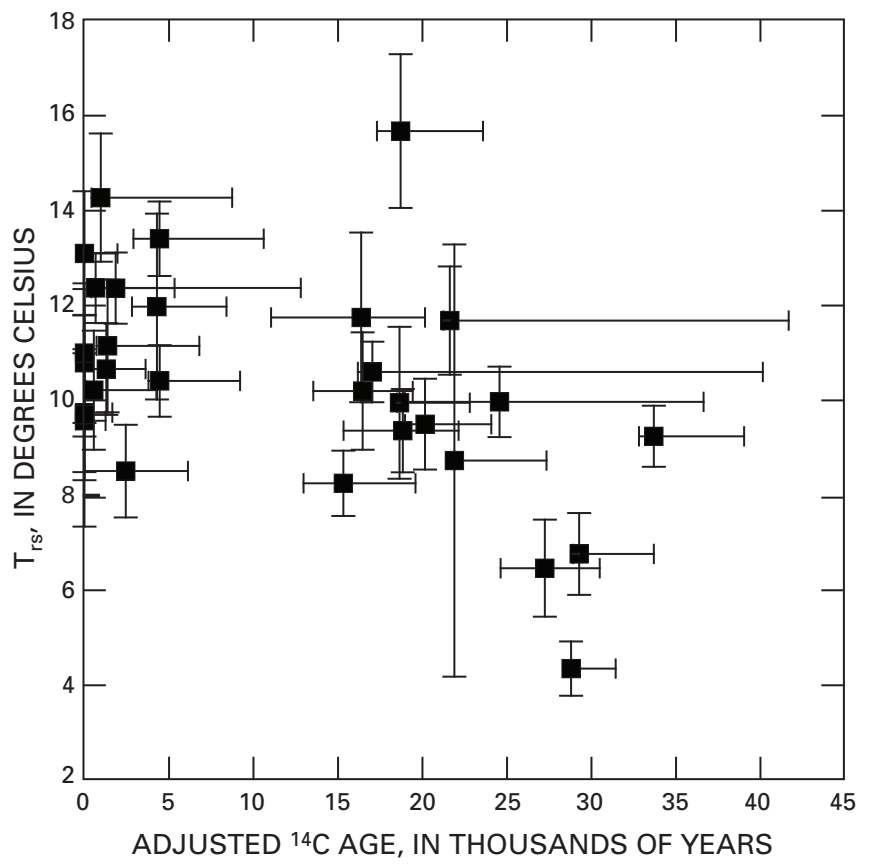

Figure 46. $\quad \mathrm{T}_{\mathrm{rs}}$ (standard recharge temperature) versus adjusted ${ }^{14} \mathrm{C}$ age.

On the east side of the basin, discharge temperatures form a linear trend similar to that defined by the water table temperatures, and are generally $1^{\circ}-3^{\circ} \mathrm{C}$ above $\mathrm{T}_{\mathrm{a}}$ (figs. $49 \mathrm{~A}$ and $C$ ). This is consistent with the fact that water table depths in both the basin-fill and the mountain block are generally <100 m bgs. On the west side of the basin, the discharge temperatures do not

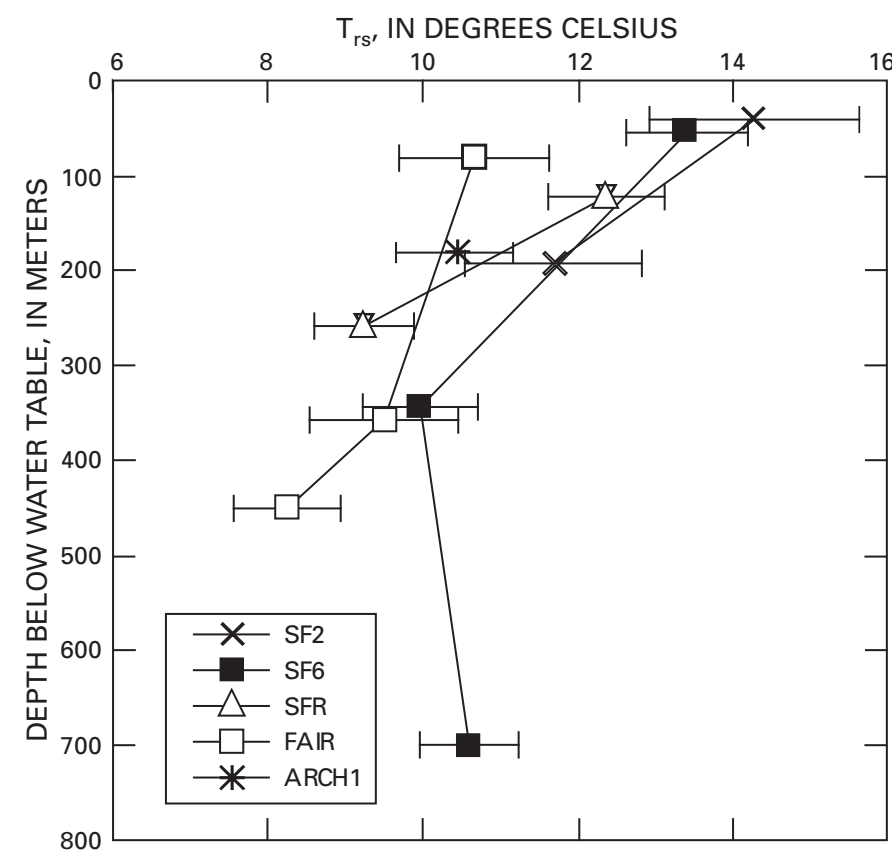

Figure 47. Vertical distribution of $\mathrm{T}_{\mathrm{rs}}$ (standard recharge temperature) in nested piezometers.

form a linear trend (figs. $49 B$ and $D$ ), but there are only three data points. The line defining the upper limit of the discharge temperatures is $3^{\circ}-4^{\circ} \mathrm{C}$ above $\mathrm{T}_{\mathrm{a}}$. This line is substantially different (cooler) than the water table temperature trendline because water table depths are much shallower in the mountain block than on the plateau. 
Table 12. Mean annual air temperatures.

[T, mean annual air temperature; WRCC, Western Regional Climate Center meteorological station data (http://www.wrcc.dri.edu); NRCS, U.S. Department of Agriculture National Resources Conservation Service SNOTEL site data (http://www.wcc.nrcs.usda.gov/snotel)]

\begin{tabular}{|c|c|c|c|c|c|c|}
\hline \multirow[b]{2}{*}{ Station name } & \multirow[b]{2}{*}{ Source } & \multicolumn{3}{|c|}{ Station location ${ }^{1}$} & \multirow[b]{2}{*}{$\begin{array}{l}\text { Period of } \\
\text { record }\end{array}$} & \multirow[b]{2}{*}{$\begin{array}{c}\mathrm{T}_{\mathrm{a}} \\
\left({ }^{\circ} \mathrm{C}\right)\end{array}$} \\
\hline & & $\begin{array}{c}\text { Easting } \\
(\mathrm{m})\end{array}$ & $\begin{array}{l}\text { Northing } \\
\text { (m) }\end{array}$ & $\begin{array}{c}\text { Elevation } \\
(\mathrm{m})\end{array}$ & & \\
\hline Española & WRCC & 402410 & 3984288 & 1720 & $1914-2005$ & 11.1 \\
\hline Santa Fe & WRCC & 418611 & 3948996 & 2198 & $1867-1972$ & 9.6 \\
\hline Santa Fe 2 & WRCC & 410997 & 3941674 & 2049 & $1972-2005$ & 10.2 \\
\hline Alcalde & WRCC & 404034 & 3995363 & 1732 & $1953-2005$ & 10.6 \\
\hline Cochiti Dam & WRCC & 380832 & 3943876 & 1695 & $1975-2005$ & 12.6 \\
\hline Los Alamos & WRCC & 381179 & 3969757 & 2244 & $1942-2005$ & 9.1 \\
\hline Abiquiu Dam & WRCC & 371244 & 4010578 & 1945 & $1957-2005$ & 10.4 \\
\hline El Rito & WRCC & 393847 & 4021367 & 2095 & $1933-2005$ & 9.4 \\
\hline Wolf Canyon & WRCC & 342219 & 3979614 & 2506 & $1952-2005$ & 4.7 \\
\hline Jemez Springs & WRCC & 347882 & 3959172 & 1909 & 1914-2005 & 11.0 \\
\hline Gallegos Peak & NRCS & 449882 & 4005462 & 2988 & 1989-2005 & 2.9 \\
\hline Quemazon & NRCS & 374465 & 3976033 & 2896 & 1989-2006 & 3.5 \\
\hline Wesner Springs & NRCS & 451018 & 3958991 & 3390 & 1989-2006 & 1.5 \\
\hline
\end{tabular}

${ }^{1}$ Coordinates $=$ UTM, NAD27, Zone 13S.

Snowmelt commonly constitutes a large component of mountain ground-water recharge. Because fractured-rock aquifers have very low porosity, rapid infiltration of snowmelt water could cause mountain water tables to rise close to the ground surface in the mountains in the spring when most recharge occurs. Infiltrating snowmelt water (near $0^{\circ} \mathrm{C}$ ) may therefore warm little before entering the saturated zone. These conditions could result in $\mathrm{T}_{\mathrm{r}}$ values substantially below $\mathrm{T}_{\mathrm{g}}$. To address this possibility, $\mathrm{T}_{\mathrm{rs}}$ values from mountain springs and wells were employed as a third type of data in deriving the local $\mathrm{H}_{\mathrm{r}}-\mathrm{T}_{\mathrm{r}}$ relationship (table 11). On the eastern side of the basin, $\mathrm{T}_{\mathrm{rs}}$ values are $1^{\circ}-6^{\circ} \mathrm{C}$ less than the discharge temperature from the same well or spring, suggesting that $\mathrm{T}_{\mathrm{rs}}$ is indeed typically less than $\mathrm{T}_{\mathrm{g}}$ (fig. 49A). Manning and Solomon (2003) observed similar results in the Wasatch Mountains, Utah. However, it is also possible that $\mathrm{T}_{\mathrm{rs}}$ is less than the discharge temperature because the sampled water actually recharged at higher elevation. Recall that $\mathrm{T}_{\mathrm{rs}}$ is computed assuming that the recharge elevation is equal to the water table at the sample location; that is, the water recharged at the sample location. If $T_{r}$ is computed for each of the eastern mountain samples assuming higher $\mathrm{H}_{\mathrm{r}}$ values (the maximum $\mathrm{H}_{\mathrm{r}}$ being the top of the surfacewatershed in which the well or spring is located), the resulting points $\left(\mathrm{H}_{\mathrm{r}}-\mathrm{T}_{\mathrm{r}}\right.$ pairs) will plot farther to the right on figure $49 \mathrm{~A}$, close to the discharge temperature trendline shown in figure $49 \mathrm{C}$. On the west side of the basin, $\mathrm{T}_{\mathrm{rs}}$ is only $0^{\circ}-2^{\circ} \mathrm{C}$ less than the discharge temperature from the same well or spring. This suggests that water tables may rise less in response to spring snowmelt in the Jemez Mountains, or that recharge occurred closer to the sample elevation for these samples.

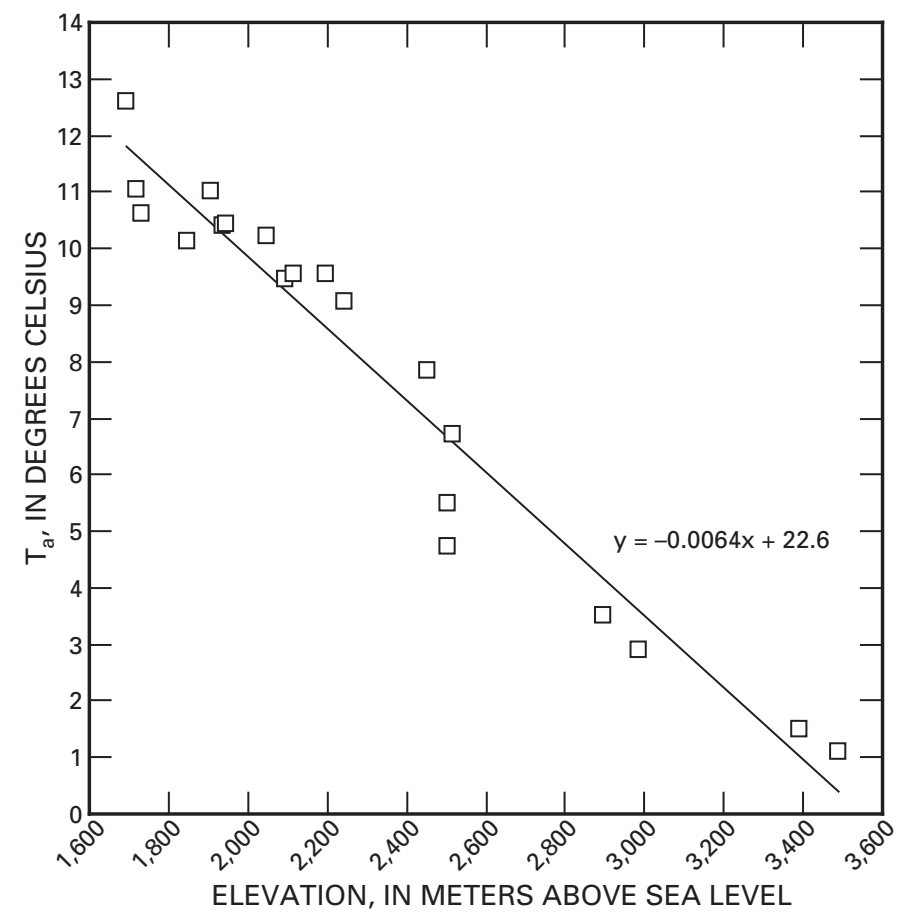

Figure 48. $T_{a}$ (mean annual air temperature) versus elevation.

Regardless of why $\mathrm{T}_{\mathrm{rs}}$ values are typically less than the discharge temperatures at a given elevation, the lines defining the lower limit of the $\mathrm{T}_{\mathrm{rs}}$ data in figures $49 C$ and $D$ provide a lower limit for $\mathrm{T}_{\mathrm{r}}$ at a given elevation in the mountains. As explained above, the discharge temperatures provide an upper 
Table 13. Water table temperature and mountain ground-water-discharge temperature measurements.

[bgs, below ground surface]

\begin{tabular}{|c|c|c|c|c|c|c|c|c|}
\hline \multirow[b]{2}{*}{ Site name } & \multirow[b]{2}{*}{ Source } & \multicolumn{2}{|c|}{ Location $^{1}$} & \multirow{2}{*}{$\begin{array}{c}\text { Surface } \\
\text { elevation } \\
(\mathrm{m})\end{array}$} & \multirow{2}{*}{$\begin{array}{c}\text { Depth of } \\
\text { measurement } \\
\text { (m bgs) }\end{array}$} & \multirow[b]{2}{*}{$\begin{array}{c}\text { Measurement } \\
\text { type }\end{array}$} & \multirow[b]{2}{*}{ Date } & \multirow[b]{2}{*}{$\begin{array}{c}\mathrm{T} \\
\left({ }^{\circ} \mathrm{C}\right)\end{array}$} \\
\hline & & $\begin{array}{c}\text { Easting } \\
\text { (m) }\end{array}$ & $\begin{array}{l}\text { Northing } \\
\text { (m) }\end{array}$ & & & & & \\
\hline DT5A & Reiter and others, 1976 & 382531 & 3965023 & 2177 & 377 & Water table & $1976^{3}$ & 18.7 \\
\hline G5A & Welenco, 1998 & 388635 & 3975431 & 1955 & 175 & Water table & $1998^{3}$ & 18.3 \\
\hline LA6 & Purtyman, 1976 & 394053 & 3970766 & 1759 & 37 & Water table & $1976^{3}$ & 19.9 \\
\hline SF2B & This study & 395434 & 3965883 & 1683 & 53 & Water table & $06 / 21 / 05$ & 17.0 \\
\hline SF6A & This study & 398635 & 3961265 & 1819 & 40 & Water table & $06 / 21 / 05$ & 16.0 \\
\hline SF River A & This study & 403248 & 3944370 & 1940 & 65 & Water table & $06 / 22 / 05$ & 15.0 \\
\hline Fairgrounds A & This study & 409839 & 3944303 & 2028 & 64 & Water table & $06 / 20 / 05$ & 13.8 \\
\hline Archery 1A & This study & 413195 & 3953775 & 2194 & 152 & Water table & 09/07/05 & 14.6 \\
\hline SF1A & This study & 412884 & 3946763 & 2099 & 36 & Water table & $09 / 07 / 05$ & 13.1 \\
\hline MWA & This study & 413576 & 3949625 & 2100 & 9 & Perched water table & $06 / 24 / 05$ & 13.5 \\
\hline MWB & This study & 413626 & 3949626 & 2102 & 8 & Perched water table & $06 / 30 / 05$ & 13.1 \\
\hline MWB & This study & 413626 & 3949626 & 2102 & 9 & Perched water table & 08/08/05 & 13.7 \\
\hline Chimayo MDWCA \#3 & This study & 416669 & 3982136 & 1884 & 9 & Water table & $09 / 08 / 05$ & 14.3 \\
\hline Alto MW4 & This study & 413274 & 3949466 & 2080 & 30 & Above water table & $06 / 24 / 05$ & 13.6 \\
\hline PNM 05-14 & This study & 413021 & 3948299 & 2097 & 27 & Above water table & 07/01/05 & 13.1 \\
\hline Black Canyon Camp Ground & This study & 424185 & 3953871 & 2538 & 27 & Above water table & 09/09/05 & 8.8 \\
\hline Pajarito Ski Area & This study & 374170 & 3973116 & 2838 & 110 & Discharge_Well & $10 / 06 / 04$ & 7.4 \\
\hline Ski Santa Fe & This study & 428219 & 3960881 & 3240 & 37 & Discharge-Well & $10 / 08 / 04$ & 4.3 \\
\hline Santa Barbara Camp Ground & This study & 445029 & 3993644 & 2732 & 44 & Discharge-Well & 09/08/05 & 7.3 \\
\hline Black Canyon Camp Ground & This study & 424099 & 3953888 & 2531 & 13 & Discharge-Well & $10 / 06 / 04$ & 8.5 \\
\hline PC Spring & This study & 375196 & 3970525 & 2689 & 0 & Discharge-_ Spring & $06 / 29 / 05$ & 6.4 \\
\hline Water Canyon Gallery Spring & This study & 376108 & 3967328 & 2449 & 0 & Discharge-Spring & $10 / 05 / 04$ & 11.5 \\
\hline Duran Spring & This study & 457256 & 3998574 & 2712 & 0 & Discharge-Spring & $09 / 08 / 05$ & 7.1 \\
\hline Aztec Spring & This study & 420015 & 3951255 & 2333 & 0 & Discharge-Spring & $10 / 06 / 04$ & 11.5 \\
\hline Aztec Spring & This study & 420015 & 3951255 & 2333 & 0 & Discharge-Spring & 09/09/05 & 11.7 \\
\hline Beck,s Spring & This study & 427222 & 3957104 & 3168 & 0 & Discharge-Spring & $09 / 06 / 05$ & 3.3 \\
\hline
\end{tabular}

${ }^{1}$ Coordinates $=$ UTM, NAD27, Zone 13S.

${ }^{2}$ For well dishcharge measurements, depth of measurement $=$ mid-screen depth.

${ }^{3}$ Date is approximate. 
limit to $\mathrm{T}_{\mathrm{g}}$. Water table temperatures (thus $\mathrm{T}_{\mathrm{r}}$ ) would only exceed $\mathrm{T}_{\mathrm{g}}$ if water table depths were consistently $>100 \mathrm{~m} \mathrm{bgs}$, which appears unlikely given available water-level data. The discharge temperatures thus provide an upper limit on $\mathrm{T}_{\mathrm{r}}$ at a given elevation in the mountains. Together, the mountain discharge temperatures and $\mathrm{T}_{\mathrm{rs}}$ values define a solution zone containing possible $\mathrm{H}_{\mathrm{r}}-\mathrm{T}_{\mathrm{r}}$ pairs for MBR (figs. $49 E$ and $F$ ).

The water table temperature trendline defines possible $\mathrm{H}_{\mathrm{r}}-\mathrm{T}_{\mathrm{r}}$ pairs for BFR (figs. $49 E$ and $F$ ). The immediate rise in possible $\mathrm{T}_{\mathrm{r}}$ values on the west side at the mountain block/plateau transition is due to the large drop in the water table at this transition. Sample WMWB-01 was collected from a monitoring well located within about $10 \mathrm{~m}$ of the Santa Fe River screened from 5 to $9 \mathrm{~m}$ bgs in a perched zone. The water level in the well tracks closely with river flow, consistent with the perched zone being hydraulically well connected to the river. Existing information indicates that the Santa Fe River is losing water along the reach where the well is located (McAda and Wasiolek, 1988). Therefore, the sample is considered the most likely of any in the data to contain a large fraction of stream-loss water. The sample was collected to address the concern that stream loss during high flow caused by spring snowmelt and/or large rain events in the mountains might result in incomplete gas re-equilibration during infiltration. If stream water infiltrates rapidly as a coherent slug of cool water, incomplete gas re-equilibration during its descent to the regional water table might result in the stream-loss water having a $\mathrm{T}_{\mathrm{r}}$ cooler than the regional water table temperature. The regional water table temperature is $13^{\circ}-14 \mathrm{C}^{\circ}$ on the east side of the basin near the mountain front, and sample WMWB-01 has a $\mathrm{T}_{\mathrm{rs}}$ of $14.4^{\circ} \mathrm{C}$ (fig. 49A). This is consistent with the assumption that stream loss has about the same $\mathrm{T}_{\mathrm{r}}$ as the water table temperature near the mountain front. The water table depth near the mountain front in the Southeast zone is generally $>30 \mathrm{~m}$ bgs, making the scenario in which water traverses the entire unsaturated zone without sufficient air contact to allow gas re-equilibration seem unlikely. Nonetheless, the assumption of unsaturated-zone gas equilibration is fundamental to the method of using noble gases to distinguish MBR from BFR, and more samples similar to WMWB-01 should be collected in future studies to fortify the method. Attempts made in this study to find and sample other wells screened at or above the water table near the mountain front unfortunately were unsuccessful.

Because many of the sampled wells in the basin-fill do not have short screens, the complete solution zone must also include mixtures between MBR and BFR. Complete solution zones for the east and west sides are shown as the gray area in figures $49 E$ and $F$. The boundaries for the solution zone for the west side of the basin remain somewhat uncertain, and more data clearly are needed. However, this uncertainty is balanced by the dramatic contrast between the $T_{r}$ of MBR and BFR. The fact that the $T_{r}$ of MBR is $>6^{\circ} \mathrm{C}$ cooler means that derived $T_{r}$ values from plateau wells should clearly reflect the presence of MBR in the regional aquifer on the plateau, if present, regardless of the precise relationship between $\mathrm{H}_{\mathrm{r}}$ and $\mathrm{T}_{\mathrm{r}}$ in the mountain block and on the plateau.

\section{Recharge Parameters for Holocene Samples}

The recharge parameters $\mathrm{T}_{\text {rmin }}, \mathrm{T}_{\text {rmax }}, \mathrm{T}_{\text {rav }}, \mathrm{H}_{\text {rmin }}, \mathrm{H}_{\text {rmax }}$, $\mathrm{H}_{\mathrm{rav}}$, and $\mathrm{X}_{\min }$ (see table 1 and the section entitled "Methods" for definitions of all recharge parameters) were computed for Holocene samples using the $\mathrm{H}_{\mathrm{r}}-\mathrm{T}_{\mathrm{r}}$ relationships derived for the eastern and western sides of the basin (figs. $49 E$ and $F$, table 11). It is assumed that the climate in the Española Basin has been similar to the current climate throughout the Holocene. Samples were considered of Holocene age if they had adjusted ages $<10,000 \mathrm{yr}$ and maximum ages $<15,000 \mathrm{yr}$. If the Holocene samples are mixtures of both Holocene and Pleistocene water, the Pleistocene fraction is probably small because nearly all Holocene samples have adjusted ages of $<5,000 \mathrm{yr}$ and maximum ages of $<10,000 \mathrm{yr}$. Carbon isotope data were not collected in this study from wells R1, R9, and PNM5, and from Spring 4C. However, samples from wells R1, R9, and from Spring 4C are considered Holocene age here because Longmire and others (2007) present unadjusted ages of 3,134 yr, 10,817 yr, and 3,531 yr, respectively, for samples from these locations. The sample from well PNM5 is also considered Holocene age because adjusted ages from all neighboring wells are $<2,000 \mathrm{yr}$ (fig. 43). $\mathrm{T}_{\text {rmin }}, \mathrm{T}_{\text {rmax }}, \mathrm{H}_{\text {rmin }}$, $\mathrm{H}_{\text {rmax }}$, and $\mathrm{X}_{\text {min }}$ were not computed for samples WMWB-01 and WLAOB-01, because they are from wells screened in perched zones in the basin-fill and almost certainly contain all locally recharged water. The recharge parameters were also not computed for WCHIM2-01, WDEV-01, and WBELL-01, because these samples were collected from wells in which water levels are close (within $10 \mathrm{~m}$ ) to that in an adjacent river. Such conditions introduce the possibility that stream loss from the nearby river may not fully re-equilibrate to the local water table temperature, compromising the ability of the method to distinguish MBR from BFR. $\mathrm{T}_{\text {rmin }}, \mathrm{T}_{\text {rmax }}$, and $\mathrm{X}_{\min }$ were not computed for samples from mountain-block locations, because these samples obviously contain all MBR. For mountain-block samples, $\mathrm{H}_{\mathrm{rmin}}=\mathrm{H}_{\mathrm{rs}}$, and $\mathrm{H}_{\mathrm{rmax}}$ is the top of the local watershed in which the sample point is located.

Figure 50 shows an example of how recharge parameters ( $\mathrm{T}_{\text {rmin }}, \mathrm{T}_{\mathrm{rmax}}$, and so forth) were derived for a Holocene sample using the local $\mathrm{H}_{\mathrm{r}}-\mathrm{T}_{\mathrm{r}}$ relationship. Measured noble gas concentrations in a sample were used to define a sample line as explained in the "Methods" section. The left end of the sample line is the point $\left(\mathrm{H}_{\mathrm{rs}}, \mathrm{T}_{\mathrm{rs}}\right)$. The right end of the sample line is determined by assuming $\mathrm{H}_{\mathrm{r}}=3,600 \mathrm{~m}$. The lower left (dashed) boundary of the solution zone (shaded gray) cannot extend to elevations below $\mathrm{H}_{\mathrm{rs}}$, because that would imply that some of the water in the well might have recharged at an elevation lower than the well. $\mathrm{H}_{\mathrm{rmin}}$ and $\mathrm{T}_{\mathrm{rmax}}$ are defined by the point where the sample line intersects the lower-left boundary of the solution zone, and $\mathrm{H}_{\mathrm{rmax}}$ and $\mathrm{T}_{\mathrm{rmin}}$ are defined by the point where the sample line intersects the upper-right boundary of the solution zone (fig. 50A). $\mathrm{X}_{\min }$ is determined by assuming that the sample is a bi-modal mixture of BFR and MBR end-members, both with the coolest possible $\mathrm{T}_{\mathrm{r}}$ values (fig. 50B). For the east side of the basin, the BFR and MBR end-members were assigned 

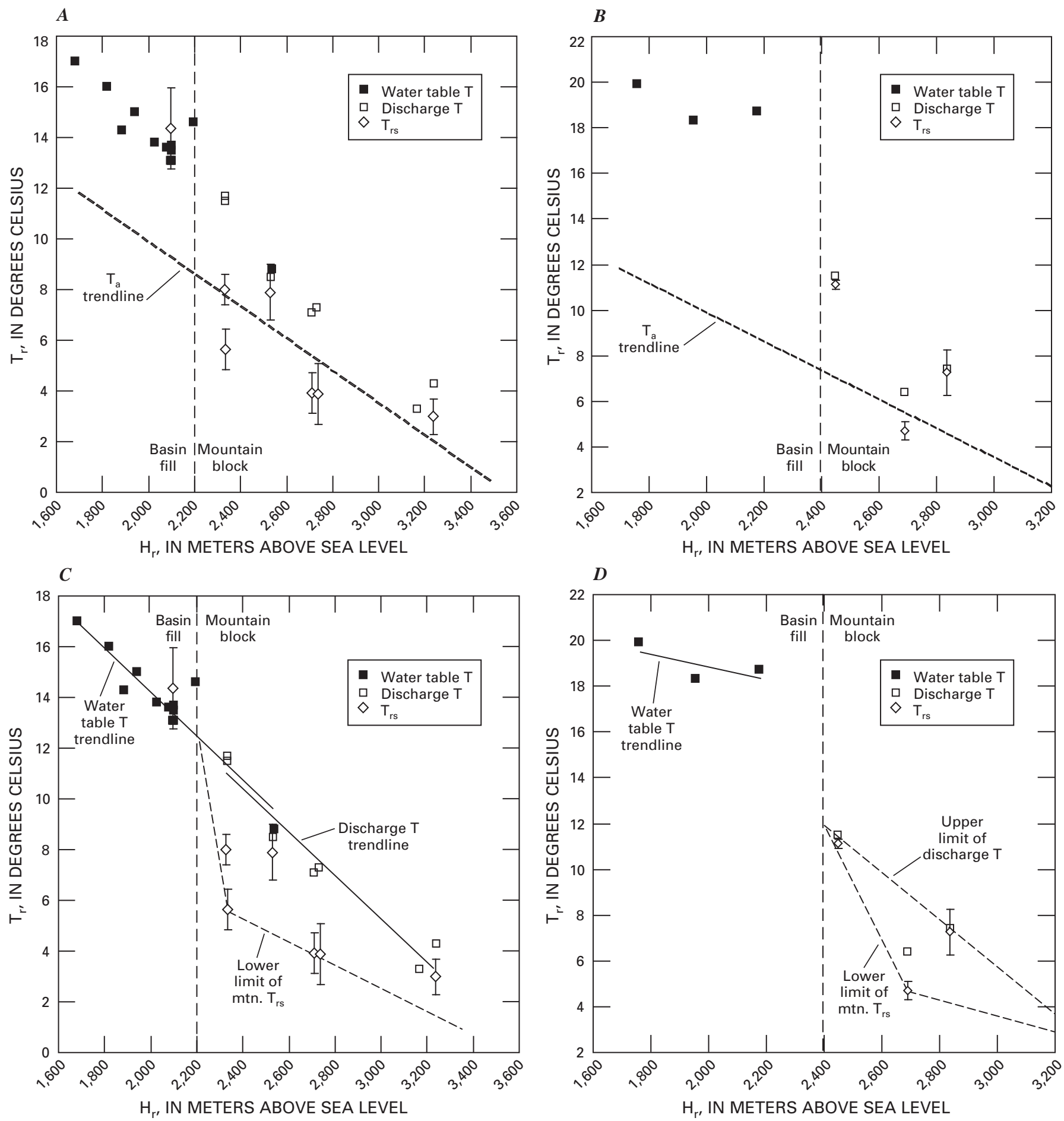

Figure 49. Derivation of $\mathrm{H}_{r}-T_{r}$ relationships for the east side $(A, C, E)$ and west side $(B, D, F)$ of the Española Basin. All temperatures (T) and standard recharge temperatures $\left(\mathrm{T}_{\mathrm{rs}}\right)$ are plotted versus the ground surface elevation at the sample location.

$\mathrm{T}_{\mathrm{r}}$ values of $13^{\circ} \mathrm{C}$ and $3^{\circ} \mathrm{C}$, respectively, because these are the lowest temperature/ $\mathrm{T}_{\mathrm{r}}$ values in the basin-fill and mountain block, respectively, that were used to define the east-side solution zone (fig. 49A). Next, the BFR and MBR end-members are assumed to have the highest and lowest possible $\mathrm{H}_{\mathrm{r}}$ values, respectively, these being 2,150 masl for BFR (just below the mountain front, as demanded if $\mathrm{T}_{\mathrm{r}}=13^{\circ} \mathrm{C}$ ) and 2,920 masl for MBR (lowest possible $\mathrm{H}_{\mathrm{r}}$ if $\mathrm{T}_{\mathrm{r}}=3^{\circ} \mathrm{C}$ ). $\mathrm{X}_{\min }$ is then determined from the point of intersection between the mixing line for the two end-members and the sample line; $\mathrm{X}_{\min }$ is the distance of the intersection point from the BFR end-member divided by the total distance between the BFR and MBR end-members (fig. 50B). To calculate $\mathrm{X}_{\min }$ for west-side samples, BFR and MBR end-members having $\mathrm{T}_{\mathrm{r}}$ values of $18^{\circ} \mathrm{C}$ and $4.5^{\circ} \mathrm{C}$, respectively, and $\mathrm{H}_{\mathrm{r}}$ values of 2,350 masl and 2,690 masl, respectively, were used. 

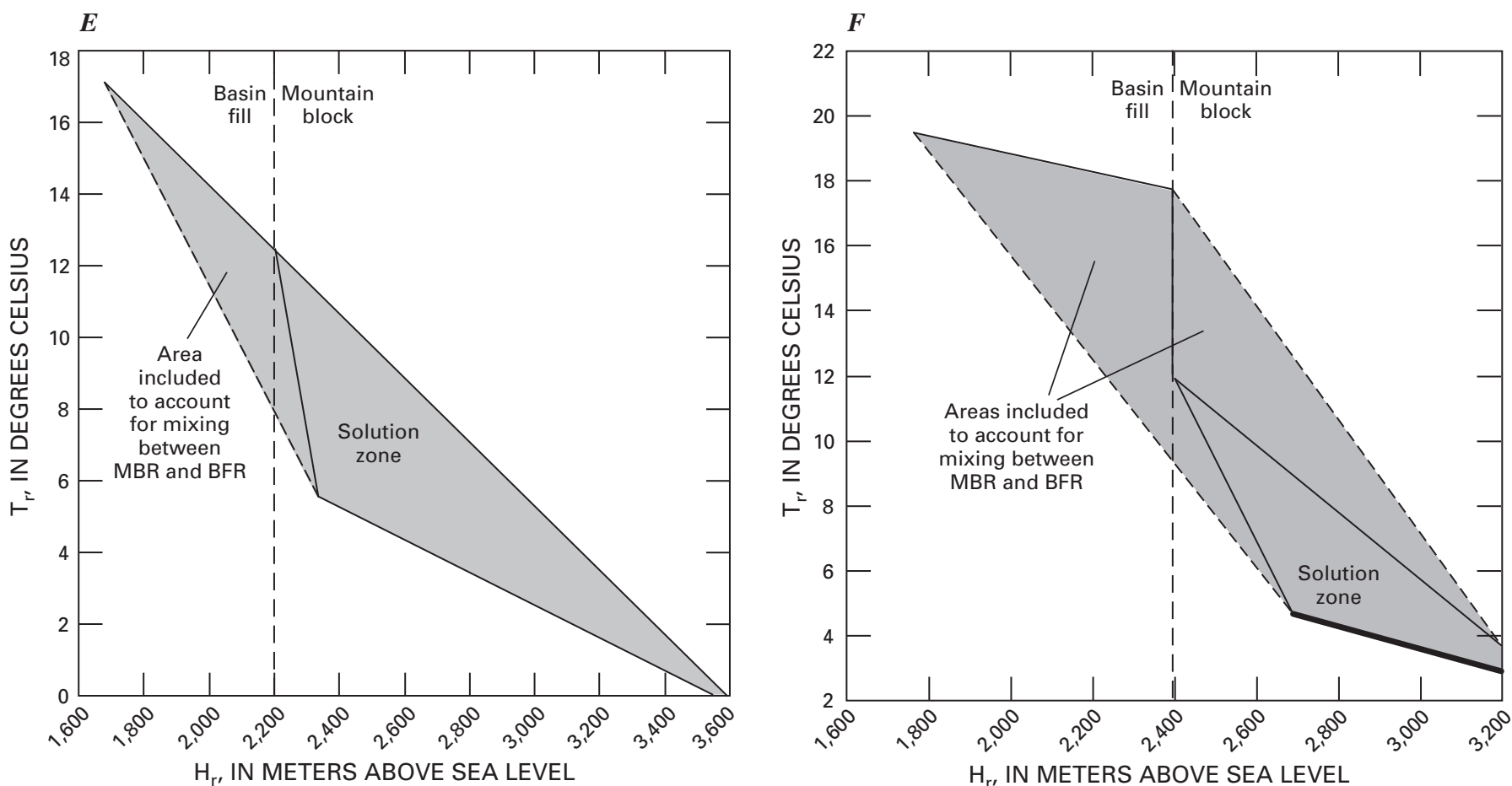

Figure 49-Continued. Derivation of $\mathrm{H}_{r}-\mathrm{T}_{\mathrm{r}}$ relationships for the east side $(A, C, E)$ and west side $(B, D, F)$ of the Española Basin. All temperatures $(T)$ and standard recharge temperatures $\left(\mathrm{T}_{\mathrm{rs}}\right)$ are plotted versus the ground surface elevation at the sample location.

Figures 51,52, 53, and 54 show the distribution of $\mathrm{T}_{\mathrm{rmax}}$, $\mathrm{T}_{\text {rav }}, \mathrm{H}_{\mathrm{rav}}$, and $\mathrm{X}_{\text {min }}$, respectively, in the basin-fill. In the Pajarito Plateau area, 4 of 6 samples (WR1-01, WR2-01, WR4-01, and WR9-01) have $\mathrm{T}_{\text {rav }}$ values of $18^{\circ}-23^{\circ} \mathrm{C}$, which is equal to or warmer than measured water table temperatures on the plateau $\left(18^{\circ}-20^{\circ} \mathrm{C}\right)$. They have $\mathrm{H}_{\text {rav }}$ values of $2,170-2,280$ masl,

\section{A}

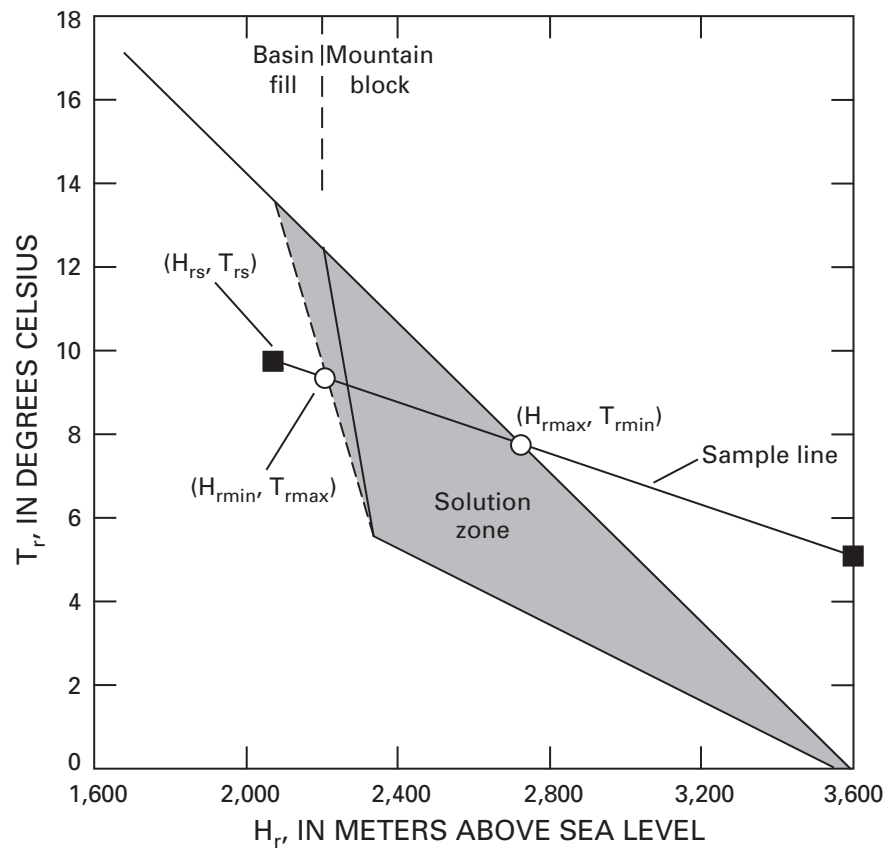

below the mountain front elevation of 2,400 masl. These four samples therefore contain at most a very small component of MBR. Though they are only four samples, they are sufficiently spread out to suggest that ground water in the upper $30 \mathrm{~m}$ of the saturated zone across much of plateau typically contains little MBR. In contrast, samples WR18-01 and S4C-01 have

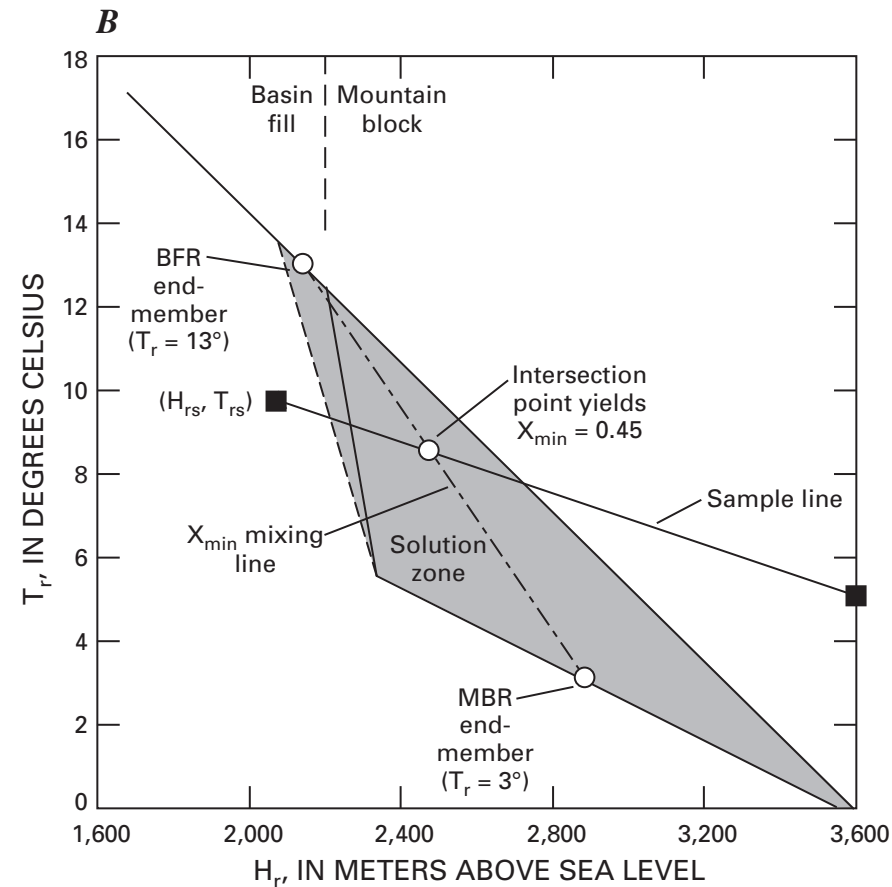

Figure 50. Example of how recharge parameters were derived for Holocene samples using the local $H_{r}-T_{r}$ relationship. See table 1 for explanation of terms. (A) Derivation of $\mathrm{T}_{\mathrm{rmax}^{\prime}} \mathrm{T}_{\mathrm{rmin}} \mathrm{H}_{\mathrm{rmax}}$ and $\mathrm{H}_{\mathrm{rmin}}$. $(B)$ Derivation of $\mathrm{X}_{\text {min }}$. 

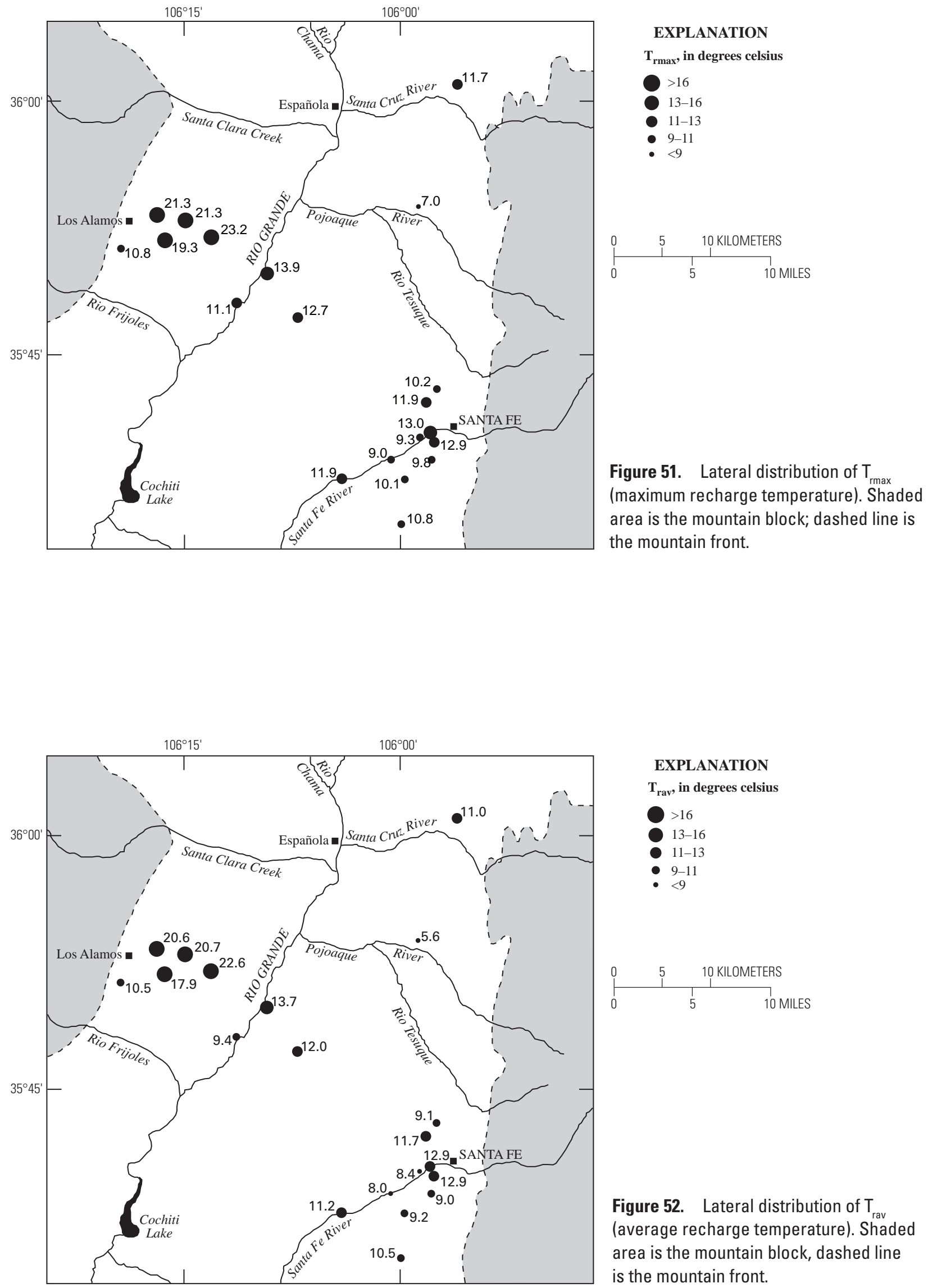

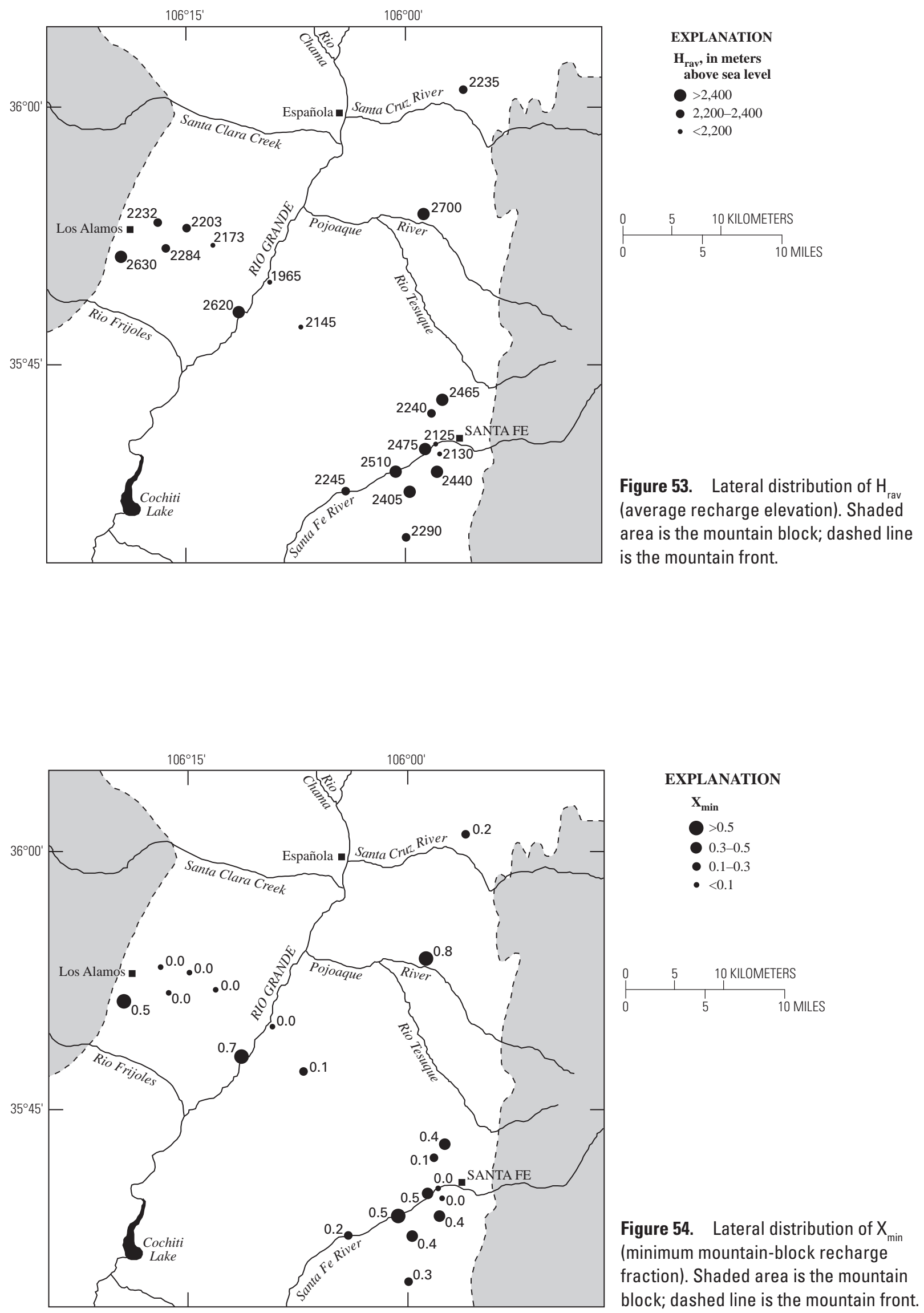
$\mathrm{T}_{\text {rmax }}$ values well below $18^{\circ} \mathrm{C}, \mathrm{H}_{\text {rav }}$ values $>2,400$ masl, and $\mathrm{X}_{\min }$ values of 0.5 and 0.7 . Both samples therefore apparently contain a large component of MBR. Of the sampled wells, $\mathrm{R} 18$ is located closest to the mountain front (within $5 \mathrm{~km}$ ). Sample WR18-01 thus suggests that the upper $30 \mathrm{~m}$ of the saturated zone on the plateau may have a large component of MBR close to the mountain front, up-gradient of where much of the BFR in the form of stream loss occurs. As discussed in the section "Standard Recharge Parameters," the amount of MBR in sample S4C-01 is questionable because it is possible that the spring is fed by a perched aquifer instead of, or in addition to, the regional aquifer.

In the Southeast zone, $\mathrm{T}_{\mathrm{rmax}}$ values are $9.0-13.9^{\circ} \mathrm{C}$. Ten of 12 samples have $\mathrm{T}_{\text {rmax }}$ values $<13^{\circ} \mathrm{C}$, the lowest measured water table temperature in the basin-fill near the mountain front. These samples apparently contain some amount of MBR. $\mathrm{H}_{\text {rav }}$ values are 1,965-2,510 masl, and 8 of 12 samples have $\mathrm{H}_{\text {rav }}$ values greater than the mountain front elevation of 2,200 masl. $X_{\min }$ values are $0.0-0.5,7$ of 12 samples having $X_{\min }$ values $>0.2$. Together, these derived recharge parameters indicate that ground water in much of the Southeast zone contains a significant fraction of MBR, commonly 20-50 percent or more. The four samples with the warmest $\mathrm{T}_{\text {rmax }}$ values are from piezometers SF2 and SF6 $\left(13.9^{\circ} \mathrm{C}\right.$ and $12.7^{\circ} \mathrm{C}$, respectively) located in lower Cañada Ancha, and from City of Santa Fe public supply wells TOR and PNM5 $\left(13.0^{\circ} \mathrm{C}\right.$ and $\left.12.9^{\circ} \mathrm{C}\right)$ located in the city. These relatively warm $\mathrm{T}_{\operatorname{rmax}}$ values are consistent with either all the sampled water recharging just below the mountain front, or the sampled water being a mixture of MBR and water recharged locally as stream loss in Cañada Ancha.

Recharge parameters $\left(\mathrm{T}_{\text {rmin }}, \mathrm{T}_{\text {rmax }}\right.$, and so forth) could only be determined with confidence for two samples in the Northeast zone (WCHIM1-01 and WBYN-01). The other samples are either too old or are from wells with water tables too close to adjacent river levels. These two samples have $\mathrm{T}_{\text {rmax }}$ values $<13^{\circ} \mathrm{C}, \mathrm{H}_{\text {rav }}$ values $>2,200$ masl, and $\mathrm{X}_{\min }$ values $>0.2$. This suggests that Northeast zone water commonly contains a significant fraction of MBR, like Southeast zone water. However, the relative contribution of MBR is more uncertain in the Northeast zone than in the Southeast; in addition to there being only two samples, the depth of the water table in the basin-fill near the mountain front is far less certain due to poor well coverage. It is therefore possible that the fundamental assumption that dissolved gases in stream loss occurring on the basin floor fully re-equilibrate to basin-fill water table temperatures may be erroneous.

\section{Helium and Tritium}

Table 14 lists measured concentrations of $\mathrm{He}, \mathrm{R} / \mathrm{R}_{\mathrm{a}}$, and ${ }^{3} \mathrm{H}$, along with all modeled $\mathrm{He}$ components and apparent ${ }^{3} \mathrm{H} /{ }^{3} \mathrm{He}$ ages. Definitions and explanation of He terms are provided in table 1 and in the section entitled "Methods." Measured ${ }^{3} \mathrm{H}$ concentrations in replicate sample pairs
SYOUNG-01/SYOUNG-01R and WSM-02/WSM-02R do not differ by more than twice the $1-\sigma$ analytical uncertainties listed in the section entitled "Sample Collection and Analysis," as expected.

\section{Terrigenic Helium}

The solubility and excess air components of $\mathrm{He}\left(\mathrm{He}_{\text {sol }}\right.$ and $\mathrm{He}_{\text {ea }}$, respectively) were computed using values of $\mathrm{T}_{\text {rav }}{ }^{\text {sol }}$ $A_{e}$, and $F$ derived from measured concentrations of $\mathrm{N}_{2}$, Ne, Ar, Kr, and Xe assuming that $\mathrm{H}_{\mathrm{r}}=\mathrm{H}_{\text {rav }}$ (table 11). $\mathrm{H}_{\mathrm{rav}}$ is a best estimate of the true $\mathrm{H}_{\mathrm{r}}$ value. For Holocene samples for which $\mathrm{H}_{\text {rmin }}$ and $\mathrm{H}_{\text {rmax }}$ were determined, $\mathrm{H}_{\mathrm{rav}}$ is the average of these two parameters. For the remainder of the Holocene samples, $\mathrm{H}_{\mathrm{rav}}$ was assumed to equal $\mathrm{H}_{\mathrm{rs}}$. For Pleistocene samples, $\mathrm{H}_{\mathrm{rav}}$ was computed using assumed local Pleistocene $\mathrm{H}_{\mathrm{r}}-\mathrm{T}_{\mathrm{r}}$ relationships having the same solution zones as the Holocene local $\mathrm{H}_{\mathrm{r}}-\mathrm{T}_{\mathrm{r}}$ relationships (figs. $49 E$ and $F$ ), but shifted downward $5^{\circ} \mathrm{C}$ in response to $\mathrm{T}_{\mathrm{a}}$ being about $5^{\circ} \mathrm{C}$ cooler during the Pleistocene (Phillips and others, 1986; Stute and others, 1992). This is a tenuous assumption, but it arguably provides the best estimate possible for $\mathrm{He}_{\text {sol }}$ and $\mathrm{He}_{\text {ea }}$. Note that the accuracy of $\mathrm{He}_{\mathrm{sol}}$ and $\mathrm{He}_{\mathrm{ea}}$ is unimportant for most Pleistocene samples anyway because (a) the samples are too old for calculating ${ }^{3} \mathrm{H} /{ }^{\beta} \mathrm{He}$ ages, and (b) the calculated $\mathrm{He}_{\text {terr }}$, the component of primary interest, is insensitive to $\mathrm{He}_{\mathrm{sol}}$ and $\mathrm{He}_{\mathrm{ea}}$ because it is considerably larger than these other components.

$\mathrm{He}_{\text {terr }}$ was computed by subtracting $\mathrm{He}_{\text {sol }}$ and $\mathrm{He}_{\mathrm{ea}}$ from the measured He concentration. $\Delta \mathrm{He}_{\text {terr }}$ is $\mathrm{He}_{\text {terr }}$ expressed as a percentage of $\mathrm{He}_{\text {sol }}$. Figure 55 shows the lateral distribution of $\Delta \mathrm{He}_{\text {terr }}$, and figure 56 shows the vertical distribution of $\Delta \mathrm{He}_{\text {terr }}$ in Southeast zone piezometers. In general, $\mathrm{He}_{\text {terr }}$ is higher in the Northeast and West zones and lower in the Southeast zone. Samples from the nested piezometers suggest that $\mathrm{He}_{\text {terr }}$ generally increases with depth in the Southeast zone. Adjusted ages are on average older in the Northeast zone than in the Southeast zone (fig. 43) and increase with depth in the Southeast zone (fig. 44). This suggests that $\mathrm{He}_{\text {terr }}$ concentrations might be controlled primarily by residence time. However, figure 57 shows only a weak correlation between $\Delta \mathrm{He}_{\text {terr }}$ and adjusted age, indicating that $\mathrm{He}_{\text {terr }}$ concentrations are controlled by other factors as well. $\mathrm{He}_{\text {terr }}$ might also be influenced by variations in the $U$ content of either the aquifer solids within the Tesuque Formation or the basement rock underlying the Tesuque Formation. Figure 58 shows that U concentrations in ground water are generally higher in the Northeast zone than in the Southeast and West zones. McQuillan and others (2005) also report elevated $\mathrm{U}$ concentrations in ground water in the Northeast zone, attributing these to small rollfront $\mathrm{U}$ deposits in the Tesuque Formation. However, figure 59 shows only a weak correlation between $\Delta \mathrm{He}_{\text {terr }}$ and $\mathrm{U}$ concentration in water samples. Furthermore, $\Delta \mathrm{He}_{\text {terr }}$ values are generally high in the West zone, but $\mathrm{U}$ concentrations are low. $\mathrm{He}_{\text {terr }}$ 
might also be influenced by faults that pierce the basement rocks, which could provide preferred pathways for $\mathrm{He}_{\text {ter }}$ produced in the basement to migrate upward into overlying aquifers. The frequency of mapped faults is generally greater in the Northeast and West zones than in the Southeast zone (Sweeney and others, 2002), perhaps indicating a greater likelihood of basement-piercing faults in the Northeast and West zones. In short, $\mathrm{He}_{\text {terr }}$ concentrations in the Española Basin are probably controlled by multiple mechanisms, and any application of $\mathrm{He}_{\text {terr }}$ as an age tracer in the basin would require considerably more data.

\section{Apparent ${ }^{3} \mathrm{H} /{ }^{3} \mathrm{He}$ Ages}

Figure 60 shows the ${ }^{3} \mathrm{H}$ distribution. ${ }^{3} \mathrm{H}$ was measured for 33 samples, including those most likely to contain modern water based on their position in the flow system and ${ }^{14} \mathrm{C}$ data. A few apparently older samples were also included to confirm that they were free of modern water. Samples with ${ }^{3} \mathrm{H}$ concentrations $>1$ TU probably contain a nontrivial fraction of modern water. Such samples are mostly located in the mountains and, sporadically, near rivers. This pattern is consistent with the adjusted radiocarbon age distribution and with recharge occurring in these locations. ${ }^{3} \mathrm{H}$ concentrations in the basin-fill in the Southeast zone are all $<1 \mathrm{TU}$, even adjacent to the Santa Fe River. This suggests that stream loss either occurs close (within about $3 \mathrm{~km}$ ) to the mountain front or, if it occurs farther out (and makes up a significant component of recharge), stream-loss water takes tens of years to traverse the unsaturated zone in this area. Two samples on the Pajarito Plateau, WR4-01 and WR9-01, have ${ }^{3} \mathrm{H}$ concentrations $>1 \mathrm{TU}$, consistent with stream loss occurring away from the mountain front. However, samples from wells R4 and R9 have unadjusted radiocarbon ages of 8,000 and 11,000 yr, respectively (Longmire and others, 2007), suggesting that they are mixtures of water recharged closer to the mountain front (major component) and water recharged locally with a relatively high ${ }^{3} \mathrm{H}$ concentration (minor component). Longmire and others (2007) report that LANL released effluents into surface water drainages with ${ }^{3} \mathrm{H}$ concentrations of thousands of TU. A small fraction of such effluent water in an otherwise ${ }^{3} \mathrm{H}$-free sample could result in the ${ }^{3} \mathrm{H}$ concentrations observed in samples WR4-01 and WR9-01.

Apparent ${ }^{3} \mathrm{H} /{ }^{3} \mathrm{He}$ ages were computed for samples with ${ }^{3} \mathrm{H}$ concentrations $>1$ TU. These samples can be divided into low $\mathrm{He}_{\text {terr }}$ and high $\mathrm{He}_{\text {terr }}$ samples; the former have $\Delta \mathrm{He}_{\text {terr }}$ values $<100$ percent, and the latter have $\Delta \mathrm{He}_{\text {terr }}$ values $>100$ percent. For low $\mathrm{He}_{\text {terr }}$ samples, $\mathrm{R}_{\text {terr }}$ was assumed to be that of crustal He, $2.77 \times 10^{-8}$ (Mamyrin and Tolstikhin, 1984). This is a standard approach because usually $\mathrm{H}_{\text {terr }}$ is composed almost entirely of crustal He. The actual value of $\mathrm{R}_{\text {terr }}$ may be substantially higher in the Española Basin (see following discussion regarding $\mathrm{R}_{\text {terr }} / \mathrm{R}_{\mathrm{a}}$ ), but this uncertainty in $\mathrm{R}_{\text {terr }}$ has only a minor influence on the appar- ent ages (up to $\pm 3 \mathrm{yr}$ ). Apparent ages for low $\mathrm{He}_{\text {terr }}$ samples therefore reliably represent the age of the modern component in the sample.

Sample initial ${ }^{3} \mathrm{H}$ concentrations (measured ${ }^{3} \mathrm{H}+$ calculated ${ }^{3} \mathrm{He}_{\text {trit }}$ ) were compared to the precipitation ${ }^{3} \mathrm{H}$ record by plotting apparent recharge year versus initial ${ }^{3} \mathrm{H}$ concentration (fig. 61). This is a check commonly performed as part of the ${ }^{3} \mathrm{H} /{ }^{3} \mathrm{He}$ method to determine if samples contain a large fraction of pre-bomb water (see Manning and others, 2005). The precipitation ${ }^{3} \mathrm{H}$ record in figure 61 is for Albuquerque, N. Mex. (International Atomic Energy Agency, 2006), and is the nearest relatively complete record available. The Albuquerque record was extended backward from 1963 to 1953 by correlation with the Ottawa precipitation ${ }^{3} \mathrm{H}$ record using methods explained in Manning and others (2005). Samples containing a large fraction of pre-bomb water will plot below the precipitation ${ }^{3} \mathrm{H}$ record in figure 61. Four low $\mathrm{He}_{\text {terr }}$ samples are of this type, SWCG-01, WMWB44-01, S4C-01, and WBELL-01. Three of the low $\mathrm{He}_{\text {terr }}$ samples, WSSF-01, WSBCG-01, and WLAOB-01, plot clearly above the precipitation ${ }^{3} \mathrm{H}$ record. These samples may do so for multiple reasons, including (a) ${ }^{3} \mathrm{H}$ contamination (in atmospheric deposition or in ground water), (b) naturally higher precipitation ${ }^{3} \mathrm{H}$ concentrations at higher elevations (all three samples should contain all mountain precipitation), (c) mixing of modern waters of different ages, or (d) long unsaturated-zone residence times (Manning and others, 2005).

The high $\mathrm{He}_{\text {terr }}$ samples include WR4-01 and WR9-01 from the West zone, and WCHIM2-01, WDEV-01, and WBYN-01 from the Northeast zone. Apparent age is poorly constrained for these samples because it is sensitive to $\mathrm{R}_{\text {terr }}$, which is uncertain for high ${ }^{3} \mathrm{H}$ samples $\left({ }^{3} \mathrm{H}>1 \mathrm{TU}\right)$, and can vary dramatically in the Española Basin based on low ${ }^{3} \mathrm{H}$ samples $\left({ }^{3} \mathrm{H}<1 \mathrm{TU}\right.$, see following discussion of $\mathrm{R}_{\text {terr }} / \mathrm{R}_{\mathrm{a}}$ ). However, initial ${ }^{3} \mathrm{H}$ values were used to place limits on $\mathrm{R}_{\text {terr }}$ for the high $\mathrm{He}_{\text {terr }}$ samples, thereby placing limits on apparent age. Two different approaches were used. For the Northeast zone samples, a value of $2.77 \times 10^{-8}$ was initially assumed for $\mathrm{R}_{\text {terr }}$. The resulting sample initial ${ }^{3} \mathrm{H}$ value plotted well above the precipitation ${ }^{3} \mathrm{H}$ record and was clearly implausible (for example, an initial ${ }^{3} \mathrm{H}$ of $252 \mathrm{TU}$ and a recharge year of 1929; fig. 61). $\mathrm{R}_{\text {terr }}$ was then increased until the initial ${ }^{3} \mathrm{H}$ value plotted close to the precipitation ${ }^{3} \mathrm{H}$ record, that is, until the initial ${ }^{3} \mathrm{H}$ concentration decreased sufficiently to be plausible. The resulting apparent age was considered the maximum apparent age (shown on fig. 61), with the minimum apparent age being $0 \mathrm{yr}$.

Adams and others (1995) present precipitation ${ }^{3} \mathrm{H}$ data indicating that precipitation ${ }^{3} \mathrm{H}$ concentrations in the Northeast and Southeast zones were similar to those in Albuquerque between 1990 and 1993, but West zone concentrations were consistently 2-4 times higher during this period, probably due to atmospheric releases from LANL. It is therefore likely that precipitation ${ }^{3} \mathrm{H}$ concentrations in the West zone have been substantially higher than in Albuquerque for the past $50 \mathrm{yr}$, 
Table 14. He and ${ }^{3} \mathrm{H}$ data, modeled He components, and ${ }^{3} \mathrm{H} /{ }^{3} \mathrm{He}$ ages.

$\left[\mathrm{He}_{\mathrm{sol}}\right.$, solubility He component; $\mathrm{He}_{\text {ea, }}$, excess air $\mathrm{He}$ component; $\mathrm{He}_{\mathrm{ter}}$, terrigenic $\mathrm{He}$ component; $\Delta \mathrm{He}_{\mathrm{terr}}$ terrigenic $\mathrm{He}$ component expressed as a percentage of Hesol; $\mathrm{R}$, sample ${ }^{3} \mathrm{He} /{ }^{4} \mathrm{He}$ ratio; $\mathrm{R}_{\mathrm{a}}$, atmospheric ${ }^{3} \mathrm{He} /{ }^{4} \mathrm{He}$ ratio; $\mathrm{R}_{\text {terr }}{ }^{3} \mathrm{He} /{ }^{4} \mathrm{He}$ ratio in $\mathrm{He}_{\text {terr }} ;{ }^{3} \mathrm{He}_{\text {sol }}$, solubility ${ }^{3} \mathrm{He}$ component; ${ }^{3} \mathrm{He}$ ea , excess air ${ }^{3} \mathrm{He}$ component; ${ }^{3} \mathrm{He}$ terr component; $\Delta^{3} \mathrm{He}_{\text {terr }}$, terrigenic ${ }^{3} \mathrm{He}$ component expressed as a percentage of ${ }^{3} \mathrm{He}_{\text {sol }}{ }^{3} \mathrm{He}_{\text {trit }}$ tritiogenic ${ }^{3} \mathrm{He}$ component; initial ${ }^{3} \mathrm{H},{ }^{3} \mathrm{He}$ trit ${ }^{3} \mathrm{H}$; $\mathrm{cm}^{3} \mathrm{STP} / \mathrm{g}$, cubic cm at standard temperature and pressure per gram of water; sol, solubility; TU, tritium units; $\mathrm{U}$, undetermined; NC, not computed; NA, not applicable.

Notes: $1, \mathrm{He}$ components not modeled because gas concentrations unreliable due to air bubble in sample tube; $2, \mathrm{R}_{\mathrm{ter}}$ computed assuming age $>50 \mathrm{yr}$ (based on location), ${ }^{3} \mathrm{H}=0 \mathrm{TU}$, and initial ${ }^{3} \mathrm{H}=5 \mathrm{TU} ; 3$, Gas concentrations uncertain and $\mathrm{R} / \mathrm{R}_{\mathrm{a}}$ not measured due to very high He concentration, so He components modeled assuming $\mathrm{H}_{\mathrm{rav}}=\mathrm{H}_{\mathrm{rs}}$; 4, Apparent age $>50 \mathrm{yr}$ based on ${ }^{3} \mathrm{H}<1 \mathrm{TU} ; 5, \mathrm{R}_{\mathrm{ter}}$ computed assuming initial ${ }^{3} \mathrm{H}=5 \mathrm{TU} ; 6$, Assumed water table depth $=300 \mathrm{~m}$ at $\mathrm{H}_{\mathrm{rvy}} ; 7$, Assumed $\mathrm{R}_{\mathrm{terr}}$ is average of untritiated high-He Pajarito Plateau wells (R1, R2); 8, He components not modeled because gas concentrations unreliable due to ice blockage during extraction; 9, Single apparent age cannot be computed due to high $\mathrm{He}_{\text {terr }}$, and $\mathrm{R}_{\text {terr }}$ is minimum value that yields initial ${ }^{3} \mathrm{H}$ value consistent with Albuquerque precipitation ${ }^{3} \mathrm{H}$ record]

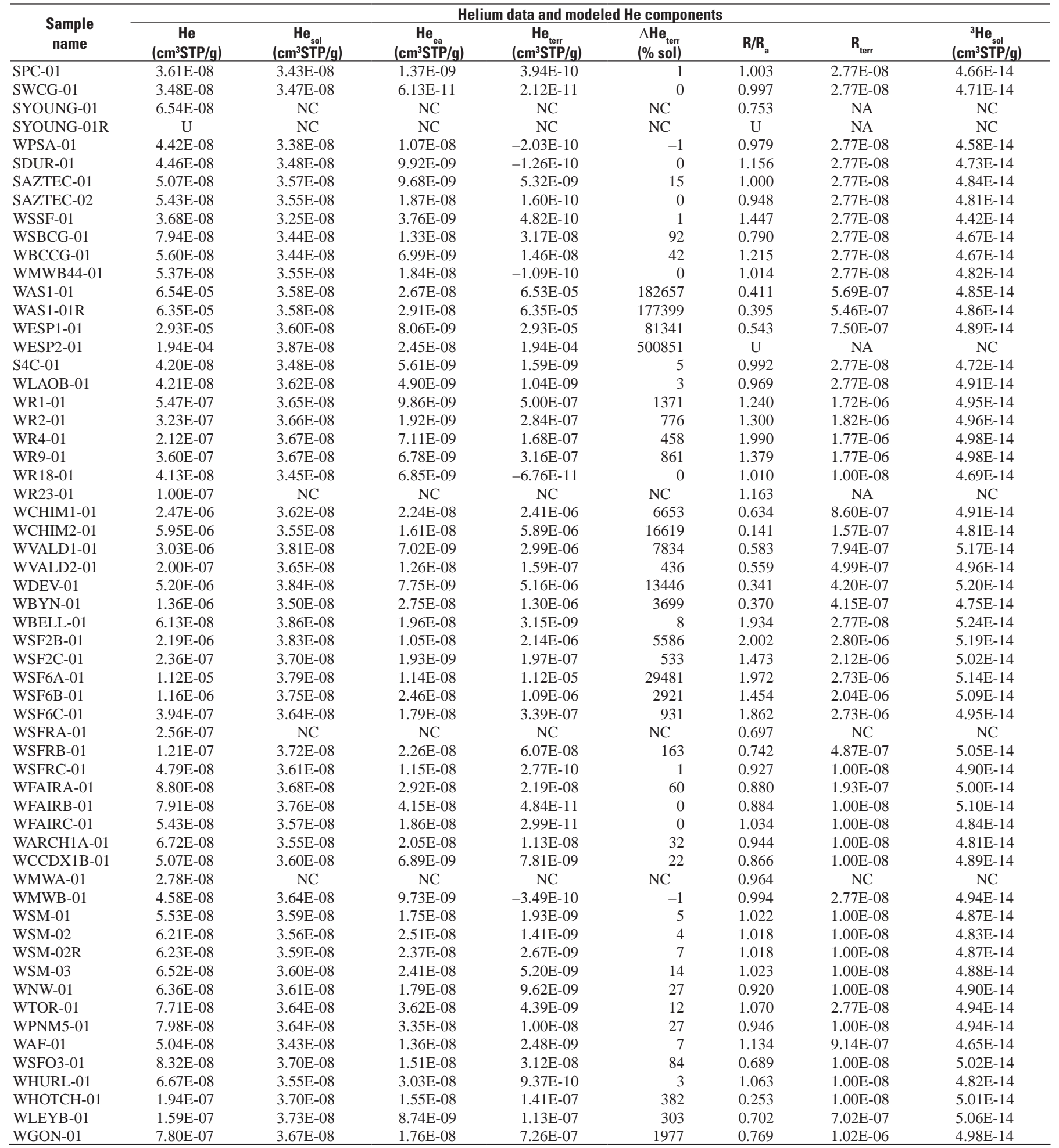


Table 14. He and ${ }^{3} \mathrm{H}$ data, modeled He components, and ${ }^{3} \mathrm{H} /{ }^{3} \mathrm{He}$ ages.-Continued

$\left[\mathrm{He}_{\text {sol }}\right.$, solubility He component; $\mathrm{He}_{\mathrm{ea}}$, excess air $\mathrm{He}$ component; $\mathrm{He}_{\text {terr }}$, terrigenic $\mathrm{He}$ component; $\Delta \mathrm{He}_{\text {terr }}$, terrigenic $\mathrm{He}$ component expressed as a percentage of Hesol; $\mathrm{R}$, sample ${ }^{3} \mathrm{He} /{ }^{4} \mathrm{He}$ ratio; $\mathrm{R}$, atmospheric ${ }^{3} \mathrm{He} /{ }^{4} \mathrm{He}$ ratio; $\mathrm{R}_{\text {terr }}{ }^{3} \mathrm{He} /{ }^{4} \mathrm{He}$ ratio in $\mathrm{He}_{\text {terr }} ;{ }^{3} \mathrm{He}_{\text {sol }}$, solubility ${ }^{3} \mathrm{He}$ component; ${ }^{3} \mathrm{He}_{\text {ea }}$, excess air ${ }^{3} \mathrm{He}$ component; ${ }^{3} \mathrm{He}$ terr , terrigenic ${ }^{3} \mathrm{He}$ component; $\Delta^{3} \mathrm{He}_{\text {terr }}$, terrigenic ${ }^{3} \mathrm{He}$ component expressed as a percentage of ${ }^{3} \mathrm{He}_{\text {sol }} ;{ }^{3} \mathrm{He}_{\text {trit }}$ tritiogenic ${ }^{3} \mathrm{He}$ component; initial ${ }^{3} \mathrm{H},{ }^{3} \mathrm{He}$ trit $+{ }^{3} \mathrm{H} ; \mathrm{cm}^{3} \mathrm{STP} / \mathrm{g}$, cubic cm at standard temperature and pressure per gram of water; sol, solubility; TU, tritium units; $\mathrm{U}$, undetermined; NC, not computed; NA, not applicable.

Notes: 1 , He components not modeled because gas concentrations unreliable due to air bubble in sample tube; $2, \mathrm{R}_{\text {ter }}$ computed assuming age $>50$ yr (based on location), ${ }^{3} \mathrm{H}=0 \mathrm{TU}$, and initial ${ }^{3} \mathrm{H}=5 \mathrm{TU} ; 3$, Gas concentrations uncertain and $\mathrm{R} / \mathrm{R}_{\mathrm{a}}$ not measured due to very high He concentration, so He components modeled assuming $\mathrm{H}_{\mathrm{rav}}=\mathrm{H}_{\mathrm{rs}}$; 4, Apparent age $>50 \mathrm{yr}$ based on ${ }^{3} \mathrm{H}<1 \mathrm{TU} ; 5, \mathrm{R}_{\text {terr }}$ computed assuming initial ${ }^{3} \mathrm{H}=5 \mathrm{TU} ; 6$, Assumed water table depth $=300 \mathrm{~m}$ at $\mathrm{H}_{\mathrm{ray}} ; 7$, Assumed $\mathrm{R}_{\mathrm{terr}}$ is average of untritiated high-He Pajarito Plateau wells (R1, R2); 8, He components not modeled because gas concentrations unreliable due to ice blockage during extraction; 9, Single apparent age cannot be computed due to high $\mathrm{He}_{\text {term }}$, and $\mathrm{R}_{\text {terr }}$ is minimum value that yields initial ${ }^{3} \mathrm{H}$ value consistent with Albuquerque precipitation ${ }^{3} \mathrm{H}$ record]

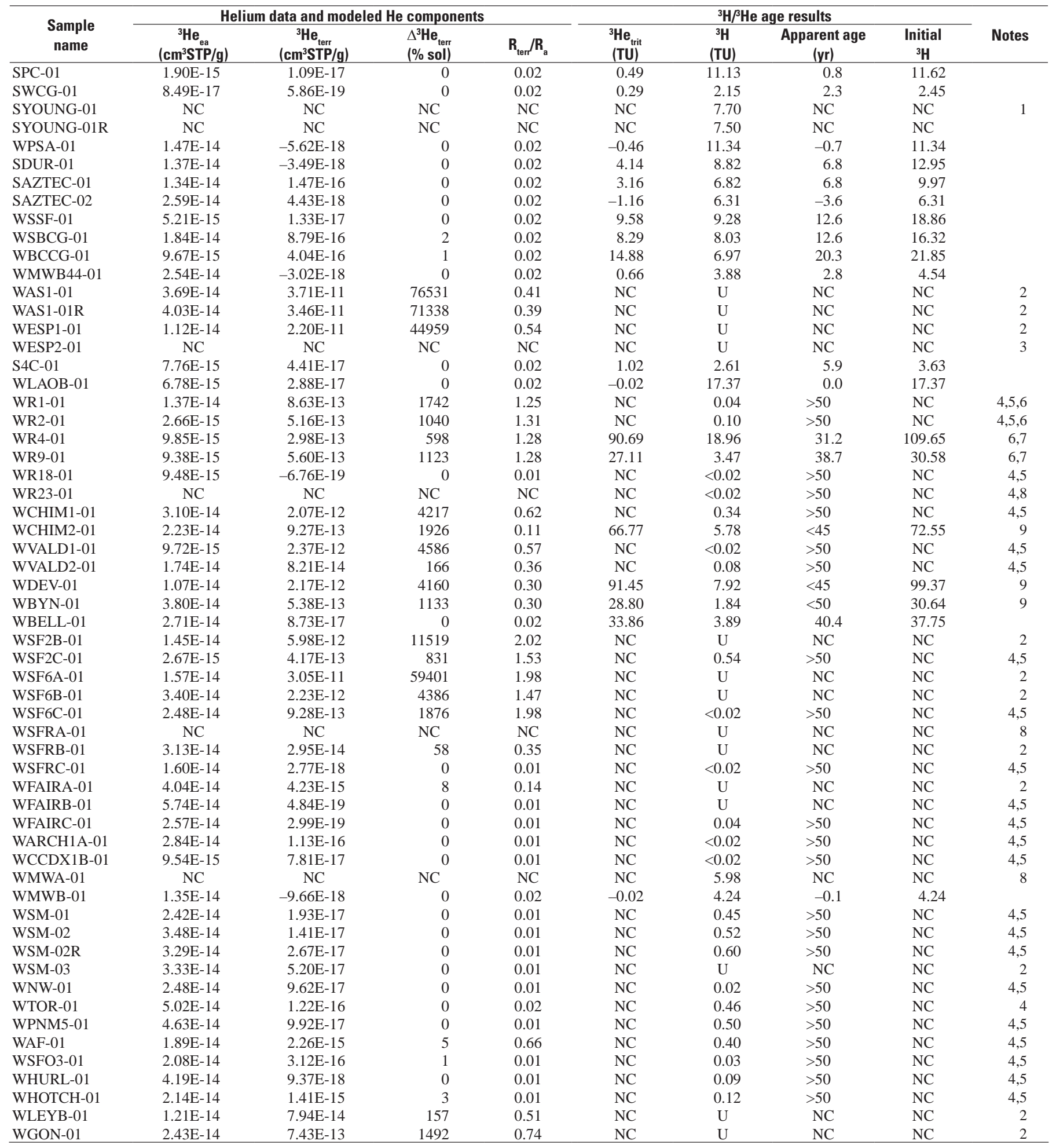



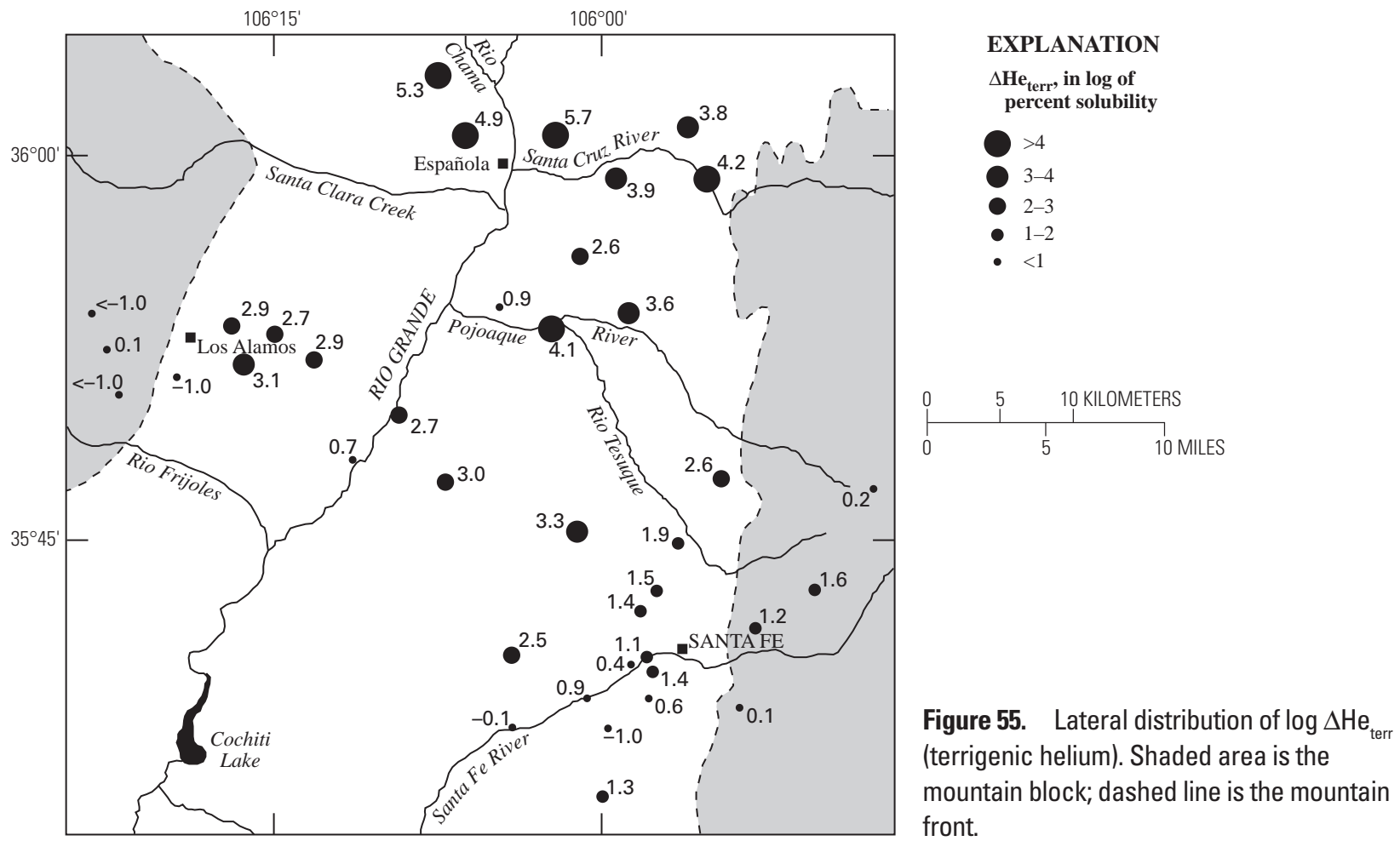

meaning that the Albuquerque precipitation ${ }^{3} \mathrm{H}$ record cannot be used to constrain $\mathrm{R}_{\text {terr }}$ for West zone samples. Samples WR1-01 and WR2-01 are West zone samples having high $\mathrm{He}_{\text {terr }}$, such as WR4-01 and WR9-01, but they contain very little ${ }^{3} \mathrm{H}(<0.1 \mathrm{TU})$. ${ }^{3} \mathrm{H}$ concentrations this low indicate that these samples contain essentially all pre-bomb water and could never have contained ${ }^{3} \mathrm{H}$ released by LANL, ${ }^{3} \mathrm{H}$ produced from open-air testing of nuclear weapons, or ${ }^{3} \mathrm{H}$ derived from any other anthropogenic

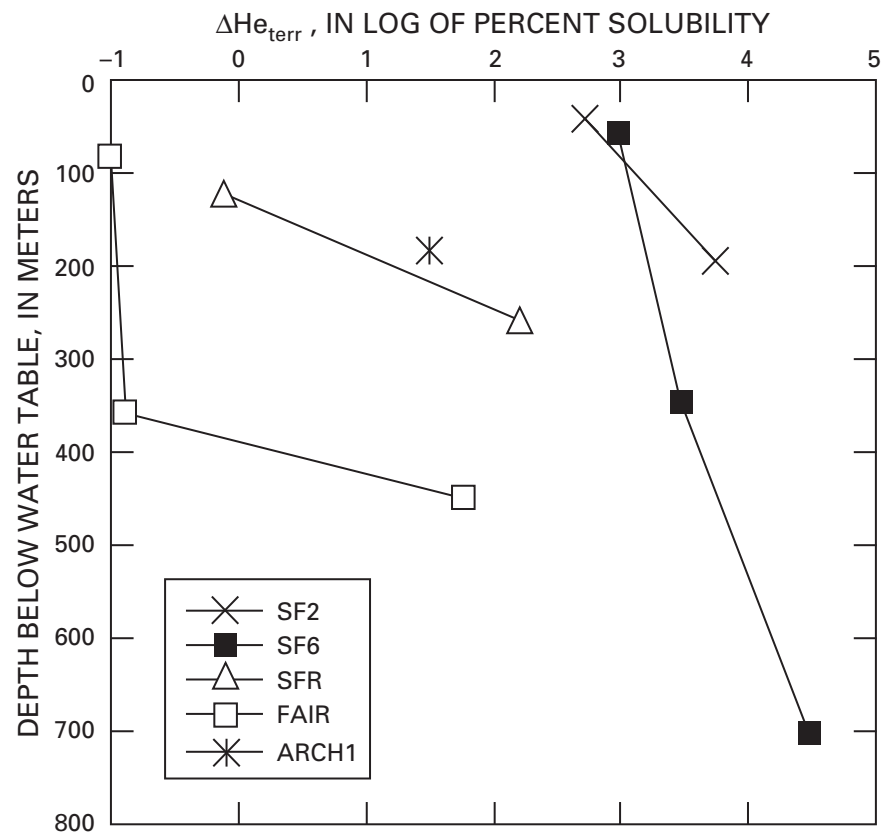

Figure 56. Vertical distribution of $\log \Delta \mathrm{He}_{\text {terr }}$ (terrigenic helium) in nested piezometers. sources. Natural pre-bomb precipitation ${ }^{3} \mathrm{H}$ concentrations in the Española Basin are assumed to be 5 TU based on Roether (1967). Additionally, measured ${ }^{3} \mathrm{H}$ concentrations in samples WMWA-01 and WMWB-01, probably composed solely of recent precipitation, are 6.0 and 4.2 TU, respectively, and prebomb precipitation ${ }^{3} \mathrm{H}$ concentrations should not exceed current levels. Initial ${ }^{3} \mathrm{H}$ values for samples WR1-01 and WR2-01 therefore cannot be significantly greater than $5 \mathrm{TU}$. $\mathrm{R}_{\text {terr }}$ was

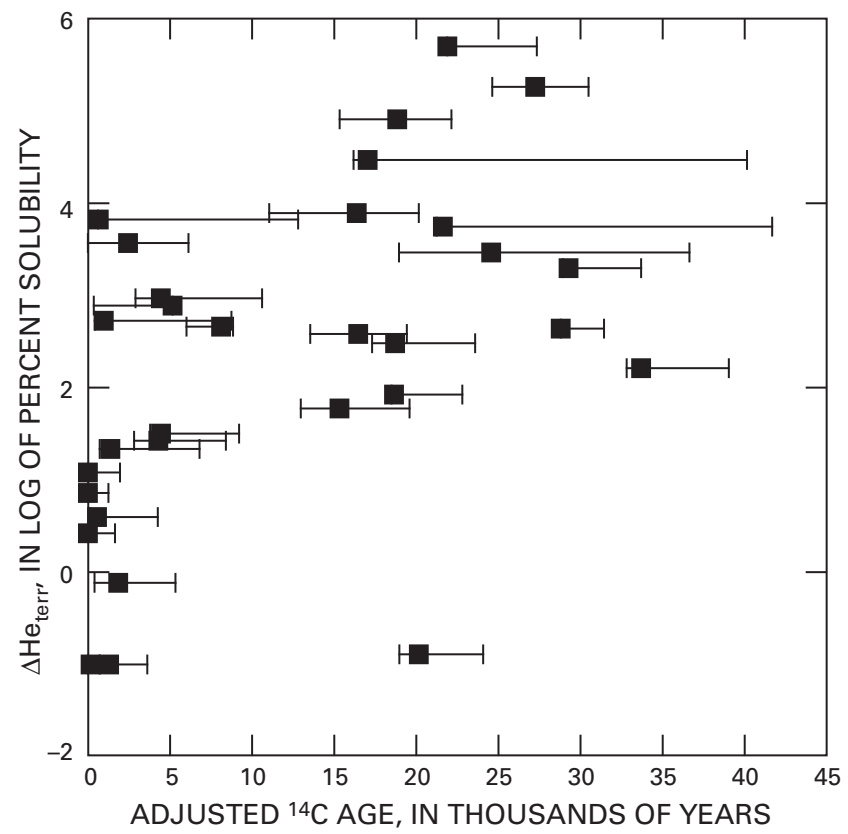

Figure 57. $\log \Delta \mathrm{He}_{\text {terr }}$ (terrigenic helium) versus adjusted ${ }^{14} \mathrm{C}$ age. 


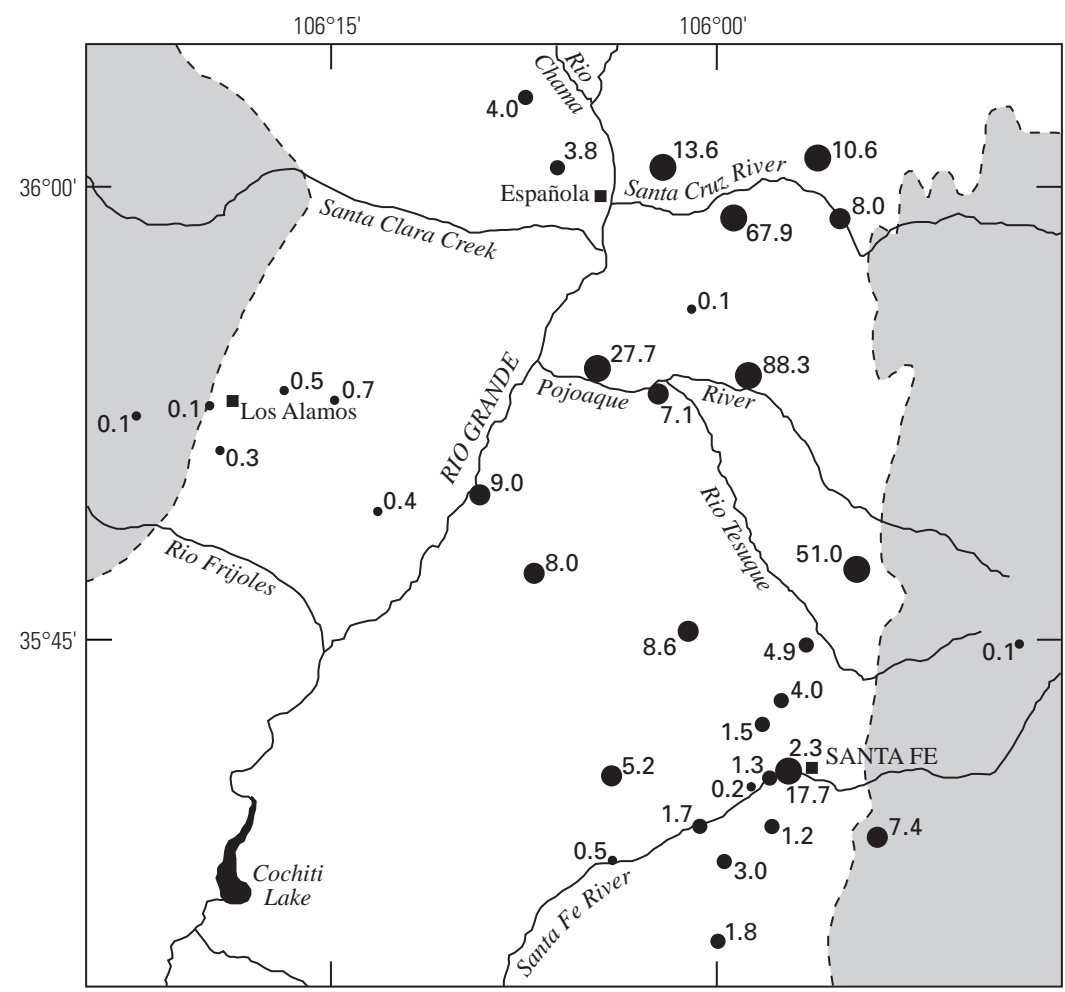

\section{EXPLANATION}

$\mathrm{U}$ concentration, in micrograms per liter

$<1.0$

$1.0-5.0$

- $5.0-10.0$

- $>10.0$

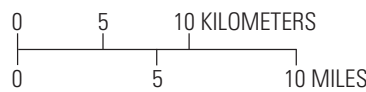

Figure 58. Lateral distribution of $\mathrm{U}$ concentration. Shaded area is the mountain block; dashed line is the mountain front adjusted for samples WR1-01 and WR2-01 until initial ${ }^{3} \mathrm{H}$ values equaled $5 \mathrm{TU}$, yielding $\mathrm{R}_{\text {terr }}$ values of $1.72 \times 10^{-6}$ and $1.82 \times 10^{-6}$, respectively. These values are both very similar and very high, indicating a significant upward flux of mantle $\mathrm{He}$ in the vicinity of wells R1 and R2, and perhaps throughout much of the Pajarito Plateau. Their average value of $1.77 \times 10^{-6}$ serves as a best estimate for $\mathrm{R}_{\text {terr }}$ for samples WR4-01 and WR9-01, given that all four wells are located in the same general area, and was thus used to compute the estimated apparent age and initial ${ }^{3} \mathrm{H}$ values for these samples shown in figure 61 and table 14. It is possible that initial ${ }^{3} \mathrm{H}$ values for samples WR4-01 and WR9-01 were actually considerably higher than those estimated (meaning lower $\mathrm{R}_{\text {terr }}$ values and older apparent ages) because the samples may have initially contained large amounts of ${ }^{3} \mathrm{H}$ produced by LANL. In short, apparent ages for the high $\mathrm{He}_{\text {terr }}$ samples in the West zone are highly uncertain and must be interpreted with caution.

Apparent ${ }^{3} \mathrm{H} /{ }^{3} \mathrm{He}$ ages were not computed for samples with ${ }^{3} \mathrm{H}$ concentrations $<1 \mathrm{TU}$. These samples contain little or no modern water, so computed ages would be highly uncertain. These samples were assigned an apparent age of $>50$ yr. Figure 62 shows the lateral distribution of apparent age. Apparent ages in the mountains are $<50 \mathrm{yr}$, and apparent ages in the basin-fill are generally $>50 \mathrm{yr}$, as expected based on the ${ }^{3} \mathrm{H}$ distribution (fig. 60). In addition to wells WR4 and WR9 discussed above, samples from wells along the Pojoaque River (WBYN, WDEV, and WBELL) and well WCHIM2 near the Santa Cruz River are exceptions having apparent ages of $<50 \mathrm{yr}$. These younger ages in the basin-fill suggest that recharge occurs in these areas, either as stream loss, septic effluent infiltration, or both. Samples from all four of these wells are apparently human impacted (table 5).
Mantle Helium

$\mathrm{R}_{\text {terr }}$ was estimated for samples with ${ }^{3} \mathrm{H}$ concentrations $<1$ TU using the same approach as described above for samples WR1-01 and WR2-01, assuming an initial ${ }^{3} \mathrm{H}$ equal to 5 TU. Samples for which ${ }^{3} \mathrm{H}$ was not measured probably also have ${ }^{3} \mathrm{H}$ concentrations $<1 \mathrm{TU}$ because they were collected either from wells located far from the mountain front (and from rivers other than the Rio Grande) or from the nested piezometers at

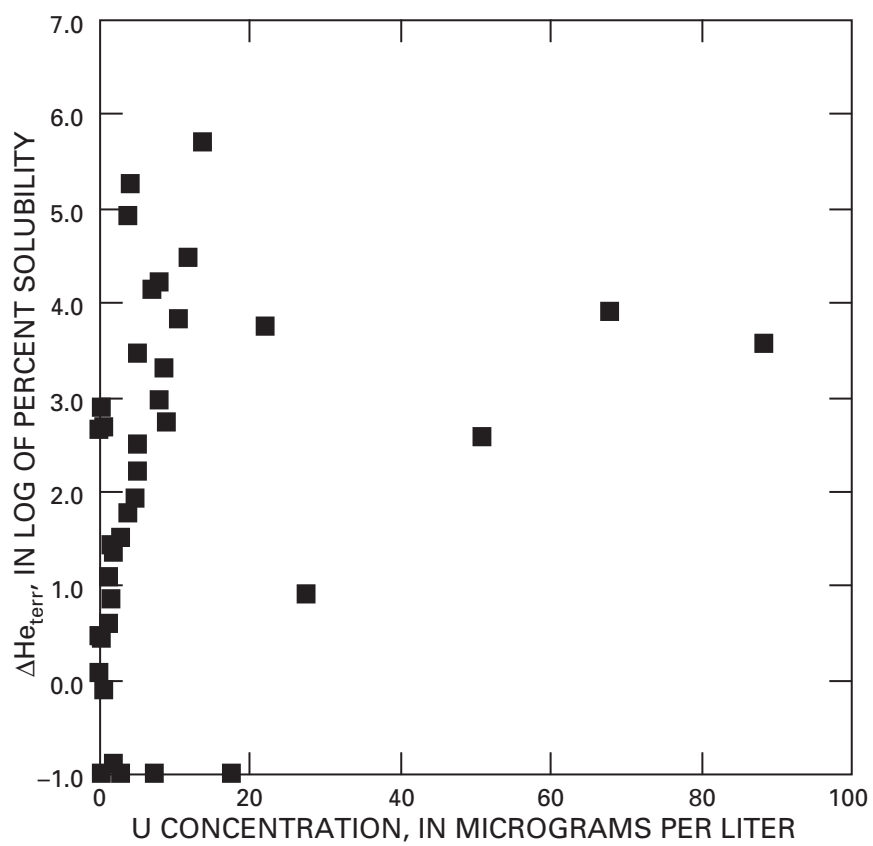

Figure 59. $\log \Delta \mathrm{He}_{\text {terr }}$ (terrigenic helium) versus $\mathrm{U}$ concentration. 


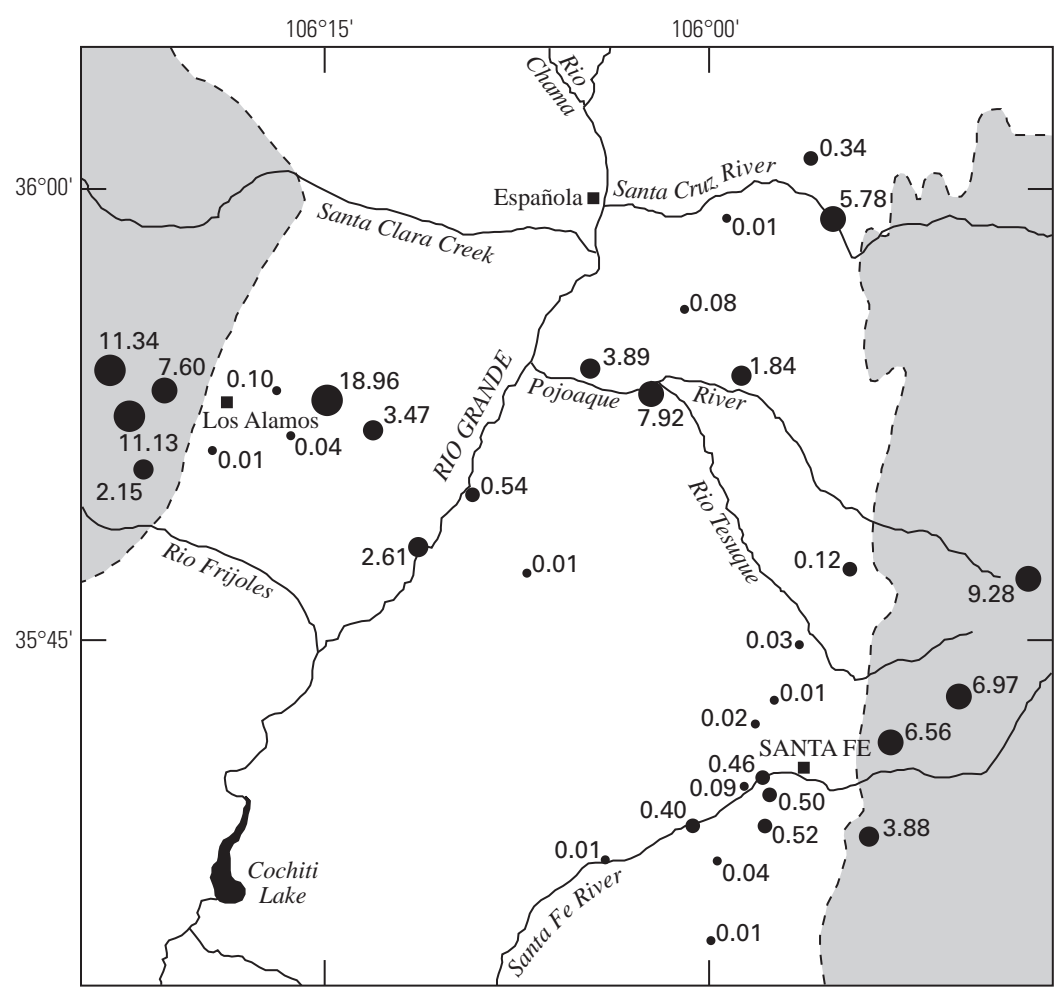

\section{EXPLANATION}

${ }^{3} \mathrm{H}$ concentration, in tritium units

$>10.0$

$5.0-10.0$

$1.0-5.0$

- $0.1-1.0$

- $<0.1$

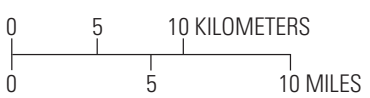

Figure 60. Lateral distribution of ${ }^{3} \mathrm{H}$ concentration. Shaded area is the mountain block; dashed line is the mountain front.

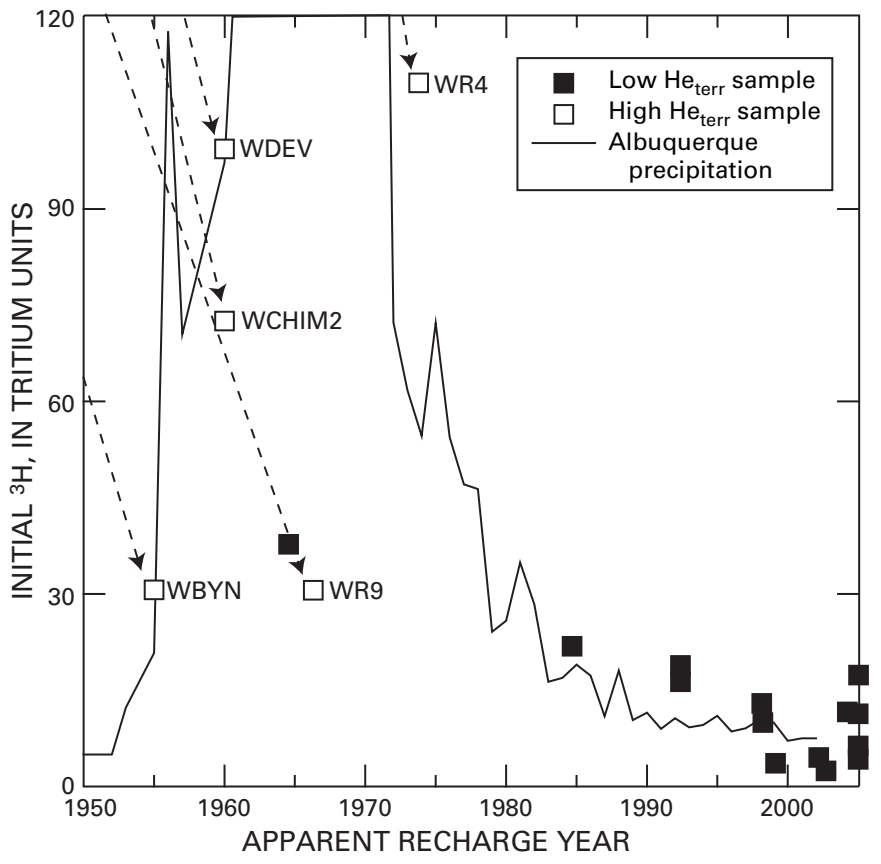

Figure 61. Apparent recharge year (from apparent ${ }^{3} \mathrm{H} /{ }^{3} \mathrm{He}$ age) versus initial ${ }^{3} \mathrm{H}$ (measured ${ }^{3} \mathrm{H}+{ }^{3} \mathrm{H}_{\text {trit }}$ ). Albuquerque precipitation ${ }^{3} \mathrm{H}$ record is also shown. Dashed arrows indicate where high $\mathrm{He}_{\text {ter }}$ (terrigenic helium) samples plotted prior to adjusting $\mathrm{R}_{\text {terr }}\left({ }^{3} \mathrm{He} /{ }^{4} \mathrm{He}\right.$ ratio in $\left.\mathrm{He}_{\text {terr }}\right)$. depths greater than those yielding samples with ${ }^{3} \mathrm{H}$ concentrations $<1$ TU. $\mathrm{R}_{\text {terr }}$ was similarly estimated for these samples, assuming they have a ${ }^{3} \mathrm{H}$ concentration of $0 \mathrm{TU}$ and an initial ${ }^{3} \mathrm{H}$ of 5 TU. Figure 63 shows the lateral distribution of $R_{\text {terr }} / R_{a}$ for samples with $\Delta \mathrm{He}_{\text {terr }}$ values $>100$ percent, these producing the most reliable estimates of $R_{\text {terr }} / R_{a}$. Values of $R_{\text {terr }} / R_{a}$ vary widely, ranging from 0.01 to 1.98 , but most are between 0.3 and 1.98 . These values are well above those typically observed in ground water in continental areas $(\leq 0.2)$, and suggest that most ground water in the Española Basin contains a large component of mantle He. This is not surprising given that the Rio Grande rift is a major active rift zone with recent volcanic activity, and high mantle He fluxes are commonly associated with these features. $\mathrm{R}_{\text {terr }} / \mathrm{R}_{\mathrm{a}}$ values generally increase with proximity to the western border fault system (dominated by the Pajarito fault), which has controlled basin subsidence, and the Quaternary to Miocene volcanics (Jemez Mountains and Cerros del Rio) in the west and southwest portions of the basin (figs. 2 and 63). These features may therefore allow the upward migration of deep mantle fluids. Figure 64 indicates that $\mathrm{R}_{\text {terr }} / \mathrm{R}_{\mathrm{a}}$ values remain high at depth in piezometers SF2 and SF6 (where adjusted radiocarbon ages are $>15,000 \mathrm{yr}$ ), providing further evidence that elevated $\mathrm{R}_{\text {terr }} / \mathrm{R}_{\mathrm{a}}$ values in the Española Basin are due primarily to mantle $\mathrm{He}$, not local atmospheric ${ }^{3} \mathrm{H}$ contamination from LANL. 

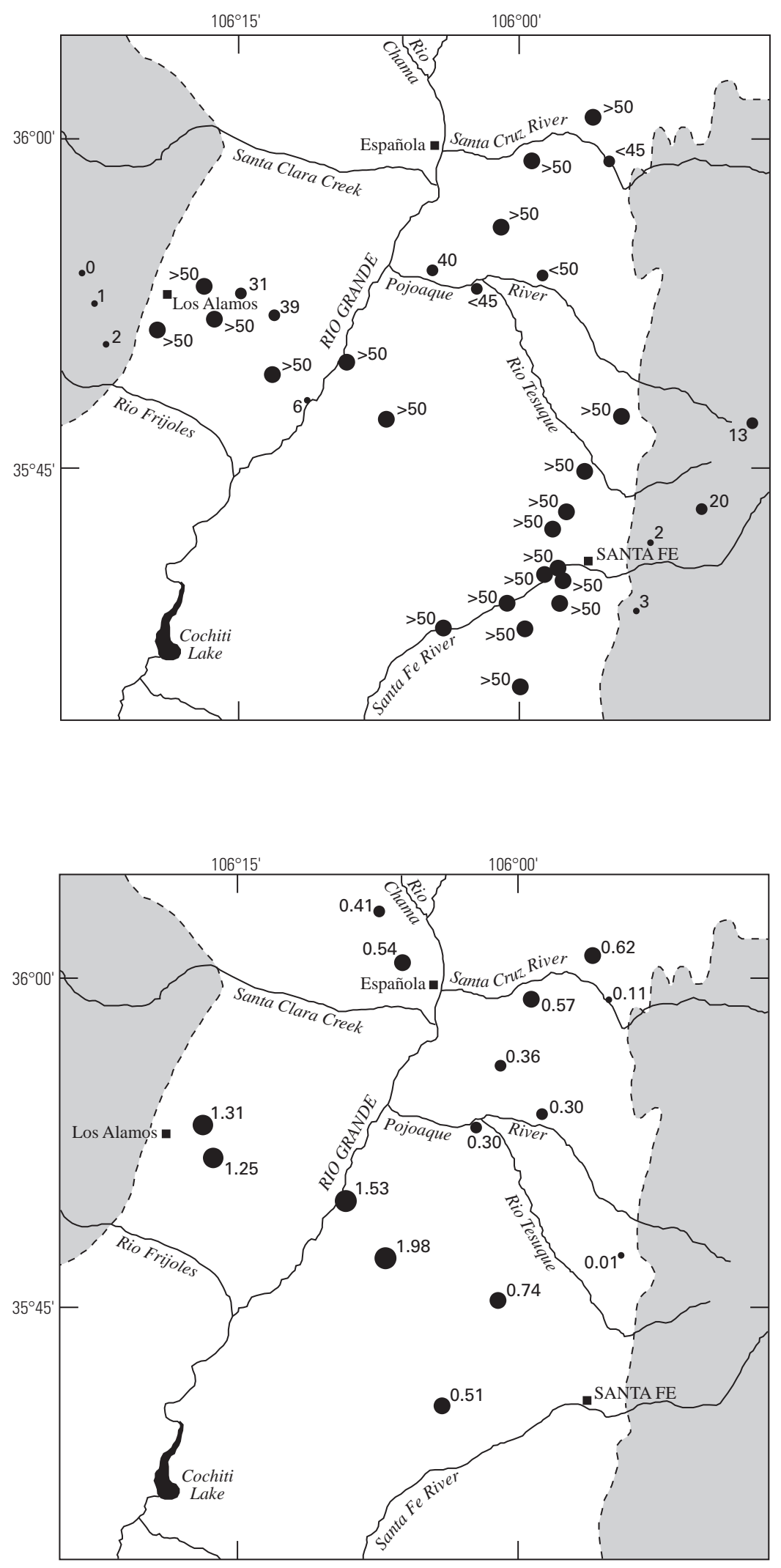

EXPLANATION

Apparent ${ }^{3} \mathrm{H} /{ }^{3} \mathrm{He}$ age,

in years

$>50$

- $10-50$

- $<10$

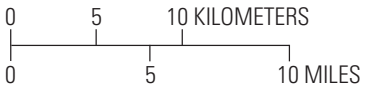

Figure 62. Lateral distribution of apparent ${ }^{3} \mathrm{H} /{ }^{3} \mathrm{He}$ age. Shaded area is the mountain block; dashed line is the mountain front.

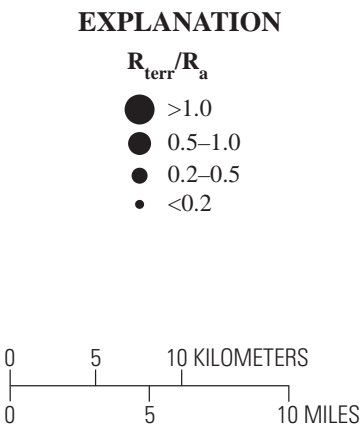

Figure 63. Lateral distribution of $R_{\text {terr }} / R_{a}$. Only high $\mathrm{He}_{\text {terr }}$ samples ( $\Delta \mathrm{He}_{\text {terr }}>100$ percent) are shown. Shaded area is the mountain block; dashed line is the mountain front. $R_{\text {terr, }}$ ${ }^{3} \mathrm{He} /{ }^{4} \mathrm{He}$ ratio in $\mathrm{He}_{\text {terr }} ; \mathrm{R}_{\mathrm{a}^{\prime}}{ }^{3} \mathrm{He} /{ }^{4} \mathrm{He}$ ratio in air; $\mathrm{He}_{\text {terr }}$, terrigenic helium. 


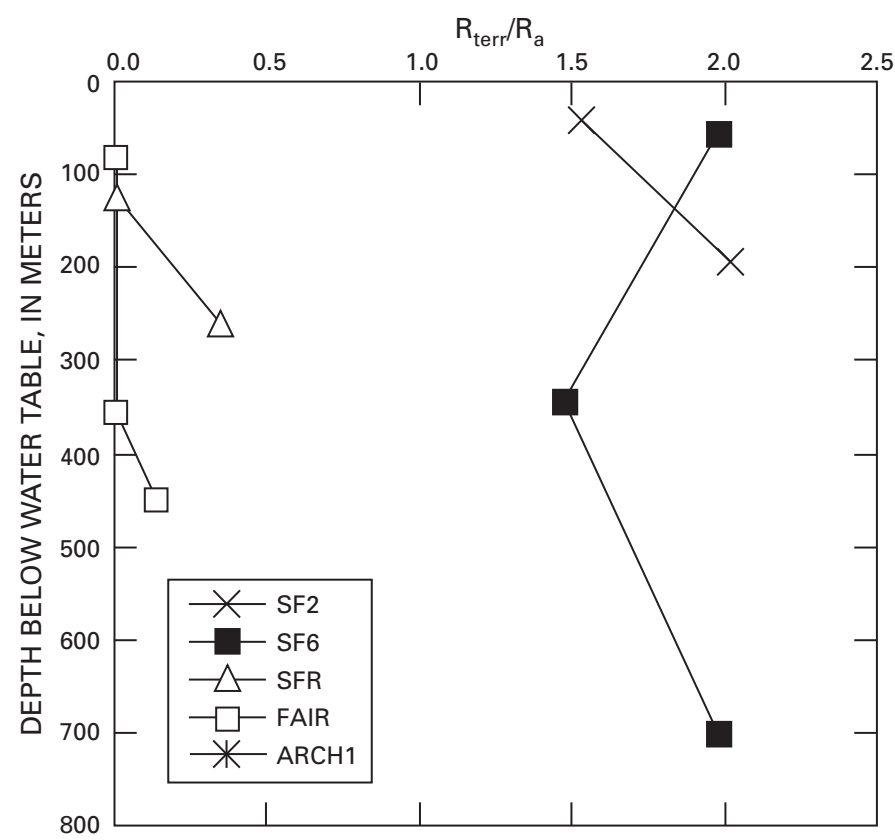

Figure 64. Vertical distribution of $\mathrm{R}_{\text {terr }} / \mathrm{R}_{\mathrm{a}}$ in nested piezometers. $\mathrm{R}_{\text {terr' }}{ }^{3} \mathrm{He} /{ }^{4} \mathrm{He}$ ratio in $\mathrm{He}_{\text {terr' }} ; \mathrm{R}_{\mathrm{a}^{\prime}}{ }^{3} \mathrm{He} /{ }^{4} \mathrm{He}$ ratio in air; $\mathrm{He}_{\text {terr' }}$ terrigenic helium.

\section{Summary of Important Findings}

Ground-water samples were collected from 56 locations throughout the Española Basin, including the adjacent mountains, and analyzed for general chemistry (major ions and trace elements), carbon isotopes $\left(\delta^{13} \mathrm{C}\right.$ and ${ }^{14} \mathrm{C}$ activity) in dissolved inorganic carbon, noble gases ( $\mathrm{He}, \mathrm{Ne}, \mathrm{Ar}, \mathrm{Kr}$, $\mathrm{Xe}$, and ${ }^{3} \mathrm{He} /{ }^{4} \mathrm{He}$ ratio), and tritium. The resulting data reveal a great deal about the recharge, geochemical evolution, flow pathways, and residence time of ground water in the basin. However, the most important results of this study regard the location of ground-water recharge in the basin.

A fundamental question regarding recharge to the Española Basin is, what is the relative magnitude of recharge that occurs in the mountains (mountain-block recharge, or MBR) versus that which occurs in the basin-fill sediments (basin-fill recharge, or BFR)? Existing information is conflicting on the actual importance of MBR in the basin. Modeling studies and mountain-water budget estimates (McAda and Wasiolek, 1988; Wasiolek, 1995; Keating and others, 2003) suggest that MBR is a major recharge component, composing 50 percent or more of recharge throughout most of the basin. However, a chloride mass-balance study performed in the southeastern part of the basin by Anderholm (1994) combined with the apparently low permeability of the crystalline metamorphic rocks composing the Sangre de Cristo Mountains suggest that MBR may be small to negligible, at least on the eastern side of the basin. A potential overestimation of MBR (and thus total recharge) would have major implications for the management of ground-water resources in the basin, particularly decisions regarding sustainable rates of extraction.
Recharge temperatures computed from the noble gas data were used in this study to estimate the minimum fraction of MBR in Holocene age ground water $(<11,550 \mathrm{yr}$ old $)$ in the basin-fill. Minimum MBR fractions in the southeastern part of the basin are commonly $0.2-0.5$ (fig. 54), indicating that MBR composes at least 20-50 percent of recharge throughout most of that area. Minimum MBR fractions in the northeastern part of the basin are $0.2-0.8$, though only two data points exist in this area. The noble gas recharge temperatures are therefore generally consistent with the large MBR fractions on the eastern side of the basin estimated in previous modeling and mountain-water budget studies. Given the low likelihood of deep ground-water circulation in mountain blocks composed of crystalline rock like the Sangre de Cristo Mountains (Manning and Caine, 2007), this MBR probably enters the basin-fill at relatively shallow depths ( $<200 \mathrm{~m} \mathrm{bgs})$ and may be focused near the mouths of mountain-front drainages.

The relative magnitude of BFR on the Pajarito Plateau is important in assessing the susceptibility of the regional aquifer beneath the plateau to contaminants historically released at Los Alamos National Laboratory. Herein, recharge on the plateau is considered BFR and recharge in the Jemez Mountains west of the plateau is considered MBR. The occurrence of elevated ${ }^{3} \mathrm{H}$ concentrations and anthropogenic compounds along with $\delta^{2} \mathrm{H}$ and $\delta^{18} \mathrm{O}$ ratios somewhat heavier than those expected for MBR indicate the presence of BFR in the regional aquifer under the plateau (Collins and others, 2005). Previous studies suggest that this BFR is a minor component of total recharge compared to MBR (see summary in Collins and others, 2005), but the relative magnitude of BFR on the Pajarito Plateau remains uncertain. Noble gas recharge temperatures obtained in this study (fig. 52) indicate that the upper $30 \mathrm{~m}$ of the regional aquifer under much of the Pajarito Plateau typically contains nearly all BFR. The minimum MBR fraction of 0.5 in well R18 (fig. 54), located closest to the mountain front, suggests that water close to the mountain front contains mostly MBR. It is possible that recharge to the regional aquifer is dominantly MBR, but that the sampled wells are screened in an upper layer of locally recharged BFR water that overlies MBR water deeper in the aquifer. It is also possible that BFR occurs largely near the mountain front with relatively little occurring farther out on the plateau where most of the lab facilities are located. More noble gas data would have to be collected from wells more broadly distributed across the plateau and wells screened deeper in the aquifer ( $>30 \mathrm{~m}$ below the water table) to address these hypotheses and effectively evaluate the distribution of BFR under the plateau.

The magnitude of stream loss from the Santa Fe River in comparison to MBR from the mountains east of the city is potentially important in the management of water resources near the City of Santa Fe. The role of stream loss in recharging city-owned production wells adjacent to the river is of particular interest to the city. Adjusted ${ }^{14} \mathrm{C}$ ages generally become older with distance from the Santa Fe River (fig. 43). This suggests that stream loss from the river is indeed recharging the 
aquifer under the river. The chemical composition of ground water in the southeastern part of the basin is also consistent with stream loss occurring from the Santa Fe River; samples collected closest to the river apparently have been impacted by anthropogenic sources (as has the river water), whereas those collected farther from the river apparently have not (fig. 40). Recharge temperatures from the southeastern part of the basin are in general sufficiently cool to suggest that MBR is a major fraction of recharge. However, they are not sufficiently cool to be inconsistent with a substantial BFR fraction. In fact, recharge temperatures from two wells located within the city and close to the river (TOR and PNM5; fig. 52) are sufficiently warm to indicate that they are recharged almost entirely by BFR. Assuming this BFR is stream loss from the river, these recharge temperatures suggest that stream loss locally can be a primary component of recharge to the aquifer near the river. Although stream loss is apparently occurring, ${ }^{3} \mathrm{H}$ concentrations in all wells in the Santa Fe River corridor are $\leq 0.5 \mathrm{TU}$ (fig. 60). These low ${ }^{3} \mathrm{H}$ concentrations suggest that either stream loss takes more than 50 years to infiltrate and flow to city production wells (the likely case for TOR and PNM5), or it flows to the wells more rapidly but is a small fraction of total recharge. In summary, the data in this report indicate that recharge in the form of stream loss from the Santa Fe River is occurring in the vicinity of Santa Fe, but they also suggest that stream-loss recharge rates are low. Sampling on a more detailed spatial scale near the river and the collection of additional data types, particularly from discrete depths below the river, would be required to quantify the rate and distribution of stream loss from the Santa Fe River.

\section{Conclusions}

1. Spatial trends in the chemical and isotopic composition of ground water in the Española Basin allow it to be divided into four hydrochemical zones: West, Southeast, Northeast, and Central Deep. West zone waters have the lowest concentration of all major ions except $\mathrm{Mg}$, indicating the least water-rock interaction. West zone waters also have the lightest $\delta^{13} \mathrm{C}$ values and the highest ${ }^{14} \mathrm{C}$ activities. Southeast zone waters have intermediate concentrations of all major ions except $\mathrm{Ca}$ (highest), intermediate $\delta^{13} \mathrm{C}$ values, and intermediate ${ }^{14} \mathrm{C}$ activities. Locally elevated $\mathrm{Cl}$ concentrations, occurring largely in the Santa Fe area, are probably due to mixing with human-impacted waters. Northeast zone waters have intermediate concentrations of all major ions except $\mathrm{Mg}$ (lowest) and $\mathrm{Cl}$ and $\mathrm{SO}_{4}$ (highest), intermediate $\delta^{13} \mathrm{C}$ values, and intermediate ${ }^{14} \mathrm{C}$ activities. North of the Pojoaque River and east of the Rio Grande, elevated $\mathrm{Cl}$ and $\mathrm{SO}_{4}$ are likely due to mixing with upward leaking brines. Central Deep zone waters have the highest concentration of all major ions except $\mathrm{Ca}, \mathrm{Cl}$, and $\mathrm{SO}_{4}$, indicating the most water-rock interaction, along with the heaviest $\delta^{13} \mathrm{C}$ values and the lowest ${ }^{14} \mathrm{C}$ activities. These waters have probably interacted with mantle-sourced $\mathrm{CO}_{2}$.
2. Temperature profiles and the vertical distribution of adjusted ${ }^{14} \mathrm{C}$ ages in the Southeast zone suggest that ground-water flow rates are substantially higher at depths $<250 \mathrm{~m}$ bgs than at depths $>250 \mathrm{~m}$ bgs. This suggests that a significant decrease in the permeability of the basin-fill occurs at a depth of about $250 \mathrm{~m} \mathrm{bgs}$.

3. Noble gas recharge temperatures indicate that ground water in the Southeast zone contains a significant fraction of mountain-block recharge (MBR), commonly 20-50 percent or more. The same is apparently true for the Northeast zone, though only two data points could be used to evaluate the MBR fraction in this area. Recharge temperatures indicate that the upper $30 \mathrm{~m}$ of the regional aquifer on the Pajarito Plateau commonly contains little or no MBR. This does not rule out significant MBR fractions at greater depths. The large MBR fraction (>0.5) in well R18, located closest to the mountain front, suggests that water deeper in the aquifer may indeed contain more MBR. Noble gas data would have to be collected from wells that are deeper and more broadly distributed in the West zone in order to effectively evaluate the relative contribution of MBR to total recharge in this area.

4. Noble gas recharge temperatures, ${ }^{3} \mathrm{H}$ concentrations, and adjusted ${ }^{14} \mathrm{C}$ ages indicate that basin-floor recharge (BFR) is occurring in the Espanola Basin. Recharge temperatures become warmer farther from the mountain front in many parts of the basin, consistent with BFR. Recharge temperatures are sufficiently warm on the Pajarito Plateau to indicate that water in the upper $30 \mathrm{~m}$ of the saturated zone is nearly all BFR across much of the plateau. Both ${ }^{3} \mathrm{H}$ concentrations and ${ }^{14} \mathrm{C}$ ages indicate younger ground water closer to rivers traversing the east side of the basin (and Cañada Ancha). This age distribution is consistent with BFR occurring as stream-loss and arroyo recharge, and occurring well out into the basin from the mountain front. The fact that all three samples collected from the Pojoaque River corridor have ${ }^{3} \mathrm{H}$ concentrations $>1$ TU means that BFR in this area could be largely septic effluent rather than stream loss. The fact that ${ }^{3} \mathrm{H}$ concentrations in the Santa Fe River corridor are all $<1$ TU suggests that stream loss occurring west of Santa Fe takes more than 50 years to infiltrate and flow to the sampled wells. The occurrence of water with ${ }^{3} \mathrm{H}$ concentrations $>1 \mathrm{TU}$ on the Pajarito Plateau is consistent with BFR occurring on the plateau.

5. Terrigenic $\mathrm{He}\left(\mathrm{He}_{\text {terr }}\right)$ concentrations in ground water are high ( $\log \Delta \mathrm{He}_{\text {terr }}$ of 2 to 5) throughout much of the Española Basin. High $\mathrm{He}_{\text {terr }}$ concentrations are probably caused by in situ production in the Tesuque Formation from locally high concentrations of U-bearing minerals (Northeast zone only), or by upward diffusive/advective transport of crustal-/mantle-sourced He possibly enhanced by basement piercing faults, or by both. The ${ }^{3} \mathrm{He} /{ }^{4} \mathrm{He}$ ratio of $\mathrm{He}_{\text {terr }}$ is commonly high $\left(\mathrm{R}_{\text {terr }} / \mathrm{R}_{\mathrm{a}}\right.$ of $\left.0.3-2.0\right)$ suggesting that Española Basin ground water commonly contains mantle-sourced 
He. The ${ }^{3} \mathrm{He} /{ }^{4} \mathrm{He}$ ratio of $\mathrm{He}_{\text {terr }}$ is generally the highest in the western and southern parts of the basin, closest to the western border fault system and the Quaternary to Miocene volcanics of the Jemez Mountains and Cerros del Rio. The occurrence of high ${ }^{3} \mathrm{He} /{ }^{4} \mathrm{He}$ ratios in $\mathrm{He}_{\text {terr }}$ in samples with adjusted ${ }^{14} \mathrm{C}$ ages $>15,000 \mathrm{yr}$ indicates that high ${ }^{3} \mathrm{He} /{ }^{4} \mathrm{He}$ ratios in the Española Basin cannot be attributed mostly to releases of ${ }^{3} \mathrm{H}$ contamination from Los Alamos National Laboratory.

6. Ground-water tracer data collected as part of this study in the Española Basin exhibit coherent trends suggesting that their use as calibration targets in a basin-scale numerical ground-flow model could reduce uncertainty in the location and rate of recharge to the basin.

\section{Acknowledgments}

This study was funded by Los Alamos National Laboratory, the City of Santa Fe, and the U.S. Geological Survey's Rio Grande Basin project. Major logistical assistance was also provided by the New Mexico Environment Department and the U.S. Geological Survey's New Mexico Water Science Center. Many individuals assisted in this study, but those deserving special thanks include Charlie Nylander, Ardyth Simmons, Claudia Borchert, Tien Grauch, Elizabeth Keating, Pat Longmire, Michael Dale, Marcy Hess, Niel Plummer, Kip Solomon, and Jeff Heikoop. I must also thank the multitude of public and private well owners for allowing me to access and sample their wells. This paper was improved considerably after helpful reviews from Niel Plummer and Andy Hunt.

\section{References Cited}

Adams, A.I., Goff, F., and Counce, D., 1995, Chemical and isotopic variations of precipitation in the Los Alamos region, New Mexico: Los Alamos National Laboratory Report LA-12895-MS, 35 p.

Aeschbach-Hertig, W., Peeters, F., Beyerle, U., and Kipfer, R., 1999, Interpretation of dissolved atmospheric noble gases in natural waters: Water Resources Research, v. 35, p. 2,779-2,792.

Aeschbach-Hertig, W., Peeters, F., Beyerle, U., and Kipfer, R., 2000, Paleotemperature reconstruction from noble gases in ground water taking into account equilibration with entrapped air: Nature, v. 405, p. 1,040-1,043.

Anderholm, S.K., 1994, Ground-water recharge near Santa Fe, north-central New Mexico: U.S. Geological Survey WaterResources Investigations Report 94-4078, 68 p.
Anderson, M.P., 2005, Heat as a ground water tracer: Ground Water, v. 43, p. 951-968.

Bayer, R., Schlosser, P., Bönisch, G., Rupp, H., Zaucker, F., and Zimmek, G.,1989, Performance and blank components of a mass spectrometric system for routine measurement of helium isotopes and tritium by the ${ }^{3} \mathrm{He}$ ingrowth method, in Sitzungsberichte der Heidelberger Akademie der Wissenschaften, Mathematisch-naturwissenschaftliche Klasse, vol. 5: Heidelberg, Germany, Springer Verlag, p. 241-279.

Blake, W.D., Goff, F., Adams, A.I., and Counce, D., 1995, Environmental geochemistry for surface and subsurface waters in the Pajarito Plateau and outlying areas, New Mexico: Los Alamos National Laboratory Report LA-12912-MS, 43 p.

Bredehoeft, J.D., and Papadopulos, I.S.,1965, Rates of vertical groundwater movement estimated from the Earth's thermal profile: Water Resources Research, v. 1, no. 2, p. 325-328.

Cavazza, W., 1986, Miocene sediment dispersal in the central Española Basin, Rio Grande rift, New Mexico, U.S.A.: Sedimentary Geology, v. 51, p. 119-135.

Collins, K.A., Simmons, A.M., Robinson, B.A., and Nylander, C.L., 2005, Los Alamos National Laboratory's hydrogeologic studies of the Pajarito Plateau: A synthesis of hydrogeologic workplan activities (1998-2004): Los Alamos National Laboratory Report LA-14263-MS, 276 p.

Cumming, K.A., 1997, Hydrogeochemistry of ground water in Chimayo, New Mexico: Flagstaff, Northern Arizona University, M.S. thesis, 117 p.

Domenico, P.A., and Schwartz, F.A., 1990, Physical and chemical hydrogeology: New York, Wiley, 318 p.

Donahue, D.J., Linick, T.W., and Jull, A.J.T., 1990, Isotoperatio and background corrections for accelerator mass spectrometry radiocarbon measurements: Radiocarbon, v. 32, p. 135-142.

Eichinger, L., 1983, A contribution to the interpretation of ${ }^{14} \mathrm{C}$ groundwater ages considering the example of a partially confined sandstone aquifer: Radiocarbon, v. 25, p. 347-356.

Fontes, J.C., and Garnier, J.M., 1979, Determination of the initial ${ }^{14} \mathrm{C}$ activity of the total dissolved carbon: A review of the existing models and a new approach: Water Resources Research, v. 15, p. 399-413.

Galusha, T., and Blick, J.C., 1971, Stratigraphy of the Santa Fe Group, New Mexico: American Museum of Natural History Bulletin, v. 144, 127 p.

Heaton, T.H.E., and Vogel, J.C., 1981, 'Excess air' in groundwater: Journal of Hydrology, v. 50, p. 201-216. 
Ingerson, E., and Pearson, F.J., Jr., 1964, Estimation of age and rate of motion of groundwater by the ${ }^{14} \mathrm{C}$-method, in Recent researches in the fields of atmosphere, hydrosphere, and nuclear geochemistry, Sugawara Festival volume: Tokyo, Maruzen Co., p. 263-283.

International Atomic Energy Agency, 2006, Isotope hydrology section database [http://isohis.iaea.org, accessed December 2006].

Kalin, R.M., 2000, Radiocarbon dating of groundwater systems, in Cook, P.G., and Herczeg, A.L., eds., Environmental tracers in subsurface hydrology: New York, Kluwer Academic Publishers, p. 111-144.

Keating, E.H., Vesselinov, V.V., Kwicklis, E., and Lu, Z., 2003, Coupling basin- and site-scale inverse models of the Española aquifer: Ground Water, v. 41, p. 200-211.

Kipfer, R., Aeschbach-Hertig, W., Peeters, F., and Stute, M., 2002, Noble gases in lakes and ground waters, in Porcelli, D., Ballentine, C.J., and Wieler, R., eds., Reviews in mineralogy and geochemistry, vol. 47, Noble gases in geochemistry and cosmochemistry: Chantilly, Va., Mineralogical Society of America, p. 615-700.

Koning, D.J., 2002, Preliminary geologic map of the Española 7.5-minute quadrangle: Socorro, New Mexico Bureau of Geology and Mineral Resources, Open-File Geologic Map 54, scale 1:24,000.

Koning, D.J., Smith, G., Lyman, J., and Paul, P., 2004, Lithosome $S$ of the Tesuque Formation: Hydrostratigraphic and tectonic implications of a newly delineated lithosome in the southern Española Basin, New Mexico, in Hudson, M.R., ed., Geologic and hydrogeologic framework of the Española Basin-Proceedings of the 3rd annual Española Basin workshop, Santa Fe, N. Mex., March 2-3, 2004: U.S. Geological Survey Open-File Report 2004-1093, p. 17.

Longmire, P., 1985, A hydrogeochemical study along the valley of the Santa Fe River, Santa Fe and Sandoval Counties, New Mexico: New Mexico Environmental Improvement Division Report EID/GWH-85/3, 35 p.

Longmire, P., Dale, M., Counce, D., Manning, A., Larson, T., Granzow, K., Gray, R., and Newman, B., 2007, Radiogenic and stable isotope and hydrogeochemical investigation of groundwater, Pajarito Plateau and surrounding areas, New Mexico: Los Alamos National Laboratory Report LA-14333, 68 p.

Lucas, L.L., and Unterweger, M.P., 2000, Comprehensive review and critical evaluation of the half-life of tritium: Journal of the National Institute of Standards and Technology, v. 105, p. 541-549.
Mamyrin, B.A., and Tolstikhin, I.N., 1984, Helium isotopes in nature: New York, Elsevier, 273 p.

Manley, K., 1978, Cenozoic geology of the Española Basin, in Hawley, J.W., ed., Guidebook to the Rio Grande rift in New Mexico and Colorado: New Mexico Bureau of Mines and Mineral Resources Circular 163, p. 201-210.

Manley, K., 1979, Stratigraphy and structure of the Española Basin, Rio Grande rift, New Mexico, in Riecker, R.E., ed., Rio Grande rift: Tectonics and magmatism: Washington, D.C., American Geophysical Union, p. 71-86.

Manning, A.H., and Caine, J.S., 2007, Groundwater noble gas, age, and temperature signatures in an alpine watershed-Valuable tools in conceptual model development: Water Resources Research, v. 43, W04404, doi:10.1029/2006WR005349.

Manning, A.H., and Solomon, D.K., 2003, Using noble gases to investigate mountain-front recharge: Journal of Hydrology, v. 275, p. 194-207.

Manning, A.H., and Solomon, D.K., 2004, Constraining mountain-block recharge to the eastern Salt Lake Valley, Utah, with dissolved noble gas and tritium data, in Hogan, J.F., Phillips, F.M., and Scanlon, B.R., eds., Groundwater recharge in a desert environment: Washington, D.C., American Geophysical Union, p. 139-158.

Manning, A.H., and Solomon, D.K., 2005, An integrated environmental tracer approach to characterizing groundwater circulation in a mountain block: Water Resources Research, v. 41, W12412, doi:10.1029/2005WR004178.

Manning, A.H., Solomon, D.K., and Thiros, S.A., 2005, ${ }^{3} \mathrm{H} /{ }^{3} \mathrm{He}$ age data in assessing the susceptibility of wells to contamination: Ground Water, vol. 43, p. 353-367.

Mansure, A.J., and Reiter, M., 1979, A vertical ground-water movement correction for heat flow: Journal of Geophysical Research, v. 84, p. 3,490-3,496.

McAda, D.P., and Wasiolek, M., 1988, Simulation of the regional geohydrology of the Tesuque aquifer system near Santa Fe, New Mexico: U.S. Geological Survey WaterResources Investigations Report 87-4056, 69 p.

Mcquillan, D., Longmire, P., Johnson, P., Kulis, J., Martinez, F., Counce, D., and Keating, E., 2005, Natural uranium in ground water in the Española Basin, in McKinney, K.C., ed., Geologic and hydrogeologic framework of the Española BasinProceedings of the 4th annual Española Basin workshop, Santa Fe, New Mexico, March 1-3, 2005: U.S. Geological Survey Open-File Report 2005-1130, p. 11. 
Mook, W.G., 1972, On the reconstruction of the initial ${ }^{14} \mathrm{C}$ content of groundwater from the chemical and isotopic composition, in Proceedings of the eighth international conference on radiocarbon dating, v. 1: Wellington, New Zealand, Royal Society of New Zealand, p. 342-352.

Mueller, D.K., and Helsel, D.R., 1996, Nurtrients in the nation's waters - Too much of a good thing? U.S. Geological Survey Circular 1136, 23 p.

New Mexico Bureau of Geology and Mineral Resources, 2003, Geologic map of New Mexico: Socorro, New Mexico Bureau of Geology and Mineral Resources, scale 1:500,000.

Phillips, F.M., Peeters, L.A., Tansey, M.K., Davis, S.N., 1986, Paleoclimatic inferences from an isotopic investigation of groundwater in the central San Juan Basin, New Mexico: Quaternary Research, v. 26, p. 179-193.

Plummer, L.N., Bexfield, L.M., Anderholm, S.K., Sanford, W.E., and Busenberg, E., 2004a, Geochemical characterization of ground-water flow in the Santa Fe Group aquifer system, Middle Rio Grande Basin, New Mexico: U.S. Geological Survey Water-Resources Investigations Report 03-4131, 395 p.

Plummer, L.N., Bexfield, L.M., Anderholm, S.K., Sanford, W.E., Busenberg, E., 2004b, Hydrochemical tracers in the Middle Rio Grande Basin, U.S.A., 1. Conceptualization of groundwater flow: Hydrogeology Journal, v. 12, p. 359-388.

Plummer, L.N., Prestemon, E.C., and Parkhurst, D.L., 1994, An interactive code (NETPATH) for modeling net geochemical reactions along a flow path, version 2.0: U.S. Geological Survey Water-Resources Investigations Report 94-4169, $130 \mathrm{p}$.

Purtymun, W.D., 1995, Geologic and hydrologic records of observation wells, test holes, test wells, supply wells, springs and surface water stations in the Los Alamos area: Los Alamos National Laboratory Report LA-12883-MS, $339 \mathrm{p}$.

Purtymun, W.D., Stoker, A.K., and McLin, S.G., Maes, M.N., and Glasco, T.A., 1995, Water supply at Los Alamos during 1993: Los Alamos National Laboratory Report LA-12951-PR, 48 p.

Read, A.S., Koning, D.J., Smith, G.A., Ralser, S., Rogers, J., and Bauer, P.W., 2000, Preliminary geologic map of the Santa Fe 7.5-minute quadrangle: Socorro, New Mexico Bureau of Geology and Mineral Resources, Open-File Geologic Map 32, scale 1:24,000.
Reiter, M., 1999, Hydrogeothermal studies on the southern part of Sandia National Laboratories/Kirtland Air Force Base-Data regarding ground-water flow across the boundary of an intermontane basin, in Haneberg, W.C., ed., Faults and subsurface fluid flow in the shallow crust: Washington, D.C., American Geophysical Union, Geophysical Monograph 113, p. 207-222.

Richardson, S.M., and McSween, H.Y., Jr., 1989, Geochemistry: pathways and processes: Englewood Cliffs, N.J., Prentice Hall, 488 p.

Roether, W., 1967, Estimating the tritium input to groundwater from wine samples: Groundwater and direct runoff contribution to central European surface waters, in Isotopes in hydrology: Vienna, Austria, International Atomic Energy Agency, IAEA-SM-83/7, p. 73-91.

Sanford, W.E., Shropshire, R.G., and Solomon, D.K., 1996, Dissolved gas tracers in groundwater: Simplified injection, sampling, and analysis: Water Resources Research, v. 32, p. 1,635-1,642.

Sawyer, D.A., 2004, Processed Landsat 7 satellite imagery of the Española Basin region, New Mexico: U.S. Geological Survey Open-File Report 2004-1040-A, 1 CD-ROM.

Solomon, D.K., 2000, ${ }^{4} \mathrm{He}$ in groundwater, in Cook, P.G., and Herczeg, A.L., eds., Environmental tracers in subsurface hydrology: New York, Kluwer Academic Publishers, p. $425-439$.

Solomon, D.K., and Cook, P.G., 2000, ${ }^{3} \mathrm{H}$ and ${ }^{3} \mathrm{He}$, in Cook, P.G., and Herczeg, A.L., eds., Environmental tracers in subsurface hydrology: New York, Kluwer Academic Publishers, p. 397-424.

Spiegel, Z., and Baldwin, B., 1963, Geology and water resources of the Santa Fe area, New Mexico: U.S. Geological Survey Water-Supply Paper 1525, 258 p.

Stuiver, M., Reimer, P.J., Bard, E., Beck, J.W., Burr, G.S., Hughen, K.A., Kromer, B., McCormac, G., van der Plicht, J., and Spurk, M., 1998, INTCAL98 radiocarbon age calibration, 24,000-0 cal yr B.P.: Radiocarbon, v. 40, no. 3, p. 1,041-1,083.

Stute, M., and Schlosser, P., 2000, Atmospheric noble gases, in Cook, P.G., and Herczeg, A.L., eds., Environmental tracers in subsurface hydrology: New York, Kluwer Academic Publishers, p. 349-377.

Stute, M., Schlosser, P., Clark, J.F., and Broecker, W.S., 1992, Paleotemperatures in the southwestern United States derived from noble gases in ground water: Science, v. 256, p. 1,000-1,003.

Sweeney, R.E., Grauch, V. J. S., and Phillips, J.D., 2002, Merged digital aeromagnetic data for the Middle Rio Grande and southern Espanola Basins, New Mexico: U.S. Geological Survey Open-File Report 2002-205, 15 p. 
Tamers, M.A., 1975, Validity of radiocarbon dates on groundwater: Geophysical Surveys, v. 2, p. 217-239.

Vesselinov, V.V., and Keating, E.H., 2002, Analysis of capture zones of the Buckman Wellfield and a proposed new horizontal collector well north of the Otowi Bridge: Los Alamos National Laboratory Report LA-UR-02-2750, 59 p.

Vogel, J.C., 1967, Investigation of groundwater flow with radiocarbon, in Isotopes in hydrology: Vienna, Austria, International Atomic Energy Agency, IAEA-SM-83/7, p. 255-368.

Wasiolek, M., 1995, Subsurface recharge to the Tesuque aquifer system from selected drainage basins along the western side of the Sangre de Cristo Mountains near Santa Fe, New Mexico: U.S. Geological Survey Water-Resources Investigations Report 94-4072, 57 p.
Wilkins, D.W., 1986, Geohydrology of the southwest alluvial basins: regional aquifer-systems analysis, parts of Colorado, New Mexico, and Texas: U.S. Geological Survey WaterResources Investigations Report 84-4224, 61 p.

Wilson, J.L., and Guan, H., 2004, Mountain-block hydrology and mountain-front recharge, in Hogan, J.F., Phillips, F.M., and Scanlon, B.R., eds., Groundwater recharge in a desert environment: Washington, D.C., American Geophysical Union, p. 113-137.

Zuber, A., Weise, S.M., Osenbruck, K. Grabczak, J., and Ciezkowski, W., 1995, Age and recharge area of thermal waters in Ladek Spa (Sudeten, Poland) deduced from environmental isotope and noble gas data: Journal of Hydrology, v. 167, p. 327-349.

Publishing support provided by:

Denver Publishing Service Center, Denver, Colorado

Manuscript approved for publication, October 16, 2008

Edited by Tom Judkins

Graphics and layout by Joy Monson

For more information concerning this publication, contact:

Team Chief Scientist, USGS Crustal Imaging and Characterization

Box 25046, Mail Stop 964

Denver, C0 80225

(303) 236-1312

Or visit the Crustal Imaging and Characterization Team Web site at:

http://crustal.usgs.gov/

This publication is available online at:

http://pubs.usgs.gov/sir/2008/5200/ 
